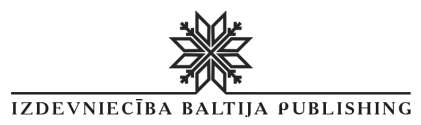

\title{
DEVELOPMENT TRENDS IN LEGAL SCIENCE AND PRACTICE: THE EXPERIENCE OF COUNTRIES OF EASTERN EUROPE AND PROSPECTS OF UKRAINE
}

\author{
Monograph
}

Riga, Latvia 2018 
UDC 34(4)

De 933

Title: Development trends in legal science and practice: the experience of countries of Eastern Europe and prospects of Ukraine

Subtitle: Monograph

Scientific editor and

project director: Anita Jankovska

Authors: Bondar Valeriia, Hnidenko Viktoriia, Kaplina Halyna, Guyvan Oksana, Sergienko Valeriy, Dolynska Mariia, Dudka Larisa, Kuzmenko Sergey, Nadezhdenko Alina, Lozytska Iryna, Bashtannyk Vitalii, Murzina Tetiana, Pakhomova Tetiana, Nesprava Mykola, Riabchenko Yaroslava, Zuj Valentina, Tupitska Yevgenia, Tymoshevska Iryna, Shevchenko Liudmyla

Publisher: SIA "Izdevnieciba "Baltija Publishing", Valdeku iela 62-156, Riga, LV-1058

Available from: http://www.baltijapublishing.lv/index.php/legal-science

Year of issue: 2018

All rights reserved. No part of this book may be reprinted or reproduced or utilized in any form or by any electronic, mechanical, or other means, now known or hereafter invented, including photocopying and recording, or in any information storage or retrieval system, without permission in writing from the publisher and autor.

Development trends in legal science and practice: the experience of countries of Eastern Europe and prospects of Ukraine: monograph / edited by authors. - Riga, Latvia : "Baltija Publishing", 2018. $-244 \mathrm{p}$

ISBN: 978-9934-571-29-9

DOI: https://doi.org/10.30525/978-9934-571-29-9

The monograph studies theoretical and practical development trends of legal science and practice, taking into account the experience of countries of Eastern Europe and prospects of Ukraine. General issues of history and theory of state and law, constitutional, administrative law and procedure, as well as provisions of criminal executive law, criminology, forensic enquiry and so on, are considered. The publication is designed for scientists, lecturers, postgraduate students, and students of legal educational establishments, lawyers, judges, workers of law enforcement agencies, as well as for the general reader.

C) Publishing House "Baltija Publishing", 2018

(C) Authors of the articles, 2018 


\section{Table of Contents}

\section{Bondar Valeriia}

THE CERTAIN ISSUES OF THE ADMINISTRATIVE

AND LEGAL REGULATION OF THE ACTIVITY

OF THE NATIONAL POLICE OF UKRAINE.

Hnidenko Viktoriia, Kaplina Halyna

ANALYSIS OF TRENDS FOR DEVELOPMENT

OF DISTANTLY EMPLOYMENT IN UKRAINE.

Guyvan Oksana, Sergienko Valeriy

CIVIL-LAW PROTECTION OF SUBJECTIVE RIGHTS

IN THE INFORMATION SPHERE.

\section{Dolynska Mariia}

THEORETICAL-LEGAL AND APPLIED ASPECTS

OF THE NOTARIAL PROCEDURE CONCERNING

THE CERTIFICATION OF WILLS

\section{Dudka Larisa}

THE CHURCH AS AN INSTITUTION OF CIVIL SOCIETY:

THE EXPERIENCE OF BECOMING IN MODERN UKRAINE.

Kuzmenko Sergey, Nadezhdenko Alina

LEGAL REGIME FOR THE PROTECTION OF COMMERCIAL

CONFIDENTIALITY IN THE EU AND UKRAINE

\section{Lozytska Iryna, Bashtannyk Vitalii}

THEORETICAL AND METHODOLOGICAL BASIS

OF IMPLEMENTATION OF THE FOREIGN EXPERIENCE

OF ADMINISTRATIVE REGULATION IN THE SYSTEM

OF PUBLIC ADMINISTRATION

\section{Murzina Tetiana, Pakhomova Tetiana}

THE REFORM OF THE LOCAL SELF-GOVERNMENT

OF THE CZECH REPUBLIC AND SLOVENIA.

EXPERIENCE FOR UKRAINE.

\section{Nesprava Mykola}

THE PROBLEM OF CORRELATIONSHIP BETWEEN EUROPEAN PRINCIPLES OF LAW AND CHISTIAN VALUES IN THE CONTEXT OF CURRENT CHALLENGES. 
Riabchenko Yaroslava, Zuj Valentina

JURISDICTIONAL POWERS OF PUBLIC ADMINISTRATION AUTHORITIES

IN UKRAINE AND FOREIGN COUNTRIES: PROBLEMS OF EXECUTION

Tupitska Yevgenia, Tymoshevska Iryna

HISTORY OF CREDIT LEGAL RELATIONSHIP IN UKRAINE

AND ITS REGULATION IN FOREIGN JURISDICTIONS

Shevchenko Liudmyla

LAW \& MANAGEMENT: A NEW APPROACH FOR SCIENTIFIC

RESEARCHES AND THE MANAGERIAL PRACTICE 


\section{THE CERTAIN ISSUES OF THE ADMINISTRATIVE \\ AND LEGAL REGULATION OF THE ACTIVITY \\ OF THE NATIONAL POLICE OF UKRAINE}

\section{Bondar Valeriia ${ }^{1}$}

DOI: http://dx.doi.org/10.30525/978-9934-571-29-9_1

Abstract. In the article the research of the specific problems of administrative and legal regulation of the activity of theNational police of Ukraine is conducted. The purpose of the scientific article is to carry out the analysis of certain problematic issues of the administrative and the legal regulation of the activity of the National Police of Ukraine. A scientific study of the administrative and legal regulation of the activity of the National Police was carried out in the works of V.M. Bevzenko, P.D. Bilenchuk, N.P. Bortnik, V.A. Glukhoveria, D.O. Denisyuk, S.S. Yesimov, V.V. Garbuzov, O.V. Kuzmenko, V.I. Kurilo, M.N. Kurko, D.M. Lastovich, I.V. Filshtein, A.A. Yarmoluk and others. However, today, the certain issues concerning the administrative and legal regulation of the activity of the National Police are of a scientific interest and require further research. In order to achieve the purpose of the scientific article, taking into account the object and the subject of the research, the general scientific and special methods were used in the article, in particular: dialectical method as a general method of scientific knowledge and historical and legal method allowed to consider all the issues of the topic in dynamics, to discover their interconnection and interdependence, to explore the ways of the developing of the legislation, that regulates the activity of the National Police of Ukraine, the comparative legal method, the logical-semantic method, the formal-logical method and the dogmatic (formal-legal) method. The recent research and publications on the subject is determined. The analysis of the legislation thatregulates the activity of the National Police of Ukraine is performed. The different approaches to understanding of the administrative and legalregulation are conducted. The definition of the administrative and legalregulation of the activity of the National police of Ukraine is provided. The analysis of the

\footnotetext{
${ }^{1}$ Candidate of Law Sciences, Associate Professor of Department of General Law and Social and Humanitarian Disciplines, Kherson Faculty of the Odessa State University of Internal Affairs, Ukraine

(C) Bondar Valeriia
} 


\section{Bondar Valeriia}

objectives and the principles of the activity of the National police of Ukraine is carried out. The analysis of the regulations not of the highest legal force is carried out too. In the article also the list of the legal acts that have been adopted by the time police work is provided. The research of the court practice and the lawyer practice is also given. It is concluded that the list of the valid legal acts that have been adopted by the time police work require reviewing and amending with current requirements, trends of the legal regulation and in order to bring them into line with the changes in the legislation and the adoption of the Law of Ukraine "About the National police". Some grounded recommendations for improving the Law of Ukraine "About the National police" are proposed. The author's version of the Article 40 of the Law of Ukraine "About the National police" is proposed.

\section{Introduction}

Formation of Ukraine as a legal, democratic and social state requires the providing of proper law and order, the achievement of which is impossible without the improvement of the legal framework that regulate the activity of the state authorities. First of all it concerns the activity of the bodies of internal affairs of Ukraine.

It should be noted that an important step in the reforming of the activity of the bodies of internal affairs of Ukraine aimed at raising of the level of law and order in the state, became the liquidation of the militia and the introduction of the National Police, that as correctly it is stated in the literature, from the tool of "force" support of the political regime should become a social institution, which guarantees the effective protection of the individuals, society and state from criminal encroachments [1].

As of today, the legislative basis of the newly created body is, firstly, insufficient, and secondly, it does not fully correspond to the realities of the present.

On July 2, 2015, the Verkhovna Rada of Ukraine adopted the Law of Ukraine № 580-VIII “About the National Police” (hereinafter - the Law). According to the Article 1 of the Law, the National Police of Ukraine is a central executive authority body that serves the society by the ensuring of the protection of human rights and freedoms, combating of crime, maintaining public security and order. In exercising of its powers, the police is guided by the following principles: the rule of law, the respect for human rights and freedoms, legality, openness and transparency, political 


\section{The certain issues of the administrative and legal regulation of the activity...}

neutrality, interaction with the population on the basis of the partnership, continuity.

At the same time, according to the Article 2 of the Law, police tasks are to provide police services in the following areas: 1) the ensuring of public safety and order; 2) the protection of human rights and freedoms, as well as the interests of society and the state; 3 ) combating and counteraction of crime; 4) provision of assistance services according to the law to persons who require such assistance because of personal, economic, social reasons or as a result of emergencies [2].

In addition, it is well-known that the successful exercise of the powers of any government body, including the National Police, and the compliance with its principles of activity, not least depends on the quality of legal acts that regulate its activity. It should be noted that certain inaccuracies, ambiguous interpretations, misunderstandings in the content of the legal acts, reduce their effectiveness.

Unfortunately, some rules of the Law are set out in such a way as to exclude the possibility of the effective administrative and legal regulation of the activity of the National Police, the ensuring of the compliance with the principles and implementation of the tasks of the latter.

Therefore, the issue of improving the legal acts that regulate the activity of the National Police, the bringing them in conformity with international standards is of high relevance.

\section{The concept of the administrative and legal regulation}

In addition, it should be noted that the legal regulation of the activity of public authorities is a significant place in the process of the building of Ukraine as a law-governed state. Therefore, it is obvious that the proper and effective execution of their functions and powers by the state authorities is impossible without the administrative and legal regulation, which requires further research and improvement.

At the same time, in the context of our study, the theoretical definition of the concept and content of the administrative and legal regulation of the activity of the National Police of Ukraine becomes relevant, for which it is first of all to apply to the doctrinal provisions of the administrative law.

Thus, in the theory of law under the legal regulation is understood as the purposeful influence of the legal norms that are adopted by the state and are the appropriate administrative means to ensure the rights and legitimate inter- 


\section{Bondar Valeriia}

ests of individuals and legal entities and the state in social relations in order to subordinate their legally established law and order, as well as with the protection and development in the interests of society and the state [3, p. 51].

In turn, in the legal encyclopedia the legal regulation is defined as the power of the state that is exercised by the state through all legal means to influence the social relations with a purpose to their ordering, consolidation, protection and development, as well as the influence on the behavior and consciousness of citizens through the declaration of their rights and responsibilities, the establishment of certain permissions and prohibitions, the approval of certain legal acts, etc. [4, p. 369].

At the same time, the administrative-legal regulation is understood as the purposeful influence of the norms of the administrative law on social relations in order to ensure the rights, freedoms and public legitimate interests of individuals and legal entities, the normal functioning of civil society and the state with the help of administrative and legal means.

Also the researchers-administrators distinguish the main features of the administrative-legal regulation: the purposeful nature, the presence of a certain subject and the scope of legal influence, the focus on the rights, freedoms and public interests of individuals and legal entities, organizational and orderly nature, the presence of certain stages that provide for the regulation of social relations, provision on the basis of the implementation of the administrative-legal method [5, p. 241-242].

There ia a similar view of T.S. Goncharuk, who considers the following: "Mechanism of the administrative-legal regulation - it is a system of the administrative and legal means (elements), through which the legal regulation (streamlining) of public relations in the field of public administration is carried out" $[6$, p. 23]. It should also be noted that taking into account the subject of the legal regulation of the administrative law, most scholars believe that the structure of the mechanism of the administrative-legal regulation consists of administrative-legal rules, acts of interpretation and acts of implementation of administrative-legal rules, administrative-legal relations.

It should also be noted that the vast majority of the blighty administrators and scholars point out that the subject of the legal regulation of the administrative law is social relations of managerial nature. At the same time, it should be emphasized that such leading administrators as V.K. Shkarupa and T.O. Kolomoets, rightly complement that the administrative law is intended 
to regulate relations in the sphere of the providing by the executive bodies and local self-government bodies of the implementation of the protection of rights, freedoms and legitimate interests of individuals and legal entities [7].

In the context of the study it should be noted that the above-mentioned scholars have developed a general doctrine of administrative law, formed by V.B. Averyanov, who believed that the basis of the new administrative-legal doctrine should be the human-centered ideology. According to it, the state should fully satisfy and defend the interests of citizens, that is, to act for the benefit of a man - through the comprehensive provision of the priority of his/her rights, the freedoms of legitimate interests in the field of public administration [8, p. 7].

Thus, taking into account the foregoing, we can conclude that the administrative and legal regulation is primarily intended to ensure the rights, freedoms and legitimate interests of a man and a citizen, as well as a society and the state as a whole.

\section{Law regulation of the activity of the National Police}

At the same time, it is necessary to note that in the scientific literature the analysis of the administrative and legal regulation of various state authorities, including the bodies of internal affairs, has been covered for quite some time.

Thus, the legal regulation of the bodies of the internal affairs is understood as the effective state influence on these bodies for the purpose of their organization in accordance with the tasks of society and the state in the interests of the protecting of human rights and citizens, which is ensured by a certain system of regulatory regulation $[9$, p. 45].

In this issue the opinion of D.V. Vlasenko is efficient. He claims that the administrative and legal regulation of the activity of the National Police should be considered as a process of streamlining by means of the administrative law, by authorized agents of the relevant social relations that arise in the connection with the organization and operation of the National Police [10, p. 126].

As we see, there are no significant differences between the abovementioned definitions of scientists regarding the administrative-legal regulation. All of them distinguish in the definition of the administrative law two obligatory elements: the power influence on social relations and the availability of certain legal means by which this influence is exercised. 


\section{Bondar Valeriia}

Thus, from the analysis of the above-mentioned definitions of the administrative-legal regulation, we can conclude that its mandatory element is the availability of the certain legal means, or rather, the administrative-legal norms through which the power influence on social relations is exercised.

The view of S.V. Kivalov is similar. He notes that the mandatory element of the mechanism of the administrative and legal regulation is administrative law rules as some rules of conduct, that are established or authorized by the state and are obligatory for implementation [11, p. 14].

At the same time, in the context of our study, it should be noted that the significance of the legal regulation is mediated by the object of such regulation, that is, the environment in which and under the influence of which law affects on social relations.

In this regard T. Takhovych claims that the sphere of the legal regulation is those social relations (economic, political, cultural, national, religious, etc.) that require legal influence. These relations that constitute the subject of legal regulation, are volitional, objectively need influence from the state and have a clearly defined content [12, p. 297].

Thus, taking into account the foregoing, in order to clarify the essence of the administrative and legal regulation of the activity of the National Police of Ukraine it is necessary to find out what should be understood under the notion of "the activity of the National Police of Ukraine", which is the subject of the said regulation.

At the same time, in order to determine the administrative and legal regulation of the activity of the National Police of Ukraine as an object of the administrative and legal regulation, it is necessary at first to reveal the content of such components of the concept as "the activity" and "the National Police of Ukraine".

It should be noted that the notion of the National Police of Ukraine is provided by the legislator in the Article 1 of Law of Ukraine № 580-VIII "About the National Police" and has already been mentioned earlier in our study. At the same time, it is necessary to apply to scientific literature to find out the meaning of the term "activity", which is an integral part of the concept "activity of the National Police of Ukraine".

So, according to the Academic Explanatory Dictionary of the Ukrainian language, activity means: 1. Application of one's work to something; 2. Functioning, action of organs of a living organism; 3. Detection of power, energy of something [13]. 


\section{The certain issues of the administrative and legal regulation of the activity...}

In the scientific literature, the category of "activity" is also defined in different ways, in particular: as the conscious actions of a person, that are accompanied by reflection; the process of the implementation of the norms in the field of labor relations [14]; as a process of creating by the subject of conditions for its existence and development or their using for transforming the environment in accordance with the goals and objectives of the organization in which it works [15, p. 234]; as a manifestation of the abilities of the individual during the practical using of his intellectual capital for the purposeful change of certain economic and social objects [16, p. 83]. In this case, the activity is connected with the activity of the person (subject). It is the internal (psychic) and external (physical) activity of the person (subject), that is regulated by the realized purpose [17, p. 43], is the basis of the activity, its essence.

Thus, we can conclude that the category of "activity" is disclosed primarily because of the term "actions", that is why the activity of the National Police of Ukraine from the legal point of view can be considered through a set of the legal acts that are carried out by certain subjects.

Taking into account all the above and the fact that the content of the administrative-legal regulation is characterized by the presence of a specific imperative-power method, in order to clarify the content of the administrative and legal regulation of the activity of the National police of Ukraine as the object of the administrative and legal regulation it is necessary to to uncover its features.

So, the analysis of the legislation and the scientific literature allows us to state that the features of the administrative and legal regulation of the activity of the National police of Ukraine are:

- the administrative and legal regulation of the activity of the National police of Ukraine has a purposeful character, because such regulation is directed at the regulation of certain social relations, namely those that arise from the activity of the National Police of Ukraine;

- the administrative and legal regulation of the activity of the National police of Ukraine is aimed primarily at ensuring constitutional rights, freedoms and public interests of a person and a citizen;

- the administrative and legal regulation of the activity of the National police of Ukraine is carried out on the basis of norms of administrative law;

- the administrative and legal regulation of the activity of the National police of Ukraine is carried out with the help of the means and methods of 


\section{Bondar Valeriia}

the administrative-legal regulation, which are used by the subjects of the public administration in the field of the administrative and legal regulation of the activity of the National Police of Ukraine;

- the administrative and legal regulation of the activity of the National police of Ukraine is accompanied by the emergence of the subjective public rights and obligations among the subjects of legal relations that arise in the course of the activity of the National Police of Ukraine.

Thus, we can state that under the administrative legal regulation of the activity of the National Police it is necessary to understand the system of the administrative and legal means that are used by the subjects of the public administration, which within their competence are called to regulate the activity of the National Police on the basis of the administrative law norms, that are aimed at the exercise of influence on social relations in order to ensure the constitutional rights and legitimate interests of man and citizen.

Consequently, taking into account the foregoing, in order to identify the problematic issues in the administrative and legal regulation of the activity of the National Police, it is necessary to analyze some of the administrative and legal norms governing the activity of the latter.

\section{The problems of the legislative support of police activity}

Problems of the legislative provision of police activity can be considered from the point of view of the existence of the legal basis of the police activity and the availability of gaps and collisions in certain legal acts.

So, speaking about the normative acts that concern the activity of the police itself, it should be noted that there are not many normative acts at the moment.

The main legal acts that regulate the activity of the police are the Law of Ukraine "About the National police" from 2 July, 2015 № 580-VIII, the Posture about the National Police, approved by the Resolution of the Cabinet of Ministers of Ukraine from 28 October, 2015 № 877, the Posture about the patrol service of the Ministry of the Internal Affairs, approved by the Order of the Ministry of the Internal Affairs of Ukraine dated 02.07.2015 № 796, the Resolution of the Cabinet of the Ministers of Ukraine dated September 30, 2015, № 823 “About the Uniformity of the Police”, the Instruction of the registration of the police materials on administrative violations in the field of the road safety, recorded not in the automatic mode, approved by the Order of the Ministry of the Internal Affairs of Ukraine of 07.11.2015 № 1395, the 
Instruction about the procedure of detecting of the drivers of vehicles of signs of alcohol, narcotic or other intoxication or staying under the influence of drugs that reduce the attention and the speed of reaction, approved by the joint Order of the Ministry of the Internal Affairs of Ukraine and the Ministry of Health of Ukraine from 09.11.2015 № 1452/735, the Resolution of the Cabinet of the Ministers of Ukraine dated 17.12.2008 № 1103 “About the approval of the Procedure of the referral of drivers of vehicles for inspection to detect the condition of alcohol, drugs or other drunkenness or stay under the influence of medicinal products that reduce the attention and speed of reaction, and the conduct of such review", the Order of the Ministry of the Internal Affairs of Ukraine dated 23.12.2015 № 1614 "About the organization of the issuing of special tokens by the police".

Along with this, the National Police is guided in its activities by normative acts that were adopted during the operation of the militia and regulated its activity, that adversely affects to the activity of the police today.

These acts include the Law of Ukraine of June 30, 1993, №. 3353-XII "About the Road Traffic", the Order of the Ministry of the Internal Affairs of Ukraine dated December 19, 2012 № 1176 "About the Approval of the Instruction of the organization of the work of the criminal department militia of children's affairs, the Disciplinary Statute of the internal affairs institutions of Ukraine from 22.02.2006 № 3460-IV, the Resolution of the Cabinet of the Ministers of Ukraine of 10.10.2001 № 1306 “About the Rules of the Road", a letter of the Ministry of the Internal Affairs of Ukraine dated November 25, 2009 № K-4836, etc.

It should be noted that this is not an exhaustive list of the normative legal acts that are referenced by the staff of the National Police in carrying out their activity, however, the said legal acts regulate the procedure for the activity of the officers of militia. In accordance with paragraph 5 of the Section XI of the Law "The final and transitional provisions" of the Law of Ukraine "About the Militia" was declared invalid. Therefore, the reference to these acts is illegal, because in accordance with the Article 19 of the Constitution of Ukraine, bodies of state power and bodies of local self-government, their officials are obliged to act only on the basis, within the limits of authority and in the manner that is provided by the Constitution of Ukraine and the laws of Ukraine.

The National Police is a state authority and, accordingly, its discretionary powers and the manner in which they are carried out should be exclusively 


\section{Bondar Valeriia}

within the principle of lawfulness, with the application of the norms that are legally valid during the process of the bringing to the legal liability of the legal entities and the individuals. Failure to adhere to this principle leads to the negative consequences in the form of the destruction of the legal basis for the functioning of the mechanism of state authorities, as separate units.

Consequently, taking into account the foregoing, we can conclude that the normative acts that were adopted during the operation of the militia in order to regulate the activity of the latter, which are still in force, need to be revised and amended to take into account modern requirements, trends of legal regulation and in order to bring them in line with changes in the legislation and the adoption of the Law of Ukraine "About the National Police".

\section{The problems of legal regulation of the activity of the National Police}

In the context of our study it should also be noted that in the area of the administrative and legal regulation of the activity of the National Police there are still some problematic issues.

Thus, the Article 40 of the Law of Ukraine "About the National Police" contains provisions that the police may, for the purpose of the ensuring of public safety and order in order to prevent, detect or record offenses, protect public safety and property, ensure the safety of persons and ensure the observance of traffic rules, may fix to uniforms, office transport facilities, mount / place on the external perimeter of roads and buildings automatic photo and video equipment, and also use information that was obtained from automatic photo and video equipment that residing in someone else's possession [2].

The said right derives from the provisions of the Article 9 of the Law of Ukraine "About the National Police", which stipulates that the police is acting on the principles of openness and transparency.

As we see, the norm that is analized in the study is not imperative, since it does not oblige the National Police staff of Ukraine to use with their powers technical devices and technical means that have photography and motion pictures functions, video recording, or photo means in each case when staff is exercising their authority.

We believe that the wording of the article 40 of the Law of Ukraine "About the National Police" in this version does not contribute to the achievement of the objectives of the police, the effective implementation 
of the police officers of their powers, as well as the protection of the police themselves.

This is primarily due to the fact that one of the aspects of the implementation of the tasks of the National Police of Ukraine is the proceedings in cases of the administrative offenses that are committed by the police officers of Ukraine in order to timely, comprehensively, fully and objectively clarify the circumstances of each case, resolve it in strict accordance with the law, the ensuring of the implementation of the issued resolution, as well as the identifying of the causes and the conditions that conducive to the administrative offenses, the preventing of the offenses, the educating of the citizens in the spirit of the observance of laws, and strengthening the rule of law.

The administrative offense (misdemeanor) is meaned as the unlawful, guilty (intentional or negligent) act or inaction that infringes to public order, property, rights and freedoms of citizens, to the established procedure of management and for which the law provides for the administrative liability (the Article 9 of the Code about Administrative Offenses) and therefore the proof of the guilt is one of the circumstances to be proved in cases of administrative offenses.

Yes, according to the Article 280 of the Code of Ukraine About the Administrative Offenses the body (the official), including the staff of the National Police during the considering a case about an administrative offense, are obliged to find out: whether an administrative offense was committed, whether this person is guilty of his commission, whether it is subject to administrative responsibility, whether there are the circumstances mitigating and aggravating the responsibility, whether material damage was caused, whether there are grounds for the transfer of material about an administrative offense to the consideration of a public organization, a labor collective, as well as to find out other circumstances that have a meaning for the proper resolution of the case [18].

In addition, in the process of the proceedings about administrative offenses that is committed by the National Police officers, the latter apply a variety of measures to secure proceedings in cases of administrative offenses: administrative detention, personal review and review of the things, seizure of the things and documents, temporary withdrawal of a driver's license, temporary detention of vehicles, removal of persons from the management of vehicles, river and small size vehicles and inspection 


\section{Bondar Valeriia}

of the state of alcohol, narcotic or other intoxication, or due to exposure to medicines that reduce their attention and reaction rate.

The above circumstances, as well as the legality of the application of measures to ensure the conduct of cases about the administrative offenses are established by means of evidence.

According to the Article 251 of the Code of Ukraine about administrative offenses the evidence in an administrative offense case is any factual data on the basis of which the authority (the official) determines in the statutory procedure the presence or absence of an administrative offense, the guilt of the person in his commission and other circumstances of the importance for the correct solution to a case [18].

These data are established by the protocol about the administrative offense, by the explanations of the person who is being brought to the administrative liability, victims, witnesses, the expert opinion, the material evidence, the testimonies of the technical devices and technical means, which have functions of photo and video shooting, video recording, including those that are used by the person who is the subject of the administrative liability, or witnesses, and also those/which who are working in an automatic mode, or means of photographing and filming, video recording, including those that are used by the person who is the subject of the administrative liability, or witnesses, and also those/which who are working in an automatic mode, which are used when the supervising for the observance of the rules, norms and standards concerning road traffic safety, by the protocol on the removal of things and documents, as well as other documents.

It should be noted that the duty to collect the evidence relies on the persons that are authorized to compile the protocols about the administrative offenses, that are determined in the Article 255 of the Code of Ukraine about administrative offenses.

At the same time, the body (the official) evaluates the evidence based on its internal conviction, based on a comprehensive, complete and objective study of all the circumstances of the case in their totality, guided by the law and legal awareness [18].

In addition, it should also be noted that the analysis of the judicial practice allows us to state that the legality of measures of the ensuring of the proceeding of the cases in administrative offenses, as well as the imposition of administrative penalties at the place of committing of the administrative offense or in court is often contested in the court. 


\section{The certain issues of the administrative and legal regulation of the activity...}

Therefore, the presence of photographic and filming, video recording at the judicial appeal of the decisions of competent bodies to bring to the administrative liability and to apply some measures to ensure the conduct of cases about administrative offenses, would be crucial.

In our view, in order to ensure the rule of law, security and law order, the protection of human rights and freedoms, the interests of society and the state, as well as the fight against crime, it is necessary to oblige the employees of the National Police of Ukraine to use technical devices and technical means in each case, when they are exercising their authority, that have the functions of photography and film, video recording, or photographic and cinematographic, video recording.

Thus, in order to improve the administrative legislation and to eliminate existing legislative gaps, we propose the part 1 of the Article 40 of the Law of Ukraine "About National Police" to spell out in such edition:

The Part 1 The police to ensure public security and order with a purpose of:

1) prevention, detection or recording of an offense;

2) protection of public safety and property;

3) security of persons and their own security;

4) ensuring of compliance with the rules of the road:

- is obliged to fix on the uniform clothes, the service vehicles, the automatic photo and video equipment, and also to use the information received from the automatic photo and video equipment, which is in someone else's possession;

- has the right to mount / place on the external perimeter of the roads and buildings automatic photo and video equipment.

The Part 2 The information about mounted / placed automatic photographic equipment and video equipment must be placed in a prominent place.

3. The persons must be notified by a police officer of the using of the automatic photo and video equipment.

\section{Conclusions}

Summing up the above, we can conclude the following:

1) the administrative and legal regulation is primarily intended to ensure the rights, freedoms and legitimate interests of a man and a citizen, as well as a society and the state as a whole;

2) the administrative legal regulation of the activity of the National Police it is necessary to understand the system of the administrative and 


\section{Bondar Valeriia}

legal means that are used by the subjects of the public administration, which within their competence are called to regulate the activity of the National Police on the basis of the administrative law norms, that are aimed at the exercise of influence on social relations in order to ensure the constitutional rights and legitimate interests of man and citizen;

3 ) the normative acts that were adopted during the operation of the militia in order to regulate the activity of the latter, which are still in force, need to be revised and amended to take into account modern requirements, trends of legal regulation and in order to bring them in line with changes in the legislation and the adoption of the Law of Ukraine "About the National Police".

4) the Law of Ukraine "About the National Police" requires the improvement in the term of consolidation of the imperative law rules that relate the using of technical equipment and equipment by employees of the National Police with functions of photography and motion pictures, video recording, or photographic and cinematographic, video recording.

\section{References:}

1. Lipkan V.A. (2007) Problemi i shlyahi udoskonalennya pravovogo zabezpechennya upravlinnya $\mathrm{v}$ organah vnutrishnih sprav [The problems and ways of improving the legal support of the governance in the internal affairs bodies]. - [Electronic resource]. Teoriya upravlinnya $\mathrm{v}$ organah vnutrishnih sprav (electronic textbook). Available at: http://semestr.com.ua/book 378 glava_155_3.\%C2\%A0\%C2\%A0\%C2\%A0\%C2\%A0_Problemi_\%D1\%96_shljakh. html (accessed 10 March 2018).

2. The Law of Ukraine dated July 2, 2015 № 580-VIII “About the National Police" [Electronic resource]. Available at: http://zakon2.rada.gov.ua/laws/show/58019/ page?text $=\% \mathrm{EF} \% \mathrm{~F} 0 \% \mathrm{E} 0 \% \mathrm{E} 2 \% \mathrm{EE} \% \mathrm{ED} \% \mathrm{E} 0$ (accessed 10 March 2018 ).

3. Terymetsky V. I. (2012) Ponyattya administrativno-pravovogo regulyuvannya u sferi opodatkuvannya [The concept of the administrative-legal regulation in the field of taxation]. State and regions. The set "Law", vol. 1, 35, pp. 50-54.

4. Gizhevsky V.K., Golovchenko V.V., Kovalsky V.S. (2002) Populyarna yuridichna enciklopediya [The Popular Law Encyclopedia]. Kyiv: Yurincom Inter.

5. Galunko V.V., Olefir V.I., Pikhtin M.P. (2011) Administrativne pravo Ukraïni : navchal'nij posibnik u 2-h tomah [The administrative law of Ukraine: a textbook in 2 volumes]. Kherson: HMT.

6. Goncharuk S.T. (2000) Administrativne pravo Ukraïni. Zagal'na ta Osobliva chastini : na- vch. posib. na dopomogu sluhacham, shcho zdayut' derzh. ta potochni ispiti z adm. prava [The Administrative Law of Ukraine. General and Special Parts: tutorial to help students handing over the state and current exams with admins. Law]. Kyiv: Nat. acad. Of Internal Affairs; National acad. of Supervision. 


\section{The certain issues of the administrative and legal regulation of the activity...}

7. Shkarupa V.K., Kolomoets T.O., Gulevskaya G.Y. (2007) Administrativne pravo Ukraïni : navchal'nij posibnik [The Administrative Law of Ukraine: textbook]. Kyiv: Truth.

8. Averyanov V.B., Derets V.A., Shkolik A.M. (2007) Publichne upravlinnya: €vropejs'ki standarti, dosvid ta administrativne pravo [The Public administration: European standards, experience and administrative law]. Kyiv: Justinian.

9. Petrova I.P. (2004) Normativno-pravove regulyuvannya organizaciï i diyal'nosti miliciï Ukraïni [The normative and legal regulation of the organization and activity of the militia of Ukraine] (PhD Thesis), Irpen: National Academy of State Tax Service of Ukraine.

10. Vlasenko D.V. (2016) Suchasnij stan administrativno-pravovogo regulyuvannya diyal'nosti Nacional'noï policiï Ukraïni [Modern state of the administrative-legal regulation of the activity of the National Police of Ukraine]. Law and Society, vol. 4, 2, pp. 125-130.

11. Kivalov S.V. (2013) Administrativne pravo Ukraïni : uchebnik [The Administrative law of Ukraine: textbook]. Odessa : Yurid. 1-ra.

12. Zaychuk O.V., Zayets A.P., Zhuravsky V.S. (2006) Teoriya derzhavi i prava. Akademichnij kurs [The Theory of state and law. Academic course]. Kyiv:Yurinkom Inter.

13. The Dictionary of the Ukrainian language. Academic Explanatory Dictionary (1970-1980) [Electronic resource]. Available at: http://sum.in.ua/s/dijaljnistj.

14. Kolpakov V. K. (2002) Yak prijmati rishennya? [How do we make decisions?]. Staff, vol. 8, pp. 54-61.

15. Belyavsky N.P., Veselko S.E., Roish P. (2006) Upravlinnya personalom: navchal. posibnik [Personnel Management: Study. Allowance]. Minsk: IP "Ecoperspectiva".

16. Khokhlov B. (2005) Naemnye rabotniki i korporativnoe upravlenie [Employers and corporate management]. Man and labor, vol. 33, pp. 82-83.

17. Yesinova N.I. (2003) Ekonomika truda i social'no-trudovye otnosheniya: Ucheb. Posobie [The Economics of Labor and Social-Labor Relations: Textbook]. Kyiv: Kondar.

18. The Code of Ukraine about Administrative Offenses dated December 07, 1984 № 8073-X [Electronic resource]. Available at: http://zakon2.rada.gov.ua/laws/ show/80731-10/paran3896\#n3896 (accessed 10 March 2018). 


\section{ANALYSIS OF TRENDS FOR DEVELOPMENT OF DISTANTLY EMPLOYMENT IN UKRAINE}

\section{АНАЛІЗ ТЕНДЕНЦІЙ РОЗВИТКУ ВІДДАЛЕНОЇ ЗАЙНЯТОСТІ В УКРАЇНІ}

\section{Hnidenko Viktoriia ${ }^{1}$ \\ Kaplina Halyna ${ }^{2}$ \\ DOI: http://dx.doi.org/10.30525/978-9934-571-29-9_2}

Abstract. The essence of globalization in the field of labor relations is explored. The mechanism of influence of the global informational environment on the national labor market is described. The subject of this study is labor lawsuits, which arise from the subjects of labor law in the exercise of their right to work through forms of remote employment and with the growth of the Internet. The purpose of the research aimed at analyzing existing and developing new labor-law approaches to the regulation of non-traditional, modern forms of employment and ways to realize the right to work in modern society is formulated. In accordance with the stated goal, the task of determining the factors influencing the development of the typology of non-standard employment, clarification of the concept of "digitalization" and analysis of the provisions of the Concept of the development of the digital economy of Ukraine will be addressed. It is indicated that an important direction of the research is also the justification for the need for a meaningful revision of the concepts of labor law, such as the workplace of an employee, labor function, work mode, work schedule, etc. Today the state lacks a perspective vision of the future employment model of the population, oriented not only to increase the quantitative indicators and to shun labor relations, but above all to ensure qualitative changes in the workplace. It has been discovered that far more people prefer remote independent work to order, taking into account a number of criteria: dis-

\footnotetext{
${ }^{1}$ Postgraduate Student of the Faculty of Law,

Volodymyr Dahl East Ukrainian National University, Ukraine

${ }^{2}$ Ph.D. in Law,

Associate Professor at Department of Law,

Volodymyr Dahl East Ukrainian National University, Ukraine
} 
placement in the demographics of the labor force, the formation of a new type of employee, the development of mobile technologies, a wide network of social connections, innovative education and family status ( worker with family responsibilities). It is proved that the process of digitalization entails modernization of the workplace, the basic principles of which should be: providing employees with mobile communication, using mobile business applications, participating in videoconferences, proper infrastructure and safe digital space. Describes the digital labor market, serving as a new segment in the existing market, whose share and weight is constantly growing. Unfortunately, however, it has to be noted that, despite the large number of people engaged in the digital labor market, in the current labor legislation there is no legal regulation of this form of employment as a distant work, which does not allow freelance persons to be fully to realize the right to work guaranteed by the Constitution of Ukraine.

\section{1. Вступ}

Новизна теми та актуальність наукових рішень. Безперечним є факт, що у сучасних умовах відбувається формування глобального інформаційного середовища. Це є динамічним та об'єктивним процесом, пов'язаним з розвитком інформаційно-комп'ютерних технологій та розповсюдженням їх у всіх напрямах суспільного життя. Наразі констатуємо перехід від індустріальної до інформаційної економіки, що обумовлює процеси трансформації правового регулювання трудового права, зміну змісту трудових правовідносин, характеру та форм зайнятості.

На жаль, сьогодні державі не вистачає перспективного бачення майбутньої моделі зайнятості населення, орієнтованої не тільки і не стільки на збільшення кількісних показників і детінізацію трудових відносин, а більшою мірою спрямованої на забезпечення якісних зрушень у сфері праці, регулювання віртуального трудового простору, розвиток нових, нестандартних форм трудової діяльності.

Правила регулювання бізнесу створюють взаємозв'язок між легкістю ведення бізнесу та новими робочими місцями. Розвиток економіки неможливий без модернізації правил функціонування трудової сфери. Відхилення у бік громіздкого регулювання чи, навпаки, зайве послаблення та гіперболізована лібералізація, призводять до одного підвищення показників тіньової зайнятості та офіційного безробіття, порушення базових соціальних прав. 
Тому розвиток цифрових та інформаційних технологій повинен стимулювати розробку відповідних правил регулювання віртуальних трудових відносин як нетипових форм зайнятості. Це є важливим та актуальним завданням наукових розвідок та дослідницького пошуку.

Мета дослідження та науково-дослідницькі завдання. Зміни, що відбуваються в економічній сфері, формування інформаційного та цифрового простору як нової сфери трудової діяльності, обумовлюють мету дослідження, яке спрямоване на аналіз існуючих та вироблення нових трудоправових підходів до регламентації нетрадиційних, сучасних форм зайнятості та способів реалізації права на працю у сучасному суспільстві. Відповідно до окресленої мети будуть вирішуватися завдання визначення факторів, що впливають на розвиток типології нестандартної зайнятості, з'ясування поняття «цифровізації» та аналіз положень Концепції розвитку цифрової економіки України. Важливим напрямком дослідження також є обгрунтування необхідності суттєвого перегляду усталених в трудовому праві понять, таких як робоче місце працівника, трудова функція, режим роботи, графік роботи тощо.

Методологія дослідження. Досягнення мети і рішення поставлених у дослідженні завдань здійснюється із застосуванням методів логічного і порівняльного аналізу, систематизації та теоретичного узагальнення.

\section{2. Фактори, які впливають на розвиток віддаленої зайнятості}

Зважаючи на стрімкий розвиток цифрових та інформаційних технологій, слід відзначити, що економічний розвиток країни на даному етапі тяжіє до нових форм зайнятості та способів реалізації права на працю у сучасному суспільстві. Розвиток цифрової економіки України полягає «у створенні ринкових стимулів, мотивацій, попиту та формуванні потреб щодо використання цифрових технологій, продуктів та послуг серед українських секторів промисловості, сфер життєдіяльності, бізнесу та суспільства для їх ефективності, конкурентоздатності та національного розвитку, зростання обсягів виробництва високотехнологічної продукції та благополуччя населення» [1]. Отже, нові технології та розвиток цифрової економіки стимулюють розвиток нових форм зайнятості, на які істотно вплинув цілий ряд факторів. До яких, на нашу думку, слід віднести наступні: 
Змімення в демографії робочої сили.

Аналізуючи стан та головні проблеми ринку праці, слід насамперед звернути увагу на демографічні процеси, які відбуваються на ньому. Демографічна криза в Україні, яка характеризується щорічним скороченням чисельності населення від 350 тис. до 400 тис. осіб, вплинула безпосередньо і на чисельність активної робочої сили.

За даними Міжнародної організації праці (МОП) з 2007 р. по 2015 р. чисельність молоді у світі збільшилась на 14,2\%, при цьому зайнятість у цій групі зросла на 4,2\%, досягнувши 357 мільйонів. Рівень безробіття серед молоді виріс із 13,7\% у 2007 р. до 14,9\% у 2015 р. Цей показник значно вищий серед юнаків та дівчат, ніж серед дорослих робітників, де безробіття складає 5,1\%. Частка зайнятих молодих людей у загальній чисельності молоді в останнє десятиріччя скоротилася з 51,6\% до 47,3\% [2].

Така картина свідчить про те, що сучасному суспільству вкрай необхідні зміни, які зможуть знизити рівень безробіття серед молоді та активізувати такий значний сегмент ринку праці. При цьому слід враховувати, що молодь як суб'єкт трудових відносин, прагне і здібна до нестандартних, віддалених форм праці.

Формування працівника нового типу.

Хусаінов Р. В. та Данченко Л. Г. вважають, що «... інноваційна економіка грунтується на знаннях, і це означає, що основним капіталом будьякої економічної структури стає інтелектуальна власність, людський капітал, інноваційні розробки та «ноу-хау», а не матеріальні активи і традиційні ресурси, що ще раз свідчить про трансформацію матеріальної основи капіталу в інтелектуальну» [3, с. 25]. Погоджуючись у цілому з вказаним правовим підходом, слід зазначити, що, дійсно, для підвищення рівня зайнятості та подальшого розвитку економіки знання $€$ неодмінно важливими, але вважаємо за доцільне звернути увагу на те, що підготовка фахівця нового типу повинна здійснюватись через вплив на різні сфери його особистості: когнітивну, особистісну та професійну.

Зокрема слід говорити про такі якості, як: високу мотивацію до творчості, почуття нового, уміння мислити нестандартно, винахідливість, вміння приймати рішення у ситуаціях невизначеності, вміння відстоювати власну позицію, фахову гнучкість і мобільність, вміння вирішувати нетипові завдання, опанувати нову професію, вміння використовувати цифрові технології в роботі тощо. Крім того, кількість 
робочих місць в Україні, що потребують від працівників принаймні базового розуміння інформаційно-комунікаційних та цифрових технологій, стрімко збільшується, а вміння користуватися технологіями стає основною вимогою до персоналу, що є превалюючим чинником, який впливає на формування працівника нового типу.

Вважаємо, що внаслідок підвищення рівня інтелектуалізації праці працівник стає власником найбільш важливого і унікального засобу виробництва - свого людського капіталу. Це стимулює широке використання форм нестандартної зайнятості, оскільки саме вони дають більший рівень свободи, природно при більш високому рівні відповідальності за результати своєї праці.

Розвиток мобільних технологій.

3 огляду на масштаби розвитку та поширення нових технологій, не можна залишити осторонь той факт, що сучасна людина не може прожити повноцінний день без мобільного телефону, а поширення інформації у соціальних мережах набуло значних масштабів.

Нещодавно «стало відомо, що український бот-юрист PatentBot успішно зареєстрував першу торговельну марку в Україні. Відповідна документація, яка свідчить про успішну реєстрацію, вже передана власникам, повідомляє ресурс liga.net”. Назва цієї торгової марки та iiі призначення невідомі, але тут важливіше сам факт успішного завершення процедури. Як повідомляється, на реєстрацію торгової марки за прискореною процедурою пішло 4,5 місяці [4].

Широка мережа соціальних зв'язків.

Слід зауважити, що велика кількість людей намагається створити власний імідж та розширити своє коло зв'язків завдяки використанню соціальних мереж. Це може стосуватися, як взагалі кожної окремої особи, яка або шукає роботу, або вже ії має у тих же самих соціальних мережах, так і певної окремої категорії осіб, які шукають потенційних роботодавців - фрілансери. Як показують дослідження компанії Payoneer, Facebook став однією з найбільш зручних і популярних платформ для професійного просування і спілкування 3 клієнтами. Більше половини фрілансерів (54\%) використовують Facebook для реклами своїх послуг у порівнянні з 38\% в 2015 р Друге місце займає LinkedIn - цю платформу для професійного спілкування використовують 40\% фрілансерів. Під час опитування в 2015 році лише $14 \%$ респондентів вказали LinkedIn в якості майданчика для пошуку роботи. 
Інноваиійна освіта.

Останнім часом багато дослідників наголошують на тому, що сучасний рівень освіти не може повністю якісно забезпечити необхідними знаннями та навичками майбутніх працівників, унаслідок чого з'являються нові форми навчання та тенденції у сфері самоосвіти. Крім того, роботодавців починають цікавити «метапрофесійні та особистісні компетенції - здатність реалізовувати певну позицію, мобільність, відкрите ставлення до світу» [5], які працівники мають розвивати в собі протягом усього часу, що вони працюють.

За останні декілька років значно збільшилася кількість інструментів для розвитку компетентностей, як для працюючого населення, так і для студентів. Зокрема значної популярності набули короткострокові освітні програми за кордоном, які «насамперед надають студентам можливість отримати концептуально нові знання або ж поглибити вже набуті, а також ознайомитися із західною системою освіти, підвищити рівень володіння іноземною мовою» [6].

Крім того, стрімко розвивається онлайн освіта у вигляді масових відкритих онлайн-курсів. «Головною особливістю і водночас перевагою масових відкритих онлайн-курсів є те, що навчатися може кожен, хто бажає (жодних вікових, територіальних, фінансових чи інших обмежень немає), у будь-який час (відеозаписи лекцій, інтерактивні завдання та форуми для обговорення доступні цілодобово) та у будьякому місці...» [7].

Та основною формою розвитку свого професійного рівня, як працівника, так і роботодавця $є$ lifelonglearning, яка визначається як «постійний творчий розвиток і вдосконалення кожної людини протягом усього життя шляхом взаємодії між знаннями, що здобуті на початкових етапах освіти, і знаннями, здобутими на подальших етапах, а також взаємодія між теоретичними та практичними знаннями, що підтверджуються компетентністю в подальшому їх практичному використанні. Вона охоплює базову професійну і подальшу освіту, передбачає послідовне поєднання навчальної і професійної діяльності в освітніх закладах, професійне самовдосконалення на різних життєвих етапах» [8, с. 451].

Сімейний стан (працівник із сімейними обов'язками).

Хоча сімейний стан не має жодного зв'язку з розвитком інформаційно-комунікаційних технологій про які йшлося вище, та не можна 
залишити його осторонь, бо він також є одним з факторів, що впливають на розвиток віддаленої зайнятості. Наразі, у національному законодавстві прямо не закріплена така категорія, як «працівник із сімейними обов'язками».

Слід зазначити, що сьогодні згадка про працівників із сімейними обов'язками є у Конвенції МОП № 156 «Про рівне ставлення і рівні можливості для трудящих чоловіків і жінок: трудящі із сімейними обов'язками», яка ратифікована Законом України від 22 жовтня 1999 р. і $є$ частиною національного трудового законодавства. Положення даної конвенції набули детального розвитку у Рекомендації № 165 «Про рівне ставлення і рівні можливості для трудящих чоловіків і жінок: трудящі iз сімейними обов'язками», яка зазначає, що працівники «із сімейними обов'язками, які виконують або бажають виконувати оплачувану роботу, здійснювати своє право на це, не підлягаючи дискримінації та, по змозі, гармонійно поєднуючи сімейні й професійні обов'язки» [9].

Зокрема працівниками із сімейними обов'язками, відповідно до ст. 287 проекту ТК України, визнаються мати, батько, усиновлювач, опікун, піклувальник, прийомні батьки, а в окремих випадках, передбачених цим Кодексом, - інший член сім’ї [10]. Вважаємо, що уніфікований підхід до регулювання праці чоловіків та жінок із сімейними обов'язками може забезпечити останнім рівні можливості у зайнятості та конкурентоспроможність на ринку праці. Вірогідно, і національне законодавство має враховувати зазначені тенденції.

Отже, виникнення віддаленої зайнятості, яка значно набирає оберти на сьогоднішньому ринку праці, є закономірним процесом трансформації сфери зайнятості, як в Україні, так і по всьому світу. Було доведено, що стрімкий розвиток віддаленої зайнятості обумовлюється рядом факторів, до яких належать: зміщення в демографії робочої сили, формування працівника нового типу, розвиток мобільних технологій, широка мережа соціальних зв'язків, інноваційна освіта ті сімейний стан (працівник із сімейними обов'язками).

\section{3. Цифровізація робочого місця}

У XXI столітті важливу роль у житті кожного відіграє інформаційний простір у якому він знаходиться. Слід звернути увагу на те, що застосування комп'ютерної техніки, інформаційних технологій та мережі Internet, об'єднує людей з різних країн в єдине світове співто- 
вариство, яке не має жодних обмежень. Роль мережі Internet в такому співтоваристві зростає надзвичайно швидко, а розміщена інформація $\epsilon$ не тільки найважливішим фактором спілкування, володіння новими знаннями, освіти і виховання, але також необхідним засобом супроводження товарів і послуг, укладення угод, працевлаштування, підтвердження подій, фактів тощо.

Стрімко зростає кількість і значення даних, створених або записаних в цифровому форматі. Збільшується і потреба компаній в професіоналах, здатних управляти великими масивами цифровими даними, забезпечувати їх конфіденційність і кіберзахист. Крім того, завдяки стрімко зростаючій цифровізації, з'явилася можливість виконання своїх безпосередніх трудових обов'язків віддалено від робочого місця.

17 січня 2018 року була схвалена Концепція розвитку цифрової економіки, яка зазначає, що цифровізація це «насичення фізичного світу електронно-цифровими пристроями, засобами, системами та налагодження електронно-комунікаційного обміну між ними, що фактично уможливлює інтегральну взаємодію віртуального та фізичного, тобто створює кіберфізичний простір» [11].

В епоху цифровізації економіки новим трудовим активом стають інформаційні дані та працівники, які в змозі ефективно їх використовувати. Цей процес потребує не тільки оптимізації інфраструктури, а й реформування ринку праці. Сьогодні велику кількість процесів у діяльності більшості установ автоматизовано, а програмне забезпечення є спеціалізованим, сучасним і таким, яке постійно оновлюється. Проте все частіше стратегічні рішення потребують аналітичної підтримки. Тому набувають важливості стратегічна роль і впровадження інноваційних підходів у зайнятості населення.

Основними цілями цифрового розвитку є:

- прискорення економічного зростання та залучення інвестицій;

- трансформація секторів економіки в конкурентоспроможні та ефективні;

- технологічна та цифрова модернізація промисловості та створення високотехнологічних виробництв;

- доступність для громадян переваг та можливостей цифрового світу;

- реалізація людського ресурсу, розвиток цифрових індустрій та цифрового підприємництва. 
Цифровізація здійснюється через механізм економічного зростання шляхом підвищення ефективності, продуктивності та конкурентоздатності від використання цифрових технологій. Цей принцип передбачає досягнення цифрової трансформації галузей економіки, сфер діяльності, набуття ними нових конкурентних якостей та властивостей. Всеохоплююча цифровізація має на меті комплексне та глибоке перетворення існуючих аналогових економічних, соціальних систем та сфер у нову цінність та якість для їх ефективності, розвитку, зручності використання тощо. Цифровізація створює нові можливості для інвестиційної діяльності та нові робочі місця [11]. Тобто, процес цифровізації, який було активовано Концепцією розвитку цифрової економіки та суспільства України на 2018 - 2020, став об'єктивною причиною для трансформації інституту зайнятості населення та переходу від стандартних до нових нестандартних форм зайнятості та створення нового виду робочих місць.

Трансформації, пов'язані із переходом на цифрові технології, створюють нові підходи та стилі діяльності, котрі в свою чергу ведуть до суттєвого перегляду усталеного в суспільстві поняття «робоче місце». У «цифровому» світі робочі місця перестають бути прив'язаними до фізичних місць - вони стають «цифровими», мобільними, тобто такими, що загалом не потребують постійного перебування працівника на робочому місці. Саме віртуально-цифровий світ надає потужні можливості задля постійного перебування працівника в онлайн-режимі. Цей тренд поширюється надзвичайно швидко й позитивно сприймається переважною більшістю працівників, яким подобаються гнучкі способи роботи, котрі дозволяють приділяти більше уваги клієнтам, друзям, сім'ї. Це може не тільки сприяти збереженню кваліфікованих працівників, але й збільшити податкові надходження, внески соціального страхування, а головне - впливати на ринок зайнятості [12].

Концепція «цифрових робочих місць» поширюється надзвичайно швидко у бізнес-середовищі та позитивно сприймається переважною більшістю працівників, яким подобаються гнучкі способи роботи, можливість працювати вдома, на відпочинку, тобто з будь-якого місця [11].

Відповідно до концепції «цифрове робоче місце - віртуальний еквівалент фізичного робочого місця, котрий вимагає належної організації, користування та управління, оскільки воно має стати запорукою підвищеної ефективності працівників та створення для них більш сприятли- 
вих умов праці» [11]. 3 даного визначення розуміємо, що організація має забезпечити належне функціонування типових елементів таких як, електронна пошта, інтернет та веб-конференції. Проте, основний управлінський акцент робиться на співробітника, що дозволяє визначити цифрове робоче місце не просто збірним терміном для всіх зазначених технологій.

Видимі частини цифрового робочого місця - це технології і методи роботи, які дозволяють людям об'єднуватися, спілкуватися і взаємодіяти, не обов'язково перебуваючи лицем до лиця. Одна зі статей Deloitte показує це в такий спосіб: «Цифрове робоче місце включає в себе всі технології, які люди використовують 3 метою виконання роботи на сучасному робочому місці. Ці технології варіюються від HR-додатків і бізнес-додатків до електронної пошти, миттєвих повідомлень, а також корпоративних соціальних комунікації і віртуальних зустрічей» [13].

Цифрове робоче місце сприяє гнучкості в методах виконання безпосередніх трудових обов'язків, стимулює спільну роботу та взаємодію, підтримує мобільне та інтерактивне робоче середовище, передбачає вибір технологій для роботи. Перевагами цифрових робочих місць $\epsilon$ зменшення витрат на апаратне забезпечення, офісні приміщення, відрядження тощо - зазначено у Концепції.

Ефективне цифрове робоче місце відокремлює роботу від фізичного місця розташування протягом більшої частини часу. Подібне «звільнення» людини має ряд важливих наслідків не тільки для того, де працюють люди, а й для того, як формуються команди і як люди збираються разом, щоб вирішити локальні проблеми. Віце-президент Microsoft в Західній Європі Klaus Holsec формулював це так: «У майбутньому успішними будуть ті компанії, які зламають бар'єри між людьми, їх робочим місцем і технологіями, а також дадуть можливість співробітникам бути продуктивними і креативними, де б вони не знаходилися. < ..> Це вимагає такої корпоративної культури, яка ставить на перше місце саме людей» [13].

В Україні планується перетворення робочих місць державних службовців у цифрові робочі місця. Це передбачено Концепцією розвитку цифрової економіки та суспільства України на 2018-2020 роки. Наразі вже зроблено перші кроки на шляху до такого перетворення.

Отже, можемо з упевненістю говорити про те, що процес цифровізації тягне за собою важливі структурні зміни у сфері зайнятості 
населення. Розвиваються нові форми зайнятості, що тягне за собою трансформацію такої важливої умови прі, як робоче місце, основними принципами створення якого мають бути: забезпечення співробітників мобільним зв'язком, використання мобільних бізнес-додатків, участь у відеоконференціях, правильна інфраструктура та безпечний цифровий простір.

\section{4. Віртуальний ринок праці та фріланс}

Формування глобального інформаційного середовища є об'єктивним процесом, в основі якого лежить активний розвиток інформаційно-комп'ютерних технологій та повсюдне проникнення їх у всі сфери суспільства. Перехід від індустріальної до інформаційної економіки та прискорений розвиток інформатизації суспільства обумовлюють процеси трансформації ринку праці, зміни змісту і характеру праці.

На нашу думку, особливості змісту праці в інформаційній економіці полягають в наступному:

• по-перше, підвищується рівень інтелектуалізації праці;

- по-друге, зменшується частка важкої, монотонної праці, стереотипних операцій;

- по-третє, результат праці все більше залежить від творчості, уміння приймати нестандартні рішення, орієнтуватися у значних інформаційних потоках, можливості продукувати інновації;

- по-четверте, творчість дає значні можливості для самореалізації. Продукт творчості у речовій формі близький до матеріального продукту, проте він є унікальним та не підлягає відтворенню або налагодженню масового виробництва.

Слід зазначити, що незважаючи на актуальність цифровізації суспільного життя та інноваційність економіки, яка тягне за собою реформацію ринку праці єдиного визначення віртуального ринку в цілому, та віртуального ринку праці зокрема, в наш час, поки що немає. Так, Романов А.Н., Одинцов Б.Е. розуміють під віртуальним ринком «віртуальний простір, де економічні суб'єкти за допомогою продажу і придбання комунікаційних та інформаційних послуг здійснюють комерційні операції». Бугорський В.Н. «безліч продавців і покупців певного електронного товару (продукту або послуги)». Румянцев В.Ф., Баркалов С.А., Гурєєва І.В., Кравців В.А. розуміють під віртуальним ринком «пропоновані системою Інтернет комунікаційні та інформаційні 
послуги комерційного призначення» [14]. Відповідно до нашої точки зору, видається неправомірним обмежувати віртуальний ринок придбанням тільки комунікаційних та інформаційних послуг. По суті, на віртуальному ринку можуть продаватися і купуватися товари і послуги, що мають речову форму.

Водночас Е. В. Бутурлакіна переконана, що інформаційнокомп'ютерні технології не є сутністю віртуального ринку, а об'єктивно технологічним середовищем, яке обумовлює його існування. Дослідниця вважає, що віртуальний ринок - це система економічних відносин між географічно розподіленими суб'єктами, які функціонують завдяки комунікаційним та інформаційним можливостям глобальної мережі (інтернет), з приводу купівлі-продажу товарів та послуг, де з урахуванням ринкових сигналів цілодобово, в режимі реального часу визначається їх кінцева вартість. За економічним призначенням віртуальний ринок вченими поділяється на віртуальний ринок товарів та послуг; віртуальний ринок інформації; віртуальний ринок праці [15, с. 69, 71].

Інформаційно-комп'ютерні технології змінюють не тільки процес праці, а й форму iii організації. Інформатизація трудового процесу створює передумови для існування і розвитку віртуального ринку праці. Віртуальний ринок праці характеризується наступними ознаками: по-перше, наявністю інформаційної праці, результатом якої $\epsilon$ інформаційний товар (послуга); по-друге, наявністю віртуальної інфраструктури, до складу якої входять онлайн платформи для пошуку роботи і пропонування послуг, електронні платіжні системи, інформаційні системи тощо; по-третє, наявністю віртуальних суб'єктів, таких як: замовники послуг та працівники (електронні фрілансери) [16, с. 219].

Зародження віртуального ринку праці пов'язане з інформаційними технологіями, з їхнім стрімко зростаючим потенціалом та постійним здешевленням, які відкривають значні можливості для появи нових шляхів для пошуку та пропозиції праці, а також для іiі організації, як у межах окремих компаній, так і суспільства в цілому. Б. Балансинович визначає віртуальний (електронний) ринок праці, як кібернетичне середовище, в якому відбуваються відносини з приводу обміну інформацією про вільні вакансії та наявну робочу силу і в якому (за допомогою інформаційних та комунікаційних технологій) стикаються попит i пропозиція на працю та на робочу силу [17, с. 30]. 
Ю. Ф. Камалова трактує поняття «електронного ринку праці» як нову форму узгодження інтересів роботодавців та працівників, яка характеризується специфічним змістом та характером трудової діяльності, $є$ заснованим на сучасних інформаційних технологіях [18, c. 18-19].

В. В. Рєзникова дає визначення електронному ринку праці як своєрідному сегменту ринку праці, що характеризується специфічним механізмом взаємодії основних суб'єктів цього ринку. Дослідниця наголошує на розповсюдженні та всебільшій значимості мережевих технологій на електронному ринку праці, що продукуються інформаційним сектором, зокрема Інтернет. Під впливом інформаційних технологій в цілому, й Інтернету зокрема, істотно перетворюється сфера зайнятості й соціально-трудові, господарсько-трудові відносини [19]. Н. Азьмук визначає цифровий ринок праці вчений як специфічний сегмент глобального ринку праці, на якому дистанційно формуються попит та пропозиція на трудові цифрові послуги, при цьому взаємодія його суб'єктів здійснюється виключно 3 використанням інформаційно-комп'ютерних технологій [20, с. 39].

Вищесказане дозволяє сформулювати власне визначення цифрового ринку праці - це специфічний сегмент глобального ринку праці зі специфічним предметом та сферою діяльності на якому віддалено формуються попит і пропозиція на різноманітні трудові послуги, при цьому взаємодія його суб'єктів відбувається виключно за допомогою сучасних інформаційно-комп'ютерних технологій.

Головна стратегія віртуальної інфраструктури віртуального ринку праці пов'язана з орієнтацією на забезпечення активної підтримки інноваційних процесів, які відбуваються в різних галузях національної економіки 3 метою практичної реалізації інноваційних інформаційних продуктів та задоволення всезростаючих потреб суспільства. Глобальна стратегічна мета функціонування віртуальної інфраструктури віртуального ринку праці - забезпечення конкурентоспроможності національного ринку праці у довгостроковому періоді, сприяння розвитку інноваційного та інтелектуального потенціалу суспільства.

Важливою складовою віртуального ринку праці вважається його, своєрідна за своєю природою, віртуальна інфраструктура, яка динамічно замінює традиційну інфраструктуру та використовує он-лайнові технології. До складу віртуальної інфраструктури ринку праці вчені 
[16, с. 220] включають: онлайн платформи для пошуку роботи і пропонування послуг; електронні платіжні системи; інформаційні системи тощо.

О. Сєнокосова виділяє в мережевій інфраструктурі віртуального ринку праці окремі інститути в вигляді бірж праці для IT-фахівців, соціальних мереж і груп, для різних професій, для міст, в вигляді віртуальної інфраструктури віртуального ринку праці. О. Сєнокосова включає мережеві формальні та неформальні інститути ринку праці. Мережеві формальні інститути ринку праці - це електронний уряд, електронна податкова інспекція, електронна поліція, безпечна інформаційна інфраструктура, правове регулювання діяльності в мережі Інтернет [21, с. 144].

Вважаємо, що «віртуальна інфраструктура» віртуального ринку праці - це мережева система інститутів ринку праці; яка завдяки використанню інформаційно-комп'ютерних технологій та мережі інтернет, формує нові, гнучкі умови для дистанційної, цифрової зайнятості та цілодобової праці, забезпечуючи однаковий доступ до інформації та даючи можливість знижувати затрати на пошук, як потенційного працівника, так і відповідного місця роботи, розвиває i «нового працівника», і «нового роботодавця», які набувають нових компетенцій у сфері праці.

Отже, сьогодні віртуальний ринок праці показує стабільний приріст з моменту появи перших хед-хантінгових ресурсів. Зараз це вже не лише сайти 3 пошуку роботи, а й фріланс-біржі, краудфандингові платформи, професійні соціальні мережі, групи і сторінки в соціальних мережах, кар'єрні сайти чи розділи компаній і організацій. Сайти рекрутингових компаній і кар'єрних консультантів, служб зайнятості та профільних асоціацій також $є$ активними учасниками трудового віртуального простору - нарівні з профільними онлайн-сервісами та мобільними додатками [22].

До найпопулярніших інтернет-бірж праці світового рівня можна віднести "Elance", "Freelance Switch Jobs", “oDesk". За даними офіційного сайту www.elance.com, однієї 3 найбільших онлайнових фріланс-бірж, станом на 2016 рік на ній були зареєстровані понад 10 мільйонів фрілансерів [23]. Розвивається також ринок українських фріланс-бірж, де фрілансери можуть реєструватися та працювати безкоштовно, а за бажання оформити «угоду без ризику», яка дає змогу 
отримати гарантію оплати, а також гарантію повернення коштів у разі невиконання угоди фрілансером.

Серед найпопулярніших інтернет-бірж в Україні слід назвати такі: https://freelancehunt.com, https://freelance.ua, https://www.weblancer.net, https://free-lance.ua, https://kabanchik.ua/freelance, https:/globalfreelance. ua. Відповідні інтернет-платформи забезпечують офіційні договори, які дають змогу вести діяльність з фрілансу офіційно.

На вказаних онлайнових платформах формується пропозиція робочої сили і попит на неї фіксується, тут також формуються умови найму, оплати і оцінка результатів праці. Цифрова зайнятість реалізується в двох основних формах: електронний фріланс і електронний аутсорсинг.

Електронний фріланс є перспективною гнучкою формою зайнятості, яка дає можливість дистанціювати працівника від роботодавця. Концепцію віддаленої роботи (remotework) обгрунтував Дж. Ніллес ще на початку 1970-х років, коли він керував першим подібним проектом в університеті Південної Каліфорнії, проте іiї повноцінна масова реалізація стала можлива пізніше завдяки подальшому розвитку технологій зв'язку, здатних оперативно передавати великі обсяги інформації [24].

Сам же термін e-lancer - «електронний фрілансер»вперше з'явився в 1998 р в статті Томаса Малоун іРоберта Лойбахера і був утворений за аналогією з неологізмамі e-mail - електронна пошта, e-business електронний бізнес. Можна також зустріти похожий термін web-lancer «мережевий фрілансер» [25].

Електронний фрілансер - це фрілансер, який здійснює свою трудовою діяльність віддалено з використанням інформаційно-комунікаційних технологій. Необхідний сучасний набір електронного фрілансера, для спілкування з клієнтами і отримання завдань, складається 3 наявності: Інтернету, комп'ютера, електронної пошти, ICQ, Skype, мобільного телефону, пластикової карти або електронного гаманця Webmoney.

Згідно даних спільного звіту двох найбільших онлайн-платформ "Elance" i “Odesk” на кінець 2014 року кількість зареєстрованих на них фрілансерів становило - 9,7 млн осіб, а роботодавців - 3,8 млн. Тільки на цих двох платформах сукупний заробіток фрілансерів за період 3 2009 по 2014 р зріс з трохи менше 500 млн дол США до 3,2 млрд дол. США. При цьому середній заробіток за час роботи варіюється від 
13 до 27 дол. США в залежності від складності виконання робіт і статусу розробника [26].

За оцінками експертів біржі Elance, до 2020 р фрілансери складуть $60 \%$ всього світового ринку праці, а оборот ринку віддаленої роботи досягне 46 млрд. дол. США [27].

Електронний фріланс охоплює досить широкий спектр видів економічної діяльності: програмування, створення контенту і переклад, маркетингові дослідження, продаж, консалтинг, фінансовий облік, адміністрування. Згідно з даними спільного звіту "Elance" i “Odesk" найбільшу питому вагу в структурі послуг мають: розробка технологій (50\%), адміністративна підтримка (12\%), створення контенту і переклад (12\%), дизайн і мультимедійні розробки (9\%), розробка мобільних додатків (8\%). Замовниками послуг у фрілансерів є такі компанії, як: "Microsoft", "Disney", “Amazon", "Cisco", "OpenTable", "Pinterest" і багато інших [27].

Загальновідомим фактом $є$ те, що українські програмісти та фахівці в галузі інформаційного забезпечення є одними з найкращих. У той же час, за статистикою, переважна більшість 3 них працює на іноземні компанії, часто не оформлюючи належним чином такі трудові відносини.

Так було проведено дослідження ринку аутсорс-програмування Східної Європи, компанію є “Тор \$ dev" - сервіс пошуку програмістів та IT-рекрутингу. У цьому дослідженні проаналізовані дані більше 88 тис. профілів фрілансерів і 260 тис. проектів на загальну суму більш ніж 350 млн дол. США, надані найбільшими фріланс-біржами. За його результатами Україна в 2014 р. є лідером серед країн Східної Свропи у сумі замовлень на ІТ-послуги. Частка України на цьому ринку складає $33 \%$, другу і третю позицію займають Росія (21,8\%) і Румунія (9\%) [28].

Найбільшими центрами IT-фріланса в 2014 р. в Східній Європі за обсягами виконаних замовлень, стали такі українські міста: Харків (6,74\%), Київ(6,63\%), Львів (3,33\%) та Запоріжжі $(3,07 \%)$. п'яту і шосту позицію в рейтингу займають російські міста: Омськ $(3,06 \%)$ і Москва (2,88\%) [29]. представлені дані свідчать про те, що Україна $€$ одним з найбільших експортерів талантів в сфері інформаційних послуг для розвинених країн.

Фріланс, як явище, отримав надзвичайно широку поширеність 3 розвитком Інтернету. Варто зазначити, що на міжнародному рівні вже 
досить давно діють такі нормативні акти, як Конвенція Міжнародної організації праці «Про надомну працю» № 177 від 20.06.1996 та Конвенція Міжнародної організації праці про гідну працю домашніх працівників (фрілансерів) № 189 від 16.06.2011, які покликані врегульовувати такого роду правовідносини. Вітчизняне ж законодавство до таких нововведень не поспішає, адже жодна 3 цих конвенції не була ратифікована Україною, хоча завдяки правильному нормативно-правовому регулюванню інформаційної сфери з'являється потенційна можливість залучення багатомільйонних інвестицій в економіку України.

Головною проблемою $є$ те, що багато фрілансерів ніколи не укладають трудового договору. Крім того, в даний час чимало незалежних фахівців, які оформили свою діяльність як індивідуальні підприємці. Це дає їм можливість будувати відносини з замовниками на основі цивільно-правових договорів. При цьому робота таких індивідуальних підприємців має ознаки фрілансу, тобто вони працюють віддалено, поза місцем розташування замовника із застосуванням сучасних інформаційних технологій. В основному індивідуальні підприємці виконують роботу особисто, але деякі з них додатково можуть наймати співробітників для виконання окремих функцій, які в разі задоволення критеріям з нашого визначення, також будуть фрілансерами.

\section{5. Висновки}

Підводячи підсумок даного наукового дослідження зазначимо, що сьогодні державі не вистачає перспективного бачення майбутньої моделі зайнятості населення, орієнтованої не тільки на збільшення кількісних показників і детінізацію трудових відносин, а й перш за все на забезпечення якісних зрушень у сфері праці.

Наразі віддалена зайнятість поширюється дуже швидко, усе більше людей надають перевагу віддаленій самостійній роботі на замовлення 3 огляду на низку критеріїв: зміщення в демографії робочої сили, формування працівника нового типу, розвиток мобільних технологій, широка мережа соціальних зв'язків, інноваційна освіта ті сімейний стан (працівник із сімейними обов'язками).

Процес цифровізації тягне за собою модернізацію робочого місця, основними принципами створення якого мають бути: забезпечення співробітників мобільним зв'язком, використання мобільних біз- 
нес-додатків, участь у відеоконференціях, правильна інфраструктура та безпечний цифровий простір.

В умовах інформаційного суспільства цифровий ринок праці виступає новим сегментом у складі наявного ринку, частка і вагомість якого постійно зростає. Однак, на жаль доводиться констатувати, що, не зважаючи на велику кількість осіб, які зайняті на цифровому ринку праці, у діючому трудовому законодавстві відсутня нормативно-правова регламентація такої форми зайнятості як віддалена праця, що не дозволяє особам, які займаються фрілансом, у повному обсязі реалізувати право на працю, яке гарантовано Конституцією України.

У рамках правового регулювання повинна відбутися легалізація цифрових трудових відносин, повинен бути вирівняний статус усіх учасників соціально-трудових відносин: і тих, які працюють на умовах постійної/тимчасової зайнятості, і тих, які задіяні на засадах віддалених форм зайнятості (фріланс, аутсорсинг тощо). За допомогою правових засобів повинні бути забезпечені гідні умови роботи для суб'єктів цифрового ринку праці на рівні з іншими працівниками, задіяними в операційній діяльності підприємств.

Виходячи з вищенаведеного пропонуємо врегламентувати у проекті Трудового кодексу України віддалену форму зайнятості та закріпити визначення поняття цифровий ринок праці як «специфічний сегмент глобального ринку праці зі специфічним предметом та сферою діяльності, на якому віддалено формуються попит і пропозиція на різноманітні трудові послуги, при цьому взаємодія його суб'єктів відбувається виключно за допомогою сучасних інформаційно-комп'ютерних технологій».

\section{Список літератури:}

1. Концепція розвитку цифрової економіки та суспільства України на 2018-2020 роки Схвалено розпорядженням Кабінету Міністрів України від 17 січня 2018 p. № 67-p [Електронний ресурс]. - Режим доступу: https://www. kmu.gov.ua/ua/npas/pro-shvalennya-koncepciyi-rozvitku-cifrovoyi-ekonomiki-tasuspilstva-ukrayini-na-20182020-roki-ta-zatverdzhennya-planu-zahodiv-shodoyiyi-realizaciyi

2. Report "Global Employment Trends for Youth 2016" [Електронний pecypc]. - Режим доступу: http://www.ilo.org/trends.

3. Хусаінов Р. В., Данченко Л. Г. Інституційні умови та механізми активізації інноваційної діяльності в Україні / Р. В. Хусаінов, Л. Г. Данченко // Стан та проблеми розвитку національної економіки в умовах перманентних кри- 
зових явищ / за ред. д.е.н., професора О. О. Непочатенко. - Умань: Видавець «Сочінський», 2015. - 236 с.

4. Боты-юристы в Украине: первая зарегистрированная торговая марка и развод онлайн [Електронний ресурс]. - Режим доступу: https://itc.ua/news/ botyi-yuristyi-v-ukraine-pervaya-zaregistrirovannaya-torgovaya-marka-i-razvodonlayn/

5. Нові тренди бізнес-освіти [Електронний ресурс]. - Режим доступу: http://kibit.edu.ua/news/novye-trendy-biznes-obrazovaniya/

6. Короткострокові академічні програми [Електронний ресурс]. - Режим доступу: http://yourinsa.com/ua/programi/korotki-akademichni-programi.

7. Тепла М. Масові відкриті онлайн-курси в Україні: сучасні тенденції розвитку, можливості та досягнення [Електронний ресурс] / Мирослава Тепла. 2016. - Режим доступу: http://ir.kneu.edu.ua/bitstream/2010/20402/1/82-84.pdf.

8. Задорожна Н. Т. Енциклопедія освіти / Н. Т. Задорожна, Т. В. Кузнецова. Медіа-освіта. - Акад. пед. наук України / Гол.ред. В. Г. Кремень К.: Юрінком Інтер, 2008. - 1040 с.

9. Рекомендація щодо рівних можливостей та рівного ставлення до працівників чоловіків і жінок: працівники із сімейними обов'язками [Електронний pecypc] - Режим доступу: http://zakon2.rada.gov.ua/laws/show/993_275.

10. Проект Трудового кодексу України [Електронний ресурс] - Режим доступу: http://w1.c1.rada.gov.ua/pls/zweb2/webproc4_1?pf3511=53221.

11. Розпорядження КМУ від 17 січня 2018 р. № 67-p «Про схвалення Концепції розвитку цифрової економіки та суспільства України на 2018 2020 роки та затвердження плану заходів щодо іiі реалізації». [Електронний peсурс] - Режим доступу: https://www.kmu.gov.ua/ua/npas/pro-shvalennyakoncepciyi-rozvitku-cifrovoyi-ekonomiki-ta-suspilstva-ukrayini-na-20182020roki-ta-zatverdzhennya-planu-zahodiv-shodo-yiyi-realizaciyi.

12. Проект Цифрова адженда України - 2020 («Цифровий порядок денний» - 2020) Концептуальні засади (версія 1.0) [Електронний ресурс]. 2016. - Режим доступу: https://ucci.org.ua/uploads/files/58e78ee3c3922.pdf.

13. What a Digital Workplace Isand What It Isn't [Електронний ресурс] - Режим доступу: https://www.cmswire.com/cms/social-business/what-a-digital-workplaceis-and-what-it-isnt-027421.php.

14. Проблемы экономики и менеджмента: информ.-аналит. журн. [текст] / учредитель ИП Самохвалов А.В. - 2011. - октябрь.

15. Бутурлакіна Е. В. Виртуальный рынок как новый тип рынка в информационной экономике / Е. В. Бутурлакіна // Современная экономика: проблемы и решения. - 2012. - № 5 (29). - С. 65-75.

16. Азьмук Н. А. Трансформація процесу праці в інформаційній економіці / Н. А. Азьмук // Соціально-трудові відносини: теорія та практика. - 2014. № 2 (8). - С. 217-223.

17. Баласинович Б. Вплив інформаційно-комунікаційних технологій на ринок праці і зайнятість населення / Б. Баласинович // Україна: аспекти праці. - 2005. - № 1. - С. 30-34.

18. Камалова Ю. Ф. Особенности трудового посредничества на основе современных информационных технологий : автореф. дис. на соискание 
учен. Степени канд. экон. наук : 08.00.05 «Экономика и управление народным хозяйством (экономика труда)» / Ю. Ф. Камалова. - М., 2004. - 26 с.

19. Рєзнікова В. В. Правове регулювання посередництва на ринку праці / В. В. Рєзнікова // Університетські наукові записки, 2010. - № 4 (36). - С. 104-115.

20. Азьмук Н. А. Сутність, особливості та функції цифрового ринку праці / Н. А. Азьмук // Економіка, 2015. - № 5 (170). - С. 38-43.

21. Сенокосова О. В. Сетевые институты рынка труда / О. В. Сенокосова // Изв. Сарат. ун-та. Сер. Экономика. Управление. Право. - 2014. - Т. 14, вып. 1, ч. 2. - С. 142-146.

22. Пошуки вакансії в Мережі: особливості віртуального ринку праці [Електронний ресурс] - Режим доступу: http://forbes.net.ua/ua/opinions/1424726poshuki-vakansiyi-v-merezhi-osoblivosti-virtualnogo-rinku-praci.

23. Офіційний сайт інтернет-біржі “Еlance” [Електронний ресурс]. Режим доступу: http://www.elance.com

24. Nilles J. Managing Telework: Strategies for Managing the Virtual Workforce/J. Nilles.-N.-Y.: Wiley, 1998 [Електронний ресурс].-Режим доступу: http://trove.nla.gov.au/work/7769072?q\&versionId=8952146.

25. T. W. Malone, R. J. Laubacher. The dawnofthe e-lance economy. Harvard Business Review. September-October 1998, Reprint 98508.

26. Online Work Report. United States, 2014 Full Year Data. - [Electronic resource] // Elance-odesk: [website]. - [online] Availableat: http://elance-odesk. com/online-work-report-us

27. Global Freelancer Survey. - [Electronicresource] // Elance: [website] [online] Availableat: https://www.elance.com.

28. Дослідження сервісом top $\$$ dev ринку аутсорс-програмування Східної Європи [Електронний ресурс]. - Режим доступу http://topsdev.org/blog/obzorrinka-freelance-2014.htm.

29. Дослідження: університети та міста на ринку аутсорс-програмування Східної Європи [Електронний ресурс]. - Режим доступу http://topsdev.org/ blog/obzor-universitiesfreelance-2014.htm.

\section{References:}

1. (2018) Koncepcija rozvytku cyfrovoji ekonomiky ta suspiljstva Ukrajiny na 2018-2020 roky Skhvaleno rozporjadzhennjam Kabinetu Ministriv Ukrajiny vid 17 sichnja 2018 r. \# 67-r [Concept of development of digital economy and society of Ukraine for 2018-2020 Approved by the order of the Cabinet of Ministers of Ukraine dated January 17, 2018 No. 67-p]. Available at: https://www.kmu.gov.ua/ ua/npas/pro-shvalennya-koncepciyi-rozvitku-cifrovoyi-ekonomiki-ta-suspilstvaukrayini-na-20182020-roki-ta-zatverdzhennya-planu-zahodiv-shodo-yiyi-realizaciyi (accessed 01 March 2018).

2. Report "Global Employment Trends for Youth 2016" Available at: http://www.ilo.org/trends. (accessed 03 March 2018).

3. Khusainov R. V., Danchenko L. Gh.(2015) Instytucijni umovy ta mekhanizmy aktyvizaciji innovacijnoji dijaljnosti v Ukrajini [Institutional Conditions and Mechanisms for Activating Innovation in Ukraine]/ Stan ta problemy rozvytku nacionaljnoji ekonomiky $v$ umovakh permanentnykh kryzovykh javyshh [Status and 


\section{Hnidenko Viktoriia, Kaplina Halyna}

Problems of the Development of the National Economy in Conditions of Permanent Crisis] Umanj, Sochinsjkyj, pp. 25-28.

4. Boty-jurysty v Ukrayne: pervaja zareghystryrovannaja torghovaja marka y razvod onlajn [Lawyers in Ukraine: the first registered trademark and online distribution]. Available at: https://itc.ua/news/botyi-yuristyi-v-ukraine-pervayazaregistrirovannaya-torgovaya-marka-i-razvod-onlayn/(accessed 27 February 2018).

5. Novi trendy biznes-osvity [New trends in business education]. Available at: http://kibit.edu.ua/news/novye-trendy-biznes-obrazovaniya/(accessed 25 February 2018).

6. Korotkostrokovi akademichni proghramy [Short-term academic programs]. Available at: http://yourinsa.com/ua/programi/korotki-akademichni-programi. (accessed 27 February 2018).

7. Tepla M. (2016) Masovi vidkryti onlajn-kursyv Ukrajini: suchasni tendenciji rozvytku, mozhlyvosti ta dosjaghnennja [Massive open online courses in Ukraine: current trends, opportunities and achievements] Available at: http://ir.kneu.edu.ua/ bitstream/2010/20402/1/82-84.pdf. (accessed 27 February 2018).

8. Zadorozhna N. T. (2008) Encyklopedija osvity [Encyclopedia of Education]. Kiev: Jurinkom Inter. (in Ukrainian)

9. Rekomendacija shhodo rivnykh mozhlyvostej ta rivnogho stavlennja do pracivnykiv cholovikiv $i$ zhinok: pracivnyky iz simejnymy obov'jazkamy [Recommendation on Equal Opportunities and Equal Treatment for Men and Women Workers: Workers with Family Responsibilities] Available at: http://zakon2.rada.gov.ua/laws/show/993 275. (accessed 28 February 2018).

10. Proekt Trudovogho kodeksu Ukrajiny [Draft Labor Code of Ukraine]. Available at: http://w1.c1.rada.gov.ua/pls/zweb2/webproc4_1?pf3511=53221. (accessed 03 March 2018).

11. Rozporjadzhennja KMU vid 17 sichnja 2018 r. \# 67-r "Pro skhvalennja Koncepciji rozvytku cyfrovoji ekonomiky ta suspiljstva Ukrajiny na 2018-2020 roky ta zatverdzhennja planu zakhodiv shhodo jiji realizaciji”. [Decree of the Cabinet of Ministers of Ukraine dated January 17, 2018, No. 67-p "On Approval of the Concept for the Development of the Digital Economy and Society of Ukraine for 2018-2020 and approval of the plan of measures for its implementation".]. Available at: https://www.kmu.gov.ua/ua/npas/pro-shvalennya-koncepciyi-rozvitku-cifrovoyiekonomiki-ta-suspilstva-ukrayini-na-20182020-roki-ta-zatverdzhennya-planuzahodiv-shodo-yiyi-realizaciyi. (accessed 01 March 2018).

12. (2016) Proekt Cyfrova adzhenda Ukrajiny - 2020 ("Cyfrovyj porjadok dennyj" - 2020) Konceptualjni zasady (versija 1.0) [Digital Aidge Project of Ukraine 2020 (Digital Agenda - 2020) Conceptual framework (version 1.0)]. Available at: https:/ucci.org.ua/uploads/files/58e78ee3c3922.pdf. (accessed 01 March 2018).

13. What a Digital Workplace Isand What It Isn't. Available at: https://www.cmswire.com/cms/social-business/what-a-digital-workplace-is-andwhat-it-isnt-027421.php. (accessed 04 March 2018).

14. Samokhvalov A.V. (2011) Problemy ekonomyky y menedzhmenta: ynform.analyt. zhurn. [Problems of Economics and Management: inform. Analyst. (in Russian) 


\section{Analysis of trends for development of distantly employment in Ukraine}

15. Buturlakina E. V. (2012) Virtualnyiy ryinok kak novyiy tip ryinka V informatsionnoy ekonomike [Virtual market as a new type of market in the information economy]. Modern Economics: Problems and Solutions, vol. 5, no. 29, pp. $65-75$.

16. Azjmuk N. A. (2014) Transformacija procesu praci v informacijnij ekonomici [Transformation of the labor process in the information economy]. Social-Labor Relations: Theory and Practice, vol. 2, no. 8, pp. 217-223.

17. Balasynovych B. (2005) Vplyv informacijno-komunikacijnykh tekhnologhij na rynok praci i zajnjatistj naselennja [Influence of information and communication technologies on the labor market and employment of the population]. Ukraine: aspects of labor, no 1, pp. $30-34$.

18. Kamalova Ju. F. (2004) Osobennosti trudovogo posrednichestva na osnove sovremennyih informatsionnyih tehnologiy [Features of labor mediation on the basis of modern information technologies]. (PhD Thesis)/

19. Rjeznikova V. V. (2010) Pravove reghuljuvannja poserednyctva na rynku praci [Legal regulation of mediation in the labor market] University scientific notes vol.4 no.3, pp. 104-115.

20. Azjmuk N. A. (2015) Sutnistj, osoblyvosti ta funkciji cyfrovogho rynku praci [Essence, features and functions of the digital labor market]. Economy, vol. 5 no. 170 , pp. $38-43$.

21. Senokosova O. V. (2014) Setevyie institutyi ryinka truda [Network labor market institutes]. Economics Management Right, vol.14, no. 2, pp. 142-146.

22. Poshuky vakansiji v Merezhi: osoblyvosti virtualjnogho rynku praci Available at: http://forbes.net.ua/ua/opinions/1424726-poshuki-vakansiyi-vmerezhi-osoblivosti-virtualnogo-rinku-praci. (accessed 04 March 2018).

23. Oficijnyj sajt internet-birzhi "Elance" Available at: http:/www.elance.com (accessed 05 March 2018).

24. Nilles J. (1998) Managing Telework: Strategies for Managing the Virtual Workforce Available at: http://trove.nla.gov.au/work/7769072?q\&versio $\mathrm{nId}=8952146$. (accessed 04 March 2018).

25. T. W. Malone, R. J. Laubacher. (1998) The dawnofthe e-lance economy. Harvard Business Review. September-October 1998, Reprint 98508.

26. Online Work Report. United States, 2014 Full Year Data. Available at: http://elance-odesk.com/online-work-report-us (accessed 04 March 2018).

27. Global Freelancer Survey. Available at: https://www.elance.com. (accessed 05 March 2018).

28. Doslidzhennja servisom top \$ dev rynku autsors-proghramuvannja Skhidnoji Jevropy [Research by the service of top $\$$ dev of outsourcing programming in Eastern Europe]. Available at: http://topsdev.org/blog/obzor-rinka-freelance-2014. htm. (accessed 06 March 2018).

29. Doslidzhennja: universytety ta mista na rynku autsors-proghramuvannja Skhidnoji Jevropy [Research: Universities and cities in the outsourcing programming market of Eastern Europe]. Available at: http://topsdev.org/blog/ obzor-universitiesfreelance-2014.htm. (accessed 06 March 2018). 


\title{
CIVIL-LAW PROTECTION OF SUBJECTIVE RIGHTS IN THE INFORMATION SPHERE
}

\section{Guyvan Oksana ${ }^{1}$ \\ Sergienko Valeriy ${ }^{2}$}

DOI: http://dx.doi.org/10.30525/978-9934-571-29-9_3

\begin{abstract}
In this article, a study was made of the nature of relations in the sphere of information turnover. Some types of violations of the right to access to information and general features of legal protection of these rights have been clarified. A legal mechanism has been established for mediating the protection of the public and personal information space. Since special laws have been adopted that regulate the implementation of relations in the field of information, they only determine the nature of the unlawful acts, and do not establish sanctions for them, it indicates the lack of information and legal responsibility in the special legal acts as a legal category. Therefore, the perpetrators, as a rule, do not experience prosecution. In this regard, the doctrinal views of scientists on the possibility of the existence of civil liability without sanctions for violations in the form of the so-called obligation to give an account of their actions are examined. It is established that such moral responsibility is not related to protection and legal responsibility and has a regulative rather than a protective nature. The comparative analysis of efficiency and bases of application of measures of civil-law and administrative-legal reaction to offenses in the information sphere is carried out. The legal regulation of information relations in certain regulatory acts that regulate special relations, for example, on consumer protection, in advertising activities, has been studied. Numerous examples of the application of the general types of sanctions provided for in article 16 of the Civil Code for information infringements are presented as ways to protect personal non-property rights.
\end{abstract}

\footnotetext{
${ }^{1}$ Competitor,

Kharkov National University of Internal Affairs, Ukraine

${ }^{2}$ Candidate of Law, Professor,

Head of the Department of Legal Regulation of Economics, Kharkiv National Economic University, Ukraine
} 


\section{Introduction}

At all stages of human development, information was the object of lust. It was believed who owns the information, he owns the world. Indeed, the more information a person has, the greater strategic advantages he achieves in politics, business, and social activities. Therefore, it becomes quite understandable why many states view information as a strategic resource [1, p. 47]. Rapid technological progress in the information sphere puts society, legal science and the legislator in front of the need for effective legal regulation of social relations in this environment.

The issue of ensuring the human right to information is one of the main issues that are ensured and protected by international law. In particular, the freedom to seek, receive and impart information is one of the most important political and personal human rights and is included in the Universal Declaration of Human Rights (article 19). This right is also settled in Art. 10 of the European Convention for the Protection of Human Rights and Fundamental Freedoms. Ukrainian national legislation also pays much attention to this aspect. Article 34 of the Basic Law of Ukraine states that everyone has the right to freely collect, store, use and disseminate information verbally, in writing or in any other way - at his choice. The exercise of these rights may be restricted by law in the interests of national security, territorial integrity or public order in order to prevent disorder or crime, to protect public health, to protect the reputation or rights of others, to prevent the disclosure of information received in confidence, or to ensure the authority and impartiality of justice. Article 32 of the Constitution states that every citizen has the right to get acquainted with state information, local government bodies, institutions and organizations with information about himself that is not a state secret or another secret protected by law.

At the present stage of its development, the society has reached a level where its further progress largely depends on the proper state of information interaction of individual state, public institutions and individuals. Given the significant demand for information, the importance of turnover in this area, the very high relevance of the issue, the significant efforts both of the law-making and law enforcement branches of government, and doctrinal developments require the organization of proper legal support for these relations. This includes the need to formalize legal guarantees for the circulation of information, exchange of information, ways to improve this process, protect the media and the persons who disseminate it and use it. 
Particularly important is the need to establish, at a standard level, the main criteria that ensure the certainty of ownership of specific types of information and its carriers, the legal foundations governing access to it and the possibilities for limiting such access, legal guarantees of free circulation in the information sphere, a clear list of grounds for offenses and - necessarily - sanctions for such violations.

As the information communication in modern society acquires rapid development, especially in the field of public information and electronic communication, including international communication, the normative support lags behind the actual state of affairs, some aspects of legal relations remain insufficiently regulated. In particular, further improvement requires a legal mechanism to protect the public and personal information space. Now this problem has become an important factor not only information, but also general security at the individual, regional and global levels. So, for example, every year in the leading countries of the world not only the number of hacker virus attacks on computer networks is growing rapidly, but also the level of losses incurred to the owners and users of the information resource as a result of such actions by intruders. Therefore, the Ukrainian legal system, as well as international and foreign national practice of law enforcement, requires improvement, first of all, in the implementation and use of adequate means of legal responsibility. This will prevent large-scale negative social consequences, will contribute to the protection of basic human rights for information.

With the development of the information space in society, there is a significant growth of the relevant relations, and then of the offenses in this sphere. Meanwhile, national legislation does not pay enough attention to questions regarding the punishability of such acts. Therefore, we have to state the fact that there is no comprehensive development and implementation of information and legal liability as a legal category in special legal acts, therefore, the perpetrators, as a rule, are not held accountable. At the same time, the sphere of information legal relations, both in terms of their implementation and protection, requires a deep understanding, an adequate choice of methods and means of legal impact, constant adaptation and improvement, taking into account the acquired legal practice. Therefore, the problems of legal responsibility in the information sphere can not remain unnoticed among lawyers, scientists and practitioners. 


\section{Legal basis of responsibility in the information sphere}

The problem of legal responsibility for information offenses is an integral part of the system research of information security issues. The latter relate to the challenges of the humanitarian plan that occur in connection with unauthorized unauthorized access, uncontrolled use and dissemination of personal data, inaccurate information and thus interference in privacy; threats of a political and legal nature to preserve commercial and confidential data. As one of the elements of the general system of punishment for the committed offense, civil liability is intended to ensure the legal order established in the sphere of material civil relations by protecting the violated rights and interests of subjects of information relations with the use of precisely such means, which consist in additional material or organizational encumbrance of the offender. This may be the termination or change of relations, a fair property compensation to the victim as a result of a violation of his information rights.

The institute of civil liability for information infringements is due to the complex nature of the information law, separate norms of which are contained in civil law as a general form (CCU), and in special acts regulating purely information activities, or certain issues of material turnover, which are provided by information exchange in necessary for this volume. In civil literature it has been repeatedly pointed out that responsibility is, although important, but still only an element of negative consequences - sanctions applied to violators of subjective civil law [2, p. 9]. It is this civil-law regulation of the protection of subjective rights differs from criminal and administrative, where the role of sanctions is reduced to the exclusive application of liability measures.

The punishability of unlawful actions in relation to information occurs when an offense is committed. Information infringements are committed in a special plane of human activity - in the sphere of searching, creating, processing, transferring, receiving, storing, protecting and using any information about the surrounding world (information). Often they occur with the use of information tools and information technology, regardless of its form. Information infringement can occur also in other spheres of human activity. Important circumstances for the commission of such acts are the conditions of the information environment for their implementation, related to the use of information, information tools and technologies for working with information regardless of form [3, p. 132]. Civil-law sanctions for vio- 
lations in the information sphere, their type and effectiveness are due to the peculiarities of material relations based on the principles of inadmissibility of arbitrary interference in the sphere of a person's personal life, deprivation of property rights, freedom of information activities, judicial protection of civil rights and interests, etc., and also determined by the direction, seriousness of the violation, the presence of intent and the nature and extent of the damage caused.

As a protective legal institution, legal liability for violations in the information environment should be directed at solving important problems of legal provision of human and social interests in new information dimensions. The main directions of legal regulation should be formed taking into account the public need for implementation and protection of the right to information, protection of ownership of information and information products of intellectual property, protection of personal data, information infrastructures and networks, protection of non-material goods from dissemination of false information. This issue is very urgent, because with the rapid progress of information technology, the level of threats to information circulation is growing daily, so the need for a legal adequate response is obvious.

The right to information is inalienable for the bearer, allows you to freely own, use and dispose of it, that is, it has all the signs of ownership, which to a large extent distinguishes it from other personal non-property rights. In addition, any person has the right to access, that is, to use information as an object of material circulation that is owned or owned by others. These infringements can be directed against these infringements. For example, through unauthorized access, the right to certain types of information, in particular commercial secrets, copyright or patent rights, is violated. One example of illegal behavior in the information sphere is when the information manager denies access to information, wrongfully qualifying it as having access restrictions. Also, the conditions for the dissemination of information can be violated by the user when they are defined in the contract for the provision of information services, to which the parties undertake corresponding obligations, including the use and dissemination of information on the subject matter of the transaction.

The institute of legal responsibility for the commission of offenses in the field of information relations is a legal mechanism that is designed to ensure the effectiveness and effectiveness of law. Today it is extremely necessary for the consistency and stabilization of interactions in the daily life 


\section{Civil-law protection of subjective rights in the information sphere}

of Ukrainian society. Offenses in the information sphere are directed both to the information itself and to the information infrastructure. Therefore, some researchers theoretically substantiate the need to study the appropriate protective mechanisms within the framework of a single concept of an object of encroachment, having formulated it as an "information system" or "information object" - as a set of information contained in databases and information technologies and technical means that ensure its processing [4, p. 88]. Guided by methodological approaches, we can support this thesis. After all, despite the different essential nature of information and the means of its storage, transmission and processing, they as threats can be considered together. This will ensure greater coherence and coherence of normative developments in the field of protecting the information rights of the individual.

In general, the civil-law tools for protecting and protecting the rights of their bearers as a result of offenses in the information sphere, as well as in other areas of protection, is based on private-law principles of interaction of participants in relations based on equality of parties and disposition of constructing the content of relationships. At the same time, guided by the fundamental principles of constructing such relations, the legal doctrine and the relevant legislation go beyond the inadmissibility of arbitrary interference in the sphere of a person's personal life, inadmissibility of depriving the right to property, freedom of contract and business activity, judicial protection of civil rights and interests, and the like. If we ignore the general principle of constructing appropriate mechanisms for regulating relations, both in the regulatory and in the protective and legal context, and focus exclusively on their protective significance, it should be pointed out that civil protection must be exercised in case of violation of the private rights of their bearer. For example, civil liability as an element of negative consequences for the offender in the information sphere comes as a result of causing material or moral harm to individuals or legal entities in violation of the relevant information rights and is the need to compensate for the losses incurred.

In this sense, the sign of civil liability is compensatory and restorative nature, which manifests itself in the application to the guilty person of compulsory measures of a property nature aimed at compensating the inflicted losses to the injured party. But, the sanctions of civil protection of information rights of the individual are not limited only to their compensatory 
component. Legal protection may contain protection and legal requirements provided for by other clauses of Article 16 of the Civil Code or by special regulatory enactments. The choice of the punitive consequences of unlawful acts is often determined not only by the will of the victim, but also by the specifics of the implementation of the information law, the peculiarity of encroachment on him, the significance of negative consequences and the perception of such threat by the rightholder.

Thus, as a matter of fact, most of the normative and legal documents that are used to organize information relations can not be recognized as such that they regulate purely private legal relations, that is, they are in themselves acts of civil legislation. At the same time, considering that the legislator prefers the civil-legal method in regulating the consequences of infringement of the information rights of the individual (although it does not exclude the application of punitive norms of acts of other branches of law), the doctrine is dominated by the idea of the need for the most careful study of the civil aspect of the given problem [5, p. 38]. But, when studying the elements of private relations in essence, including taking into account the predominantly civil law ways of formulating and applying sanctions for their violation, it is necessary to take into account that unlike other material civil rights, in the implementation of information relations, , or not, there is always a certain public interest. In some cases, it can have frank manifestations, more often it is hidden behind other results of the relationship, but one way or another it takes place.

It is the presence of a public element in the structure of the right to information is, a factor that separates the mechanism of legal regulation of information relations from other private law. Therefore, at the current stage of the development of information relations and computer technologies that provide them, we can conclude that the need for special legal measures in this area is the main public interest, first of all. Therefore, legal regulation concerns not only and not so much the interests of persons involved in this area of social relations. The issue of collecting, storing, processing, providing and protecting information causes a social need for their solution. After all, the inability of the state to ensure the effective functioning of the institution of legal responsibility (to timely restore the violated rights of citizens, to compel state bodies and their officials to perform their duties, consistently, regardless of positions, ranks and ranks, apply appropriate measures of state influence to offenders) [6, p. 343]. 


\section{The legal nature of the information rights of the individual}

Actually, information human rights belong to the essence of personal non-property rights. Consequently, for their protection can not be used by far not all the legal means provided by law in the event of violation of real or mandatory rights of participants in legal relations. For example, based on the essence of the right to information, its carrier can not be defended by such means as collecting a contractual penalty, recognizing the right, restoring the situation that existed before the violation, and the like. Nevertheless, most of the legal protection mechanisms that are of a general nature are inherent in the protective sphere in the commented sphere. So, the subject has the right to present a requirement to the manager of information on the provision of information to him, this relationship has a public nature. Under the provisions of article 10 of the special law "On Access to Public Information", everyone has the right to access information about him that is collected and maintained. In turn, information managers possessing information about a person are obliged to provide it unimpeded and free of charge at the request of persons to whom it relates, except in cases provided for by law. If the administrator does not fulfill his obligation to provide public information within a period established by law, a person whose moral rights are violated in this way can present a judicial claim on the defendant's obligation to provide him with the requested information. Putting an appropriate decision by the law enforcement agency will essentially mean that the court has realized the plaintiff's right to defend his right by forcing the debtor to fulfill his duty in kind (Part 5, art. 16 of the Civil Code).

At the same time, the information manager may refuse to grant access to it only in the cases established for this purpose, for example, referring information to such that access to it is restricted. Therefore, in such a case, the question of the legality of such an act must be thoroughly investigated, including in the judicial process. The presence and sufficiency of legal and factual grounds for the recognition of certain information, for example, official, should be checked. And in the absence of such grounds or justifications, denial of access to public information is recognized by the court as illegal. For example, in resolving such a dispute, the Zaporozhye District Administrative Court noted that by refusing to provide a copy of the letter (instruction) on the grounds that this information relates to official information, the respondent failed to comply with the law requirements, since he did not apply the "three-syllable test" and did not I checked whether such a doc- 
ument has information, access to which is not limited. In other words, if the request for obtaining public information contains a requirement to provide a document containing information with limited access (that is, to which the "three-syllable test" applies), the respondent as a subject of power is obliged according to part 7 of article 6 of the Law of Ukraine "On access to public information "to provide information, access to which is not limited, if in general the document containing the requested information can not be provided. However, the respondent did not comply with the requirements of the law, since the hamper completely refused to satisfy the request for public information, arguing that the requested information was official [7].

In spite of the fact that information rights do not have property content, for their legal protection civil-law tools, inherent for protective property relations, in particular for property rights, can be used. This is explained by the fact that, in some cases, information legal relations are of an absolute nature. Therefore, the right of the person who owns the information or that owns the information, as well as the right of the bearer of corporeal law, corresponds to the obligation of an indefinite circle of persons. At the same time, this duty consists in the passive behavior of the obligated subjects. They should not prevent the right holder from exercising his powers at his own discretion, freely choosing the ways of exercising his right: to freely disseminate information, collect it, store it and so on. In view of the foregoing, such ways of protecting information rights, such as prohibiting a third party from taking actions to create obstacles to the exercise of the right, when there is a significant probability of such a violation (preventive protection), eliminate the violations that create such obstacles (like negator protection) look quite acceptable.

According to the legislator's classification, information as an object of civil rights is determined by one of the types of non-material goods (Article 200 of the Civil Code). However, it is not difficult to see that this object has such essential distinctive dimensions, which radically distinguish it from the majority of such objects. In particular, personal intangible goods are therefore called personal, which belong exclusively to the bearer of law, can not be the object of transfer (inalienable). The law does not regulate the order of their creation, change and termination, their specificity to a certain person, as a rule, has a limited period, which is measured by the duration of his life. But almost every measurement of the essence of information as an object of civil law regulation is different from the general manifestations. 
Therefore, information relations, in principle, go beyond the legal regulation provided for by legislation to mediate situations to ensure the implementation and protection of intangible goods. For example, a special legal mechanism should establish the specifics of the definition and procedure for establishing ownership of certain information, including monopoly and other rights for its storage, distribution, protection.

The most significant feature of information that radically distinguishes it from other non-property rights of a person is its multifaceted and comprehensive character. No sphere of human activity, including those that have the appropriate legal support at the present stage, can even be imagined without an information component. In Art. 18 of the Law of Ukraine "On Information" describes the main types of information: statistical, mass, on the activities of state authorities and local self-government bodies, legal, about the individual and the like. As you can see, the list is far from exhaustive, and this is understandable. Therefore, even when all information relations that are currently available are established and subject to legal regulation, rapid changes in real life will cause new information and exchange situations and the need for their resolution. At the same time, taking into account special information activities regimes in order to ensure state and public interests, there is an objective need to introduce special ways of dissemination and use of information.

\section{The state of the legal regulation of the protection of information rights}

In Ukraine, special laws have been adopted that regulate the implementation of relations in the field of information. The new version has the Law of Ukraine "On Information", in May 2011 the Law of Ukraine "On Access to Public Information" came into force, the Law of Ukraine "On Protection of Personal Data" was adopted. With the development of the information space and turnover in society, there is an increase in the scope of legal relations in the information sphere. It is logical that under such conditions, the number of violations of the rights of participants in information circulation and legislation, which mediates information relations, is growing. At the same time, one should agree with the opinion expressed in the literature on the absence of the elaboration of information and legal responsibility as a legal category in special legal acts, therefore, the perpetrators, as a rule, do not experience liability [8]. 
Indeed, special legislation. such as the Law of Ukraine "On Information", the Law of Ukraine "On Protection of Personal Data", the Law of Ukraine "On Access to Public Information", the Law of Ukraine "On Television and Radio Broadcasting", establishes cases when the commission of certain actions is considered unlawful. Let's say, under the instruction of Art. 9 of the Law of Ukraine "On access to public information" and Art. 29 Law "On Information" information managers may classify information as restricted in access only under certain circumstances. The logical construction allows to conclude that in the case when access restrictions occur in the absence of factors determined by law, such actions of the steward are illegal. Under the provisions of Article 24 of the Law of Ukraine "On Access to Public Information", the perpetrators of such violations, as not the provision of a response to a request; Do not provide information on request; unreasonable refusal to satisfy the request for information; not disclosure of information in accordance with Article 15 of the Law; provision or disclosure of inaccurate, inaccurate or incomplete information; untimely provision of information; unreasonable referring of information to information with limited access; failure to register documents; deliberate concealment or destruction of information or documents, are liable for violation of the law on access to public information. But, unfortunately, the content of specific sanctions for these violations remains uncertain.

Now in Ukraine there are many information regulatory legal acts, and their number is constantly growing. But, as the scientists correctly note, quantitative growth does not always ensure a qualitative growth. Therefore, we have such problems with the state of the current legislation as its unsystematic development, internal contradictions in the regulation of various social relations, the unsettledness of many social relations, a disproportion in the correlation between laws and by-laws in favor of the latter, insufficient scientific justification, declarativeness and lack of address of legislative acts, lack of mechanisms for their implementation in these acts [9, p. 42]. These problems are inherent in all branches of law, and not only regulatory regulations governing information relations. But in the latter, such shortcomings are quite significant and indicative because of their intersectoral and comprehensive nature.

Individual researchers in more detail determine the list of problems with regard to the legal regulation of information relations. Among them stand out such as a large number of laws and subordinate regulations in the field of 
information relations. which makes it difficult to find, analyze and agree on them for practical application; absence of a legal, clear, hierarchical system of legislation, which leads to a contradictory interpretation when applying the norms in practice; inconsistency of the conceptual apparatus, incorrectness of certain terms that do not cause appropriate information reflection or do not have a clear definition of their content; terminological inaccuracies, a different interpretation of identical in name and form of concepts and categories, which leads to ambiguous understanding and their application in practice. To the problematic issues in the sphere of the existing legal support of information processes in the society should also be attributed the differences in understanding the structure and composition of the system of legislation and approaches to their formation [10, p. 110].

The legislation of Ukraine on information also includes normative legal acts that mediate relations in individual sectors and are not always of a civil nature, but have an information component that determines the types, forms and means of providing and receiving information that ensures the proper implementation of basic material relationships. In these relations, information exchange is not basic, but auxiliary character, which, however, guarantees the effectiveness and effectiveness of the main legal relations. So, the legal responsibility in the information sphere, which is established by numerous special laws in many spheres of activity, is somehow connected with the turnover of information. For example, in Art. 15 of the Law of Ukraine "On Protection of Consumer Rights" stipulates the consumer's right to information and determines the content of such information. As a sanction for not providing or providing untrue information (about the goods, and about the manufacturer (executor, vendor), the way of using it, about the corresponding risks, etc., which entailed the acquisition of products that do not possess the necessary properties), the consumer is granted the right terminate the contract and demand compensation for losses caused to it. When, as a result of providing inaccurate, incomplete or untimely information about the product and the manufacturer, this caused a threat to the life, health or property of the consumer, the victim has the right to present to the seller (manufacturer, executor) the civil legal requirements provided by law, and also to demand damages, The damage caused to the ego by health, as well as natural objects that are in its possession on the basis of ownership or on other grounds provided for by law or by contract. Compensation in full is subject to losses caused to the consumer by unfair advertising. 
Actually, both national, foreign and international law was blocked by a large set of regulatory material regulating information relations in two separate legal units. The first of them regulates the legal mechanisms for access to and disposition of information. In this sense, we are talking about the legal support for the realization of the subjective right of a person to obtain the possibility of its implementation through the proper performance of a public debt by the information manager. For example, in this way, the result is obtained of obtaining reliable information about the subject due to the proper fulfillment by the distributor of the obligation to verify its reliability (Article 302 of the Civil Code). We are talking about the so-called "positive" freedoms in the sense of realizing the "right to information" by implementing by the obliged person specific positive actions aimed at realizing the subjective right of its bearer. In this way, the right to receive information is realized (Article 302 of the Civil Code); the right to information about their state of health (Article 285 of the Civil Code); the right to reliable information about the state of the environment (Article 293 of the Civil Code); the right of a participant in an economic company to receive information about the activities of the company (Article 116 of the Civil Code); the passenger's right to information about transport and its movement (Article 911 of the Civil Code); the right of a participant in a simple partnership agreement to familiarize himself with all documents on the conduct of common affairs of participants (Article 1136 of the Civil Code); the consumer's right to information about products (Article 4 of the Law of Ukraine "On Protection of Consumer Rights"); the right of the buyer to receive information about the goods (Article 700 of the Civil Code); the right of the customer to receive information from the contractor on the progress of work and (Article 861 of the Civil Code), and others.

Another set of legislative acts is aimed at protecting information, ensuring confidentiality and controllability of certain information. This in the literature is called the process of realizing "non-violent" freedoms, which are the content of the right to preserve and protect information, in particular the protection of its sources and carriers, of certain types of information that have limited access. Such are the rules on confidential information, the right to inviolability of business reputation (Article 94, 299 of the Civil Code); the right to a secret about the state of health (Article 286 of the Civil Code); the right to the secret of donation (Article 290 of the Civil Code); the right to privacy of personal life (Article 301 of the Civil Code); the right to 
confidentiality of correspondence (Article 306 of the Civil Code); property rights of intellectual property for commercial secrets (Article 506 of the Civil Code); the right to bank secrecy (Article 1076 of the Civil Code); the right of the proprietor of production for the non-disclosure of the secrets of production, other confidential information received by the user (Article 1121 of the Civil Code). This approach seems reasonable and rational. It is within these criteria that further law-making in the field under investigation should be developed. This will make it possible to achieve greater coherence and consistency of prescriptions due to the similarity of the regulated relations and their orientation.

\section{The civilized approach to information protection}

It should be noted that among scientists conducting research on this issue, there is still no unanimity regarding the legal nature of the main features of information and information relations as the subject of legal regulation. Attempts to reach a consensus in this regard have been repeated many times, so it is necessary to note their sufficient effectiveness. Scientists have established such characteristic features, which, in general, are inherent in the relations in the commented sphere, as systemic, selective, substantial non-independence, continuity, inexhaustibility, mass character, property to transform, ability to limit, universality, quality, and others. These scientific developments contribute to the allocation of information relations in a certain group identified by the nature of the occurrence, the methods of implementation, the scope of rights and duties and methods of legal protection, which allows for their specific regulation. At the same time, not only the peculiarities of these relations are noted, in fact, which causes certain differences from the general methods of regulation, but also emphasizes the difference in the legal nature of the relationships within the system that can be qualified as information. First, it is proposed to separate purely information relations, which are directly related to the implementation of the powers of the person to receive, distribute. the exchange of information, the exercise of property rights over it, the protection of information resources, etc., and the relations that develop in the implementation of other substantive rights, but for their proper implementation require the involvement of certain information interactions (for example, obtaining information about the goods that are acquired ). These relations should be qualified as those that relate to information. Also, in the legal science it is proposed to meth- 
odologically distinguish between the concepts "information" and "knowledge" [11, p. 41], which is also worthy of attention.

In turn, given that the concept of "information" is very widespread in all respects in society, which are not always of a legal nature, but have an ordinary, personal design, the study of its content has historically been carried out on the basis of philosophical, sociological and cultural concepts on perception of a particular person and society the significance of this phenomenon and the realization of its essence. Expanding the empirical and applied scientific base within the methodologies of natural science disciplines, information was considered as one of the manifestations of the objective motion of matter in space and time. It was in this, in the opinion of the researchers, that the essential attribute value of information was manifested. Consequently, in the scientific and philosophical sense, information is a measure of certainty, organization, order. Difficulties and diversity of matter as phenomena can be perceived and understood by individual actors and society at the same time, thereby achieving certainty and organization in society. Information is associated with another common property of matter - reflection, according to this thesis information can be treated as the content of the reflected process or as an invariant part of the mapping, which can be defined and transferred from one system to another. The practical application of this scientific conclusion is the need to ensure information security in the sphere of social relations by preserving the social interactions of various sociocultural systems [12, p. 40-42].

Information as an object of civil law relations manifests itself in two ways. First, it is a commodity, therefore it is possible to implement information rights and corresponding responsibilities, and consequently, offenses, can be carried out in the field of mandatory legal regulation, including contractual legal instruments. So it is quite an acceptable measure of responsibility to recover penalties for failure to fulfill a certain debt to provide information, if it is provided for in the contract. Also, when the contract for the provision of information services is defective, specified in art. 218-236 CCU (for example, it contradicts the law or moral principles of society, is fictitious, etc.) it can be recognized as invalid. Secondly, information is attributed by law to a variety of personal non-property rights. Consequently, it is of a private nature and is an object of ownership. In such a case, the right to information is absolute and subject to protection using mechanisms inherent in both intangible goods and absolute proprietary rights (property rights). 


\section{Civil liability for violations in the information sphere}

To begin constructing a civil protection and legal mechanism that provides the very foundations of its existence, coordination and coordination of individual components, it is first of all necessary to determine the question of what an information offense is as an illegal act that threatens subjective information rights. In Ukrainian civilization, the formulation of this definition was made by scientists such as Yu.E. Maksimenko and V.A. Lipcane. They postulate information offenses as a socially dangerous, unlawful, guilty act for which tort law in the field of information provides for legal responsibility. Strictly speaking, such an offense is a guilty act of the subject, entailing information and legal responsibility $[13$, p. 251]. Completely agreeing with the postulate that the violation of information rights is an unlawful, guilty (intentional or careless) action or behavior that infringes upon the public relations established by the law arising from the implementation of information activities (receipt, use, dissemination and storage of information) [14, p. 57], we can not yet support the position that civil penalties for such offenses are reduced solely to the application of liability measures.

The variability of the understanding of civil liability is due to the fact that it is an important, but not the only, instrument of civil law that ensures the protection of private legal relations, including information. Therefore, responsibility is traditionally considered in interrelation and correlation with other measures of protection of civil rights [5, p. 38-39]. Protection of the infringed information rights of the person can be carried out by other means with application of sanctions which do not concern responsibility. For example, in the event that the information manager does not provide access to public information as a result of an unlawful decision to restrict access, such a decision may be declared invalid, or if the person refuses to provide information about his personal data processed, such information may be claimed compulsorily. Such protective and legal remedies are provided for in Art. 16 of the Civil Code (part 10 - illegal recognition of decisions, actions or omissions of the authority, or part 5 - enforcement of duties in kind), they are civil protective sanctions, but do not have the status of responsibility, since they do not burden the undue debtor in addition. Actually, the application of such sanctions does not release the latter from the obligation to compensate for harm if it comes to the right holder as a result of the offense, that is, to incur material liability. 
For this reason, we also can not agree with the thesis that the civil liability of acts that are classified as information infringements comes only in accordance with the norms of tort law. It is hardly correct that the position according to which civil liability in the information sphere comes as a result of causing material or moral harm to individuals or legal entities in violation of the relevant norms of information law and is the need to compensate for the losses incurred. Such an approach does not reproduce all the prerequisites and legal consequences with regard to the exclusivity of civil liability as compensatory and recovery results, manifested in the application to the guilty person of compulsory measures of a property nature aimed at compensating the inflicted losses to the injured party.

It is impossible to limit the use of sanctions, including - measures of responsibility, only in cases when, as a result of non-observance of the relevant norms of information law, damage is inflicted on enterprises, institutions, organizations and citizens. Indeed, according to the rules prescribed in the tort norms of Ukrainian laws, in particular, in Ch. $82 \mathrm{CCU}$, art. 22 of the Law of Ukraine "On Protection of Consumer Rights" refers to the need to compensate for harm caused by the wrongful actions of its culprit, including damage due to failure to provide or provide inaccurate or incomplete information. But this way of civil protection is far from exceptional. For example, in Art. $659 \mathrm{CCU}$ provides that a buyer who has not been informed of the rights of third parties to the purchased item has the right to demand a reduction in the price, a consumer who has not received proper information about the goods may demand the termination of the contract (Article 15 of the Law on Protection of Consumer Rights), and in the case when information disseminating information damaging the honor, dignity or business reputation of a citizen is disseminated in the mass media, they must be refuted in the same mass media (Article 37 of the Law of Ukraine "On print media in Ukraine", Art. 277 CCU).

Protective legal relations are not confined to liability alone, but cover other cases related to the protection of law [15, p. 15]. Along with responsibility, there are other consequences unsuitable for the offender, aimed at protecting subjective civil law. In civilization, they are called the means (measures) of the protection of law [16, p. 83-85]. They apply to the offender regardless of his guilt and restore the property position of the person or stop the illegal action. Responsibility is always associated with additional burdens on the offender, and with other ways of protecting the rights of such 
encumbrances there. So, unlike administrative or criminal legal relations, the protection of violated civil rights occurs not only through the application of measures of responsibility. For example, payment of forfeit and compensation of damages does not relieve the obligated person from the performance of the obligation in kind. The actual implementation is aimed at the fulfillment of the action that is stipulated by the content of the obligation, while the responsibility is directed towards fulfilling the additional debt that arose as a result of the offense [17, p. 445]. Responsibility and other types of protection of rights differ among themselves also, guided by the principle of guilt. In particular, responsibility under the general rule comes only for the person's guilty actions, while other civil penalties are applied on the basis of the principle of infliction. Consequently, responsibility is a narrower concept than legal remedies. Civil liability is a type of sanction and is an impact on the offender by depriving him of certain property rights or imposing additional property obligations on him [2, p. 9]. The most striking example of additional burdening as a measure of responsibility is the obligation to compensate for the damage or harm caused. For example, it occurs if, as a result of the publication of unreliable information, the reputation of the business entity has been damaged. The amount of responsibility of the guilty person in such a case is determined by the amount of losses. Means of responsibility are manifested in the consequences of a breach of an existing obligation (contractual liability) or in the consequences of the offense itself, generate a new liability (tort liability). At the same time, measures to protect the subjective law, including legal liability, should be economically justified [18, p. 5].

In the scientific literature the so-called concept of coercion is vividly discussed, according to which coercion is an obligatory manifestation of responsibility. The value of coercion is assessed differently both in the plane of its direct application and for its actual normative consolidation as a legal possibility. Some scholars have criticized the possibility of covering the concept of a voluntary implementation of an overdue debt [19, p. 33]. Others are convinced that the more effective effect is provided by the very possibility of using coercion, because it disciplines the participants in the relationship and creates prerequisites for the voluntary fulfillment of protective obligations, for example, compensation for harm [20, p. 13]. We consider the latter concept to be more balanced and correct.

Taking into account the practical lack of regulations on specific types of information responsibility in the sectoral acts mediating information rela- 
tions, we must be guided by common civil principles. At the same time, it should be borne in mind that the commented sphere of relations in some cases has diversified formations, therefore information responsibility can be realized in the planes of administrative, criminal and disciplinary punishment. Consequently, the concept of information and legal responsibility covers the implementation of legal instruments that are inherent not only in the civil, but also in other branches of law.

Negative legal consequences for a person who violated a certain information legal relationship, differ depending on the method of obtaining and using information. In some cases, information is used by a person for personal consumption, replenishing his knowledge. When such actions are unlawful, the consequence may be an obligation to stop such encroachment. This applies, for example, to unauthorized access to copyright objects, databases, etc. If certain official information (for example, protected by patent law) is illegally used to improve the production process, create new technological developments, in other words, the illegal acquisition and use of such information is carried out with a view to achieving a specific economic result, the emphasis in the application of sanctions should be made on compensatory liability - ii damages and compensation payments.

Civil law also defines special mechanisms for regulating the relationship in terms of coverage and disclosure of information in the media. In case of violation of these rules, the media becomes responsible. It consists in the fact that when a non-pecuniary harm is caused to an individual as a result of dissemination through the mass media of data that do not correspond to reality, those that humiliate the honor and dignity of a citizen, such damage is compensated by a court decision by the appropriate mass media, as well as by high officials and citizens. The amount of compensation for moral damage in monetary terms is determined by the court. At the same time, the duty to prove one's right lies with the defendant - the subject who committed the relevant infringement infringement. Also, the person who disseminated false information must refute them publicly. In addition to refuting inaccurate information and other, provided by Art. $277 \mathrm{CCU}$, ways to protect an individual whose personal non-property rights are violated as a result of the dissemination of unreliable information about him, protection can be exercised by other legal means. For example, in Art. $278 \mathrm{CCU}$ provides for a special protection method, such as the prohibition (termination) of the dissemination of information violating personal non-property rights. 
The need to introduce this method of protection is explained by its considerable effectiveness, including in the preventive plan. It is a normative provision that if a personal non-property right of an individual is violated in a newspaper, book, movie, television program, etc., which are prepared for publication, the court can prohibit their release until it is eliminated, and if they already issued, the court can prohibit (stop) their distribution until the violation is eliminated. If the elimination of the violation is not possible, it is allowed to seize the circulation of newspapers, books, etc. with the aim of destroying it.

At the same time, it is nevertheless necessary to note the decisive role of civil-law protection of the infringed information rights of the individual precisely by compensating for losses or damage that occurred to the victim as a result of the illegal actions of the counterparty. This is the only option for the use of an equivalent compensation mechanism, while the vast majority of infringements on information human rights can be stopped or prevented through the means of responding to other sectoral accessories. At the same time, the presence of harm is a prerequisite for the use of a legal instrument for compensation of the harm caused. The compensation mechanism is aimed at ensuring the most complete reimbursement of the material consequences of the violation of rights at the expense of the person who caused the harm, or other persons on whom, in accordance with the legislation, the duty of compensation for harm is entrusted.

Specificity of compensation liability for information offenses is due to the peculiarities of the object of the offense, the methods of calculation and proof of harm, and the like. In principle, the application of this responsibility is to impose on the offender the obligation to reimburse property or moral damage caused by violation of the norms of the information legislation. At the same time, an important feature of this protective-legal relationship is its universality. This means that a person can resort to it in all cases of violation of subjective civil rights (both in relative and in absolute legal relationships), even though there is no direct mention of this in a special rule of law or in a treaty. In addition, the right holder may, along with compensation for damage caused as a result of the violation, also apply other civil sanctions. So, despite the large number of measures of civil liability as a means of protecting civil rights in the information sphere, compensation for damages plays the role of the leading way of punishing the offender, and the amount of such sanction is calculated in monetary terms. 


\section{Conclusions}

From the study, we can draw certain conclusions. Information relations permeate all spheres of social relations. Being the only resource of interaction, they ensure proper organization of material processes, effective management of them. This greatly complicates the classification of unlawful acts in the information environment, which, in turn, hinders the complex legal provision of information relations, in particular in the sphere of their protection and protection. Taking into account the constant spreading of the spectrum of offenses, it is necessary to develop the concept of an information offense and to fill it with clear content, separating the criminal, administrative, civil, disciplinary responsibility for the object of encroachment, the way and direction of encroachment, the severity of social consequences. It is also necessary to establish as punishable acts aimed at violating other human rights (non-informational character) with the misuse of information, technology or information infrastructure.

The main features of the relevant legislation are the plurality of sources, the dominance of by-laws in the mechanism of legal regulation, the complexity of norms, their instability and the dynamism of acceptance. However, it should be noted significant shortcomings in the formation of an appropriate legal framework. Conceptually they are manifested, first of all, in fluctuations from the need for urgent and special regulation of information relations that are only being formed, to proposals for creating a single codified act that would regulate all existing relations in this sphere. It is impossible to agree with extreme positions, it is necessary, taking into account the complex nature of relations on information turnover, to further develop the relevant legislation in those directions that have historically developed: the implementation of information rights of the individual and the provision of information protection mechanisms. As for the basic, conceptual issues of the development of national legislation in the commented sphere, they should certainly be directed, first of all, to definitive consolidation of fundamental, basic concepts that are intensively used by the legislator in normative legal acts, their use. For example, one should provide legislative unambiguity with such a definition as "secret", "document" and "documented information", "service information", "automated system", "subject of information relations", "information relations system", etc.

Information has its specific characteristics, which reflect its internal nature and essence, influencing the choice of ways to protect information 
rights. Taking into account the peculiarity of information as an object of legal regulation, legal science needs to develop new legal means of response based on an analysis of real threats and risks in the information environment. This will make it possible to eliminate existing gaps in the legislation as soon as possible, since, due to rapid technical progress, unfortunately, the number and level of threats is increasing. As the first and necessary step, the need to harmonize the mechanisms of civil-law protection of information, which are introduced by various acts and continues to have a contradictory character, is seen.

The issue of responsibility for the violation of the information rights of the individual is primarily mediated by the general methods of legal protection prescribed in many acts of Ukrainian legislation. So, such means as termination of an offense, compensation of the caused damage, collecting penalties from the infringer and so on are applied. At the same time, given the extreme prevalence of information relations in all spheres and branches of legal social relations, we can assert that the range of types of sanctions should be broadened at the expense of specific safeguards inherent only in a specific offense. For example, in the case of improper or illegal use of information acquired in a legal way (in fact, if the right is abused), such a way of response as deprivation or restriction of the law may be offered.

Protection of violated subjective rights of a person in the field of information relations in civil law is exercised through the application of sanctions provided for by both article 16 of the Civil Code and other protective norms of liability and proprietary rights. This is especially evident when protecting and protecting such a specific object as information. At the same time, individual protection elements, such as liability, other remedies, have different grounds for application, different meanings and methods of influence. The possibility of ensuring state enforcement, which is carried out by the law enforcement agency, does not in any way eliminate the availability of other means of protection of the violated or contested right. Public interests do not create the need for any case of a civil offense to necessarily apply to bodies with jurisdictional powers. The state can provide an opportunity to exercise the right to the bearer himself, establishing the appropriate framework for appropriate actions, or provides the conditions for the voluntary fulfillment by the debtor of a protective and legal duty. 


\section{References:}

1. Alieva M.F. (2012). Informatsionnaya bezopasnost kak element informatsionnoy kultury [Information security as an element of information culture]. Vestnik Adygeyskiy gosudarsvenny universitet Seria 1: Regionovedenie, philosofia, istoriya, sotsiologiya, yurisprudentsiya, politologiya, kulturologiya no. 4 (108). Pp. 47-52.

2. Krasavchikov O.A. (1973). Otvetstvennost, mery zaschity i sanktsii v sovetskom grazdanskom prave. [Responsibility, protection measures and sanctions in Soviet civil law]. Problemy grazdansko-pravovoy otvetstvennosty i zaschity grazdanskih prav. Sverdlovsk, no. 27. pp. 5-16.

3. Polushkin O.V. (2009) O ponyatii informatsionnogo pravonarusheniya [On the concept of information offense]. Rossiysky yuridicheskiy zurnal. No.3. pp. 207-210.

4. Aristova I.V. (2000). Derzhavna informatsiyna polityka: organizatsiyno-pravovi aspekty: monografia. [State Information Policy: Organizational and Legal Aspects: Monograph] For Collegiate. Ed. O. M. Bandurka. Kharkiv: University of Internal Affairs. 368 p.

5. Tikhomirov O.O. (2015). Tsivilno-pravova vidpovidalnist za informatsiyni pravoporushennya: zagalnoteoretychni aspektu. [Civil liability for information violations: general theoretical aspects] Porivnyalno-analytichne pravo [Electronic scientific and professional edition]. No. 2. pp. 37-40.

6. Bezkluby I., Bobrovnik S., Gritsenko I., etc. (2014) Vidpovidalnist u pravi: philosofia, istoriya, theoriya. Monografiya. [Responsibility in law: philosophy, history, theory: monograph]; per community Ed. I. Bezkluby. Kiev. Gramota, 448 p.

7. Decision of Zaporizhia Regional Administrative Court of April 18, 2016 in case number 808/1093/16 URL: http://www.reyestr.court.gov.ua/Review/57258225.

8. Stadnichenko D.V. Administratyvna vidpovidalnist za informatsiyni pravoporushennya. [Administrative liability for information violations]. URL: http://legalactivity.com.ua/index.php?Itemid=122\&catid=98\%3A20514\&id= 811\%3A260414-13\&lang=en\&option $=$ com_content\&view $=$ article $\quad($ accessed 20 February 2018).

9. Shemshuchenko Yu.S. (1996) Theoretychny zasady kotseptsii rozvytku zakonodavstva Ukrainy. [Theoretical principles of the concept of the development of Ukrainian legislation]. The Concept of the Development of Ukrainian Legislation: Materials of Sciences. Conf., / Institution of Legislation of the Verkhovna Rada of Ukraine. - Kyiv, pp. 42-44.

10. Tsimbalyuk V.S., Gavlovsky V.D., Grishchenko V.V. and others. (2004). Osnovy informatsiynogo prava Ukrainy: Navchalny posibnyk. [Fundamentals of Information Law of Ukraine: Textbook]. Ed. M.Ya. Shvets, R.A. Kalyuzhny and P.V. Melnik. Kyiv: Znannya, 274 p.

11 Bachylo I.L, (2001). Informatsionnoe pravo: Uchebnik. [Information Law: Textbook] I.L. Bachilo, V.N. Lopatin, M.A. Fedotov, Ed. B.N. Topornik. St. Petersburg: Legal Center Press, 789 p.

12. Khitarova I.Yu. (2008). Duhovnaya zhizn obschestva kak obekt informatsionnoy bezopasnosti. [Spiritual life of society as an object of information security]. Etnosotsium i meznatsionalnaya kultura. No. 6. pp. 37-47. 
13. Lipkan V.A., Maksimenko Yu.E. (2013). Zasady rozvitku informatsiynoyi deliktologiyi. [Principles of Development of Information Delictology]. Pravo Ukrainy. No. 10. pp. 249-256.

14. Pisarenko G. M. (2016). Yuridychna vidpovidalnist v informatsiyniy sferi: okremi aspekty stanovlennya. [Legal responsibility in the information sphere: separate aspects of formation]. Naukovy visnyk Uzgorodskogo natsionalnogo universitetu. Seria "Pravo". V. 2, pp. 55-58.

15. Orlova E.A, Nosov V.A. (1983). Ohranitelnye grazhdansko-pravovye normy i pravootnosheniya. [Protective civil law norms and legal relations]. Proceedings of the Materialno-pravovye i protsesualnye problemy zaschity subektivnyh prav. Interuniversity thematic collection. Yaroslavl. Yaroslav. state. university. Pp. 10-18.

16. Tsivilne pravo Ukrainy: Akademichny kurs. Pidruchnyk. [Civil Law of Ukraine:Academic Course. Textbook]. In 2 volumes / per eng. Ed. Y.M. ShevchenkoV. 1. General part. Kyiv: Publishing House "In Yure", 2003. 520 p.

17. Kharitonov Ye.O., Startsev O.V. (2007). Tsivilne pravo Ukrainy: Pidruchnyk. [Civil Law of Ukraine: Textbook]. Issue 2, reb. and listens. Kyiv: Istina. 816 p.

18. Butnev V.V. (1990). Yuridicheskaya otvetstvennost i pravovoe gosudarstvo. [Legal responsibility and the lawful state] Proceedings of the Legal responsibility: general problems and branch features. Far Eastern State University. Abstracts of the inter-university conference of young jurists. Vladivostok: FENU, pp. 4-5.

19. Bratus' S.N. (1973). Spornye voprosy theorii yuridicheskoy otvetstvennosti [Controversial issues of the theory of legal responsibility]. Sovetskoe gosudarstvo i pravo. No. 4. pp. 27-35.

20. Tarkhov V.A. (1973). Otvetstvennost po sovetskomu grazhdanskomu pravu. [Responsibility for Soviet civil law]. Saratov: The Saratov University Publishing House, 1973. 456. 


\section{THEORETICAL-LEGAL AND APPLIED ASPECTS OF THE NOTARIAL PROCEDURE CONCERNING THE CERTIFICATION OF WILLS}

\section{Dolynska Mariia ${ }^{1}$}

DOI: http://dx.doi.org/10.30525/978-9934-571-29-9_4

Abstract. The article deals with the comprehensive analysis of implementing the notarial procedure concerning the certification of wills in Ukraine. Special attention is paid to the definition of the concept of wills. The author carried out the classification of wills according to the procedure of certification and the subjects entitled to certify the will. The purpose of the research is a comprehensive scientific-theoretical and practical analysis of the features of the legal regulation of the notarial procedure concerning the certification of wills. The tasks of the research are to determine the concept and types of wills, to carry out the characteristic of legal principles of certification of wills, to investigate the features of certification of wills. The subject of research is the theoretical achievements and modern practical tendency of the interpretation of the legal regulation of the notarial procedure concerning the certification of wills. The author applied general scientific and special methods of investigation, in particular: system, structural-functional and comparative methods. The issues of the restriction of the right to certify the wills are scrutinized. Analyzing the question of keeping the secrecy of notarial acts, the author proves that the fact of the violation of the secrecy of the will does not entail declaring the will invalid. The author emphasizes the fact that during certifying the wills, bodies of notariate and quasi-notariate should strictly adhere to the norms of the current legislation. The procedure of the certification of wills, including the wills that equal to notarial, is investigated in detail. In the current legislation the author proposes to establish the procedure for the substitution of the public individuals and official persons authorized to certify wills that equal to notarial. A will is a unilateral transaction, which is executed in writing with indication of the place and time of its construction, the information about the testator: the surname and name, patronymic name

${ }^{1}$ Doctor of Law, Associate Professor,

Head of the Department of Economic and Legal Disciplines,

Lviv State University of Internal Affairs, Ukraine 
(if there is); the registration number of the discount card of the taxpayer in accordance with the State register of natural persons - taxpayers or the reason of its absence; the place of residence or location; the date and place (if it is unknown-the name of the country) of birth, personally signed by the testator and certified by a notary or specially authorized officials.

\section{Introduction}

In Ukraine the persons specified in the will - that is the persons appointed in accordance with the will of the testator, have the priority right to succession. In default of the will, declaring it null and void, non-acceptance of inheritance, or refusal to accept by the testamentary heir (testamentary succession), the heirs have the right to legal succession (according to law).

Authorized bodies of notariate and quasi-notariate have the right to make and certify wills. The specified bodies of notariate must promote the exercise of rights of natural persons and legal entities, the protection of legitimate interests, and explain their rights and obligations. Problems of legal regulation of certifying the wills are one of the subjects of discussion, especially today, when the fundamental changes, due to the undeclared war and the actual occupation of the East of Ukraine, take place in the society. It is necessary to solve a number of problems standing before the public individuals and official persons authorized to certify wills that equal to notarial in the process of their testamentation. It is a question of urgent importance, because it will allow analyzing the normative and legal acts and their gaps concerning the notarial procedure of the certification of wills. Conclusions of the research will contribute to improving the notarial procedure of the certification of wills.

The purpose of the research is a comprehensive scientific-theoretical and practical analysis of the features of the legal regulation of the notarial procedure concerning the certification of wills.

The tasks of the research are to determine the concept and types of wills, to carry out the characteristic of legal principles of certification of wills, to investigate the features of certification of wills.

The object of the research is the legal regulation of the notarial procedure concerning the certification of wills.

The subject of research is the theoretical achievements and modern practical tendency of the interpretation of the legal regulation of the notarial procedure concerning the certification of wills. 
The question of the formation of the Ukrainian notariate was the subject of study of many scientists. In particular, the issue of the proceedings in the notarial procedure, including the issue of the certification of wills, was investigated by such scientists as: V. Barankova, N. Vasylyna, M. Diakovych, Yu. Zaika, V. Komarov, M. Matsehora, A. Nahorna, O. Nelin, S. Fursa, Ye. Fursa, Ye. Kharytonov, O. Kharytonova and others. However, these scientists did not pay enough attention to the notarial procedure concerning the certification of wills.

The author applied general scientific and special methods of investigation, in particular: system, structural-functional and comparative methods.

\section{Wills: concept, types and legal regulation of testamentation and certification}

The concept of a will as a personal arrangement made by a natural person in case of his/her death is given in Article 1233 of the Civil Code of Ukraine.

Thus, a will is a personal arrangement made by a natural person in case of his/her death, which is executed in writing with indication of the place and time of its construction and is certified by a notary or specially authorized officials. Natural persons in full civil capacity have the right to make a will, and making a will through a representative is not permitted. That is, the testator implements the right to dispose of property in case of death.

The list of subjects who have the power to certify a will is established in part three of Article 1247 of the Civil Code. In particular, a will is certified by a notary or other officials specified in Articles 1251-1252 of this Code.

Having analyzed the norms of Articles 1251-1252 of the Civil Code of Ukraine, Articles 1, 37, 38, 40 of the Law of Ukraine "On Notariate", we came to the conclusion that Article 1247 of the Civil Code does not include to the circle of persons who have the right to certify wills - officials of consular institutions of Ukraine, and in cases stipulated by the current legislation, diplomatic missions.

Bodies of notariate and quasi-notariate have the right to make and certify wills. Bodies of notariate include public and private notaries, and bodies of quasi-notariate include officials of local governments, other officials authorized to carry out certain types of notarial acts in accordance with the current legislation [1, p. 797]. 


\section{Theoretical-legal and applied aspects of the notarial procedure concerning...}

The peculiarity of the will lies in the fact that it contains the wish of the person during his/her lifetime, but the direct implementation of this wish is possible under an indispensable condition - the death of this person. This circumstance causes special requirements to the form and content of the will, because after the death of the testator, nobody has the ability to specify or clarify his/her intentions [2, p. 73].

As O. Kalinichenko affirms, "form" and "kind" of the will are not the same categories. We consider the form of the will as a way of expression of will, which is the procedure of certification of a specified transaction by the authorized public individuals, official persons. The specified procedure is determined by the subject of certification of the will and certain order of committing such actions. A kind of the will describes the content of this transaction (a will with condition, a will with substitution of heir, a will with institution of executor, etc.) or subject composition (a personal will; a marital will), and it does not concern the procedure of certification. We support the opinion of the scientist that we can classify wills according to two criteria: depending on the subject of certification and the procedure of certification. Depending on the subject of certification, wills can be classified into the following groups: notarial and non-notarial that equal to notarial form [3, p. 112]. At the same time, it is advisable to consider "nonnotarial wills" as quasi-notarial because this concept is much wider than wills that equal to notarial.

Depending on the procedure of certification, wills are divided into three groups: an ordinary will; a will in the presence of witnesses; a secret will.

An ordinary will is certificated according to the rules of Article 1247 of the Civil Code of Ukraine. It is executed in writing with indication of the place and time of its construction. The testator has the right to include either the entire inheritance, or a part thereof in the will and to institute one or several natural persons or other participants of civil relations, the territorial community or the state as his/her heirs.

A will in the presence of witnesses is certificated in accordance with Article 1253 of the Civil Code of Ukraine.

The legislator establishes two types of certification of wills in the presence of witnesses. The first type - it takes place at the request of the testator, and the second - at the obligatory presence of witnesses. A will in the presence of witnesses is regulated by Articles 1248, 1252 of the Civil Code of Ukraine. 
A secret will is certificated only by public and private notaries. In accordance with Article 1249 of the Civil Code of Ukraine, a secret will is the will certified by the notary without reading its contents. The person who constructed the secret will should submit it in a closed envelope to the notary. The envelope must have the testator's signature. The notary makes a notarial record, attaches a seal on the envelope, and puts it in another envelope and seals in the testator's presence.

We agree with the opinion of $\mathrm{O}$. Kalinichenko that the main goal of the institution of the secret will is to protect the secrecy of the will [3, p. 112].

Ukrainian scientists S. Fursa and Ye. Fursa rightly draw the analogy between certification of a secret will and such a notarial act as acceptance of the document for storage, according to which the document can be taken by the notary without getting acquainted with its contents [4, p. 66].

In article 1243 of the Civil Code the legislator provides that a married couple may make a joint will with regard to the property jointly owned thereby.

We support the position of N. Shama, as a joint will is a variety of a will, and hence the unilateral transaction in which one side is represented by several persons, namely a married couple, then the possibility of making it is caused by the presence of two conditions simultaneously:

1) the marriage status of persons who wish to make a joint will; and

2) the presence of full legal capacity required for making a will in each of the spouses [5, p. 179].

In our opinion, the specificity of this will is that:

- to devise only the property jointly owned,

- the person that determined by agreement between the spouses should get the hereditary property,

- the spouse who survived continues to live in a normal property environment [6, p. 13].

It is worth to emphasize, that in case of death of one of the spouses, a share in joint ownership belonging to a deceased spouse passes to the survivor. The legislator established that the spouse who survived does not have the right to alienate the property that was the joint property of the spouses and the object of the joint will.

Heirs of the marital will are persons instituted in the will; however, they can take possession of the property only after the death of both spouses. 
In accordance with part three of Article 1243 of the Civil Code, in the lifetime of both spouses, either of them has the right to refuse from the joint will. The refusal from the joint will should be notarized. However, the application cannot cancel a joint marital will. In our opinion, in this case it is necessary to use a mutual cancellation of previously joint will made by both members of the couple. In practice, a marital will is not wide spread. In case of death of one of the spouses, the latter (who remained alive and is not a person of advanced age), mainly, changes his/her mind of the future heir. Therefore, most of notaries offer each of the spouses to make a separate will for a part of the property earned during the time of the registered marriage.

We agree with N. Vasylyna that after dissolution of marriage the former spouses do not lose the opportunity to leave the right to preserve their will for the property jointly owned [7, p. 111].

Certification of wills by notaries and authorized public individuals and official persons takes place in accordance with the current legislation, including the civil and notarial legislation.

In our opinion, the Ukrainian modern legislation on notariate is a set of normative and legal acts that are accepted by the authorized public bodies, in which there are rules regulating the organization and competence of notarial bodies of the state, procedural order of making notarial acts, as well as committing other actions, different from notarial, with the aim of providing them with a legal reliability [8, p. 363, 376].

The acts of other branches of law governing the separate questions of organization of notariate and exercise of notarial activities include, for example, the Civil Code of Ukraine, the Family Code of Ukraine, the Land Code of Ukraine, the Tax Code of Ukraine and others [8, p. 315].

Having made the analysis of notarial activities of independent Ukraine, we came to a conclusion "about the need for separation of its three parts, namely:

the legislation regulating the general principles for the creation and activities of notariate and quasi-notariate;

the legislation regulating the procedure of notarial acts;

the legislation regulating the commitment of other actions, different from notarial, with the aim of providing them with a legal reliability [8, p. 367].

While certificating wills notaries, public individuals, official persons, consular officials must comply with the Constitution of Ukraine, the Civil, Family, Land Code of Ukraine, the Law of Ukraine "On Notariate", the 
Consular Statute of Ukraine, the Procedure of certifying wills and powers of attorney that are equal to notarial, as well as other normative and legal acts.

It should be emphasized that the legislation has determined certain public individuals, official persons who have the right to do it in the process of certifying wills that are equal to notarial.

Analyzing the norms of Article 1252 of the Civil Code of Ukraine, as well as Article 40 of the Law of Ukraine "On Notariate", we define subjects of certifying wills and powers of attorney that are equal to notarial.

In accordance with Articles 1251-1252 of the Civil Code of Ukraine, Articles 1, 37, 38, 40 of the Law of Ukraine "On Notariate" the subjects who have the right to certify wills are:

- public and private notaries (Article 1248 of the Civil Code of Ukraine "Certification of Wills by Notary", Article 36 of the Law of Ukraine "On Notariate");

- authorized officials of the relevant local government (Article 1251 of the Civil Code of Ukraine "Certification of Wills by Local Government Officials", Article 37 of the Law of Ukraine "On Notariate");

- other public individuals and official persons (Article 1252 of the Civil Code of Ukraine "Certification of Wills by Other Officials", Article 40 of the Law of Ukraine "On Notariate"), namely:

1) a chief medical officer, or a deputy thereof, or a doctor on duty of the hospital, or other in-patient health care institution, or the director or chief medical officer of the old people's home or invalids' asylum;

2) a person on board a sea or river vessel under the flag of Ukraine;

3) a person participating in a search party or expedition;

4) the commander (head) of the unit, detachment, institution, military training institution;

5) a prison governor;

6) the head of the trial center.

- officials of the consular institutions of Ukraine, and in cases stipulated by law, diplomatic representatives (Article 38 of the Law of Ukraine "On Notariate").

Only public notaries who work at state notary's offices have the right to certify wills. State notaries of public notary archives are deprived of such rights. They issue only duplicates of wills that are in their possession.

In accordance with Article 9 of the Law of Ukraine "On Notariate" "Restrictions of notarial acts", a notary and an official of local self- 
government, who commit notarial acts, have no right to perform notarial acts in their name and on behalf of their name, in the name of and on behalf of their husband or their wife, his (her) and their relatives (parents, children, grandchildren, grandfather, grandmother, brothers, sisters), and also in the name of and on behalf of the employees of the notary's office, workers who are in labor relations with a notary public, or staff members of the executive committee. Officials of local government are also not entitled to perform notarial acts in the name of and on behalf of this executive committee. In these cases, notarial acts are committed at any other public notary's office, at the private notary or at the executive committee of another village, township, and city Council of people's deputies.

You should pay attention to the fact that in the norms the legislator has "forgotten" about notarial acts committed by authorized consular officials. Restrictions of notarial acts for specified persons are regulated by Article 49 of the Consular Statute of Ukraine, approved by the Decree of the President of Ukraine dated April 2, 1994, no. 127/94. The consul cannot perform notarial acts, including wills, in his name and on behalf of his name, in the name and on behalf of her (his) wife (husband), her (his) and their lineal relatives. That is, the consul can certify a will on behalf of the employees of the consulate, which is not valid as for us.

Public individuals, official persons listed in Article 40 of the Law of Ukraine "On Notariate" that certify the wills equal to notarial, are not entitled to certify wills in their name and on behalf of their name, as well as in the name of and on behalf of his wife or her husband. Specified public individuals, official persons have also no right to perform wills on behalf of their sons and daughters, mother, father, grandchildren, grandfather, grandmother, including their brothers or sisters.

The law states that in this case wills and power of attorney are not valid.

The legislator refers to the duties of a notary (in accordance with Article 5 of the Law of Ukraine "On Notariate") to keep confidential information obtained by him/her in connection with making notarial acts. Swearing the oath a person who first is engaged in notarial activities takes his oath to keep professional secrets.

The question of keeping the notary's secrecy has its historical experience. For example, the question of the secrecy of notarial acts was settled by Austrian Notarial Regulations dated July 25, 1871. In accordance with paragraph 37 of the Regulations, the duties of a notary public included not 
only his keeping the secrecy of notarial acts before the parties, but also supervising over the observance of secrecy by his assistants. In particular, the notary guaranteed that all information of the notarial act that took place in his presence, actually took place in his presence in that way; the notary was responsible for all inexactitudes, even if they had been committed due to an error. The indemnification did not abolish a penalty of dignity for nonperforming notary's duties.

At the time of independence of Ukraine, the question of keeping the secrecy of notarial acts has been attracting the attention of legislators. Article 8 of the Law of Ukraine "On Notariate" dated September 2, 1993 in the original edition was called "The observance of secrecy of committed notarial acts" and it did not contain the concept of notary's secrecy. The article has undergone numerous changes, additions and redactions of individual parts and as a whole. Only the Law of Ukraine "On amendments to the Law of Ukraine "On Notariate" dated October 1, 2008, no. 614-VI issued the new wording of Article 8 of the Law, which changed the title of the article and at the legislative level the definition of notarial secrecy was given. Notarial secrecy is the totality of the information obtained during committing the notarial act or addressing the interested party to a notary, including the information about property, personal property and nonproperty rights and obligations, etc.

Notarial secrecy needs to be treated with the two sides. On the one hand, it is the secrecy of a person addressing to making the notarial act (the motive and the fact of addressing to the notary; providing with documents; achieving the result after addressing to the notary; information about the private life of a person, etc.), on the other hand - it is the secrecy of the notary as a specialist (information about advice, consultations, etc.). These two characteristics of the concept of the secrecy of notarial acts are important. We support the opinion of S. Fursa and Ya. Panteliienko that both concepts of the secrecy of notarial acts must be legislatively fixed $[9$, p. 87].

Notarial secrecy must be kept by:

- notaries who work at state notary's offices, state notarial archives or are engaged in private practice as a notary;

- officials of the local authorities who are authorized to perform notarial acts;

- officials of consular institutions who commit notarial acts; 
- officials who in accordance with Articles 40 and 40-1 of the Law of Ukraine "On Notariate" commit notarial acts;

- persons who got to know about committing notarial acts in connection with performance of their official duties or work; persons involved in notarial acts as witnesses and other persons who got to know information that was the subject of notarial secrecy. Such persons also include: assistant, consultant, secretary, clerk of a notary, even if their activity is limited to providing legal assistance or familiarization with documents and the notarial act was not committed.

We agree with M. Diakovych that "actually the secrecy of notarial activities, including notarial acts, must ensure inviolability of private life of citizens who apply to a notary. Sometimes a notary is compared with the priest, to whom a person can confess and trust him with all his/her cherished sides of life, which should not be spread, because it is a seal of confession. Similarly, the notary is responsible for divulging of secrets of notarial acts. The person who trusts the notary with his/her secrets, respectively, should have certainty that all information discussed with the notary will never become the subject of public discussion" [10, p. 73].

Persons that are guilty of violating the notarial secrecy will bear responsibility in order established by law.

There is the reason in views of S. Leskiv and A. Chubenko that the secrecy of the will consists in the following: before opening of inheritance persons signing the will for the testator are deprived of the right to divulge secret information about 1 ) the fact of making the will; 2) the contents of the will; 3) the cancellation or modification of the will [11, p. 158].

In accordance with the judicial practice, during certification of the will the fact of violation of the secrecy of the will does not entail declaring it invalid, but only in the presence of other violations of law. This is also confirmed by the explanations of the Plenum of the Supreme Court indicated in paragraph 8 of resolution no. 2 (v0002700-92) dated January 31,1992 "On judicial practice in cases involving complaints about notarial acts or refusal of their committing" where a notarial act cannot be cancelled only for reasons of underexposed secrets of its committing because the legislation on notariate does not provide such consequences.

We agree with D. Zhuravlov, O. Korotiuk and K. Chyzhmar that the subject of the notarial secret is protected by law as information with restricted access, namely - secret information. The secret information 
includes information not only about the person who applied for taking notarial acts, but also information about the provided advice, etc. [12, p. 52].

Notaries', public individuals, official persons who certificated wills, can give information or papers about their certification to individuals who concluded those documents or to others by their power of attorney. If persons, on behalf of whom the documents had been concluded, died, then the information or papers are issued to their heirs. However, under the law, public individuals, official persons who certificated wills, can give papers about their certification within ten working days upon reasonable written request to the Court, the Prosecutor's Office, the bodies of the pre-trial investigation, operative units in connection with criminal proceedings, civil, economic, administrative cases, administrative offences that are under the proceedings of specified bodies, with the obligatory indication of the numbers (criminal proceedings) and affixing the stamp seal of the authorized body.

Although the principle of freedom of the will gives a wide scope of legal authorities for post-mortuary disposition to the testator, but at the same time it limits his/her right to deprive the rights of inheritance of the compulsory heirs [13, p. 10].

The testator has no right to deprive the rights to inheritance of those heirs who are legally entitled to a hereditary portion of the right to succession. According to Yu. Zaika, such persons should be called forced heirs [14, p. 136].

It should be noted that the right to hereditary portion of inheritance was existed in the Roman law, which was a quarter of a legal portion, i. e., the portion that the heir would have received in case of legal succession (compulsory portion).

According to Ye. Fursa, the right to hereditary portion - it is a redistribution of inheritance by the state taking into account the interests of the most vulnerable sections of citizens in case of no stating them in the will or violation of their rights within the contents of the will. This position is understandable, and this right of the state is no doubt today, because some people need extra protection of their interests. The author also hopes that in future our country will provide such persons with aid at its expense [15, p. 75].

Only persons determined in part 1 of Article 1241 of the Civil Code of Ukraine have the right to hereditary portion of inheritance. Such persons include: 
1) the testator's juvenile children, grown-up incapable children (including the adopted),

2) incapable widow (widower),

3) irrespective of the will, incapable parents inherit half of the shares that would belong to each of them in case of legal succession (compulsory portion).

The specified list is not subject to the extended interpretation, i.e. it is exhaustive.

In this case the right to hereditary portion of inheritance does not depend on the consent of the other heirs, the volition of the testator; and it is not connected with joint residence of the testator and persons who have the right to the compulsory portion. The right to hereditary portion of inheritance has personal nature and may not move in the order of hereditary transmission [16, p. 240].

Thus, a will is a unilateral transaction made by a natural person in case of his/her death, which is executed in writing with indication of the place and time of its construction, personally signed by the testator and certified by a notary or specially authorized officials.

\section{Features of the proceedings in the notarial procedure concerning the certification of wills}

Notarization of wills takes a special place among the notarial acts, especially in state notary's offices and in the bodies of local self-government.

The advantages of the notarial form of the transaction are that it provides a greater degree of legitimacy and credibility of its contents, clarity and certainty regarding the fact of committing the agreement. To make sure that the transaction complies with the law, the notary defines the essence of the respective relations, explains their legal qualifications, checks the capability of the natural person, as well as its actual will. In addition, the notary has appropriate education and work experience, which greatly reduces the possibility of declaring the will null and void in accordance with the court decision after opening of the inheritance [3, p. 110].

Before certification of the will, the notary, the authorized public individuals, official persons are obliged to explain the testator's rights:

- irrespective of any family relations, the testator may institute one or several natural persons or other participants of civil relations as his/her heirs; 
- in case of making the will in favor of several persons, the testator institutes the hereditary portion of his/her property to each of the heirs;

- the testator may leave all his/her property or a share of it, in particular, the usual household and private items, as well as leave the property which would become his/her property in future and which would be at the testator's disposal at the day of his/her death;

- without specifying the reasons, the testator may divest any of the legal heirs of the right to succession;

- the testator has the right to make testamentary renunciation in the will, or legate;

- the testator has the right to modify or cancel the will at any time and to make a new will. A later will cancels the previous will fully or in the part where it contradicts the latter;

- the testator has the right to appoint a testamentary executor (only by his/her consent), who acts as the guarantor of the implementation of the testator's will.

According to the Regulations on Hereditary Register, the notary, an official of local self-government, other public individuals, official persons must specify the date and place of birth of the testator in the text of the will.

Persons that cannot make a will are:

- adult persons recognized incapable in accordance with the court decision (for example, persons who are not capable to realize the significance of their actions and (or) control them due to chronic, stable psychological disorder);

- adult persons in limited civil capacity, in accordance with the court decision as a result of the abuse of alcohol, narcotic, toxic substances, etc. [6, p. 10].

First of all, the testator must be legally capable at the moment of making the will. The further loss of capacity by the testator after making the will is not the basis of declaring the will null and void. However, in the case of making the will by the incapable person, it (the will) will be always null and void.

Irrespective of any family relations, the testator may institute one or several natural persons or other participants of civil relations as his/her heirs. Without specifying the reasons, the testator may divest any of the legal heirs of the right to succession.

We agree with the opinion of M. Matsehora that while giving the right to certify the wills to public individuals, official persons - the legislator 


\section{Theoretical-legal and applied aspects of the notarial procedure concerning...}

follows the humane principle: to give a chance to express a will of the person [17, p. 148].

S. Sibilova states that the essence of the freedom of the will consists in the right of the testator to act freely, but it is necessary to point out two circumstances. The essence of the first circumstance is the testator, making the will, determines the fate of his/her property in case of death, i.e. carries out the powers that belong to him/her as the owner of the property. In accordance with part 1 of Article 319 of the Civil Code of Ukraine, the owner possesses, uses and disposes of his/her property at his/her own discretion. The essence of the second circumstance is the hereditary relationship is one of the kinds of civil relations. Not only the participants of hereditary relationships have the right to act freely, but the participants of all other civil relations have it too and it is based on the principle of autonomy of the will of each of them. Since unilateral transactions may be regulated not only by the general norms, but also the special norms that apply to certain unilateral transactions, Article 3 of the Civil Code of Ukraine should be provided with the warning that freedom of the unilateral transaction exists only in cases if other is not established by law governing a specific kind of the unilateral transaction [18, p. 135-140].

We consider it is necessary to pay a special attention to a notarial procedure of certification of wills in the presence of witnesses.

Only persons in full civil capacity may be witnesses. The following persons cannot be witnesses: notaries or other officials certifying the will; testamentary heirs; family members and close relatives of testamentary heirs; and persons incapable of reading and signing the will due to illness or physical disability.

O. Kukhariev made a properly confirmed conclusion that witnesses involved in the procedure of certification of wills should testify:

a) at the moment of testamentation and certification of the will, the testator understood the significance of his/her actions and could control them (this fact can be established only by witnesses visually);

b) the testator expressed his/her true will, and mental or physical influence was not applied to him/her;

c) the testator personally signed the will, or by the testator's request the will was signed by another person in his/her presence [19, p. 109].

Wills in the presence of witnesses should contain the witnesses' personal data: surname, name and patronymic name of the witness, the date of his/ 
her birth, the place of residence, and requisites of the passport or other document based on which the identity of the witness was established.

The witnesses in whose presence the will is certified should read it aloud and put their signatures thereon.

The witness is responsible for harm caused by him/her because of divulging of information, which became known in connection with his/her participation in committing the statutory notarial act.

We share the thought of S. Fursa about expediency of the creation of the State Register of Persons, limited in capacity and incapable, herewith notaries and other public individuals, official persons who use the specified information in their activities should have free access to the specified register [20, p. 320].

A similar mechanism is to greatly simplify the procedure of checking the capacity of natural persons, and therefore the certification of wills, reduce the number of refusal to commit the notarial acts [21, p. 64].

Natural persons in full civil capacity have the right to make a will. The will is constructed by one natural person (excepting the marital will). Making the will through a representative is not permitted. The will is executed in writing with indication of the place and time of its construction, the date and place of birth of the testator. The will must be personally signed by the testator.

The testator may write the will manually or using the common technical devices.

By the testator's request, public individuals, official persons may construct the will at the testator's dictation manually or using the common technical devices. In this case, the will shall be read aloud and signed by the testator.

If a testator cannot read or sign the will because of physical incapability, the will is certified in presence of two witnesses and another natural person can sign the will.

To certify the will, the testator is not required to submit documents confirming his/her right to hereditary property. Property may be testate only for ownership. The testator may impose on a heir inheriting a house, apartment or other movable or immovable property an obligation to convey the right to use the said pecuniary right or property (some part of it) to a third person. The right to use a house, apartment or other movable or immovable property shall remain valid in case of consequent change of the owner thereof. The text of the will is constructed so that the disposal 


\section{Theoretical-legal and applied aspects of the notarial procedure concerning...}

of the testator would not excite misunderstanding or doubts at the time of executing the inheritance.

The notary, authorized public individuals, official persons have the right to testify the will with condition. For the creation of the right to succession, the testator may envisage a certain condition for the person specified in the will either related or not related to this person's behavior (existence of other heirs, residence at a certain place, birth of a child, education, etc.) The condition established in the will should exist at the moment of opening of the inheritance. A condition established in the will shall be void if it contradicts law or moral principles of the society.

If there is a situation when the person-testator envisages the condition of observing the moral principles of the society, therefore it is necessary to apply to the provisions of the Law of Ukraine "On Protection of Public Morality", in which public morality is revealed as a set of rules of behavior and ethical standards based on the human ideas of kindness, honor, dignity, as well as on the cultural and spiritual values. We agree with N. Fomichova that the will with condition has already existed for a long time, but there is the problem of its legislative regulation now [22, p. 259].

The testator may oblige the heir to take certain actions of non-pecuniary nature, particularly with regard to disposal of personal documents and to take certain actions aimed at the achievement of socially beneficial goals etc.

During certification of the will the notary, authorized public individuals, official persons should explain the contents of Article 1241 of the Civil Code of Ukraine concerning the right to hereditary portion to the testator and the contents of Article 1307 of the Civil Code of Ukraine concerning the void will made by the alienator with regard to the property specified in the succession agreement.

In case of certification of the will on deposit, which is stored in the Bank (financial institution), the text of the will specifies the number of the account, the full name and location of the Bank (financial institution), which kept the deposit.

The will is constructed and certified in duplicate. It is not allowed the presence of the natural person in favor of whom the property is instituted; the natural person cannot be present during the signing of the will, as well as sign it instead of the testator.

The notary, authorized public individuals, official persons certifying the will cannot sign the will instead of the testator. 
The captain of the sea or river vessel under the flag of Ukraine should transmit one copy of the will certified by him to the chief of the Ukrainian port or the consul of Ukraine in a foreign port for transferring it to the state notarial archive at the permanent place of residence of the testator.

If the testator had no permanent place of residence in Ukraine or the place of his/her residence is unknown, the will is transmitted to the Kiev State Notarial Archive.

It is worth noting, the information that certified wills are liable entering in the Succession register was introduced by the order of the Ministry of Justice of Ukraine dated October 17, 2000, no. 51/5 "On Succession Register". According to the fifth provision of the order, all wills, constructed and certified, modified or cancelled per the procedure established by the law, started succession cases and issued certificates of inheritance from December 01, 2000 are subject to mandatory registration in the Succession register [23, p. 56].

As of 2018, wills are subject to mandatory state registration in the Succession register per the procedure established by Regulations on Succession register approved by the order of Ministry of Justice of Ukraine dated July 07, 2011 no.1810/5, registered in the Ministry of Justice of Ukraine on July 11, 2011no. 831/19569.

In particular, in accordance with paragraph 2.1.1. of the Regulations, the registrar enters the following information about the testator (testators, in case of certification of a joint will of a married couple) in the Succession register: surnames and names, patronymic names (if there are) of the testator (testators); the registration number of the discount card of the taxpayer in accordance with the State register of natural persons taxpayers or the reason of its absence; the place of residence or location; the date and place (if it is unknown-the name of the country) of birth. Therefore, the listed information should be necessarily mentioned in the text of the will.

Entering the information about wills in the Succession register, which are certified by the authorized public individuals, official persons, indicated in Article 1252 of the Civil Code of Ukraine and part 1 of Article 40 of the Law of Ukraine "On Notariate", is carried out by state notarial archives in case of accepting a copy of the will in storage.

It is appropriate to note that the secret wills are not widely spread in Ukraine. In particular, there is a problem with the announcement of the 
secret will. Notaries-practical workers offer to solve the problem in the following way. While bearing the testator's signature on the secret wills the notary offers to make a list of the persons whom the notary would invite during the announcement of the will.

Information about the presence of the constructed will, with the exception of the testator, is issued only after the death of the testator according to a submission of a certificate (notarized copy) of his/her death.

Analyzing the question of the certification of wills by a captain of the ship A. Nahorna draws attention to the fact that the captain has no legal education and has a little practice of certifying the wills, it can lead to issues unregulated by the legislator [24, p. 180].

Examining the wills certified by heads of a search party or expedition A. Nahorna offers "a simplified procedure of the certification of wills during expeditions" [25, p. 180].

When developing the idea of the certification of wills by bodies of quasinotariate it is necessary to emphasize that notarial acts in local governments are committed only by persons who can perform notarial acts based on the decision of the Executive Committee. Deciding the question of the authority for committing notarial acts and acts that equal to notarial, the body of local government takes into account the presence of legal education, practical skills for notarial acts, etc. As a rule, in the decisions you should provide for another person who will perform notarial acts in the absence of a primary worker (vacation, illness, business trip, etc.).

This practice should be applied to public individuals, official persons listed in Articles 40, 40-1 of the Law of Ukraine "On Notariate". Thus, it is necessary to make the appropriate changes to the Law of Ukraine "On Notariate" and the Civil Code of Ukraine.

We agree with the opinion of most researchers, including M. Matsehora, that the lack of legal qualification of public individuals, official persons entitled to certify causes insufficient explanation of the testator's rights and obligations, even breaking the form of the will [17, p. 148].

As public individuals, official persons certifying the wills that equal to notarial do not possess the necessary knowledge of current legislation regarding the certification of wills, in particular in the field of civil, family, land law, it causes insufficient explanation of the testator's rights and obligations, i.e. restricts the right of the latter to objective declaration of intention during construction of wills or powers of attorney. 


\section{Dolynska Mariia}

S. Leskiv and A. Chubenko prove that at present there is no effective mechanism for the protection of the testator's rights from different violations and therefore there is an objective need for amending current legislative acts [11, p. 159].

The procedure of declaring the will null and void is established in Article 1257 of the Civil Code of Ukraine.

According to S. Sibilova, the will can be neither void nor feigned $[26$, p. 210]. The legislator proves that only the court may declare a will null and void if it establishes that the testator's will was not free or did not conform to his/her intention.

Consequences of invalidity of a separate arrangement in the will and the will in general are provided by norms fixed, respectively, in parts 3 and 4 of Article 1257 of the Civil Code of Ukraine. These norms are special. There is a textual discrepancy between the general rule fixed in Article 217 of the Civil Code of Ukraine concerning legal consequences of invalidity of separate parts of transaction and rules fixed in Article 1257 of the Civil Code of Ukraine concerning invalidity of a separate arrangement in the will. In accordance with the general norm, invalidity of a separate part of a transaction shall not entail invalidity of its other parts or of the transaction as a whole, where it might be assumed that the transaction could have also been concluded without inclusion of the invalid part therein. In accordance with the special norm, declaring null and void of a separate arrangement in the will shall not entail declaring its other parts null and void without any assumptions [27, p. 279].

In our opinion, one of the most important reasons of declaring the will null and void is certification of the will that equal to notarial by public individuals and official persons without the presence of two witnesses.

Declaring the will null and void or declaring it invalid in accordance with the court decision is one of the types of protection of hereditary rights and interests. There are a number of discursive and unsolved issues of financial and procedural nature that complicate the implementation of the hereditary rights and interests of heirs. The most common grounds for declaring the will null and void are the presence of a defect of will (desire), which is checked by conducting the death forensic psychiatric examination. The grounds for declaring the will invalid are not limited only by Article 1287 of the Civil Code of Ukraine, but other norms of the civil legislation concerning the invalidity of the transaction are also subject to the application. In order to provide hereditary rights and interests by the notary and to avoid errors 


\section{Theoretical-legal and applied aspects of the notarial procedure concerning...}

during construction of the will, which can lead to the possibility of recourse to the court for the purpose of declaring the will invalid, we agree with the authoritative opinion of Ukrainian scientists A. Chubenko and S. Leskiv to exclude Article 1245 of the Civil Code of Ukraine concerning the secret will [28, p. 167].

\section{Conclusions}

The following theoretical conclusions were formulated:

1. Legal regulation of the proceedings in the notarial procedure in Ukraine, in particular the certification of wills, is carried out by a large number of normative and legal acts.

2. Certification of wills that are equal to notarial is conducted by notaries, public individuals, official persons in accordance with the current legislation of Ukraine.

3. We suggest the following definition of the will. A will is a unilateral transaction, which is executed in writing with indication of the place and time of its construction, the information about the testator: the surname and name, patronymic name (if there is); the registration number of the discount card of the taxpayer in accordance with the State register of natural persons - taxpayers or the reason of its absence; the place of residence or location; the date and place (if it is unknown-the name of the country) of birth, personally signed by the testator and certified by a notary or specially authorized officials.

4. We suggest supplementing the third part of Article 1247 of the Civil Code with the following sentence: "Certification of wills abroad is carried out by the consular institutions of Ukraine, and in cases stipulated by the current legislation, by diplomatic missions of Ukraine".

5 . There is the same procedure of testamentation and certification of wills by notaries and officials of local self-government as well as by authorized public individuals and official persons. However, public individuals and official persons have the right to certify the wills that equal to notarial only with the participation of at least two witnesses.

6. The lack of legal education (not necessarily higher legal education) and practical experience in drafting legal documents of public individuals and official persons entitled to make wills that equal to notarial in practice leads to breaking the form of the will and declaring it invalid in accordance with the court decision. Therefore, we recommend public individuals and official 
persons to constantly work on improving their legal level, in particular in the field of civil, family, and land law. Authorized territorial bodies of the Ministry of Justice of Ukraine should provide public individuals and official persons with methodical recommendations on certification of wills that equal to notarial with appropriate samples of the documents.

7. In the current legislation we propose to establish the procedure for the substitution of the public individuals and official persons authorized to certify wills that equal to notarial.

The prospects for further research are the more detailed analysis of the notarial and judicial practice concerning the certification of wills.

\section{References:}

1. Dolynsjka M.S. (2015) Stanovlennja ta rozvytok pravovogho reghuljuvannja notarialjnoji dijaljnosti $v$ Ukrajini [Formation and development of legal regulation of notarial activity in Ukraine]. Ljviv: LjvDUYS. (in Ukrainian)

2. Zajika Ju.O. (2004) Forma zapovitu jak umova jogho dijsnosti [Form of will as a condition of its validity]. Visnyk Khmeljnycjkogho instytutu reghionaljnogho upravlnnja ta prava, no. 1-2, pp. 73-76.

3. Kalinichenko O. (2004) Formy zapovitu za Cyviljnym kodeksom Ukrajiny [Forms of the will according to the Civil Code of Ukraine]. Visnyk Kyjivsjkogho nacionaljnogho universytetu imeni Tarasa Shevchenka. Jurydychni nauky, vol. 88, pp. 110-112.

4. Fursa S. Ja., Fursa Je. I., Klymenko O. M. (2007) Spadkove pravo: Notariat. Advokatura. Sud: Nauk.-prakt. posib. [Hereditary right: Notary. Advocacy. Court: Sciences. Pract. manual]. Kyjiv: Vydavecj Fursa S. Ja. : KNT. (in Ukrainian)

5. Shama N. (2013) Pravo na spiljnyj zapovit [The right to a common will]. Proceedings of the Problemy derzhavotvorennja i zakhystu prav ljudyny $v$ Ukrajini (Ukrain, Ljviv, ljutyj 7-8, 2013) (eds. Bojko A.M., Semkiv V.O., Rabinovych P.M., Kossak V.M., Nor V.T., Pylypenko P.D., Ghuralj P.F., Tyshhyk B.J.), Ljviv: Jurydychnyj fakuljtet Ljvivsjkogho nacionaljnogho universytetu imeni Ivana Franka, pp. 179-181.

6. Dolynsjka M.S. (2007) Spadkuvannja v Ukrajini [Inheritance in Ukraine]. Dovidnyk notariusa. vol. 5, $96 \mathrm{pp}$.

7. Vasylyna N. V. (2014) Pravo na zapovit ta okremi pytannja jogho realizaciji [The right to testament and features of its realization]. Naukovyj visnyk Uzhghorodsjkogho nacionaljnogho universytetu, vol. 28, pp. 107-111.

8. Dolynsjka M.S. (2017) Stanovlennja ta rozvytok zakonodavstva pro notarialjnu dijaljnistj $v$ Ukrajini [Formation and development of the notarial activities legislation in Ukraine] (PhD Thesis), Ljviv: Ljvivsjkyj nacionaljnyj universytet imeni Ivana Franka.

9. Fursa S. Ja. (ed) (2012) Teorija notarialjnogho procesu: Naukovo-praktychnyj posibnyk [Theory of the notarial process: Scientific and practical manual]. Kyjiv: Alerta. (in Ukrainian) 


\section{Theoretical-legal and applied aspects of the notarial procedure concerning...}

10. Djakovych M.M. (2018) KHrestomatija notarialjnogho prava Ukrajiny: Navch.posibn. [Textbook of the Notary Law of Ukraine: Teach. manual]. Kyjiv: Istyna. (in Ukrainian)

11. Lesjkiv S. R. Chubenko t A. Gh. (2014) Svoboda zapovitu i tajemnycja zapovitu jak jurydychni gharantiji realizaciji prava na spadkuvannja za zapovitom [Freedom of the will and mystery of will as a legal guarantees of right to inheritange by will [Naukovyj visnyk Uzhghorodsjkogho nacionaljnogho universytetu]. Serija pravo, vol. 29, pp. 156-159.

12. Zhuravljov D. V., Korotjuk O.V., Chyzhmarj K. I. (2017) Pravova okhorona notarialjnoji tajemnyci: monoghrafija [Legal protection of notarial secrets]. Kyjiv: OVK. (in Ukrainian)

13. Zajika Ju.O., Rjabokonj Je. O. (2009) Spadkove pravo: Navch.posibn. [Hereditary right: teach. manual]. Kyjiv: Jurinkom Inter. (in Ukrainian)

14. Zajika Ju.O., Spivak V.M. (2000) Pravo vlasnosti. Spadkove pravo: Navchaljyj posibnyk [Ownership. Hereditary right: teach. manual]. Kyjiv: Naukova dumka. (in Ukrainian)

15. Fursa S. Ja., Fursa Je. I. (2002) Spadkove pravo: Teorija ta praktyka: Navchaljyj posibnyk [Inheritance right Theory and practice: a manual ]. Kyjiv: Atika. (in Ukrainian)

16. Dolynsjka M.S. (2012) Osoblyvosti vydachi notariusamy svidoctv pro pravo na spadshhynu za zapovitom [Features notaries issuing certificates of inheritance by will ]. Visnyk Ljvivsjkogho universytetu. Serija jurydychna, vol. 56, pp. 237-243.

17. Maceghora M. V. (2007) Forma zapovitu: stanovlennja, rozvytok, suchasni vymoghy [Form of the will: becoming, development and modern requirements]. Forum prava [Forum law] (electronic journal), no. 2, pp. 146-150. Available at: http://nbuv.gov.ua/UJRN/FP_index.htm_2007_2_24, (accessed 05 december 2017).

18.Sibiljova S. (2012) Svoboda zapovitu za chynnym cyviljnym zakonodavstvom Ukrajiny [Freedom of the will under current civil law of Ukraine ].Visnyk akademiji pravovykh nauk Ukrajiny, no. 2, pp. 131-140.

19. Kukharjev O. Je. (2011) Spadkove pravo Ukrajiny: Navch. - prakt. posib. [Hereditary Law of Ukraine: Teach. - practice manual]. Kyjiv: Alerta ; CUL. (in Ukrainian).

20. Fursa S. Ja. (2002) Notarialjnyj proces: Teoretychni osnovy [Notarial process: Theoretical basis]. Kyjiv: Istyna. (in Ukrainian)

21. Kalinichenko O. (2013) Shhodo posvidchennja zapovitiv nachaljnykom slidchogho izoljatora [As to the certificate of wills, the head of the investigatory detention center]. Bjuletenj Ministerstva justyciji Ukrajiny, no. 6, pp. 60-66.

22. Fomichova N. V. (2016) Skladannja zapovitu z umovoju ta dijsnistj vyznachenykh umov u mezhakh jikh vykonannja za zakonodavstvom Ukrajiny [Composing a will with a provision and actuality of particular provisions within the limits of their realization according to the legislation of Ukraine], Molodyj vchenyj, no. 9 (36), pp. 257-260.

23. Dolinskaya M. S. (2014) Nekotorye aspekty notarial'nogo udostovereniya zaveshchaniy i oformleniya nasledstva na ikh osnovanii v Ukraine [Some aspects 
of the notarization of wills and inheritance registration on the basis of their in Ukraine], Notarial'nyy vestnik, no. 10, pp. 54-62.

24. Naghorna Gh. O. (2009) Realizacija prava na zapovit osoby, jaka perebuvaje pid chas plavannja na sudni [Realization of the right to the will of the person which is during navigation on a vessel]. Forum prava [Forum law] (electronic journal), no. 2, pp. 284-288. Available at: http://nbuv.gov.ua/UJRN/FP index. htm_2009_2_44 (accessed 05 december 2017)).

25. Naghorna A. O. (2010) Posvidchennja zapovitiv nachaljnykamy poshukovykh abo inshykh ekspedycij [Certificate of wills by chiefs of search or other expeditions]. Visnyk Kharkivsjkogho nacionaljnogho universytetu vnutrishnikh sprav, no. 2, pp. 251-255.

26. Sibiljova S. (2012) Umovy dijsnosti zapovitiv za chynnym cyviljnym zakonodavstvom Ukrajiny [Conditions for the validity of the will under the civil legislation law of Ukraine]. Universytetsjki naukovi zapysky, no.3, pp. 202-211.

27. Sibiljova S. (2013) Ponjattja, vydy j naslidky nedijsnykh zapovitiv za chynnym cyviljnym zakonodavstvom Ukrajiny [Conceptiog, types and consequences of invalid wills as to the current civil legislation of Ukraine]. Problemy zakonnosti, vol. 123, pp. 271-281.

28. Chubenko A. Gh., Lesjkiv S. R. (2014) Nikchemnistj zapovitu ta vyznannja zapovitu nedijsnym: cyviljno-pravovi aspekty [Insignificance of will and invalidation of will: civil and legal aspects]. Molodyj vchenyj, no.11(14), pp. 165-168. 
The church as an institution of civil society: the experience of becoming...

THE CHURCH AS AN INSTITUTION OF CIVIL SOCIETY:

THE EXPERIENCE OF BECOMING IN MODERN UKRAINE

\section{ЦЕРКВА ЯК ІНСТИТУТ ГРОМАДЯНСЬКОГО СУСПІЛЬСТВА: ДОСВІД СТАНОВЛЕННЯ В СУЧАСНІЙ УКРАЇНІ}

\section{Dudka Larisa ${ }^{1}$}

DOI: http://dx.doi.org/10.30525/978-9934-571-29-9_5

Abstract. Institutions, among which special place belongs to the church, play important role in development of civil society in modern Ukraine. This article analyzes the causes, capabilities, features and characteristics of the process of church formation as full and effective institution of civil society in Ukraine during independence period. Since the conditions and possibilities for the realization of such tasks by religious institutions depend on state policy in the religious-church sphere, it requires a detailed analysis of the main measures of the state on the development and implementation of legislative initiatives aimed at ensuring freedom of conscience, the activity of churches and religious organizations in Ukraine during the period of independence. The overcoming of ideological barriers, former class-antagonistic methodological approaches, access to new sources of information nowadays allows us to truly research religious processes in Ukraine. The study of state-church relations in Ukraine during the period of independence was carried out on the basis of an analysis of the legal and regulatory framework that provides the legal framework for regulating these relations, taking into account the current achievements of scientists in this regard. Also, data from sociological surveys of public opinion about the level of trust of the Ukrainian population to church institutions are used. Religious and church processes raise the interest of different categories of the Ukrainian population as scientists and representatives of state structures, which must provide effective forms and methods for their implementation. In author's opinion, the status and level of citizens' rights for freedom of

\footnotetext{
${ }^{1}$ Candidate of Historical Sciences, Docent of Political Science and Law Department, History and Law Faculty, Nizhyn Gogol State University, Ukraine

(C) Dudka Larisa
} 
conscience, the nature of church-state relations and the use of the considerable potential of the church as a social institution largely depends on the position of the government, the presence of a clear and understandable policy for religion and religious organizations, preparedness for constructive dialogue with the religious community and mutual respect. Despite some positive trends, this study made it possible to characterize the state policy in this area as inconsistent and unpredictable. Despite a number of positive moments evidencing the movement of state-church relations to the understanding and establishment of a partnership model of relations between the state and church institutions, this sphere is not currently excluded from both state-church and inter-confessional problems and conflict situations. At the same time Ukraine historical experience and current practices assure that adequate state-church relations are necessary for a democratic state of law, which is obliged to ensure the public's right for freedom of conscience and for the development of civil society, as churches and religious organizations, being involved in social life, are both public institutions.

\section{1. Вступ}

Складні й суперечливі процеси в економіці, політиці та національній свідомості відбуваються в Україні вже тривалий час. Важливою передумовою успішного подолання кризових явищ, досягнення економічного та культурного процвітання, зміцнення співпраці та порозуміння між державою і широким громадським загалом є становлення громадянського суспільства. Нам украй потрібна демократична консолідація європейського гатунку, яка має на меті формування толерантності, поваги до прав людини, вміння долати стереотипи і знаходити компроміси.

Серед численних факторів суспільного життя, які відбиваються на політиці й суспільстві в цілому, є релігія. Упродовж багатьох століть, а особливо сьогодні, релігійні доктрини та релігійні інститути безпосередньо й опосередковано впливали й впливають на суспільно-політичні процеси будь-якої країни. Україна не є виключенням, а враховуючи специфіку сучасної церковно-релігійної ситуації та складнощі у забезпеченні політичної стабільності та суспільної злагоди між усіма іiі громадянами цей процес у нашій країні має свої особливості та неоднозначні наслідки. 


\section{The church as an institution of civil society: the experience of becoming...}

Попри значну кількість наукових досліджень, присвячених проблемі взаємин релігії й суспільства, держави та церков і релігійних організацій, ця тема продовжує нині залишатися дискусійною. Подолання ідеологічних бар'єрів, колишніх упереджених методологічних підходів, доступ до раніше заборонених джерел інформації нині дають змогу справді на науковому рівні досліджувати релігійні процеси в Україні. Релігійно-церковні процеси викликають підвищений інтерес різних категорій населення України. Науковців цікавлять їх історичні та теоретичні аспекти, а представників державних структур - переважно практичні питання, пов'язані 3 пошуком ефективних форм i методів управління ними. Актуальність дослідження взаємодії держави й церкви підтверджується як світовим досвідом, так і сучасними внутрішньодержавними подіями, які переконливо свідчать, що в ескалації політичних та міжетнічних конфліктів нерідко виступає релігійний чинник $[12,26]$.

Питання державно-церковних відносин, реалізація принципу свободи совісті в Україні періоду незалежності, взаємовплив релігійних інституцій і держави проаналізовано в роботах В. Бондаренка, А. Колодного, В. Любчика, П. Панченко, В. Рибалка, М. Бабія, В. Сленського, Л. Филипович та ін. У працях політологічного, соціологічного та історичного спрямування знайшли своє відображення процеси становлення громадянського суспільства в Україні. Проте вплив церкви на його формування та їі місце в цьому процесі висвітлено поки що недостатньо повно. Водночас, варто констатувати, що ця сфера сучасного суспільного життя $є$ багато в чому неоднозначна і потребує додаткових досліджень та узагальнень.

Дана наукова стаття має своїм завданням розглянути характерні риси сучасних українських практик у сфері взаємовідносин між державою та церквою як соціальним інститутом задоволення релігійних потреб людей, а також розкрити особливості процесу становлення церкви як дієвого та повноправного інституту громадянського суспільства в Україні. Оскільки умови та можливості реалізації релігійними інституціями таких завдань залежать від державної політики в релігійно-церковній сфері, це вимагає детального аналізу основних заходів держави на шляху розробки та впровадження законодавчих ініціатив щодо забезпечення свободи совісті, діяльності церков та релігійних організацій в Україні періоду незалежності. 


\section{Dudka Larisa}

\section{2. Церква як соціальний інститут}

Належні державно-церковні відносини є необхідними не лише для побудови демократичної правової держави, зобов'язаної забезпечити реалізацію права громадян на свободу совісті, але й для становлення громадянського суспільства, оскільки церкви та релігійні організації виконують не лише притаманні їм функції, але й, будучи суспільними інститутами, є причетними до соціального життя, освіти, культури, благодійної діяльності тощо.

Цілком зрозумілим є те, що релігійні об'єднання не можуть існувати поза суспільством, вони не можуть бути нейтральними відносно того, що відбувається у суспільстві. Витиснуті з політичного життя за радянських часів релігійно-церковні організації вийшли на авансцену політичного життя. До основних причин, що привели до зростання рівня релігійності населення та відчутної активізації діяльності церковних конфесій, релігійних організацій у соціально-політичному, державно-політичному та соціально-культурному житті країни варто віднести: процеси лібералізації та демократизації суспільно-політичної життя в умовах перебудовчих реформ другої половини 1980-х років; вакуум у масовій свідомості, що виник після краху тоталітарної ідеології; глибоко вкорінені релігійно-культурні традиції, особливо в західноукраїнських областях, які продовжували існувати, незважаючи на перманентний тиск державно-партійних структур впродовж всього радянського минулого; активна презентативна діяльність церков та релігійних організації в напрямку поглиблення державно-конфесійного співробітництва та апробації привабливих суспільно значимих соціальних проектів та програм.

Відновлення Україною державного суверенітету започаткувало нову віху в історії соціального служіння діючих на іiі теренах конфесій. Церкви та релігійні організації отримали можливість стати не уявними, не декларованими, а реальними дієвими суб'єктами суспільного життя.

Як зазначено в проекті Концепції державно-конфесійних відносин в Україні, відокремлення церкви від держави жодним чином не означає відокремлення церкви від суспільства, заборону іiі участі в суспільному житті. Навпаки, в документі наголошується на тому, що сепараційний принцип взаємин держави і релігійних організацій звільняє церкви й деномінації від одержавлення, тотального контролю 
над їхнім внутрішнім життям, внутрішніми приписами та релігійною практикою, закладаючи підгрунтя для розвитку партнерських взаємин між державою та релігійними інституціями [21, с. 59].

Слід підкреслити, що церква як соціальний інститут, володіючи певним досвідом суспільної діяльності та високим рівнем довіри до неї громадян нашої держави порівняно з іншими суспільними інституціями має значний потенціал і досвід позитивного впливу на українське суспільство, зокрема на процес побудови громадянського суспільства. На підтвердження даної думки слугують дані соціологічного опитування громадської думки «Омнібус» щодо рівня довіри населення соціальним інститутам, що було здійснено в грудні 2016 року Київським міжнародним інститутом соціології. За результатами опитування найбільшою довірою серед українців користуються церква, волонтери та Збройні Сили України. Порівняно з 2015 роком рівень довіри до церкви майже не змінився, вона продовжує утримувати позиції лідера довіри українців - це 56,7 \% населення нашої країни [6]. Не викликає сумніву, що саме активність релігійних організацій на ниві соціального служіння обумовлює високий рейтинг довіри до них у суспільстві, а також закладає підгрунтя для формування партнерської моделі державно-конфесійних відносин.

Суспільно корисна діяльність конфесій характеризується багатовекторністю, наявністю суспільно значимих проектів, пошуком нових форм ведення роботи. Ряд релігійних організацій насамперед докладають зусиль до розв'язання проблем соціально незахищених верств населення: облаштовують пункти безкоштовного харчування нужденних; забезпечують медичне забезпечення та лікування малозабезпечених; допомагають школам, будинкам-інтернатам, медичним закладам; створюють при храмах і монастирях дитячі будинки, школи-сиротинці, соціально-реабілітаційні центри для нарко- та алкоголезалежних осіб, хворих на СНІД; займаються духовною опікою громадян, які перебувають у виправних закладах тощо [25].

Значну увагу церкви та релігійні організації приділяють роботі 3 молоддю, організовують літній відпочинок дітей з бідних сімей, дітей-сиріт та дітей-інвалідів. Практично в кожній релігійній організації діють спеціальні структурні підрозділи, що опікуються проблемами дітей, підлітків та юнацтва. Активно долучаються церкви до процесу формування громадянської культури населення, здійс- 


\section{Dudka Larisa}

нення благодійницької діяльності, розгортання волонтерського руху, налагодження міжнародних зв'язків, що дозволяє реалізувати значну кількість спільних соціальних ініціатив, здійснення наукової і просвітницької роботи тощо.

Незважаючи на різнобічність і масштабність суспільної активності церков та конфесій, є підстави вважати, що соціальний потенціал останніх використовується не на повну потужність. Серед основних причин такого стану варто виділити живучість радянських ідеологем у масовій свідомості та наслідки багаторічної практики побудови безрелігійного суспільства, відносно повільна адаптація релігійних конфесій до нових суспільних реалій, конфліктність та політизація міжконфесійних та міжцерковних взаємин [25].

Задля подолання цих труднощів та для більш повного використання церквою свого досвіду та потенціалу у реалізації функцій соціального служіння їй потрібна допомога держави у забезпеченні необхідними умовами та ресурсами. Це повинно проявитися перш за все через створення нормативно-правової бази та формування дієвого механізму співпраці, що забезпечили б відповідні умови для діяльності церкви як дієвого та повноправного інституту громадянського суспільства.

Виконуючи такі функції, церква зможе розв'язувати важливі для всього соціуму проблеми, привертати до них увагу держави, коли треба - змушувати iї корегувати свою політику в потрібному для суспільства напрямі. Вона буде здатна забезпечувати зворотний зв'язок між державою і суспільством, пропонуватиме свої програми вирішення суспільних питань та активно долучатиметься до їх практичної реалізації [4, с. 108].

\section{3. Державно-церковні відносини: досягнення на шляху до порозуміння}

Беззаперечним $є$ твердження, що стан та рівень забезпечення права громадян на свободу совісті, а також характер державно-конфесійних відносин значною мірою залежать від позиції державної влади, наявності у неї чіткої та зрозумілої політики стосовно релігії та релігійних організацій, готовності до діалогу з релігійною спільнотою і пошуку консенсусу з нею.

Згідно сучасної української моделі державно-церковних відносин, держава і церква визначаються як рівноправні суб'єкти державно-цер- 
ковних відносин, кожен з яких діє у сфері своєї компетенції, взаємно підтримуючи один одного. При цьому релігійні організації діють у правовому полі держави, держава не втручається в справи церкви, забезпечуючи свободу релігії, свободу церкві, сприятливі умови іії діяльності. Отже, конституційне закріплення принципу відокремлення церкви від держави не відкидає як їхньої взаємної відповідальності, так і можливості співпраці у сфері соціального захисту, охорони здоров'я, культури, науки, мистецтва тощо. Завдячуючи таким підходам, процес релігійного відродження у незалежній Україні набув незворотнього характеру і виявився у зростанні релігійності населення, чисельності релігійних організацій, розширенні спектру конфесійного розмаїття $[19$, с. 7$]$.

Із прийняттям незалежності України спостерігаємо суттєві зміни, що відбуваються як у церковно-релігійній сфері, так і в докорінній перебудові державно-церковних відносин. Зокрема, сформувалося національне законодавство щодо забезпечення свободи совісті та діяльності релігійних організацій. Базовий Закон «Про свободу совісті і релігійні організації» від 23 квітня 1991 року [12] з наступними змінами та доповненнями, а також більшість законодавчих актів, що регулювали окремі питання, за експертними оцінками загалом на належному рівні забезпечували як реалізацію права громадян на свободу совісті, так і розвиток церковно-релігійної мережі.

Відповідно до ст. 7 Закону України «Про свободу совісті та релігійні організації» головною ланкою релігійно-церковного життя в Україні $\epsilon$ релігійна організація. Релігійними організаціями в Україні є релігійні громади, управління і центри, монастирі, релігійні братства, місіонерські товариства, духовні навчальні заклади, а також об'єднання, що складаються 3 вищеозначених релігійних організацій. Метою утворення релігійної організації є задоволення релігійних потреб віруючих громадян. Це означає, що віруючі повинні не тільки мати можливість колективно сповідувати свою релігію в богослужінні, виконанні релігійних ритуальних обрядів, а й реалізовувати за допомогою цих організацій приписи своєї релігії у повсякденному житті, вільно та цивілізовано їх пропагувати і поширювати [12].

Такий підхід до утворення релігійних організацій відповідає вимогам міжнародного права, зокрема підсумкового документа Віденської зустрічі представників держав-учасниць наради за безпеку і співробіт- 


\section{Dudka Larisa}

ництво в Свропі (1989р.), яким визначені принципи утворення релігійних організацій та їх правовий статус. Головною складовою частиною його стало право віруючих колективно сповідувати свою релігію і організовуватися для цього у свої традиційні церковні (ієрархічні та інституційні) структури.

У 1990-х роках можемо виокремити знакові події, що свідчили про намагання налагодити постійний дієвий міжконфесійний діалог. Зокрема, з цією метою у грудні 1996 р. за сприяння Державного комітету України в справах релігії була створена Всеукраїнська рада Церков і релігійних організацій (далі - ВРЦіРО) як представницький міжконфесійний консультативно-дорадчий орган [1].

Мета ВРЦіРО - об’єднання зусиль Церков і релігійних організацій 3 духовного відродження України, координації міжцерковного діалогу як в Україні, так і за іiї межами, участі в розробці проектів нормативних актів 3 питань державно-конфесійних відносин, здійснення комплексних заходів добродійного характеру. Рада функціонує на засадах рівності та рівноправ'я, поваги до внутрішніх настанов і традицій усіх діючих в рамках Конституції України релігійних організацій і $€$ незалежною від органів державної влади України, політичних партій, інших громадських формувань та їх керівних органів. Станом на листопад 2016 року до складу ВРЦіРО входять 16 церков і релігійних організацій та 1 міжцерковна організація, серед яких православні, греко- і римсько-католицькі, протестантські та євангельські церкви, а також іудейське та мусульманське релігійні об'єднання. Відтак Рада Церков представляє більше ніж 90 \% усіх релігійних організацій України.

На сьогодні Всеукраїнська Рада Церков і релігійних організацій є найбільшою і найавторитетнішою громадською інституцією в Україні. Рада Церков бере активну участь у громадському житті країни, реагуючи на суспільні виклики публічними заявами, миротворчими та іншими заходами. Особливу увагу Рада Церков звертає на необхідність утвердження в суспільстві справедливості, забезпечення свободи віросповідання та інших фундаментальних прав людини, захисту суспільної моралі, боротьби з корупцією, належного соціального захисту вразливих і малозабезпечених верств населення, проведення чесних і прозорих виборів.

Окрім Всеукраїнської Ради Церков і релігійних організацій на національному рівні функціонують і інші консультативно-дорадчі органи, такі як Нарада представників християнських церков України, Рада 
Євангельських Протестантських Церков України, Всеукраїнська Рада Християнських Церков, Раду представників Духовних управлінь і центрів мусульман України які також займають досить активну позицію в сфері державно-церковних відносин. Однак Всеукраїнська Рада Церков і релігійних організацій у порівнянні з іншими аналогічними інституціями більш послідовно і системно працює в напрямку законодавчого забезпечення свободи совісті та віросповідання в Україні [9].

Усталеного характеру набула практика зустрічей глав і представників Церков і релігійних організацій та перших осіб держави, насамперед - Президента України та прем'єр-міністра, що відкривало перспективи до порозумінь та конструктивного діалогу між державою та церковними інституціями.

Загалом, за експертними оцінками Центру Разумкова, розвиток подій у церковно-релігійній сфері, за всіх проблем, свідчив про рух державно-конфесійних відносин на паритетних, партнерських засадах [21].

\section{4. Розмови без діалогу: труднощі та виклики державно-церковних відносин}

Після реорганізації системи органів державної влади в незалежній Україні функції щодо забезпечення проведення державної політики щодо релігії та діяльності релігійних організацій покладалися на державний орган виконавчої служби, який часто змінював свій статус та підпорядкування. Так, з 1991 р. до сьогодні функції державного органу у справах релігій виконували: Рада у справах релігій при Кабінеті Міністрів України, Міністерство України у справах національностей, міграцій та культів, Державний комітет України у справах релігій, Державний департамент у справах релігій Міністерства юстиції України, Державний комітет України у справах національностей та релігій.

Проте, Указом Президента України «Про оптимізацію системи центральних органів виконавчої влади» від 09 грудня 2010 р. було ліквідовано Державний комітет України у справах національностей та релігій, функції з реалізації державної політики у сфері релігії покладено на Міністерство культури України, у структурі якого було створено Департамент у справах релігій та національностей [25].

При цьому варто зазначити, що ще в 2008 р. при Кабінеті Міністрів України була створена Комісія з питань забезпечення реалізації прав релігійних організацій. Останнього разу засідання комісії проводилось 


\section{Dudka Larisa}

у жовтні 2012 р., а перед цим ще три роки засідання не скликалися. 4 березня 2015 року була затверджена Постанова Кабміну України про відновлення та активізацію роботи комісії, основними завданнями якої є сприяння координації дій органів виконавчої влади 3 питань забезпечення реалізації прав релігійних організацій та підготовка пропозицій щодо формування і реалізації державної політики у сфері державно-конфесійних відносин. Проте, як зазначає Інститут релігійної свободи жодного засідання так і не було скликано. I це при тому, що за словами релігійних діячів та експертів, міжвідомчого опрацювання потребують питання спрощення реєстрації релігійних організацій та перереєстрації їх статутів, функціонування капеланської служби в умовах російської агресії та порядок проходження альтернативної служби під час мобілізації, вирішення питань гуманітарної допомоги та багато інших.

Проте, після президентських виборів у лютому 2010 р. ситуація змінюється. Зокрема, знаковими для 2010 р. можна виділити наступні факти:

1) незважаючи на задекларовані принципи рівного ставлення до всіх Церков і релігійних організацій країни (ч. 5 ст. 5 Закону України «Про свободу совісті і релігійні організації» [11]), не було проведено жодної зустрічі Президента ні з ВРЦіРО, ні з представниками окремих Церков і релігійних організацій, за винятком Української ПЦ (МП) та Російської ПЦ, що, на жаль, не свідчить про рівноправність усіх релігійних організацій, оскільки тодішній глава держави відкрито демонстрував свою прихильність УПЦ (МП) не як приватна особа, а як Президент України, представляючи позицію держави;

2) як уже було зазначено вище, Комісія при Кабінеті Міністрів жодного разу не збиралася;

3) у грудні 2010 р. без будь-яких консультацій з релігійною спільнотою Указом Президента ліквідовано Державний комітет України у справах національностей та релігій (його функції передані: в частині реалізації державної політики у сфері релігії - до Міністерства культури; в частині реєстрації релігійних організацій - до Державної служби реєстрації України) [26]. Крім того, у стінах Верховної Ради України було порушено питання про ліквідацію Національної експертної комісії України з питань захисту суспільної моралі (законопроект № 6532), з якою тісно співпрацює ВРЦіРО. 


\section{The church as an institution of civil society: the experience of becoming...}

Ну і нарешті, варто наголосити на значній активізації присутності та діяльності в Україні Патріарха Московського і всієї Русі Кирила - це мало виразний політичний характер, що визнавали навіть представники РПЦ [3]. Безпрецедентним фактом є участь громадянина Російської Федерації, патріарха Російської ПЦ Кирила в інавгурації Президента України В.Ф. Януковича 25 лютого 2010 року. У цій ситуації був порушений Указ Президента України «Про державний протокол і церемоніал» від 22 серпня 2002 року № 746/2002, за яким благословення новообраного президента мало б відбутися у Софії Київській главами різних церков та релігійних організацій [22, с. 60]. Виглядає так, що втративши політичний контроль над країнами колишнього СРСР, сьогоднішне московське політичне та церковне керівництво бере під свою опіку так звану «канонічну територію» Московського Патріархату [14, с. 136].

Значного негативного резонансу не лише в релігійному середовищі, але й у суспільстві загалом, набули спроби прийняття нової редакції базового Закону про свободу совісті без узгодження із Всеукраїнською радою церков і релігійних організацій.

Питання розробки нової редакції зазначеного Закону або внесення змін до нього постало у зв'язку з рекомендаціями Парламентської Асамблеї Ради Свропи від 5 жовтня 2005 р. Відзначивши прогресивний характер названого Закону, ПАРС рекомендувала його вдосконалення 3 урахуванням сучасних реалій суспільного життя [7]. Увесь цей час ВРЦіРО, громадські організації виступали за те, що змінам базового закону (як і інших законів, що стосуються забезпечення права реалізації свободи совісті) має передувати прийняття Концепції державно-церковних відносин, яка має бути покладена в основу зазначених змін, а головне - розроблена та прийнята за участі та згоди релігійної спільноти. Головною метою такої Концепції, як справедливо зазначає Ю. Решетніков, має бути формування й законодавче закріплення такої ефективної моделі державно-конфесійних відносин в Україні, яка б 3 урахуванням як духовно-релігійних традицій українського народу, так і досвіду демократичних країн світу найбільшою мірою відповідала б сучасним реаліям релігійно-церковного життя та заклала перспективи його подальшого розвитку [23, с. 22].

Однак, вже 16 березня 2012 р. на розгляд Верховної Ради було подано законопроект, що передбачав внесення змін до 36 чинних зако- 


\section{Dudka Larisa}

нодавчих актів, у тому числі й до Закону «Про свободу совісті та релігійні організації». Зміни до базового Закону у сфері свободи совісті стосувались ускладнення реєстрації релігійних організацій, посилення контролю над діяльністю релігійних організацій, ускладнення контактів українських релігійних організацій з представниками зарубіжних релігійних організацій, проповідниками, місіонерами та ін. [10].

Зазначений законопроект викликав гостру критику як у релігійному, так і в експертному середовищі. Однак, 16 жовтня 2012 р. Верховна Рада приймає законопроект у другому читанні без будь-якого обговорення поправок з боку профільного комітету. Слід відзначити, що глави конфесій оперативно відреагували на ухвалення вказаних змін до Закону «Про свободу совісті та релігійні організації» і вже наступного дня звернулися до В. Януковича 3 «рішучим закликом накласти вето на цей закон» у частині внесення змін до базового закону у сфері свободи віросповідання. У свою чергу Президент на зустрічі з ВРЦіРО 17 жовтня відповів, що «думка Ради церков матиме велике значення при прийнятті рішення про долю цього закону» [21, с. 56-57]. Однак, попри позицію представників релігійного та експертного середовища, оприлюднення Відкритих листів громадських організацій, правозахисників і науковців із вимогою ветування законопроекту та повернення його на доопрацювання, 21 листопада він був підписаний Президентом.

Окреслена ситуація продемонструвала відкрите ігнорування Президентом України та більшістю депутатського корпусу позицій релігійної спільноти. Більш того, можна зазначити, що не лише зміни до базового Закону про свободу совісті, але й процес їх прийняття стали образою почуттів релігійних організацій та їх лідерів, віруючих і просто демократично налаштованих громадян України. Настоятель Української Греко-Католицької Церкви Святослав (Шевчук) в інтерв'ю газеті «День» зазначив, що ця подія змусила Глав Церков говорити про кризу в державно-церковних відносинах [2].

Церковно-релігійне життя в Україні ускладнюється не лише перманентними кризами в державно-церковних відносинах, але й суттєвими міжконфесійними конфліктами. 3 прийняттям незалежності настав новий період історії православної церкви, яка поступово стає на шлях відновлення, самостійності, втраченої ще в 1686 р., оновлюється у своїй соборності. Однак, ще маємо тягар старих і нових міжцерковних проблем, в епіцентрі яких - міжправославний конфлікт, який про- 
довжує залишатися напруженим. Протистояння на релігійному грунті, що охопило не лише церковних діячів, служителів культу, мільйони віруючих, а й політиків, позначається на різних сферах життя українського суспільства, зокрема $є$ причиною зростання соціальної напруги та поглиблення суспільних протиріч. Важко не погодитись з В. Сленським, який наголошує, що без ліквідації міжцерковного конфлікту Україна не зможе досягти громадянської злагоди та гарантованої суспільної стабільності [8, с. 38-39].

3 іншого боку, не варто однозначно відкидати досить поширену сьогодні думку, що консолідувати український народ на релігійному підгрунті практично неможливо. Більше того, намагання згуртувати його в такий спосіб призводить до подальших розколів та конфесійного розшарування. У зв'язку з цим необхідно вкрай обережно ставитися до безумовно привабливої ідеї проголошення єдиної помісної православної церкви. Тим більше, світовий історичний досвід переконливо демонструє, що досягнення суспільної згуртованості принципово неможливе на шляху самовизначення та формування ідентичності політичної, національної чи конфесійної. Цей процес надто складний і потребує, щонайперше, толерантності, взаємної поваги і суспільної злагоди всіх наявних в Україні церков, а постановку питання про українську національну церкву слід розуміти як добрий намір формування міжконфесійної єдності, яка сприяла б процесові консолідації українського народу.

За цих умов вважаємо, що вирішальну роль у залагодженні конфлікту мають відіграти лідери конфліктуючих сторін. Дуже часто саме від них залежить як перший, так і вирішальний крок до миру та злагоди.

\section{5. Громадські ради як елемент сучасного механізму державно-церковних відносин}

Для поглиблення як державно-конфесійного так і міжконфесійного діалогу, опрацювання конкретних механізмів співпраці між державою і церквою в різних сферах важливою є співпраця Церков і релігійних організацій у форматі консультативно-дорадчих органів при міністерствах та відомствах - громадських рад.

Сьогодні доволі активно свою роботу проводить Громадська рада при Міністерстві освіти і науки України з питань співпращуі з Всеу- 


\section{Dudka Larisa}

краӥнською радою Церков та релігійних організацій. У центрі уваги Громадської ради - питання сприяння запровадженню викладання предметів духовно-морального спрямування, опрацювання державного стандарту з богослов'я та інше. Результатом послідовних і багаторічних зусиль Громадської ради стало ухвалення 2 липня 2015 р. Президентом України Закону України «Про внесення змін до деяких законів України щодо заснування релігійними організаціями навчальних закладів», надавши таким чином релігійним організаціям право виступати суб'єктами заснування загальноосвітніх навчальних закладів різного рівня. Як зазначає Ю. Решетников, зазначений Закон носить без сумніву революційний характер у контексті подолання наслідків тоталітарної радянської політики щодо релігії та церкви та розбудови державно-конфесійних відносин на принципово нових демократичних засадах. Говорячи про надання релігійним організаціям вказаного права важливим $€$ не лише урівнення їх у цьому відношенні з іншими суб'єктами права і подолання їх штучної дискримінації, але і введення їх у число суб' єктів - учасників навчально-виховного процесу [24].

29 квітня 2009 р. відбулося установче засідання Ради у справах душпастирської опіки при Міністерстві оборони Украӥни, яка була утворена $з$ метою налагодження тісної співпраці Міністерства $з$ українськими Церквами і релігійними організаціями для задоволення релігійних потреб військовослужбовців та духовного, морально-естетичного, військово-патріотичного виховання особового складу Збройних Сил України [18]. Варто зазначити, що цій події роком раніше передувало підписання 10 листопада 2008 року Меморандуму про співпрацю у справах душпастирської опіки військовослужбовців Збройних Сил України [16]. Підписали документ, з одного боку, Міністерство оборони України, а з іншого - представники семи релігійних інституцій. Оборонне відомство країни у такий спосіб планувало здійснити практичні заходи, спрямовані на поетапне впровадження у Збройних Силах України ефективної системи душпастирської опіки та створення інституту військового духовенства (капеланства). Водночас необхідно зазначити, що законодавством України на той час це питання ще не було врегульовано і тому подібні дії були незаконними.

Проте, результатом роботи Ради у справах душпастирської опіки при оборонному відомстві стало розроблення Концепції душпастирської опіки у Збройних Силах України, яка була затверджена наказом 
Міністром оборони України 22 квітня 2011 р. [15]. Враховуючи зовнішню агресію Російської Федерації та необхідність захисту територіальної цілісності України, великим досягненням на шляху законодавчого унормування даного питання стало підписання 27 січня 2015 р. Положення про службу військового духовенства (капеланства) у Збройних Силах України [20].

Стратегічні рішення про формалізацію партнерства 3 профільними органами державної влади у вирішенні актуальних суспільних проблем ухвалили члени ВРЦіРО на своєму засіданні 16 грудня 2008 року. Це - підписання двосторонньої Угоди про співпрацю між Міністерством охорони здоров'я України та ВРЦіРО. Документ визначив ініціативи МОЗ щодо взаємодії з релігійними конфесіями у сферах захисту життя (звуження практики абортів), морально-етичної просвітницької діяльності серед медичних працівників, студентів медичних навчальних закладів та молоді, протидії епідеміям ВІЛ/СНІД та туберкульозу в Україні, запровадження медичного капеланства у вигляді хоспісів тощо [25].

Подальша співпраця мала наслідком утворення 4 червня 2009 року при Міністерстві охорони здоров'я України Громадської ради з питань співпраці з Всеукраїнською Радою Церков і релігійних організацій [17]. На робочих засідання представники конфесій та медичної спільноти розглядають питання пропаганди здорового способу життя, шляхи вдосконалення процесу вакцинації в Україні, обговорили проект «Етичного кодексу лікаря» тощо. Особливі зусилля докладають церкви і деномінації на ниві боротьби з ВІЛ/СНІДом. Координацію їхньої діяльності фактично здійснює Всеукраїнська рада Церков і релігійних організацій. Саме ВРЦіРО виступила засновником міжконфесійного діалогу у сфері подолання епідемії ВІЛ/СНІДу в Україні шляхом прийняття та впровадження «Концепції участі Церков та релігійних організацій України у протидії епідемії ВІЛ/СНІДу» і «Стратегії участі Церков та релігійних організацій України у протидії епідемії ВІЛ/СНІДу», що є унікальним досвідом.

Підставою для створення та діяльності Громадських рад при різних міністерства та відомствах $є$ положення нормативно-правових актів України, спрямованих на створення сприятливих умов для всебічної реалізації громадянами конституційного права на участь в управлінні державними справами, забезпечення відкритості діяльності органів 


\section{Dudka Larisa}

виконавчої влади, утвердження в Україні народовладдя і громадянського суспільства [5, с. 4-7].

Будь-яка співпраця може бути успішною лише за умови порозуміння сторін, що можливо забезпечити шляхом застосування діалогових форм управління. Роль та значення громадських рад як консультативно-дорадчих органів при органах влади переоцінити вкрай важко. Адже, через них як через форпости громадськості релігійні організації та віруючі мають можливість оперативно і конструктивно вирішувати нагальні питання церковно-релігійного життя. Важливо, що діяльність зазначених Громадських рад призводить до цілком конкретних управлінських рішень у сфері компетенції відповідних міністерств і відомств.

\section{6. Висновки}

Громадянське суспільство - це суспільство, якому властиве самоврядування вільних індивідів та добровільно створених ними організацій. Громадянське суспільство, як сферу самоврядування вільних індивідів, захищають від свавілля державної влади та жорсткої регламентації $з$ боку іiї органів відповідні закони. Ось чому в реальному суспільному житті громадянське суспільство та правова держава $є$ взаємозв'язаними інституціями, функціонування яких забезпечується верховенством закону, що надійно гарантує та захищає права і свободи громадян.

Незважаючи на дію цілком цивілізаційного принципу відділення церкви від держави, релігійні інституції аж ніяк не можуть існувати поза суспільством. Практика засвідчує, що церкви та релігійні організації не є байдужими до сучасних викликів та труднощів, що пронизуються життя українського населення, вони активно долучаються до суспільно корисної праці та реалізації свої соціальної місії. Проте, для більш повного та ефективного використання церквою свого досвіду та потенціалу у реалізації функцій соціального служіння в інтересах всього суспільства їй потрібна допомога та підтримка держави. Це повинно проявитися перш за все через створення нормативно-правової бази та формування дієвого механізму співпраці, що забезпечили б відповідні умови для діяльності церкви як дієвого та повноправного інституту громадянського суспільства.

Безумовно, ключову роль у становленні громадянського суспільства відіграє держава, точніше ті можливості, які вона може запро- 
понувати для інститутів громадянського суспільства. Ці можливості повинні грунтуватись на утвердженні толерантності, як важливій правовій і політичній потребі. Під толерантністю ми розуміємо повагу, сприйняття та розуміння різноманіття культур та форм самовираження й самовиявлення людської особистості. До того часу, доки в нашому суспільстві не виникне релігійна толерантність, ми не зможемо говорити про релігійні організації як повноправні інститути громадянського суспільства.

Аналіз процесу становлення моделі державно-церковних відносин в Україні періоду незалежності дає підстави охарактеризувати державну політику у цій сфері як непослідовну та непередбачувану. Незважаючи на ряд позитивних моментів, що засвідчує рух державно-церковних відносин до порозуміння та утвердження в цілому партнерської моделі взаємин між державою та церковними інституціями, ця сфера наразі не позбавлена як державно-церковних, так і міжконфесійних проблем та конфліктних ситуацій.

Відтак, залишається лише сподіватися, що досвід у налагодженні державно-церковних відносин минулих років буде детально проаналізовано й зазначені питання знайдуть своє законодавче розв'язання завдяки законотворчій роботі нової влади, що буде корисним не лише релігійній спільноті, а й усьому українському суспільству, значну частину якого становлять віруючі громадяни.

Розв'язання цих масштабних завдань потребує спільних зусиль державних інституцій різного рівня, представників релігійної спільноти, науковців, громадськості. А насамперед потребує переконаності у важливості поставленої мети і реальних зусиль щодо ії досягнення.

\section{Список літератури:}

1. 20 років на шляху діалогу та порозуміння [Електронний ресурс] // Режим доступу: http://vrciro.org.ua/ua/council

2. Блаженніший Святослав Шевчук. $€$ розмова, а діалогу немає... (Фрагмент інтерв’ю газеті «День», 11 січня 2013 р.) [Електронний ресурс] // Режим доступу: http://www.day.kiev.ua/uk/arhiv/no3-2013.

3. Васильев М. Янукович выбрал благословенне Патриарха Кирилла. KM.RU-Украина, 24 февраля 2010 г. [Електронний ресурс] // Режим доступу: www.km.ru/news/yanukovich_vybra_blagoslovenie.

4. Грінер О.М. Становлення Церкви як інституту громадянського суспільства: управлінський аспект/ О.М. Грінер // Релігія і церква в сучасних українських реаліях / Зб. матеріалів науково-практичної конференції «Релігія і 


\section{Dudka Larisa}

церква в сучасній Україні: стан, проблеми, перспективи» (м. Київ, 12 вересня 2007 p.). - К., 2007. - C. 107-116.

5. Громадські Ради: створення та організація роботи. Довідковометодичний посібник для членів громадських рад / За заг. ред. А.С. Крупника. Одеса: Одеський суспільний інститут соціальних технологій, 2012. - С. 4-7.

6. Довіра соціальним інституціям: прес-реліз Київського міжнародного інституту соціології [Електронний ресурс] // Режим доступу: http://kiis.com.ua/ ?lang $=$ ukr\&cat $=$ reports $\&$ id $=678 \&$ page $=1$

7. Доповідь Парламентської Асамблеї Ради Європи щодо виконання Україною обов'язків та зобов'язань від 5 жовтня 2005 р. [Електронний pecypc] // Режим доступу: www.minjust.gov.ua/0/6782.

8. Сленський В. Релігійне життя в Україні: стан, проблеми, шляхи оптимізації / В. Єленський. - К: Інститут філософії ім. Г. С. Сковороди НАНУ, 1996. - C. 38-39.

9. Заєць О. Всеукраїнська Рада Церков та релігійних організацій та її позиція відносно законодавчих ініціатив у релігійній сфері / О. Заєць [Електронний pecypc] // Режим доступу: http://www.irs.in.ua/index.php?option=com_content\& view $=$ article $\&$ id $=179 \% 3 \mathrm{~A} 1 \&$ catid $=37 \% 3$ Aart $\&$ Itemid $=64 \&$ lang $=u k$

10. Закон України «Про внесення змін до деяких законодавчих актів України щодо діяльності Міністерства юстиції України, Міністерства культури України, інших центральних органів виконавчої влади, діяльність яких спрямовується та координується через відповідних міністрів, а також Державного космічного агентства України» (реєстр № 1022) [Електронний pecypc] // Режим доступу: http://zakon4.rada.gov.ua/laws/show/5461-VI.

11. Закон України «Про свободу совісті і релігійні організації» від 23 квітня 1991 року № 987-XII [Електронний ресурс] // Режим доступу: http://zakon2.rada.gov.ua/laws/show/987-12

12. Здіорук С. І. Етноконфесійна ситуація в Україні та міжцерковні конфлікти / С. І. Здіорук. - К. : НІСД, 2007. - 160 с.

13. Здіорук С., Токман В. Соціальна діяльність церков та релігійних організацій в Україні: Аналітична записка [Електронний ресурс] // Режим доступу: http://old.niss.gov.ua/monitor/february2009/9.htm

14. Конфесіологія релігії : Колективна монографія // Українське релігієзнавство / За наук. ред. А. Колодного та Л. Филиповича. - 2-е доопрац. вид. Київ, 2009. - 237 с.

15. Концепції душпастирської опіки у Збройних Силах України [Електронний ресурc] // Режим доступу: http://www.irs.in.ua/index.php? option=com_content\&view $=$ article\&id $=861 \% 3 \mathrm{~A} 1 \&$ lang $=\mathrm{uk}$

16. Меморандум про співпрацю у справах душпастирської опіки військовослужбовців Збройних Сил України [Електронний ресурс] // Режим доступу: // https://risu.org.ua/ua/index/resourses/goverments_doc/military/42756/

17. Положення про Громадську раду при Міністерстві охорони здоров'я України [Електронний ресурс] // Режим доступу: http://www.moz.gov.ua/ua/ portal/polog_grRADA.html

18. Положення про Раду у справах душпастирської опіки при Міністерстві оборони України [Електронний ресурс]//Режим доступу: http://www.mil.gov.ua/ 


\section{The church as an institution of civil society: the experience of becoming...}

diyalnist/zvyazki-z-gromadskistyu/rada-u-spravah-dushpastirskoi-opiki-priministerstvi-oboroni-ukraini/rada

19. Попов Г. Особливості розвитку державно-церковних відносин та релігійно-церковного комплексу в сучасній Україні / Г. Попов // Релігія і церква в сучасних українських реаліях / Зб. матеріалів науково-практичної конференції «Релігія і церква в сучасній Україні: стан, проблеми, перспективи» (м. Київ, 12 вересня 2007 р.). - К., 2007. - С. 6-11.

20. Про затвердження Положення про службу військового духовенства (капеланську службу) у Збройних Силах України [Електронний ресурс] // Режим доступу: http://zakon5.rada.gov.ua/laws/show/z0161-15

21. Релігія і влада в Україні: проблеми взаємовідносин: Інформаційні матеріали до Круглого столу на тему «Державно-конфесійні відносини в Україні станом на 2013 рік: рух до партнерства держави і Церкви чи до кризи взаємин? (22 квітня 2013 р.) / Центр Разумкова за підтримки Фонду Конрада Аденауера в Україні. - К., 2013. -76 с.

22. Релігія і влада в Україні: проблеми взаємовідносин: Інформаційноаналітичні матеріали до Круглого столу на тему «Державно-конфесійні відносини в Україні, їх особливості і тенденції розвитку» (8 лютого 2011 р.) / Центр Разумкова за підтримки Фонду Конрада Аденауера в Україні. - К., 2011. $-82 \mathrm{c}$.

23. Решетніков Ю. Аналіз законодавчих ініціатив у сфері свободи совісті та державно-конфесійних відносин Верховної Ради України VI скликання / Ю. Решетніков // Релігія і влада в Україні: проблеми взаємовідноси: Інформаційні матеріали до Круглого столу на тему «Державно-конфесійні відносини в Україні станом на 2013 рік: рух до партнерства держави і Церкви чи до кризи взаємин? (22 квітня 2013 р.) / Центр Разумкова за підтримки Фонду Конрада Аденауера в Україні. - К., 2013. - С. 16-22.

24. Решетніков Ю. Громадська рада 3 питань співпраці з Церквами та релігійними організаціями при Міністерстві освіти і науки України як механізм забезпечення взаємодії держави та релігійних інституцій у сфері освіти / Ю. Решетніков [Електронний ресурс] // Режим доступу: http://www.edu-ugcc.org.ua/resursy/internet-resursy/

25. Указ Президента України «Про оптимізацію системи центральних органів виконавчої влади» № 1085 від 9 грудня 2010 р. [Електронний ресурс] // Режим доступу: http://president.gov.ua/documents/12584.html.

26. Шуба О. Релігія в етнонаціональному розвитку України (політологічний аналіз) / О. Шуба. - К: Криниця, 1999. - 309 с.

\section{References:}

1. Vseukrajinsjka Rada Cerkov i relighijnykh orghanizacij (2014) 20 rokiv na shljakhu dialoghu ta porozuminnja [20 years on the path to dialogue and understanding]. Retrieved from: http://vrciro.org.ua/ua/council (accessed 13 March 2018).

2. Shevchuk S. (2013) Je rozmova, a dialoghu nemaje... [There is a conversation, but there is no dialogue]. Retrieved from: http://www.day.kiev.ua/uk/arhiv/ no3-2013. (accessed 13 January 2016). 


\section{Dudka Larisa}

3. Vasylj'ev M. (2010) Janukovych vybral blaghoslovenne Patryarkha Kyrylla [Yanukovych chose the blessing of Patriarch Kirill]. Retrieved from www.km.ru/ news/yanukovich_vybra_blagoslovenie. (accessed 10 March 2018).

4. Ghriner O.M. (2007) Stanovlennja Cerkvy jak instytutu ghromadjansjkogho suspiljstva: upravlinsjkyj aspekt [The formation of the Church as an institution of civil society: the managerial aspect]. Proceedings of the Relighija i cerkva v suchasnij Ukrajini: stan, problemy, perspektyvy (Ukraine, Kyiv, September 12, 2007), Kyiv, pp. 107-116.

5. Krupnyk A. S. (ed.) (2012) Ghromadsjki Rady: stvorennja ta orghanizacija roboty [Public Councils: Creation and organization of work]. Odeca: Odesjkyj suspiljnyj instytut socialjnykh tekhnologhij. (in Ukrainian)

6. Kyjivsjkyj mizhnarodnyj instytut sociologhiji (2017) Dovira socialjnym instytucijam [Trust in social institutions]. Retrieved from: http://kiis.com. ua/?lang=ukr\&cat=reports\&id=678\&page $=1$ (accessed 14 March 2018).

7. Dopovidj Parlamentsjkoji Asambleji Rady Jevropy shhodo vykonannja Ukrajinoju obov'jazkiv ta zobov'jazanj (2005) [Report of the Parliamentary Assembly of the Council of Europe on Ukraine's obligations and commitments]. Retrieved from: www.minjust.gov.ua/0/6782. (accessed 10 July 2017).

8. Jelensjkyj V. (1996) Relighijne zhyttja v Ukrajini: stan, problemy, shljakhy optymizaciji [Religious life in Ukraine: state, problems, ways of optimization]. Kyiv: Instytut filosofiji im. Gh. S. Skovorody NANU. (in Ukrainian)

9. Zajecj O. (2008) Vseukrajinsjka Rada Cerkov ta relighijnykh orghanizacij ta jiji pozycija vidnosno zakonodavchykh iniciatyv u relighijnij sferi [AllUkrainian Council of Churches and Religious Organizations and its Position Regarding Religious Legislative Initiatives]. Retrieved from: http://www. irs.in.ua/index.php?option $=$ com_content $\&$ view $=$ article $\&$ id $=179 \% 3 \mathrm{~A} 1 \&$ catid $=37 \% 3$ Aart\&Itemid=64\&lang $=$ uk. (accessed 14 July 2017).

10. Zakon Ukrajiny "Pro vnesennja zmin do dejakykh zakonodavchykh aktiv Ukrajiny shhodo dijaljnosti Ministerstva justyciji Ukrajiny, Ministerstva kuljtury Ukrajiny, inshykh centraljnykh orghaniv vykonavchoji vlady, dijaljnistj jakykh sprjamovujetjsja ta koordynujetjsja cherez vidpovidnykh ministriv, a takozh Derzhavnogho kosmichnogho aghentstva Ukrajiny" [The Law of Ukraine "On amendments to some legislative acts of Ukraine..."]. Retrieved from: http://zakon4.rada.gov.ua/laws/show/5461-VI. (accessed 14 March 2018).

11. Zakon Ukrajiny "Pro svobodu sovisti i relighijni orghanizaciji" (1991) [The Law of Ukraine "On Freedom of Conscience and Religious Organizations"]. Retrieved from: http://zakon2.rada.gov.ua/laws/show/987-12. (accessed 14 March 2018).

12. Zdioruk S. I. (2007) Etnokonfesijna sytuacija v Ukrajini ta mizhcerkovni konflikty [Ethnic and religious situation in Ukraine and interchurch conflicts]. Kyiv: NICD (in Ukrainian)

13. Zdioruk S., Tokman V. (2009) Socialjna dijaljnistj cerkov ta relighijnykh orghanizacij v Ukrajini [Social activities of churches and religious organizations in Ukraine]. Retrieved from: http://old.niss.gov.ua/monitor/february2009/9.htm. (accessed 14 March 2018).

14. Kolodnyj A., Fylypovych L. (2009) Konfesiologhija relighiji [Confessionology of Religion]. Kyiv: Instytut filosofiji im. Gh. S. Skovorody NANU. (in Ukrainian) 


\section{The church as an institution of civil society: the experience of becoming...}

15. Koncepciji dushpastyrsjkoji opiky u Zbrojnykh Sylakh Ukrajiny [Concept of Pastoral Care in the Armed Forces of Ukraine]. Retrieved from: http://www.irs.in.ua/ index.php?option $=$ com_content\&view $=$ article\&id=861\%3A1\&lang=uk. $\quad$ (accessed 12 July 2017).

16. Memorandum pro spivpracju u spravakh dushpastyrsjkoji opiky vijsjkovosluzhbovciv Zbrojnykh Syl Ukrajiny (2008) [Memorandum on cooperation in pastoral care of servicemen of the Armed Forces of Ukraine]. Retrieved from: https://risu.org.ua/ua/index/resourses/goverments_doc/military/42756/. (accessed 14 March 2018).

17. Polozhennja pro Ghromadsjku radu pry Ministerstvi okhorony zdorov'ja Ukrajiny (2009) [Regulations on the Public Council under the Ministry of Health of Ukraine]. Retrieved from: http:// http://www.moz.gov.ua/ua/portal/polog_grRADA. html. (accessed 14 March 2018).

18. Polozhennja pro Radu u spravakh dushpastyrsjkoji opiky pry Ministerstvi oborony Ukrajiny (2009) [Regulations on the Council for Pastoral Care at the Ministry of Defense of Ukraine]. Retrieved from: http:// http:/www.mil.gov.ua/ diyalnist/zvyazki-z-gromadskistyu/rada-u-spravah-dushpastirskoi-opiki-pri-ministerstvi-oboroni-ukraini/rada. (accessed 13 March 2018).

19. Popov Gh. (2007) Osoblyvosti rozvytku derzhavno-cerkovnykh vidnosyn ta relighijno-cerkovnogho kompleksu v suchasnij Ukrajini [Features of development of state-church relations and religious-church complex in modern Ukraine].[The formation of the Church as an institution of civil society: the managerial aspect]. Proceedings of the Relighija i cerkva v suchasnij Ukrajini: stan, problemy, perspektyvy (Ukraine, Kyiv, September 12, 2007), Kyiv, pp. 6-11.

20. Pro zatverdzhennja Polozhennja pro sluzhbu vijsjkovogho dukhovenstva (kapelansjku sluzhbu) u Zbrojnykh Sylakh Ukrajiny (2015) [On Approval of the Regulations on the Service of the Military Clergy (Chaplaincy) in the Armed Forces of Ukraine]. Retrieved from: http://zakon5.rada.gov.ua/laws/show/z0161-15. (accessed 14 March 2018).

21. Centr Razumkova za pidtrymky Fondu Konrada Adenauera v Ukrajini (2013) Relighija $i$ vlada v Ukrajini: problemy vzajemovidnosyn [Religion and power in Ukraine: problems of mutual relations]. Proceedings of the Derzhavnokonfesijni vidnosyny v Ukrajini stanom na 2013 rik: rukh do partnerstva derzhavy i Cerkvy chy do kryzy vzajemyn? (Ukraine, Kyiv, April 22, 2013), Kyiv: Centr Razumkova za pidtrymky Fondu Konrada Adenauera v Ukrajini, p. 56.

22. Centr Razumkova za pidtrymky Fondu Konrada Adenauera v Ukrajini (2011) Relighija $i$ vlada v Ukrajini: problemy vzajemovidnosyn [Religion and power in Ukraine: problems of mutual relations]. Proceedings of the Derzhavnokonfesijni vidnosyny v Ukrajini, jikh osoblyvosti i tendenciji rozvytku (Ukraine, Kyiv, Fabruary 82, 2011), Kyiv: Centr Razumkova za pidtrymky Fondu Konrada Adenauera v Ukrajini, p. 8.

23. Reshetnikov Ju. (2013) Analiz zakonodavchykh iniciatyv u sferi svobody sovisti ta derzhavno-konfesijnykh vidnosyn Verkhovnoji Rady Ukrajiny VI sklykan$n j a$ [Analysis of legislative initiatives in the area of freedom of conscience and state-confessional relations of the Verkhovna Rada of Ukraine of the 5th convocation]. Proceedings of the Derzhavno-konfesijni vidnosyny v Ukrajini stanom na 


\section{Dudka Larisa}

2013 rik: rukh do partnerstva derzhavy i Cerkvy chy do kryzy vzajemyn? (Ukraine, Kyiv, April 22, 2013), Kyiv: Centr Razumkova za pidtrymky Fondu Konrada Adenauera v Ukrajini, p. 16-22.

24. Reshetnikov Ju. (2015) Ghromadsjka rada z pytanj spivpraci z Cerkvamy ta relighijnymy orghanizacijamy pry Ministerstvi osvity i nauky Ukrajiny jak mekhanizm zabezpechennja vzajemodiji derzhavy ta relighijnykh instytucij u sferi osvity [Public Council on Cooperation with Churches and Religious Organizations under the Ministry of Education and Science of Ukraine as a mechanism for ensuring interaction between the state and religious institutions in the field of education]. Retrieved from: http:// www.edu-ugcc.org.ua/resursy/internet-resursy/. (accessed 10 March 2018).

25. Ukaz Prezydenta Ukrajiny (2010) Pro optymizaciju systemy centraljnykh orghaniv vykonavchoji vlady [On optimization of the system of central executive authorities]. Retrieved from: http://president.gov.ua/documents/12584.html. (accessed 5 September 2017).

26. Shuba O. (1999) Relighija v etnonacionaljnomu rozvytku Ukrajiny (politologhichnyj analiz) [Religion in ethnonational development of Ukraine (political analysis)]. Kyiv: Krynycja. (in Ukrainian) 
LEGAL REGIME FOR THE PROTECTION OF COMMERCIAL CONFIDENTIALITY IN THE EU AND UKRAINE

\title{
ПРАВОВИЙ РЕЖИМ ЗАХИСТУ КОНФІДЕНЦЙНОӤ (КОМЕРЦІЙНОÏ) ТАЕМНИЦІ В КРАЇНАХ ЄС ТА УКРАЇНІ
}

\author{
Kuzmenko Sergey ${ }^{1}$ \\ Nadezhdenko Alina ${ }^{2}$
}

DOI: http://dx.doi.org/10.30525/978-9934-571-29-9_6

\begin{abstract}
Present research describes the current stage of scientific development of the legal framework of commercial confidentiality protection in the EU and Ukraine. Research and theoretical basis of the study consists of the research papers of Ukrainian scholars in the field of civil, business, civil procedure and commercial procedural law, private international law, constitutional and administrative law and other fields of law. Thus, the features and the notion of commercial confidentiality, analysis of the fundamental provisions of acting legislation on commercial confidentiality and main issues of its legal protection are provided in the works by V. Drobyazka, R. Drobyazka, S. Gavrina, I. Gonchar, I. Dyba, V. Ivashchenko, S. Iliashenko, O. Sergeeva, H. Sliadneva, Y. Nosik. The issues of legal protection of commercial confidentiality are studied in the works by D. Bayura, O. Bezhevets, V. Prystaiko, N. Ivanytska, L. Topalova, G. Shvets. The target of the study is the legal relations that arise from establishing the legal regime of commercial confidentiality in the EU and Ukraine, and legal regulations governing these relations and their practical application. The study focuses on legal relations that arise from establishing a legal regime for the protection of commercial confidentiality in the EU and Ukraine. The study views the concept of "commercial confidentiality" as a legal category, defines common features of commercial confidentiality that are the basis for
\end{abstract}

\footnotetext{
${ }^{1}$ Doctor of Science in Public Administration,

Candidate of Legal Sciences, Associate Professor,

Professor of the Department of Law and Public Administration,

Mariupol State University, Ukraine

${ }^{2}$ Candidate of Sciences in Public Administration,

Associate Professor, Department of Law and Public Administration,

Mariupol State University, Ukraine
}

(C) Kuzmenko Sergey, Nadezhdenko Alina 


\section{Kuzmenko Sergey, Nadezhdenko Alina}

certain legal protection. The authors prove that the European Union countries do not have a uniform act, which would have contained general mandatory European provisions on legal protection of information, sensitive information (commercial confidentiality). At the same time, some international standards for the commercial confidentiality protection are established by the Paris Convention for the Protection of Industrial Property, which captured the provisions on necessary termination of unfair competition. Comparing the legislation of Ukraine and the EU states with regard to the protection of commercial confidentiality the authors state that means of protection and the level of compliance of the Ukrainian legislation in most cases correspond to the European standards. However, the adoption of special law that will regulate the sensitive information relations in Ukraine, and commercial confidentiality in particular poses a problem. A legal framework for the protection of commercial confidentiality is still being applied, mainly through the provision of various laws, including public law.

\section{Introduction}

In terms of the existing competition between entrepreneurs, commercially val-uable information on the production technology of goods, its components, methods of minimizing the costs and growing revenue and other information, constituting commercial confidentiality provides a certain manufacturer with the advantages on the market which allows him making significant profit.

The informational orientation on the development of society and economy, the intellectualization of social production and entrepreneurship, the spread of unfair competition at national and international levels, in particular, of commercial espionage in its various forms, call the attention to the strengthening of practical interest in commercial confidentiality as one of the most effective measures of information protection, which is given a paramount priotrity by the Concept of the National Program of Informatization.

At the same time, there are some legal obstacles in Ukraine to the extensive use of commercial confidentiality legal mechanisms. There are many other obstacles to the full-scale functioning of a legal category of commercial confidentiality in Ukraine, in particular, the instability of the law on commercial confidentiality which was introduced early in the 1990s and already radically reformed (new Civil and Commercial codes of Ukraine 
were adopted). These obstacles are also the inconsistency and even the contradictory nature of provisions of certain regulatory legal acts on relations arising from commercial confidentiality; uncertainty of commercial turnover of trade secrets; the ambiguous nature and content of the right to commercial confidentiality; the lack of efficient law enforcement practice in this area, in particular, the judicial one.

The article proves that the right to commercial confidentiality is a type of intellectual property rights (exclusive rights). At the same time, commercial confidentiality is equal to the information itself and is not seen as a legal framework for the protection of this confidential information. The features of commercial confidentiality inherent in it due to the very essence of the object set special conditions of the legal protection of an object.

At the same time, one should take into account that the national legal mechanisms for the protection of confidential information (trade secrets and know-how) in Europe, in its turn, differ significantly in terms of the sources, judicial practice, standards of civil, criminal, and administrative protection, the extent of legal protection and other.

The notion of violation in terms of commercial confidentiality differs from the one of property rights or intellectual property rights. Trade secrets and know-how, as opposed to them, are granted the presumption of good faith, because any person can identify information as commercial confidentiality and keep it secret, or practically manage it. Such a person may, at its own discretion, grants access, or restricts illegal access to such information for other persons through physical acts.

These and other factors explain the need for a comprehensive scientific and theoretical study of legal nature of the rights to commercial confidentiality and a legal framework for the protection of trade secrets in the EU countries and Ukraine and thus proves the relevance of the issue discussed. In addition, the acting legislation on commercial confidentiality in Ukraine and current establishment of economic and legal security and protection of commercial sensitive information also underline the relevance of the research.

\section{Notion and features of commercial confidentiality}

Reveling the notion and features of commercial confidentiality is of high methodological importance since understanding the notion of commercial confi-dentiality itself is crucial for the content of the rights to confidential- 


\section{Kuzmenko Sergey, Nadezhdenko Alina}

ity, their in-troduction into the system of economic rights, establishing the grounds for their emergence, change and termination.

O. Kulinichi views commercial confidentiality only as an element of the in-formation with limited access [1, p. 128].

S. Shkliar, in his turn, states that «... the right of an business entity to commercial confidentiality is a subjective right of a business entity, which gives it the right to act in a certain way, in particular to determine the content of information which constitutes a trade secret, a confidentiality mode, to take measures necessary to maintain the secrecy, use and manage it, etc.; to demand that responsible persons act in accordance with the current legislation, without violating its rights; seek for the protection from authorized state bodies in case of violation of the right to commercial confidentiality, in particular, in case of illegal collection, disclosure and use of trade secrets of a business entity". The latter definition focuses not on a certain object but on the type of activities of an business entity [2, p. 11].

Authors like V. Zadiraka, O. Oleksiuk, M. Nedashkovskii believe that com-mercial confidentiality consists of economic interests coming from commercial considerations and information on various aspects and fields of financial, industrial, managerial, research and technology activities of banking institutions, firms, enterprises, companies, corporations the protection of which is determined by competition and possible threat to economic security. Commercial confidentiality appears when it is of a great interest to commerce [3, p. 184].

D. Hetmantsev describes the following main features of commercial confi-dentiality: the notion of "commercial value"; secrecy; the content and extent of trade secret is determined by the bearer of the information at his own discretion; the bearer of this trade secret has all the rights to manage it; a legal framework of commercial confidentiality is prescribed by the Commercial Code of Ukraine and the Civil Code of Ukraine; legal right of a person to trade secrets has specific legal means of protection [4, p. 14]. According to V.L. Kostiuk a trade secret is the right of a business entity (legal entities and private persons) to non-discretion, to keep the records containing their own activities or joint activities with other companions (production, trade, research and technology data, financial or other activities) secret, if this information can cause financial, material or nonmaterial damage. Administrative responsibility for violation of commercial confidentiality is envisioned by the terms of 


\section{Legal regime for the protection of commercial confidentiality in the EU...}

contracts (labor agreements) between the employer and employee of a business entity [5, p. 48].

M. Vinogradsky and O. Shkanova study the essence of the commercial confidentiality concept mentioned in the following provisions: this is any business information that has a real or potential value for an enterprise for commercial reasons, the disclosure of which may negatively affect the enterprise. It is not publicly available in legal terms. These records are appropriately marked and the company takes appropriate measures to keep its confidentiality. This information does not belong to highly classified one and is not protected by copyright and patent law. This information has nothing to do with the negative actions of an enterprise, which can harm the society (violations of laws and inefficient performance, administrative errors, environmental pollution, etc.) [6, p. 398].

At the same time, some authors, including D. Baiura, O. Bezhevets, S. Iliashenko, L. Topalov while defining the notion of commercial confidentiality in their publications, emphasize that commercial confidentiality is related to production, technical information, management, finance and other activities of an enterprise and records do not belong to the highly classified information, thus their disclosure (transmission, leakage) of which may damage its interests.

Business and civil law of Ukraine view the concept of "commercial confidentiality" as a legal category of the Civil and Commercial Codes of Ukraine that specifiy how a trade secret of an enterprise should be treated.

Thus, the Civil Code of Ukraine (Article 505) defines commercial confidentiality as secret information, in the sense that it is entirely or in a certain way and as a set of its features is unknown and not easily accessible to persons who usually deal with the type of information to which it belongs. In this regard, such information is of commercial value and is subject to secrecy protection measures consistent with existing conditions and these measures are taken by a person who legally controls this information [7].

Art. 162 of the Commercial Code of Ukraine describes the following features of commercial confidentiality, that if present (all the features must be present), are protected from the use by third parties: business information (technical, organizational, etc.); it has a commercial value as it is secret to third parties and thus does not provide other persons with a legal free access; the owner of the information takes appropriate measures to protect its confidentiality [8]. 


\section{Kuzmenko Sergey, Nadezhdenko Alina}

Based on the above-mentioned definitions of commercial confidentiality, the authors define common features of commercial confidentiality that allow for the appropriate legal protection. The above definitions of commercial confidentiality concept mention a set of features, namely: informational content of trade secrets (in the sense that a trade secret is information itself); confidentiality; commercial value; information security.

All features common to the legal category of commercial confidentiality are essential, inherent and integral. At the same time, the features like informational content and the security of information (which means that a person who legally controls this information takes measures consistent with actual circumstances aimed at the protection of its confidentiality) are the same to all types of sensitive information and, to a large extent, also to secret information. The other features of commercial confidentiality are specific. The features of confidentiality and commercial value of information, which constitute a trade secret, are external and qualitative, and informational content is an internal and essential feature.

Since legal relations arising from commercial confidentiality depend upon the existence of a set of commercial confidentiality features or the absence of at least one of them (legal relations arise if all the commercial confidentiality features are present and terminate when at least one of them is absent). The features of commercial confidentiality can be qualified as juridical facts, that once combined form a set of facts, which in their turn ground the existence of legal relations in arising from commercial confidentiality [9, p. 267].

Putting in a nutshell all the above stated, the authors conclude that legal effect of commercial confidentiality lies in: 1) establishing its legal nature; 2) defining the role of commercial confidentiality in the system of civil rights objects; 3) establishing the juridical facts necessary for the emergence, change and termination of legal relations within commercial confidentiality; 4) determining the period of trade secret legal protection.

Today, the constitutional framework of the subjective rights to information is prescribed by the art. 41 and 54 of the Constitution of Ukraine, according to which every citizen has the right to own, use and manage the results of his intellectual activity and no one is allowed to use or disseminate them without his consent, except for in cases established by law [10].

The Civil Code of Ukraine qualifies commercial confidentiality as an object of intellectual property rights (Article 420). Article 177 of the Civil 


\section{Legal regime for the protection of commercial confidentiality in the EU...}

Code of Ukraine qualifies objects of civil rights as "the result of intellectual, creative activity and information" [7].

Thus, the domestic law qualifies commercial confidentiality as the Institute of Intellectual Property Rights, that is a set of exclusive rights to intangible objects, which is the result of intellectual activity, including creative one, and other objects similar with them.

Therefore, the right to commercial confidentiality is a type of intellectual property rights (exclusive rights). At the same time, commercial confidentiality is similar to the information itself and is not seen as a legal framework for the protection of such confidential information. Following a sensible suggestion, the term "exclusive rights (intellectual property right) to commercial confidentiality" may be used to define the legal framework itself [11, p. 22].

Ukrainian legislation contains provisions on the protection of trade secrets in its legislative acts on protection against unfair competition, which is common to other countries and certain international acts (Chapter 4 of the Law of Ukraine "On Protection against Unfair Competition", Article 32, 36-37 of the Civil Code of Ukraine). At the same time, unfair competition is "illegal collection, dissemination and use of trade secrets" [12].

However, in terms of the features of a legal framework for commercial confidentiality, the protection against unfair competition should be seen only as a way to protect the rights to trade secrets, which does not change its essence.

A system of peculiar features and qualities of trade secrets can be divided into several groups: 1) those related to the properties of an object; 2) those related to the conditions of legal protection of the object; 3 ) others [13, p. 77].

Trade secrets have all the features of an immaterial object, which is subject to the simultaneous use by an unlimited number of persons, the absence of physical wear, etc.

The content and the essence of an immaterial object, i.e. the information itself, constitute a trade secret, and not their external shape (as opposed to copyright). This means that trade secrets are the objects of exclusive rights, for which the meaning of the result of intellectual activity is critical.

The features of commercial confidentiality inherent to it due to the very es-sence of the object, provide special conditions of legal protection of an object. These conditions are: the object is not widely known and accessible, same as the requirements for registration of an object; circulability. 
Another feature of commercial confidentiality is the unlimited period of its protection. The right to commercial confidentiality is preserved until a person has an actual monopoly to the information that creates it, as well as the existing conditions of its protection prescribed by the law.

\section{The legal framework for the protection of trade secrets in the EU countries and Ukraine}

In terms of legal relations related to commercial confidentiality, the issue of protection is the most important one. According to E. Izmaylova, in recent years different countries adopted many information regulations [14, p. 27].

The experience of other countries in that field is very valuable for Ukraine. For example, the EU does not provide any uniform act that would have contained general imperative European norms in the field of legal protection of information, confidential information (commercial confidentiality). Although European legislation still regulates certain issues, for example, the Directive 95/46 / EC of the European Parliament and of the European Council of 24.10.1995 on the protection of individuals with regard to the processing of personal data and on the free movement of such data [15] resolved that personal data access is not to compromise commercial secrets [16, p. 48].

Directive 97/66 / EC of the European Parliament and of the European Council of 15.12.1997 concerning processing of personal data and the protection of privacy in the electronic communications sector [17] provides for the infor-mation (confidential information) "access right", for example, personal data, adherence to the privacy conditions while reporting personal data, the protection of fundamental rights and freedoms and legitimate interests in electronic communications sector, etc. The disclosure of sensitive information (trade secrets) in e-commerce, such as access to commercial messages, terms of sending commercial messages and the confidentiality of a process is regulated by Directive 2000/31 / EC of the European Parliament and of the European Council of June 8, 2000 on certain legal aspects of information society services, in particular electronic commerce ("Directive on e-commerce") [18].

International legislative and regulatory acts are also important while establishing international standards for sensitive information protection (trade secrets, know-how). The Agreement on Trade-Related Aspects of 
Intellectual Property Rights (TRIPS Agreement) and North American Free Trade Agreement (NAFTA Agreement) hold a specific place among them. They are quite similar and are one the first multilateral international agreements that are directly aimed at creating a single mechanism for the sensitive information protection (trade secrets and know-how). These two agreements are examples of universal and regional harmonization of law. The NAFTA agreement extends to Canada, the United States and Mexico. The TRIPS Agreement sets standards for the protection of intellectual property rights and coercion measures aimed at observation of these rights among the WTO member states [19, p. 29], including Ukraine. Thus, studying the provisions of this Agreement on sensitive information (trade secrets and know-how) is not only of theoretical but also practical importance. One should mention the Model Regulations for the Protec-tion Against Unfair Competition, designed by the World Intellectual Property Organization (WIPO) in 1996, which provides for the protection of confidential information.

One should bear it in mind, however, that the national legal mechanism for the protection of sensitive information (trade secrets and know-how) in Europe differs considerably in terms of sources, cases, civil, criminal, administrative protection provisions, extent of legal protection etc.

International standards for the protection of trade secrets are set forth in the Paris Convention for the Protection of Industrial Property [20], which enshrines the provisions on binding termination of unfair competition. The Art. 10bis of the Convention stipulates that the countries of the Union are bound to assure to nationals of such countries effective protection against unfair competition (paragraph 1).

Comparing the legislations of Ukraine and the EU regarding the protection of trade secrets, the authors note that the means of protection and level of responsibility, provided by the Ukrainian legislation are basically the same as those provided by European standards. However, the definition of trade secrets and the role of this institution in the legislation are still challenging. Therefore, in our opinion, the legislation on sensitive information (trade secrets and know-how) of Ukraine requires upgrades and further development, as it has a number of drawbacks and contradictions contained in provisions of various laws and regulations. Such development should be inseparable from the processes of harmonization and adaptation to international legal and European standards in the field of protection of sensitive 
information (trade secrets and know-how), in particular, by adopting a special omnibus law on trade secrets.

The issue of adopting a special law which would regulate relations arising from sensitive information, in particular commercial confidentiality, were widely discussed by Ukrainian scholars. However, legal regulation of commercial confidentiality is still carried out mainly according to the provisions of various legislations, including public law. Given this, it is advisable to adopt a special Law of Ukraine "On Commercial Confidentiality", which will enshrine provisions on: 1) the concept and terms of the protection of commercial confidentiality; 2) information which cannot be classified as a trade secret; 3 ) regulation of trade secrets access right; 4) the terms of protection and responsibility for violation of legally protected interests of a person who practically controls this information. We believe that this (special) Law of Ukraine "On Commercial Secrets" should appear in the system of legislation at a lower level, in relation to the higher one, which is the Civil Code of Ukraine (Art. 505-508).

Since the informational type of society was established in Ukraine, the protection of the rights to information resources of different levels of access became more relevant. And it's quite natural that it has heightened practical interest in commercial confidentiality and other related concepts as one of the effective measures of information security [21, p. 9].

Moreover, the Supreme Economic Court of Ukraine qualifies sensitive information in the field of economic (business) activity as recognized as such by the law (Article 862 of the Civil Code of Ukraine), trade secrets (Articles 505-508 of the Civil Code of Ukraine) and "know-how" (Article 1 of the Law of Ukraine No. 1560-XII of September 18, 1991 "On Investment Activity") [22, p. 46].

That is, commercial confidentiality belongs to the sensitive information not owned by the state.

There is no Law on Commercial Confidentiality Protection in Ukraine today. Lawyers point out that the main obstacle to the formation of Law is that trade secret information is not subject to record due to its confidentiality. For this reason there are no protective documents granted to it. Moreover, it is almost impossible to detect the illegal use of such information, and to establish the violation or find a law breaker. 


\section{Legal regime for the protection of commercial confidentiality in the EU...}

\section{The right to use trade secrets}

The issue of commercial confidentiality is of practical importance. Some years ago scholars talked only about the research and theoretical aspect of trade secrets of business entities. Today, the issue of protecting internal secrets of enterprises are among the most relevant ones [23, p. 35].

In economic law, "use" is a legal power of an owner to take advantage of useful qualities and properties of an object that belongs to it to meet the needs of the owner [24, p. 269, 294].

"Use" in terms of the intellectual property right is understood as an object itself, which is the result of intellectual, creative activity. The object of use is records containing the information on achievements which is not intended for pure understanding but includes recommendations for practical application, preconditioned by storing this information in tangible form or by their objective formulation [25, p. 121].

Law does not establish this ban as for a trade secret. A person in charge of commercial confidentiality should take appropriate measures to keep it secret, that is to say, to nip its divulgation, to limit the access to such information, which is a kind of activity itself. V. Kossak and I. Yakubivsky define the content of the right to use trade secrets as the right of a subject to gain an advantageous effect from the use of information in its activities which is a trade secret [26, p. 462].

The Commercial Code of Ukraine stipulates that the right to use trade secrets is not construed as exclusive right, as opposed to the right to allow the use of trade secrets and the right to prevent the illegal gathering, divulgation or use of trade secrets. Consequently, the legislator itself does not qualify it as an exclusive right, and this is right, since it may be exercised not only by one person who actually manages such information, but also by other persons (Part 3 of Article 162 of the Civil Code of Ukraine). Thus, the consolidation of a legal monopoly on information which constitutes trade secret is not foreseen by the legislation of Ukraine.

\section{Exclusive right to prevent illegal disclosure, collection or use of trade secrets}

Based on the analysis of this right, the illegal disclosure, collection, or use of trade secrets is a disservice to a person who actually controls such information. 
Interest protected by law involves taking necessary measures by a person in charge of the commercial confidentiality on the prevention of disservice. Moreover, such actions are aimed at protection of legitimate interests. For example, it could be the introduction of organizational, legal, cryptographic mechanisms for the protection of information, which constitutes a trade secret, as well as drawing up certain trade secret non-disclosure (confidentiality) agreements, or the incorporation of these provisions into employment contracts with employees.

At the same time, a person managing trade secrets is obliged to adhere to the general provisions of acting legislation on the limits of exercising the civil rights (Article 13 of the Civil Code of Ukraine), in particular to refrain from actions that violate the rights and interests of others or harm the environment or society.

Under the property law, illegal disclosure, collection or use of trade secrets is an obligation of a person as well, and the failure to perform it may break the mode of commercial secrecy (confidentiality). A person in charge of commercial confidentiality may apply these measures only to a mala fide purchaser or a person who has illegally gained access to trade secrets.

Thus, trade secret access right is based on the principles of confidentiality. That means that the abovementioned types of sensitive information exist as long as their records remain confidential (not publicly accessible). Consequently, we argue that it is not a trade secret which is protected but a legitimate interest of a person who actually controls this information.

\section{Features of commercial confidentiality protection in the $\mathbf{E U}$ countries and Ukraine}

Usually, the rights or legitimate interests require protection if they have already been violated or there exists a real threat of their violation. At the same time, the violation of commercial confidentiality is understood in a different way than real rights or intellectual property rights. For example, as for the works or inventions there is always a presumption of bad faith for their use by third parties, unless other is established by the agreement with a copyrighter or by the law. Therefore, the liability incurs regardless of the fault. Unlike them, trade secrets and know-how come along with a presumption of good faith, since any person can identify information as a commercial confidentiality and keep it secret which means to practically 
control it. This person may grant access or limit the illegal access to such information for other persons by taking actions.

Legal protection of interests is carried out through application of the appropriate forms, means and methods. There are non-jurisdictional and jurisdictional forms of protection of intellectual property rights, or better said judicial and administrative ones and self-defence [27, p. 683-684].

One can say that a form of protecting commercial confidentiality is mainly jurisdictional one (in a court). Self-defence is also possible but only if that does not involve the abuse of rights. In this case, self-defence is narrowed down to the unrestricted neutralization and deactivation of technical equipment illegally installed by third parties for the purpose of obtaining information, as well as taking prompt measures to misinform persons who got illegal access to secret records in order to prevent possible losses from their disclosure. Self-defence may entail certain penalties for commercial contracts partners and employees who violate the obligation not to disclose sensitive information.

Legal protection of person's interests in charge of confidential information (trade secret, know-how) may be carried out through: 1) the application of the legislation on unfair competition, or 2) the application of economic and civil law and through the means prescribed by the economic and civil legislation of Ukraine (Article 20 of the Civil Code of Ukraine, Article 16 of the Civil Code of Ukraine and other means directly specified in the law).

The protection of commercial confidentiality (confidential information) under the international standards is an integral part of protection against unfair competition and is carried out in accordance with Art. 10-bis ("Unfair competition") and Art. 10-ter ("Marks, Trade Names, False Indications, Unfair Competition: Remedies, Right to Sue") of the Paris Convention for the Protection of Industrial Property. Moreover, it may seem that measures prescribed by the legislation on unfair competition are designed for protecting the "rights to" commercial confidentiality and the "rights to" commercial confidentiality (confidential information) are elements of legislation on the prevention of unfair competition. However, we should mind the difference between the rights and ways of protecting them, when unfair competition is only one of the means of protecting rights, and not the rights themselves, and the rights protected differ from the rights to sensitive information. At the same time, even if taking into account only the means of protection, the law on unfair competition as such does not perform the 


\section{Kuzmenko Sergey, Nadezhdenko Alina}

function of protecting "rights" or the legally protected interests to commercial confidentiality exercised by a person, though makes reference to general civil law.

The Law of Ukraine "On Protection Against Unfair Competition" dated June 7, 1996 (hereinafter referred to as the Law) [12] stipulates the efforts related to commercial confidentiality that are qualified as unfair competition and provides for certain level of amenability. One may say that unfair competition being a type of activities and actions of a person in charge of commercial confidentiality aimed at securing its secrecy, is also a type of activity. The law distinguishes four categories of offenses: 1) illegal collection of trade secrets (Article 16); 2) disclosure of trade secrets (Article 17); 3 ) propensity to disclose trade secrets (Article 18); 4) illegal use of trade secrets (Article 19). The law defines forms of unfair competition and specific consequences of wrongdoing in the field of commercial confidentiality such as fines or compensation for losses (Article 20).

If a person controlling commercial confidentiality was inflicted damage by wrongdoing in the form of unfair competition, it can file a claim with a court for damages in accordance with the procedure established by the Civil Law of Ukraine (Article 24). One can note that it refers to the civil law when a person is inflicted damage. Therefore, a person who actually controls sensitive information (trade secret, know-how) should first be applied to the Antimonopoly Committee of Ukraine and not to a court. And only after that, this person can file a claim with a court for compensation for losses. In this case the subject is a business entity.

Art. 16 of the Civil Code of Ukraine and Art. 20 of the Civil Code of Ukraine provide a comprehensive list of ways to protect rights and interests. However, not all of them can be applied to sensitive information (trade secrets and know-how), because the nature of the violated interest of a person and the nature of the violation itself provides certain options.

For violation of rights of business entities as for commercial confidentiality, a guilty person may bear legal responsibility for various types: civil liability in the form of compensation for damage done to an entity in accordance with the Civil Code; disciplinary and financial responsibility under the Labour Code of Ukraine; administrative liability established by Part 3 of Article 164-3 of the Code of Ukraine on Administrative Offenses (CU-AO); criminal liability in accordance with art.231,232 of the Criminal Code of Ukraine (CCU). In addition, Article 21.22 of the Law of Ukraine 


\section{Legal regime for the protection of commercial confidentiality in the EU...}

"On Protection against Unfair Competition" establishes administrative and economic fines for unfair competition manifested as illegal collection, disclosure, and propensity to disclose and use trade secrets.

However, despite certain positive aspects, none of these actions fully corre-sponds to a bill on the protection of the rights to commercial confidentiality [28]. This requires: passing and systematizing the legislation on commercial confidentiality, its amendments and annexes; designing a single approach to the protection of trade secrets as an element of an intellectual property legislation; determining legal foundation for qualifying information as a trade secret; establishing responsibility for violation of intellectual property rights to commercial confidentiality, etc.

Taking into account the shortcomings of acting legislation on commercial confidentiality and the latest tendencies in world experience, many experts believe that the main burden of the implementation of the second component of the legal institution of commercial confidentiality (legal mechanism for its protection) should be transmitted to the sphere of local statutory instruments and legal regulation of employer-employee relations.

These instruments may include: statute of the enterprise; foundation agree-ments; Collective agreement; internal work regulations, job instructions, etc., where the provisions on commercial confidentiality are only one of the elements of their content. Other local acts, such as the Commercial Confidentiality Regulations and the rules for observing its confidentiality, the provisions on the performers access system to documents and information that constitute a trade secret of an enterprise, a supplementary agreement to the employment agreement (contract), etc. are specific and only refer to commercial confidentiality issues.

Article 162 of the Commercial Code of Ukraine defines that an business entity that owns technical, organizational or other commercial information has the right to protection against the illegal use of this information by third parties if this information is of commercial value and given that it is secret to third parties and does not provide the free legal access to other persons, and the owner of the information takes appropriate measures to protect its confidentiality. The period of legal protection of trade secrets is limited.

Therefore, it is sure that the content and extent of information constituting trade secret and its protection procedure are established solely by its owner or the executive of an enterprise in accordance with the acting legislation. 


\section{Kuzmenko Sergey, Nadezhdenko Alina}

An enterprise has the right to manage such information at its own discretion and to carry out any lawful acts directed to it, however, without violating the rights of third parties.

Moreover, an enterprise as the owner of the information (i.e. trade secret) has the right to appoint a person who will own, use and manage such information, to set the rules for processing information and getting access to it, and also to establish other commercial confidentiality conditions.

\section{Conclusions}

The research allows drawing the following conclusions:

1. Based on the above mentioned definitions of the concept of "commercial confidentiality", the authors define common features of commercial confidentiality which are the basis for certain legal protection. Thus, the content of the notion of commercial confidentiality is characterized by the set of features, such as: informational content of trade secrets (that is to say that trade secrets are information); confidentiality; commercial value; security of information.

2. The authors question the practicability of adopting a special Law of Ukraine "On Commercial Confidentiality", which will enshrine the provisions on: 1) the notion and conditions defining the protectability of commercial confidentiality; 2) information which cannot be classified as trade secret; 3) regulation of trade secrets "access right"; 4) the protection conditions and responsibility for violation of "interests protected by law" of a person who is actually in charge of such information.

3. The authors prove that the main obstacle to the formation of Law is that trade secret information is not subject to record due to its confidentiality. For this reason there are no protective documents granted to it. Moreover, it is almost im-possible to detect the illegal use of such information, and to establish the violation or find a law breaker.

4. Trade secret access right is based on the principle of confidentiality. That is, the abovementioned types of sensitive information exist as long as their records remain confidential (not publicly accessible). Consequently, we can say that it is not a trade secret which is protected but a legitimate interest of a person who actually controls this information.

5. The authors prove that the shortcomings of acting legislation on commercial confidentiality and the latest tendencies in world experience, many experts believe that the main burden of the implementation of the 


\section{Legal regime for the protection of commercial confidentiality in the EU...}

second component of the legal institution of commercial confidentiality (legal mechanism for its protection) should be transmitted to the sphere of local statutory instruments and legal regulation of employer-employee relations.

6. The authors prove that the content and extent of information constituting trade secret and its protection procedure are established solely by its owner or the executive of an enter-prise in accordance with the acting legislation.

\section{References:}

1. Kulinich O.O. (2005) Informatsiia yak obiekt tsyvilnykh prav [Information as a civil rights object ]. University Scientific Proceedings, vol.3, no. 15, pp. 126-128.

2. Shkljar S.V. (2008) Pravovi aspekty rehuliuvannia vidnosyn, poviazanykh $\mathrm{z}$ komertsiinoiu taiemnytseiu [Legal aspects of regulating relations related to commercial confidentiality]. Intellectual Property, no.7, pp. 9-15.

3. Oleksiuk O.S., Nedashkovskyi M.O., Zadiraka V.K. (1999) Metody zakhystu bankivskoi informatsii: Navchalnyi posibnyk [Methods of bank infor-mation protection: Textbook]. Kyiv: Vyshcha shkola (in Ukrainian).

4. Hetmantsev D.O. (2008) Do pytannia pro pravovyi rezhym komertsiinoi taiemnytsi za za-konodavstvom Ukrainy [On legal framework for commercial confidentiality according to the legislation of Ukraine]. Lawyer, vol. 5, no. 92, pp. 14-15.

5. Kostiuk V.L. (2005) Problemni pytannia zastosuvannia polozhen shchodo komertsiinoi taiemnytsi $\mathrm{v}$ trudovomu dohovori [Challenges arising from applying provisions on commercial confidentiality]. Bulletin of the Ministry of Justice of Ukraine, vol. 2, no. 40, pp. 46-52.

6. Vynohradskyi M.D., Shkanova O.M. (2002) Orhanizatsiia pratsi menedzhera: navch. posibnyk. [Organizing the managerial activities:Textbook]. Kyiv: Kondor (in Ukrainian).

7. Tsyvilnyi kodeks Ukrainy vid 16 sichnia 2003 roku \# 435-IV (2003) [Civil Code of Ukraine dated January $16^{\text {th }}, 2003 \# 435$-IV]. Journal of the Verkhovna Rada of Ukraine. №№ 40-44, Art.356.

8. Hospodarskyi Kodeks Ukrainy vid 16 sichnia 2003 roku \# 436-IV (2003) [Commercial Code of Ukraine dated January $16^{\text {th }}, 2003$ \# 436-IV]. Journal of the Verkhovna Rada of Ukraine. № 18, № 19-20, № 21-22, Art.144.

9. Nosik Yu.V. (2005) Yurydychne znachennia oznak komertsiinoi taiemnytsi / [Legal meaning of the fetures of a trade secret]. Proceedings of Mizhnarodna naukova konferentsiia studentiv ta aspirantiv (Ukraine, Kyiv, Khmelnytskyi, November 25-26, 2005), Khmelnytskyi: Khmelnytsky University of Management and Law, pp. 266-268.

10. Konstytutsiia Ukrainy vid 28 chervnia 1996 roku (1996) [Constitution of Ukraine dated August 28 ${ }^{\text {th }}$, 1996]. Journal of the Verkhovna Rada of Ukraine, no. 30, Art. 141. 


\section{Kuzmenko Sergey, Nadezhdenko Alina}

11. Postul'ga V. (2003) Nekotorye aspekty pravovogo statusa informatsii s ogranichennym dostupom [Certain aspects of legal status of information with legal access]. Legal Practice, № 11, pp. 21-24.

12. Pro zakhyst vid nedobrosovisnoi konkurentsii: Zakon Ukrainy vid 07 chervnia 1996 roku \# 236/96-VR (1996) [On protection against unfair competition: Law of Ukraine dated January $\left.7^{\text {th }}, 1996\right]$. Journal of the Verkhovna Rada of Ukraine № 36. pp. 164.

13. Severin V.A. (2001) Pravovaya zashchishchennost' kommercheskoy tsennoy informatsii [Legal security of commercially valuable information]. Journal of Moscow University, № 6, pp.76-85

14. Izmaylova E.V. (2005) Informatsiya v kommercheskikh otnosheniyakh [Information and commercial relations]. Journal of Moscow University, series “Law”, № 1, pp. 26-29.

15. Ofitsiina zbirka normatyvnykh aktiv Yevropeiskoho Soiuzu $\mathrm{v}$ sferi informatsiino-komunikatsiinykh tekhnolohii (2002) Dyrektyva 95/46/YeS Yevropeiskoho Parlamentu i Rady vid 24.10.1995 r. "Pro zakhyst fizychnykh osib pry obrobtsi personalnykh danykh i pro vilne pe-remishchennia takykh danykh" [European Parliament and Council Directive 95/46/EC of 24 October 1995 on the protection of individuals with regard to the processing of personal data and on the free movement of such data], Kyiv: Interniuz Ukraina.

16. Bryzhko V. (2004) Do pytannia shchodo mizhnarodnykh standartiv zakhystu danykh [Issues of international standards for data protection]. Legal informatics, № 2, pp. 48-49.

17. Ofitsiina zbirka normatyvnykh aktiv Yevropeiskoho Soiuzu v sferi informatsiino-komunikatsiinykh tekhnolohii (2002) Dyrektyva 96/9/YeS Yevropeiskoho Parlamentu ta Rady vid 11.03.1996 r. "Pro pravovyi zakhyst baz danykh" [European Parliament and Council Directive 96/9 / EC of the European Parliament and of the Council of 11.03.1996 "On the legal protection of databases"], Kyiv: Interniuz Ukraina.

18. Ofitsiina zbirka normatyvnykh aktiv Yevropeiskoho Soiuzu v sferi informatsiino-komunikatsiinykh tekhnolohii (2002) Dyrektyva 2000/31/YeS Yevropeiskoho parlamentu ta Rady vid 8.06.2000 r. "Pro deiaki pravovi aspekty informatsiinykh poslu, zokrema, elektronnoi ko-mertsii, na vnutrishnomu rynku" ("Dyrektyva pro elektronnu komertsiiu") [Directive 2000/31/EC of the European Parliament and of the Council of 8 June 2000 on certain legal aspects of information society services, in particular electronic commerce, in the Internal Market ('Directive on electronic commerce')], Kyiv: Interniuz Ukraina.

19. Androshchuk A. (1999) Sekretna informatsiia yak obiekt pravovoi okhorony [Sensitive information as an object of legal protection]. Intellectual Property, № 3-4, pp. 27-32.

20. VOICE (1990) Parizhskaya konventsiya po okhrane promyshlennoy sobstvennosti. Ofitsial'-nyy russkiy tekst [Paris Convention for the Protection of Industrial Property. Official Russian Text]. Geneva: Voice. (in Russian).

21. Sheveleva T. (2008) Pravovi aspekty rehuliuvannia vidnosyn, poviazanykh z komertsiinoiu taiemnytseiu, v proekti Zakonu Ukrainy "Pro okhoronu prav na komertsiinu taiemnytsiu" [Legal aspects of regulating relations related to 


\section{Legal regime for the protection of commercial confidentiality in the EU...}

commercial confidentiality in a bill of Ukraine on Protection of rights to commercial; confidentiality]. Intellectual Property, № 7, pp. 9-15.

22. Pro deiaki pytannia praktyky zastosuvannia hospodarskymy sudamy zakonodavstva pro informatsiiu: Informatsiinyi lyst Vyshchoho hospodarskoho sudu Ukrainy vid 28.03.2007 \# 01-8/184 (2007) [Certain issues of practical application of legislation on information by economic courts: Leaflet of Higher Economic Court of Ukraine dated 28.03.2007 \# 01-8/184]. Journal of Economic Proceedings, № 3, pp. 46.

23. Marushchak A. (2006) Naukovo-praktychni aspekty zberezhennia komertsiinoi taiemnytsi na pidpryiemstvi [Scientific and practical aspects of protecting commercial confidentiality at an enterprise]. Legal Adviser, vol. 2, No 10 , pp. 35-38.

24. O.P. Orliuk, H.O.Androshchuk, O.B. Butnik-Siverskyi et al., O.A. Pidopryhory, O.D. Sviatotskyi (ed.) (2002) Pravo intelektualnoi vlasnosti: Akadem. kurs: [pidruchnyk dlia stud. vyshchykh navch. zakl.] [Intellectual property right: academic course [textbook for higher education institutions students]]. Kyiv: In Yure. (in Ukrainian).

25. Dozortsev V.A., Litovkin V.A. (ed.) (2000) Ponyatie "isklyuchitel'nykh prav" kak osoboy kategorii [Notion of exclusive rights as a special category]. Problemy sovremennogo grazhdanskogo prava: [sb. nauch. statey] [Problems of acting Civil Law [collection of scientific articles]. Moscow: Gorodets, p. 384.

26. V.M. Kossak (ed.) (2004) Naukovo-praktychnyi komentar Tsyvilnoho kodeksu Ukrainy [Theoretical and practical commentary on Civil Code of Ukraine]. Kyiv: Istyna. (in Ukrainian).

27. Sergeev A.P. (1999) Pravo intellektual'noy sobstvennosti v Rossiyskoy Federatsii [uchebnik, 2-e izd., pererab. i dop.] [Intellectual Property Right in Russian Federation [textbook, $2^{\text {nd }}$ edition, revised]]. Moscow: Prospekt. (in Russian).

28. Kontseptsiia proektu Zakonu Ukrainy "Pro okhoronu prav na komertsiinu taiemnytsiu [Draft bill of the Law of Ukraine on Commercial Confidentiality Rights Protection]. Available at: http: // zakon.rada.gov.ua/laws/show/1404-2008-p (accessed 27 January 2018). 


\title{
THEORETICAL AND METHODOLOGICAL BASIS OF IMPLEMENTATION OF THE FOREIGN EXPERIENCE OF ADMINISTRATIVE REGULATION IN THE SYSTEM OF PUBLIC ADMINISTRATION
}

\section{ТЕОРЕТИКО-МЕТОДОЛОГІЧНІ ЗАСАДИ ІМПЛЕМЕНТАЦЇ̈ ЗАРУБІЖНОГО ДОСВІДУ АДМІНІСТРАТИВНОГО РЕГУЛЮВАННЯ В СИСТЕМІ ПУБЛІЧНОГО УПРАВЛІННЯ}

\section{Lozytska Iryna ${ }^{1}$ \\ Bashtannyk Vitalii ${ }^{2}$}

DOI: http://dx.doi.org/10.30525/978-9934-571-29-9_7

\begin{abstract}
The article examines various approaches to the principles of administrative reform of public administration based on the introduction of foreign experience. This study is based on the use of a set of general scientific and special scientific methods. The basis of the methodology of the article is a systematic approach, methods of analysis and synthesis, generalizations, comparative-historical method in accordance with the subject of research. The system approach allowed to study the basic components of the process of implementing the foreign experience of administrative reform through their internal integration. The application of the system approach allows us to analyse the organizational and legal foundations of the activity of the subjects of state administration, their functional characteristics and characteristics, and the tendencies of administrative regulation in the system of government bodies. The use of the comparative-historical method and the system approach was based on information systematized according to the criteria of analysis in accordance with the nature of the study.

The purpose of the study in the article is the development of organizational and institutional foundations and practical justification for the

\footnotetext{
${ }^{1}$ Postgraduate Student of the Department of Law and European Integration,

Dnipropetrovsk Regional Institute of Public Administration

of the National Academy of Public Administration under of the President of Ukraine;

Dnipropetrovsk District Administrative Court, judge, Ukraine

${ }^{2}$ Doctor of Science of Public Administration, Professor,

Professor of the Department of Law and European Integration,

Dnipropetrovsk Regional Institute of Public Administration

of the National Academy of Public Administration under of the President of Ukraine
} 
introduction of foreign experience of administrative reform in Ukraine. This goal is achieved through the implementation of research tasks: first, to analyse the peculiarities of the foreign experience of administrative reform and to determine on this basis the content and features of the administrative reform of the public administration in Ukraine; to reveal the importance of organizational and institutional support for the implementation of the administrative reform to improve the system of public authority, clarify the role of the legislative and legislative process to promote the implementation of administrative reform measures; to determine the actual problems of legal support for modern administrative reform in Ukraine.

Two key features of the introduction of foreign experience of administrative reform are underlined. First, the institutional definition of the legal framework (principles, methods and forms) of the functioning of the system of public administration. Secondly, the formation of the basis for the activities of government bodies in accordance with the concept of multi-level management.

The article presents conceptual approaches to the organizational principles of implementing foreign experience in the practice of public administration in Ukraine. A deepening of the research of reforming the system of public administration in the following areas is proposed: public administration as a system of public relations; ensuring human rights and freedoms as a vector of humanizing management; political and administrative aspects of the activities of government bodies; constitutional and legal bases of public administration in the context of supranational integration processes; analysis and adaptation of foreign experience in the transformation of public administration; development of regional and sectoral management in accordance with the requirements of EU law.

It is argued that the European integration processes contributed to the emergence of fundamentally new institutions of power and administrative mechanisms for coordinating positions and developing joint approaches to solve regional and global problems. Under such conditions, public administration in the process of reforming acquires new distinctive features, its subjectivity increases, and integrative management characteristics are strengthened. That is why the current state of the reform of the authorities is conditioned by the formation of an open administrative system, in which the principles, instruments, forms and methods of territorial government are constantly harmonized, the institution of delegation of authority is devel- 
oping, in accordance with the phenomenon of delegated management as an imperative of the general policy within the European Union.

It is established that in the process of studying foreign experience it is important: first, to analyse the peculiarities of the foreign experience of administrative reform and to determine on this basis the content and peculiarities of the administrative reform of the public administration system in Ukraine; secondly, to identify the importance of organizational support for the implementation of administrative reform to improve the system of state power, the role of the regulatory and legislative process in order to facilitate the implementation of administrative reform; thirdly, to determine the current problems of institutional provision of modern administrative reforms in Ukraine.

\section{1. Вступ}

Актуальність теми дослідження теоретико-методологічні засади імплементації зарубіжного досвіду адміністративного реформування в умовах децентралізації влади в Україні, загалом зарубіжного досвіду адміністративного реформування, визначення організаційних та інституціональних засад теоретичного аналізу такого досвіду пов'язана 3 тим, що за 27 років незалежності України, як свідчать реалії сьогодення, не вдалося побудувати достатньо функціональну та усталену систему публічної влади, яка була б покликана здійснювати публічно-управлінські функції та надання якісних публічних послуг громадянам України. Такий стан речей обумовлений перш за все, недосконалістю багатьох елементів механізму державного управління, який дістався у спадок від адміністративного режиму радянських часів. Подолати багато недоліків у сфері сучасного публічного адміністрування можливо шляхом здійснення адміністративної реформи, метою якої $є$ поетапне створення на наукових засадах ефективної і демократичної системи державного управління, що має бути достатньо прозорою для громадськості, максимально наближеною до потреб людини, а витрати на іï утримання повинні відповідати фінансово-економічному становищу держави.

Адміністративна реформа виступає одним з напрямів реалізації запропонованої Президентом України Стратегії сталого розвитку [1], що поєднує сучасні концепти «європеізації» публічного управління, формування нової парадигми публічного управління на основі прин- 
ципів New public management, раціонального реагування на зовнішні та внутрішні виклики. Разом з тим, реалізація реформи може бути забезпечена у процесі вирішення проблеми поєднання у часі та у просторі таких інтегративних завдань: формування ефективної системи виконавчої влади на всіх рівнях управління, формування сучасної моделі місцевого самоврядування; формування умов взаємодії виконавчої влади та місцевого самоврядування на основі принципу субсидіарності. У такому форматі важливо врахувати зарубіжний досвід багаторівневого управління, формалізацію феномену делегування повноважень, проведення адміністративно-територіальної реформи тощо

Основу методології статті становлять системний підхід, методи аналізу і синтезу, узагальнення, компаративно-історичний метод відповідно до предмета дослідження. Системний підхід дав змогу дослідити базові елементи державного управління у взаємодії з іншими елементами політичної системи через їх внутрішню інтеграцію. Застосування системного підходу не лише дало змогу проаналізувати організаційно-правові засади діяльності в державному управлінні, їх функціональні ознаки й характеристики, а й визначити загальні тенденції реформування управління. Використання компаративно-історичного методу та системного підходу базувалося на інформації, систематизованої за критеріями аналізу відповідно до характеру дослідження.

У статті також використані класичні наукові принципи об'єктивності та історизму, інші дослідницькі методи: інструментальний, інституційний, соціологічний, аксіологічний, діяльнісний, статистичної обробки емпіричного матеріалу, особистого спостереження та низка інших. Важливим методом дослідження є аналіз фактологічної та емпіричної інформації органів державного управління, результатів соціологічних досліджень для визначення актуальних напрямів підвищення ефективності державного управління в процесі реформування 3 метою врахування тенденцій до змін суспільних відносин.

Так само доцільним було застосування ситуаційного методу, який грунтується на аналізі конкретних ситуацій, виявленні обставин, що впливають на співвідношення національних інтересів у сфері зовнішніх відносин та умов їх реалізації, зокрема виокремлення європейського вибору як основи державотворення в Україні. Кожен із методів у конкретному випадку внаслідок інтегративного підходу до вивчення 
проблеми використовувався не окремо, а в поєднанні з іншими. Варто виокремити два ключових напрями впровадження зарубіжного досвіду адміністративного реформування. По-перше, організаційний, що передбачає визначення основ (принципів, методів та форм) функціонування системи органів влади. По-друге, інституціональний, що визначає сутність діяльності інститутів державного управління та інститутів громадянського суспільства.

У контексті дослідження також слід відзначити роботу Р. Войтович, присвячену дослідженню теоретичних засад глобалізації та іiі впливу на систему державного управління [2]. Зокрема, автор наголошує на необхідності визначення пріоритетів суспільного розвитку як результату впливу глобалізації на систему державного управління. Так само, Р. Войтович вказує на гіперболізацію процесу глобалізму, що провокує ситуацію невизначеності для всієї системи державного управління, й одночасно - на необхідність формування захисних механізмів державного управління [3, с. 322]. Погоджуючись із наведеними підходами провідних науковців, відзначимо, що на даному етапі процеси якісних змін (трансформацій) у національних системах управління є вторинними, і залежать від комплексу факторів внутрішнього та зовнішнього впливу, й окрім глобалізації, факторами ризику для національних держав виступають проблеми самоідентифікації держав, гомогенності національної культури, питання забезпечення національної безпеки.

Разом з тим, рівень наукового опрацювання сучасних процесів адміністративного реформування в контексті використання зарубіжного досвіду потребує більш грунтовного дослідження. Не повною мірою розкриті питання щодо визначення пріоритету впровадження такого досвіду, не визначені адаптаційні інструменти впровадження досвіду реформування, потребують подальшого вдосконалення й методологічні та організаційно-правові засади розробки нормативно-правових документів щодо імплементації зарубіжного доробку у сфері нормотворення для реалізації напрямів адміністративної реформи (розробка, закріплення у нормативних актах, визначення шляхів реалізації відповідних концепцій, стратегій, планів тощо).

Загальною метою дослідження у статті виступає напрацювання організаційних та інституціональних засад впровадження зарубіжного досвіду адміністративного реформування в Україні. Зазначена мета досягається шляхом виконання дослідницьких завдань: по-перше, 
проаналізувати особливості зарубіжного досвіду адміністративного реформування й визначити на цій основі зміст та особливості адміністративного реформування системи державного управління в Україні; розкрити значення організаційного забезпечення здійснення адміністративної реформи для вдосконалення системи публічної влади, роль нормотворчого та законотворчого процесу щодо сприяння реалізації заходів адміністративної реформи; визначити актуальні проблеми інституціонального забезпечення сучасного адміністративного реформування в Україні. Разом з тим, потребують власного вирішення комплекс дослідницьких завдань сучасної юридичної науки у контексті впровадження зарубіжного досвіду (компаративно-адаптаційний підхід). Зокрема, важливо:

- визначити тенденції та особливості впливу сучасних європейських процесів на систему державного управління, у тому числі впливу концептів Європейського адміністративного простору на розвиток національної правової системи;

- уточнити зміст, сутність та правову природу парадигми публічного управління, напрями його сучасного розвитку і на цій основі теоретично обгрунтувати концепцію реформування системи національного права;

- систематизувати сучасні підходи до розподілу управлінських повноважень між різними рівнями публічного управління, дати характеристику основних функцій органів влади на національному та регіональному рівнях у системі завдань формування державної політики і на цій основі обгрунтувати необхідність дослідження інституту делегованого управління та делегованих повноважень;

- охарактеризувати політико-правові механізми гарантування, та захисту прав людини у контексті гуманізації державного управління.

Таким чином, мова йде про виокремлення системного дослідження реформування публічного управління, в основу якого покладено компаративно-адаптаційну модель реформування та принцип гуманізації державного управління. Водночас, доцільно обгрунтувати узагальнений комплекс засобів удосконалення публічного управління на наддержавному, центральному, регіональному й галузевому рівнях через поєднання технологій соціально-економічного розвитку й організаційно-управлінських механізмів, а також дослідити їх специфічні зв'язки. При цьому сутність інструментів адміністративно-правового регулю- 
вання таких процесів визначено через обгрунтування їх імперативного характеру та можливості застосування інноваційних механізмів адміністративного регулювання.

\section{2. Особливості впровадження зарубіжного досвіду адміністративного реформування: організаційні \\ та інституціональні засади}

2014 року почався новий етап адміністративної реформи, у межах якого проведені фундаментальні зміни в системі органів державної влади. Ініційований Президентом України новий курс на модернізацію всієї системи потребує насьогодні у першу чергу принципово нового підходу до адміністративного реформування, розробки концепції формування відкритої системи публічного управління на основі сучасних європейських принципів адміністрування. Важливим завданням формування організаційно-правових засад державного управління в Україні є приведення системи влади у відповідність до світових (європейських) стандартів суспільного управління, 3 урахуванням національних інтересів і процесів структурування наднаціональних систем.

Слід зазначити, що більшість дослідників виходять переважно 3 вузького підходу до розуміння державного управління як об'єкта реформування. Адже реформа державного управління визначається як здійснення цілеспрямованих перетворень, перебудови, удосконалення правового регулювання, результатом яких $є$ поступове формування нової системи державного управління або поява у діючій системі нових якостей, рис або суттєвих ознак. Проте, побудова науково обгрунтованої концепції розвитку державного управління в Україні відповідно до європейських традицій демократичного врядування потребує систематизації сучасних вітчизняних наукових розробок науки управління.

При цьому серед напрямів дослідження впровадження зарубіжного досвіду адміністративного регулювання останнім часом детерміновано достатньо сталий комплекс підходів наукового аналізу. По-перше, визначальне місце займає економіко-правовий підхід, реалізація принципу економічної доцільності, за якого правове регулювання виступає вторинним елементом, який забезпечує раціоналізацію економічних відносин, закріплення суто юридичного принципу недискримінації в контексті впливу економічних факторів (від створення зони вільної торгівлі до економіко-валютного союзу), посту- 
пово доповнюючись соціо-економічним контентом адміністративного регулювання.

По-друге, конституювання в межах сучасних наддержавних інтеграційних процесів норм комунітарного права призвело до формування інституціонально-правового підходу, що закріпив актуальність саме адаптаційної складової впровадження зарубіжного досвіду, оскільки недоцільно фокусувати увагу лише на особливостях правового механізму окремої європейської країни, адже на даний час норми права ЄC та Ради Європи визначають сутність як конституційного процесу в країнах-членах, так і особливості правового регулювання. По-третє, диверсифікація сфер співробітництва, поглиблення взаємозалежності країн-членів ЄС та країн, що закріпили політичний курс на набуття членства, актуалізують системний підхід до дослідження європейського інтеграційного процесу. По-четверте, розвиток наддержавного інтеграційного процесу в інституціональній, політичній і правовій сферах у будь-якому випадку призводять до якісного переосмислення сутності правового регулювання, реформування форм i методів управління у сфері міждержавних відносин. По-п'яте, зміни у функціях національних структур управління, перенесення центру прийняття рішень до інституцій наднаціонального рівня призвело до посилення неофункціонального підходу в методології правового регулювання, напрацюванні особливих правових конструкцій, що дозволяють оперативно вносити зміни у національні норми і стандарти публічного управління. I, по-шосте, формування спільних політик, уніфікація економічних механізмів, гармонізація правових систем потребували запровадження напряму дослідження інтеграційного процесу, що виходить з принципу федералізму, його юридичного змісту. Крім того, малодослідженою виявилась політико-правова сфера наддержавного інтеграційного процесу, система принципів формування i подальшого розвитку регіональних інтеграційних об'єднань та їх правових систем. На часі - напрацювання методології дослідження конституювання інтеграційного процесу як комплексу зовнішніх факторів впливу на суспільні відносини, результатом якого виступає діяльність інституцій управління наднаціонального рівня згідно з принципами, що визначені у договорах ЄС.

Таким чином, в Україні, що перебуває в процесі суспільної трансформації, існує потреба реформування не тільки адміністративної 
системи, а й усієї системи публічного управління в широкому розумінні. Сучасний стан реформування публічної адміністрації з позитивної сторони характеризується тим, що в Україні сформовано більшість інститутів публічної адміністрації, в тому числі, органи виконавчої влади та органи місцевого самоврядування, запроваджено державну службу та службу в органах місцевого самоврядування, створено нову правову базу, що регламентує державне управління та місцеве самоврядування. Водночас, не вирішеними виявились питання адміністративно-правового регулювання відносин органів влади різного рівня, дублювання і водночас, суперечність правових норм, що регулюють діяльність суб'єктів управління.

Зарубіжний досвід правового регулювання суспільних відносин свідчить, що у процесі адміністративного реформування виникає потреба вирішити такі завдання: 1) необхідність і надалі формувати високоефективну організацію виконавчої влади як на центральному, так і на регіональному (субрегіональному) рівнях управління; 2) необхідність формувати сучасну дієву систему місцевого самоврядування в контексті новел національного законодавства та зарубіжного досвіду муніципальної реформи; 3) необхідність запровадження нормативних гарантій раціонального функціонування органів влади щодо забезпечення та реалізації прав і свобод громадян, надання публічних послуг; 4) запровадження раціонального адміністративно-територіального устрою; удосконалення нормативно-правового забезпечення здійснення адміністративного реформування. При цьому аналіз напрямів трансформації державного управління на рівні національної держави у сучасному демократичному контексті розвитку, змін ролі держави в системі взаємовідносин «держава суспільство - людина» дозволяє визначити сучасне публічне управління як вплив держави на стан і розвиток суспільних відносин, поведінку та діяльність особи з метою досягнення цілей і реалізацію функцій держави через діяльність органів влади з урахуванням цілей і завдань всіх суб'єктів публічного управління. Важливим завданням реформування організаційно-правових засад державного управління $\epsilon$ приведення системи влади в Україні у відповідність до світових (європейських) стандартів суспільного управління, 3 урахуванням національних інтересів і процесів структурування наднаціональних систем управління. 
У контексті загальноєвропейських тенденцій адміністративного реформування проблема ефективності державного управління як результату раціонального взаємовпливу політичних та адміністративних аспектів зберігає свою актуальність через поєднання проблемних і малодосліджених сфер адміністративного реформування. По-перше, трансформація системи органів державної влади в контексті принципів адміністративного реформування інститутів $Є С$ та країн-членів $Є С$ (для України - відповідно до Угоди про асоціацію з СС [4]). По-друге, формування нової регіональної політики України, децентралізації управлінських відносин та розвитку механізмів делегованого управління на основі інституціональних змін в системі місцевого самоврядування. По-четверте, європейський вектор розвитку України через запровадження європейських принципів публічного адміністрування.

Аналіз зарубіжного досвіду адміністративного реформування дозволяє дійти висновку, що на етапі впровадження реформ система та підсистеми органів виконавчої влади мають відповідні організаційні структури, які відображають взаємозв'язки між окремими ланками системи і підсистем, субординацію по вертикалі та горизонталі, стосунки 3 вищими органами, підпорядкованими і підконтрольними об'єктами. Оптимальність організаційних структур цієї системи є одним із чинників підвищення ефективності виконавчої влади. Між цими рівнями передбачено субординаційні відносини, й відповідно, системі місцевих органів державної виконавчої влади властиві такі ознаки як: сукупність взаємопов'язаних, тісно взаємодіючих елементів, відносно самостійних за функціональним принципом; внутрішня організованість системи, що перетворює іiі в єдине цілісне явище зі спільною метою.

\section{3. Правовий зміст формування про-европейської моделі правового регулювання в системі публічного управління}

Практика демократизації та різні форми політичної участі населення в суспільному житті європейських країн свідчить, що в умовах зростання багатогранності напрямів діяльності суспільства, його диференціації та індивідуалізації в усіх сферах суспільного життя, будьякий державний апарат настільки віддалений від інтересів індивіда, що не спроможний враховувати місцеві особливості та інші специфічні умови життя громад. Тому цілком логічною є теза, що для більш ефек- 
тивного управління регіонами в країні має зростати роль регіонального і місцевого самоврядування, громадських організацій, які є більш наближеними до інтересів громад і регіонів. У контексті зарубіжного досвіду адміністративного реформування варто зазначити, що новий вимір реформування закладено у сутність сучасного трансформаційного процесу в Україні, зокрема, це стосується децентралізації влади як процесу передання значних повноважень та бюджетних ресурсів від органів виконавчої влади до органів місцевого самоврядування. Саме на основі зарубіжного досвіду формування напрямів місцевого та регіонального розвитку в Україні фактично змінено «ідеологічну» основу публічного адміністрування, адже реформа публічної влади має на сьогодні не латентний характер, а характеризується системним характером, будується на основі принципів сучасного управління (в межах інтегрованих систем публічного управління), і сприймається населенням як сучасний політико-адміністративний тренд.

Саме тому набуває важливого значення розробка сучасної концепції реформування державного управління, що базується на детермінації закономірностей розвитку Української держави в умовах реалізації положень Угоди про асоціацію з СС. Це, по-перше, традиції адміністрування в умовах розвитку національних систем публічного управління країн Свропи. По-друге, закономірності розвитку національних правових механізмів публічного адміністрування. По-третє, особливості виникнення і становлення національної системи публічного управління в Україні. Серед головних проблем, що уповільнюють проведення адміністративної реформи, виступає недостатнє нормативно-правове забезпечення, що обумовлює дискретність реалізації адміністративної реформи, певну дихотомію завдань реформи, засобів реалізації та кінцевого результату. Подолати такі проблеми, мінімізувати негативні прояви у процесі реформ можливо саме на основі раціонального запровадження європейського (зарубіжного) досвіду реформ.

Науковий аналіз політико-правових передумов, історичних етапів та самого феномену європейської інтеграції [5] дозволив охарактеризувати процес впровадження європейського (зарубіжного) досвіду адміністративно-правового регулювання як процес, за допомогою якого окремі країни надають частину своїх суверенних прав на користь утворюваної і єдиної для них усіх інституціональної структури з тим, 
щоб забезпечити врахування і реалізацію спільних інтересів. Це, по-перше, фундаментальні умови: бути європейською державою, мати спроможність і прагнення виконувати основні задачі цієї організації; по-друге, організація вільних виборів: у країні повинні бути демократичні, вільні, із таємним голосуванням і справедливі національні загальні вибори; по-третє, захист прав людини й основних свобод: держава, що визначає себе як європейська, повинна бути готова підписати і ратифікувати Конвенцію прав людини та основоположних свобод Ради Європи, а також інші документи, підписані і ратифіковані всіма членами конвенції; по-четверте, демократичність політичної і конституційної системи: досліджуються положення конституції про заснування демократичних інститутів, закон про вибори, положення щодо демократії на місцевому рівні, участь жінок в інститутах влади, свобода асоціацій, свобода профспілок, свобода преси і засобів масової інформації; по-п'яте, верховенство закону: досліджуються система захисту прав людини, зокрема, права національних меншостей, юридична система.

Саме тому доцільно з позицій аналізу конституційно-правових засад реформування державного управління в умовах євроінтеграційних процесів визначити етапи становлення, проблеми, структурні характеристики та тенденції організаційного розвитку національних систем управління в умовах сучасних євроінтеграційних процесів, встановити сталі динамічні тенденції розвитку національної держави та трансформації державного управління у такому процесі. При цьому слід врахувати напрацювання науки державного управління, юридичної, економічної та політичної наук задля системного оновлення демократичної концепції державного управління, адаптацію такої концепції до умов перехідного суспільства. За таких умов сучасна концепція модернізації може бути презентована суспільству як програма 3 довгостроковими пріоритетами, та може бути використана в якості теоретичної моделі при розробці нового та уточненні положень чинного національного законодавства у сфері державного управління та державної служби. На таких засадах розкриваються у новому аспекті особливості становлення та організаційно-правові засади управлінської діяльності в складних адміністративних системах, отримує самостійну наукову концепцію методологія адміністративно-правових засобів забезпечення прав і свобод громадян в умовах наддержавних інтеграційних 
процесів, оптимізується система класифікаційних ознак гармонізації міжнародного та національного законодавства щодо здійснення управлінської діяльності; обгрунтовується доцільність застосування методології системного аналізу до трансформаційних процесів в державно-управлінській діяльності за окремим науковим напрямом. Отже, нагальність системного дослідження організаційно-правових засад трансформації державного управління в контексті євроінтеграційних процесів визначається важливістю вирішення проблеми раціоналізації державно-управлінських відносин у сучасних умовах розвитку міждержавних зв'язків, міжнародної економічної інтеграції, глобалізації процесів суспільного управління.

У таких умовах набуває важливого значення розробка сучасної парадигми реформування державного управління, що базується на детермінації закономірностей розвитку національної держави в умовах євроінтеграційних процесів. Це, по-перше, закономірності розвитку національних систем публічного управління країн Європи. По-друге, закономірності розвитку національних систем публічного управління країн пострадянського простору. По-третє, закономірності розвитку національної системи публічного управління в Україні.

Системний аналіз напрямів трансформації державного управління на рівні національної держави у сучасному демократичному контексті розвитку національної держави, змін ролі національної держави у міжнародних відносинах дозволяє визначити сучасне державне управління як вплив держави на стан і розвиток суспільних відносин, поведінку та діяльність особи з метою досягнення цілей і реалізацію функцій держави через діяльність органів влади з урахуванням впливу наднаціональних чинників. Важливим завданням реформування організаційно-правових засад державного управління $є$ приведення системи влади в Україні у відповідність до світових (європейських) стандартів суспільного управління, з урахуванням національних інтересів і процесів структурування наднаціональних систем управління.

Саме тому характерною ознакою реформування державного управління на сучасному етапі державотворення в межах складних адміністративних систем є вплив зовнішньополітичних факторів, наднаціональне спрямування трансформації державного управління, розвиток принципово нового типу управління - делегованого управління. Водночас, напрацювання концептуальної основи раціоналізації суспільних 
відносин, що складаються у сферах державного управління, впливають на процеси суспільного та державного життя, а також безпосередньо пов'язані зі здійсненням органами виконавчої влади та їх посадовими особами адміністративно-правової діяльності із застосуванням інноваційних форм і методів, потребує самостійного дослідження феномену складних адміністративних систем в умовах інтеграційних процесів.

У цьому зв'язку слід підкреслити, що певна універсальність регулятивних механізмів у системі державного управління призводить до узагальненості державно-управлінських рішень у суспільно-політичній сфері на центральному рівні та зниженні ефективності управлінських рішень на регіональному та місцевому рівнях. У той самий час, переважна більшість політичних партій України функціонують лише на національному рівні, за практичної відсутності (або формальній наявності) регіональних структур, що негативно впливає на можливість загальнодержавного діалогу, адаптованого до регіональних проблем. За таких умов, у період реформування політичної системи України виникли дві сторони співвідношення «політика - влада» як прояву дихотомії політичної влади. По-перше, надмірна політизація владних відносин, зведення політики над владою, домінування політичних факторів у всіх сферах управління. По-друге, наукова проблема заперечення політичного у владі, зведення влади до економічно-господарських функцій. Такий стан речей пояснюється несистемним усвідомленням ролі державного управління у розвитку суспільних відносин. Таким чином, управління як особливий вид діяльності, що виконує роль організації та координації суспільних відносин, втрачає можливість до раціоналізації, набуває характеру «консервативної сталості».

Перед системою влади в Україні у процесі трансформації постали принципово нові завдання. Перш за все, важливо у процесі реформування на основі практики міжнародного менеджменту розробити програмні засади удосконалення механізмів інтеграційної політики України та визначити шляхи їх впровадження в практику формування та раціоналізації управлінських механізмів країни. Так само, у процесі реформування необхідно на рівні державних цільових програм удосконалити правові засади державної політики в умовах участі України в наддержавних інтеграційних процесах, й задля цього необхідно уточнити методологічні орієнтири і критерії раціональної державно-управлінської діяльності. 
Варто наголосити у контексті імплементації зарубіжного досвіду адміністративного реформування, що у межах функціонування $\mathrm{CC}$ Європейський адміністративний простір (ЄАП) виступає у вигляді відкритої інтегрованої системи публічного управління на наднаціональному рівні, яка: грунтується на принципах європейського права, функціонально, структурно і предметно базується на ключових принципах договорів про Європейський Союз, закріплена нормами національного законодавства країн-членів, включає правові засади співробітництва з європейськими країнами - не членами СС в межах дво- та багатосторонніх угод, реалізує програмні положення відносин з групами держав в межах Європейського континенту, формує принципи регіонального, транскордонного та міждержавного співробітництва, регулює суспільні відносини на різних рівнях управління, i, водночас, між органами управління і громадянами, забезпечує дотримання норм права у різних сферах соціального управління, перш за все, щодо дотримання прав і свобод громадян, i інтегрально пов'язує економічні, політичні, соціальні та гуманітарні аспекти управління в складних адміністративних системах. Як і будь-яка адміністративна система, САП формалізований через низку публічно-правових норм, що напрацьовані у процесі формування на теренах Європи сучасних національних держав та наднаціональних утворень.

Сучасні дослідження інститутів публічного управління у наукових працях практично завжди пов'язувалися 3 одночасним розглядом питань, що стосувалися адміністративно-правових форм публічно-управлінської діяльності [6]. Це пояснюється тим, що публічне управління має універсальний характер, знаходить свій прояв у суспільному житті через властиві лише у публічно-правовому контексті процедури. Саме тому вважаємо, що публічне управління як система суспільних відносин у контексті формування європейського адміністративного простору передбачає:

- застосування нової методології аналізу організації державно-управлінської діяльності щодо реалізації інтеграційної політики України та визначення критеріїв і показників ефективності дій владних структур на центральному та регіональному рівні управління;

- встановлення правових засад інституціоналізації механізмів державного управління $з$ огляду на їх важливість 3 точки зору забезпечення прав і свобод громадян національних держав; 


\section{Theoretical and methodological basis of implementation of the foreign...}

- виокремлення сутності, правової природи та принципів регулювання процесів управління, іманентних їм критеріїв класифікації,визначається принципами європейського адміністрування на рівні наднаціональних структур.

\section{4. Висновки}

Актуальність наукового аналізу зарубіжного досвіду адміністративного реформування зумовлена комплексом факторів. До найголовніших 3 них належить: по-перше, той факт, що на етапі суспільно-політичних трансформацій в Україні відсутня достатньо усталена система суспільно-значимих пріоритетів адміністративного реформування, що сприймаються суспільством як визначальний напрям розвитку держави. При цьому концептуальні засади саме адміністративної реформи не сформовані у адміністративно-політичному й суспільному сприйнятті як цілісна програма національного розвитку, а виступають частиною загальної стратегї національних реформ. Саме тому в контексті загальноєвропейського досвіду адміністративного реформування стала очевидною загальна тенденція до посилення ролі держави як суб'єкта політичної влади та одночасного звуження їі ролі як безпосереднього суб'єкта в системі локального і регіонального управління. Такий стан певною мірою пояснюється політичними факторами, i разом $з$ тим, актуалізує проблему нормативного закріплення положень адміністративного реформування.

Демократизація публічної адміністрації виступає однією 3 передумов інтеграції України до європейських і світових політичних та економічних структур, зокрема і до ЄС. Йдеться про реформування, насамперед, центрального апарату, що займається державним управлінням. 3 позицій напрацювання методології дослідження зазначимо, що зазвичай, у вітчизняному державному управлінні використовується термінологія, що перейшла ще з радянської адміністративно-правової доктрини; добре відомий усім термін «державне управління» є перекладом поняття «публічна адміністрація», хоча при детальнішому зіставленні цих категорій видно, що вони не є тотожними (друге $є$ значно ширшим). I, взагалі, що стосується пострадянської адміністративно-правової доктрини, то, як зазначає більшість науковців, вона відображає й обслуговує так звану «державоцентристську» ідеологію, при якій державницькі інтереси, тобто «благо держави», превалюють 
над інтересами людини i, зрештою, всього суспільства. На противагу цьому, в основу нової адміністративно-правової доктрини має бути покладена протилежна - «людиноцентристська» - ідеологія, згідно 3 якою держава має «служити» інтересам громадян шляхом всебічного забезпечення пріоритету їх прав, свобод та інтересів у сфері діяльності органів публічної адміністрації: органів виконавчої влади та органів місцевого самоврядування.

Уточнено зміст, сутність та правову природу сучасної парадигми публічного управління. Власне, процес адміністративного регулювання в ЄС побудований на загальновизнаних правилах і процедурах суспільного управління, характеризується відсутністю будь-якої дискримінації, довів власну ефективність у контексті сучасних глобалізаційних процесів. Аналіз законодавства європейських країн, міжнародно-правових документів, зарубіжного, зокрема європейського, управлінського досвіду, дає підстави стверджувати, що власна, національна система публічного управління в Україні має бути визначена через дотримання правил і процедур демократичного врядування, формалізованих у процесі європейської інтеграції та розкритих у контексті поняття «європейська ідентичність» як у правових актах $С \mathrm{C}$, так і в двосторонньому форматі відносин «Україна - ЄС». Саме на засадах історико-теоретичного аналізу сучасних умов трансформації суспільних відносин в Україні варто базувати процес імплементації зарубіжного досвіду

\section{Список літератури:}

1. Про Стратегію сталого розвитку «Україна-2020»: Указ Президента України від 12 січня 2015 року № 5/2015: Режим доступу: http://www.president. gov.ua/documents/18688.html).

2. Войтович Р. Регіоналізація як обернена форма глобалізації та ії вплив на систему державного управління / Р. Войтович // Вісн. НАДУ. - 2007. № 2. - С. 15-25.

3. Войтович Р. В. Вплив глобалізації на систему державного управління: дис. ... д-ра наук з держ. упр.: 25.00.02 / Войтович Р. В. ; Нац. акад. держ. упр. при Президентові України. - К., 2009. - 403 с.

4. Виконання Угоди про асоціацію між Україною та ЄС [Електронний pecypc] / Кабінет Міністрів України // Режим доступу: http://www.kmu.gov. ua/control/uk/publish/article\%3fart_id=247749544\&cat_id=247749488 - Назва 3 екрану.

5. Wallace H. EU Enlargement: A Neglected Subject / H. Wallace // Cowles M., Smith M. The State of the European Union: Risks, Reform, Resistance and Revival. - Oxford : Oxford University Press, 2000. - Vol. 5. - P. 149-164. 
6. Olechowskij A. Four Premises for the Polish Strategy in the European Union. / A. Olechowskij // The Polish Foreign Affairs Digest. - 2003. - Vol. 3. N. 4(9). - P. 2335.

\section{References:}

1. Pro Strategiyu stalogo rozvytku "Ukrayina-2020»: Ukaz Prezydenta Ukrayiny vid 12 sichnya 2015 roku № 5/2015: Rezhym dostupu: http://www. president.gov.ua/documents/18688.html).

2. Vojtovych R. Regionalizaciya yak obernena forma globalizaciyi ta yiyi vplyv na systemu derzhavnogo upravlinnya / R. Vojtovych // Visn. NADU. 2007. - № 2. - P. 15-25.

3. Vojtovych R. V. Vplyv globalizaciyi na systemu derzhavnogo upravlinnya: dys. ... d-ra nauk z derzh. upr.: 25.00.02 / Vojtovych R. V. ; Nacz. akad. derzh. upr. pry Prezydentovi Ukrayiny`. - K., 2009. - 403 p.

4. Vykonannya Ugody` pro asociaciyu mizh Ukrayinoyu ta ES [Elektronnyj resurs] / Kabinet Ministriv Ukrayiny // Rezhym dostupu: http://www.kmu.gov.ua/ control/uk/publish/article\%3fart_id=247749544\&cat_id=247749488 - Nazva Z ekranu.

5. Wallace H. EU Enlargement: A Neglected Subject / H. Wallace // Cowles M., Smith M. The State of the European Union: Risks, Reform, Resistance and Revival. - Oxford : Oxford University Press, 2000. - Vol. 5. - P. 149-164.

6. Olechowskij A. Four Premises for the Polish Strategy in the European Union. / A. Olechowskij // The Polish Foreign Affairs Digest. - 2003. - Vol. 3. No. 4(9). - P. 23-35. 


\section{THE REFORM OF THE LOCAL SELF-GOVERNMENT \\ OF THE CZECH REPUBLIC AND SLOVENIA. EXPERIENCE FOR UKRAINE}

\section{Murzina Tetiana ${ }^{1}$ \\ Pakhomova Tetiana ${ }^{2}$}

DOI: http://dx.doi.org/10.30525/978-9934-571-29-9_8

Abstract. The analysis of the main changes in the system of local self-government of Slovenia and the Czech Republic (in legislation and structure): the traditions of local self-government and its national peculiarities have been studied, the normative-legal base of local self-government has been analyzed in terms of the principle of subsidiarity in Slovenia and the Czech Republic at the settlement level (village, community) in accordance with the legislation of the European Union.

The reasons, conditions and consequences of local self-government reform are considered, attention is focused on changes in the territorial structure, distribution of powers between central and local authorities, legislative regulation, etc. The goals and objectives of the research are determined. Taking into account the similarity of the historical development of these countries with Ukraine, an attempt was made to analyze the process of solving problems that arose in them during the reform of the system of local self-government. The analysis of the current legislation on local self-government in the Czech Republic and Slovenia makes it possible to identify the strengths and weaknesses of the country and make appropriate conclusions in order to avoid such mistakes in the future.

Modern understanding of the legal provision of public administration involves the functioning of a universal organizational and legal mechanism for identifying, coordinating and implementing social needs and interests based on the use of various legal means, the formation of subjective rights

\footnotetext{
${ }^{1}$ Postgraduate Student of the Department of Regional Policy and Public Administration, Odessa Regional Institute for Public Administration of the National Academy for Public Administration under the President of Ukraine

${ }^{2}$ Head of the Department of Regional Policy and Public Administration,

Odessa Regional Institute for Public Administration

of the National Academy for Public Administration under the President of Ukraine
} 
and obligations of participants in social processes, the transfer of their relationships and relationships in specific legal relationship.

The experience of foreign countries suggests the existence of several approaches to the organization of self-government - depending on its relationship with the state authorities and the scope of its powers

Despite the large number of works on the issue of reforming local self-government, the current state of the system of local self-government in Ukraine and attempts to reform it have led to the search for new approaches to the territorial organization of power.

At the same time, the experience of European countries, in particular the former countries of the "socialist camp", which has also gone through the path of not only social change, but even the collapse of the countries, remains inadequately studied in the science of state administration. In this case, taking into account their experience and the ability to make correct conclusions in time becomes especially valuable for Ukraine.

This article describes the peculiarities of the processes of decentralization of power in the Czech Republic and Slovenia, in particular the financial independence of local self-government, a peculiar system of representation of the state at the lower level of government, the role of municipal institutions, etc. The main problems faced by Ukraine in the initiated reform of the decentralization of power are highlighted, and further directions of development of this process are outlined taking into account the experience of the mentioned countries.

\section{Introduction}

In the modern European civilization tradition, it is considered that local self-government is one of the main foundations of any democratic system. This thesis is enshrined in the European Charter of Local Self-Government, and Ukraine is included among the signatories of it.

Since the second half of the 20th century, in the states of Eastern and Southern Europe, at least twice, all the spheres of public life have been changed, including the reforms in the field of state building, in particular in the system of public authorities. An important place among them took the reorganization of local power, which was primarily connected with the rejection of the institution of local self-government in the so-called socialist period, and then with the revival of this institution after the change of political regimes in former countries of "people's democracy" at the end of the XX century. 
Local self-government and local administration in the post-socialist states of Eastern and Southern Europe are inextricably linked with the process of establishing of democratic regimes and, as a consequence, the formation of a new legislative framework that governs the activities of municipal institutions.

Within the framework of the European integration course, the reform of the basic organization of the population, which has entered the newest history of Ukraine as decentralization, is one of the most significant. It is clear that the existing model inherited from the Soviet era has largely lost its functionality. And since overcoming the lag in the development of democratic institutions of Ukraine is necessary to be done in the shortest possible time, the experience of more successful countries seems simply indispensable.

Thus, the study of the problem of the transition of Eastern European countries from the centralized system of public administration to local self-government becomes of special interest and urgency.

The purpose of the article is to conduct a theoretical and legal analysis of a complex of problems associated with the transition from a centralized system of public administration to the local level until the formation of local self-government and local administration in the states of Eastern and Southern Europe, as well as (taking into account the theoretical and practical results that already exist) detection and analysis of the features of the models of local self-government in the countries under study.

\section{Presentation of the main material}

In all democratic states, the presence of local authorities, endowed with a certain autonomy, is the realization of the principle of separation of powers in practice and, importantly, one of the main signs of pluralism in society. Destruction of local self-government is seen as a symptom of totalitarianism. In other words, the less power on the ground - the less democracy and the higher is the level of authoritarianism. (It was no accident that in the 1930s in Germany local self-government bodies became one of the first victims of the Nazi regime).

It should be noted that for the system of local self-government in the modern period of development, unlike businesses, the state of imbalance is provoked primarily by the processes occurring in the environment. To understand the behavior of such system is necessary to possess information about the 
composition "of the original system and the environment", the components of which are linked. As you know, any system evolving through the innovations (in our case, the system of local self-government) has the sufficient time and space in which its functioning and development occurs.

The systems, that are being developed, are characterized by a combination of stability and instability of the structure, because of the two stationary stable states of the system sustainable at any given time there can be the only one. For the system of local self-government (as for an adaptive social system) information characteristics that reflect semantic and pragmatic aspects of information become important. The principle of increasing of the adaptability of the local government system to dynamic external environment involves the implementation of such innovations that provide an increased adaptability of the system.

The European Charter of Local Self-Government was adopted in 1985 by the Congress of Local and Regional Authorities of the Council of Europe and is the most important multilateral document defining the fundamental principles of the functioning of local self-government bodies. The charter was signed by 47 states of Europe, including Ukraine.

In accordance with the European Charter, local self-government is based on three basic principles:

- the right to local self-government;

- power of general competence;

- the principle of subsidiarity [2, p. 295].

The right to local self-government is the consolidation this right at the level of laws and constitutions.

Power of general competence or general authority has the ability for local governments to take any actions, except those that are prohibited by national law.

In most Western European countries, local authorities have general competence, that is, the right to take any action in the interests of the local community, which is not specifically for them.

The principle of subsidiarity means that the competence in one or another area of activity, if possible, belongs to the lowest level of management that is as close as possible to the people. In other words, what can be solved by a village or settlement should not be decided at the district level. What can be solved at the district level should not be decided at the region level. And, accordingly, what can be solved at the level of the region should 
not be decided at the state level. Independent Ukraine inherited the Soviet-era management principles when central authorities attempted to include as many issues as possible in their area of competence, leaving to the communities only meaningless ones.

One of the directions of the reforms of the system of local self-government in Ukraine is decentralization. Decentralization is considered as the transfer of significant powers and budgets from the executive authorities to the local authorities. Decentralization is one of the types of the reforms that conduce to the progressive development of the country. Poland, Slovakia, Lithuania, Latvia, Estonia, Scandinavian countries - all of them went through such reform that gave impulse to the economy, social development of these countries.

The efficiency of the reforms of local self-government is closely linked with the adequacy of their scientific support. This increases the results of organic interaction between bodies of local self-governments and public institutions, business structures, scientific and educational institutions and others. The importance and necessity of the research of the problem of reforming the system of local self-government in the context of the innovation discourse is due to that this scientific problem has not found its system reflection in national and foreign scientific literature, has not become the object of close attention from the local authorities, politicians and the public. At the same time, it is clear that the qualitative analysis of the current position of the reforming of local self-government on the basis of innovating development will contribute to the effectiveness of the practical implementation of local self-government reform in Ukraine.

However, despite the importance of the development of scientific approaches to the processes of the reforming of the system of local self-government, a number of issues, associated with the analysis of the processes of reforms in the context of the innovative development, remains outside the attention of the scientists.

Let's consider the experience of some post-socialist republics.

\section{The Republic of Slovenia}

In accordance with the Slovenian constitution, local self-government is implemented in communities and other local organizations and associations.

The Slovenian Constitution contains corresponding norms both in the sections of general norms and in the sections of organization of local 
self-government (Slovenian Constitution of 23.12.1991 (Part 1. "Introduction" and Part V. "Self-government"). Slovenes carry out local self-government with the help of municipalities and others local self-government organizations (Article 138 of the Constitution of the Republic of Slovenia).

Communities form the main unit of local self-government, covering from one to several settlements. The territory communities are formed on the basis of referendum results that are held among residents of a particular locality. The consultative referendum on June 22, 2008 was devoted to the community association in the region [5].

There are 210 communities in the country, 11 of which have urban status. Within the limits of its competence the community independently decides on issues of local importance. Communities are self-financing at the expense of their own sources of income, and those who lack the funds receive additional financial subsidies from the state budget.

The highest governing body of the community is the Council, whose members are elected by direct vote. The head (zhupan) - the head of administration, is also elected by the people and controls the implementation of the decisions taken by the Council.

Communities were formed in Slovenia on the operational decisions, if the people in a certain area decided (and the authorities developed a procedure for each decision) to organize self-government, a local community or a municipality, the parliament, for the most part, adopted such decisions and passed the necessary law. For the formation of the communities, such criteria as the level of housing stock, the number of people, schools, kindergartens, some other existing institutions necessary for the functioning of the local community, were put forward, but there are many exceptions. Thus, in mountainous regions there are communities with a population of 500 people, not 5000 . That is, they are much smaller. The key criterion was the decision of the people who lived in the area.

Major statistical data:

The area of the country is 20,256 square kilometers; The population is 1,994,084 (as of December 1, 1992).

The Slovenes exercise authority and functions of local self-government through the self-governing municipalities and other local government organizations. A municipality may include one community or several. The municipality is founded on the basis of the law as a result of a positive vote in the referendum. A town or a city can get the status of a city municipality. 
The list of duties and functions of the municipality includes such local affairs, which concern only the population of this municipality.

The state may, by legislative procedure, impose certain duties and functions that fall within its jurisdiction over the municipalities. The state supervises the proper and effective fulfillment of all the duties and functions transferred to its municipalities. The supervision of the implementation of local government bodies is carried out by the specially created state bodies.

The system of local self-government is one of the most important norms of the Slovenian Constitution, which introduced new laws in this area. Shortly after the adoption of the Constitution in December 1991, there was a need to reform the structure of local self-government.

The current reform of local self-government has several changes on its aim. First of all, we need the territorial redistribution of communities. Today, the territory of the communities is large. Reducing communities is necessary in order to better meet the needs of citizens. According to the Constitution, territorial changes in the communities are adopted by referendum. Another reform that affects the system of local government is the reform of the structure of the state administration at the subregional level. The current structure of the state administration does not include general sub-government bodies for the performance of government functions at the local level. The reason for this decision is that today almost all tasks and competences of the state administration are concentrated at the local level in the administrative systems of local authorities. The proposed reform stems from the idea of a clear division of functions between the state administration and local governments.

There is no general government territorial division in Slovenia. There are only ministries that cover the entire territory of Slovenia and can carry out a variety of activities through their territorial services. The ministries set up such services where they must perform their respective tasks at the local level. Most government functions are carried out by communities and their administrative departments. Each ministry has its own representation at the local level, and such representations form a peculiar, partly hierarchical administrative structure.

The municipality may, according to the law, own, purchase and possess all types of property, establish public and other companies, and manage them, as well as determine their budget within the framework of the public finance system. 
The municipality's responsibilities include air, land and water protection, noise protection, waste collection and recycling.

Other responsibilities and functions:

- promotion of sports development;

- local events monitoring;

- organization of municipal services of the local police.

The municipality guarantees the fulfillment of local public tasks, defined by itself, as well as public tasks determined by law. Public services are governed by the laws regulating the supply and distribution of energy, transport and communication, water management with the enterprises concerned, and the protection of the environment.

Public authorities supervise the legality of actions of municipal authorities. State supervision of the work of local community bodies is exercised by the government of those ministries. The mayor must immediately submit to the government or the relevant ministry the decrees by which the municipality will regulate cases transferred to it from under state jurisdiction. The government or the ministry may suspend the enforcement of the decree that they consider to be illegal, as well as pass it on to the Constitutional Court.

Mandatory forms of interaction between local governments do not exist. But according to the Law on Local Self-Government, local communities can cooperate. Self-governing local community is a public entity.

Today, according to many experts, self-government is at a satisfactory level, since this institution has been functioning effectively in Slovenia for about a century.

But we see that Slovenia is not the best example here; it is still a very centralized state, like Ukraine.

\section{The local government of the Czech Republic}

The constitutional and legal foundations of the local self-government of the Czech Republic are laid down in Chap. 7 of the Constitution of the "Local Self-Government" and the laws "On the bribery (protest proceedings)" - the municipalities and "On the provinces (district proceedings)" the districts [10, p. 100].

According to Art. 8 of the Basic Law of the Czech Republic the principle of the local self-government of territorial units is guaranteed. This constitutional provision is one of the main principles of state-building in the Czech Republic [8]. 
The Czech Constitution, by establishing the scope of the right to local self-government, defined its basic principles:

- guarantee of the right to self-government (Article 101, paragraph 4).

- Self-government is an independent form of public authority with its own competence in the sphere of property, financial management, organization, rule-making (Article 101, point 1.2, Article 104 of the Constitution of the Czech Republic).

- The main carriers of the right to local self-government are the territorial communities of the citizens (Article 100, paragraph 1, Article 101 of the Constitution of the Czech Republic).

- The territorial basis of local self-government is the community (Article 99 of Article 100 of the Constitution of the Czech Republic).

- The presence of a representative body of local self-government is mandatory in the formation of the organizational structure of a specific municipal entity (Article 101, paragraph 1.2, Article 102, Article 104 of the Constitution of the Czech Republic) [8; 5, p. 176-177].

It is important to note that the Czech Constitution provides for the right to self-government as a right, and not the responsibility of the relevant municipal organizations. At the same time, according to Art. 101 of the Czech Constitution, the local self-government unit is characterized as "a public corporation that can own property and manage it according to its own budget." This concept is then elaborated in clause 2 of the ch. 2 of the Law "On the Circumcision" [8; 9].

The administrative-territorial reform in the Czech Republic was carried out in two stages and lasted for about 10 years. The first stage was aimed at developing the conceptual foundations for reform, in particular the preparation and approval of the Concept of Public Administration Reform.

First of all, the reform concerned the changes in the structure of the administrative-territorial division and the extension of the powers of local self-government bodies at the basic level. So, in 1990, the Czech Republic abandoned the three-level structure of the administrative-territorial system (municipality, district, region), introduced in 1960, and returned to a twolevel structure (municipality, province).

The liquidation of the regional committees has led to a sharp increase of the role of the central authorities and at the same time to reducing the effectiveness of public administration, depending on the size of the territory. The oblast was recognized as an entity that did not meet the traditions of 
self-government in the Czech Republic and was abolished, and its powers were transferred to the districts and communities. Accordingly, the order of formation and the volume of powers of the local self-government bodies of the basic level have changed. First of all, communities have the right to elect municipal authorities and to conduct local referendums, to form and to manage the budget, to provide their own socio-economic, cultural and communal needs.

At this stage in the Czech Republic there was a system of territorial division:- parliament (House of Deputies and Senate), central government (government and ministries);

- district departments (district administration);

- Municipal Governance and Municipal Council of Representatives.

In 1997, the Czech Parliament approved a law on the two-level structure of the administrative division of the country, the actual implementation of the administrative-territorial system of the country took place only in 2000 after the adoption of laws on elections to local self-government bodies, determination of their status, powers and relations with local and central authorities.

As a result of the transformation of the administrative-territorial system from January 1, 2000, 14 regions (instead of 8 before the reform) were created as higher territorial units of self-government. In addition, on May 16, 2001, amendments were made to the Constitutional Law of 1997 "On the Establishment of High Territorial Self-Government Units and on the Changes of the Constitutional Law of the Czech Republic No. 1/1993» regarding changes in the names of the four regions. Consequently, the Czech Republic abandoned the three-level structure and returned to a twolevel structure.

By the Law No. 347/1997 of the provisions of Art. 99 of the Constitution of the Czech Republic were redefined and affirmed that the country is divided into municipalities, which are the main territorial self-governing units, and the provinces that are the highest self-governing units. Thus, the 14 regions that were formed replaced 80 district administrations. As a result of the reform, 6,242 communities were formed, which according to the Constitution of the Czech Republic (Article 100) are constituent parts of the territories.

The municipality in the Czech Republic has always been regarded as the main element of self-government. In accordance with Article 1 of the 
Law "On Communities" of April 12, 2000, N6 128/2000, the municipality is the main territorial community of citizens, which forms a territorial unit that is bounded by the borders of the municipality. A municipality may acquire the status of a city if it has at least 3,000 inhabitants, and the chairman of the Chamber of Deputies will take such a decision. In addition, cities such as Kladno, Ceske Budejovice, Plzeň, Karlovy Vary, Usti nad Labem, Liberec, Hradec Krakow, Pardubice, Jiława, Brno, Zlín, Olomouc, Ostrava, Opava, Gavierow and Most received special status. The status of such cities (statutory) is determined by law and their charters. Management in the cities of Brno, Ostrava, Plzeň has its own peculiarities distinctive from other cities, in particular:

- the municipal authorities carry out, in addition to the powers of the municipal administration, in the respective territory, also the powers of the district administration, unless otherwise provided by law;

- the city manager appoints and dismisses the manager of the regional administration;

- in the event that the representative office is unable to meet within 6 months, the Ministry of Internal Affairs is entitled to dismiss it [9].

A municipality ruled by its elected representatives has, in full use of its capabilities, the duties and rights assigned to it, and also satisfies the needs of its citizens. Citizens, in their turn, have the right to exercise control over the activities of local self-government bodies, namely, the activities of the mayor and members of the Council.

Municipalities are the part of larger local government units and represent self-governing community of citizens governed by elected representatives of the population: the municipal council and the senior citizen. Members of the municipal council are elected by universal and equal election for 4 years. The condition for participation in the elections is the residence in the territory.

Local communities of the citizens can monitor local activities. Bodies of local self-government are independent, legal and economic entities. Bodies of local self-government have the right to decide on the following issues: to develop projects and approve municipal budgets, as well as reports on municipal activities; freely distribute funds among the relevant services in order to meet public needs; approve the composition of municipal enterprises and funds. Thus, it can be emphasized that the presence of a large number of small entities does not positively affect the implementation of the principles of effective local self-government. 
Municipalities can conduct administrative activities regardless of the state, which may interfere in the affairs of the territories only in case of violation of laws and only within the framework of legislative norms. Municipalities have the right to dispose of property and conduct economic affairs in accordance with their own budget (Article 101).

As a result, the administrative-territorial reform in the Czech Republic provided for the formation of a multi-level governance, inherent in the EU. This has enabled these countries to derive certain benefits from the EU structural policy and influence the process of implementing the EU's regional policy through the Committee of the Regions. But experience has shown that such municipalities are not capable of realizing self-government functions, since they do not have the appropriate material resources and the required number of specialists and officials. It is now clear that the decision-making process will be effective in combining small entities into large ones.

Municipalities provide for the solution of local issues independently within the framework of self-government or carry out delegated powers within the respective territories to the extent stipulated by special legislation. The spheres of self-activity of municipalities, which they carry out within certain territorial boundaries, include economic development, social security and cultural activities, environmental protection, as well as activities envisaged by special legislative acts [9; 1, p. 97].

At the local level there are 6242 municipalities.

The municipal councils include deputies elected by direct vote for a four-year period. The Council of Deputies elects members of the executive body - the Municipal Committee. Among them are the mayor and deputy mayors. This executive body forms the commission.

The mayor is elected by a council of its members for four years. He heads the Municipal Committee, Administration and Council. In municipalities where the Municipal Committee has fewer than 15 members, the executive power is represented only by the mayor.

Authority of the municipal council:

- municipal budget;

- local development;

- municipal police;

- water supply;

- agriculture; 
- primary education;

- housing;

- social assistance;

- urban planning.

The Regional Assembly consists of members elected by direct vote for a four-year term. This representative body controls the budget and subsidies that are provided to municipalities. He is also a subject of legislative initiative.

The executive body for the region's council is the Regional Committee, consisting of the president, vice-presidents and other members, who are elected for a four-year term. This committee assists at the level of regional governance and public services.

Authority for the region's council [10]:

- secondary education;

- roads;

- social assistance;

- environment protection;

- public transport;

- regional development;

- health care.

In the Czech Republic, as in most countries around, the contribution of own revenues to local budgets remained too small.

The rights of councils for establishing local taxes were not passed by law. In spite of this, associations of local authorities in many countries focused on ensuring the transfer of a fair share of national taxes to the local level. In the Czech Republic, municipalities receive 21 percent of the total personal income tax and corporate profit tax. The distribution is based on the population growth rate. This method of tax revenue distribution is fixed in the law (as in Slovakia) and does not depend on decisions regarding the State annual budget.

In the Czech Republic there is the Ministry of Regional Development, which was established in 1996. It has the task of ensuring that the policy of the Czech Republic is consistent with the policy of the European Union, which traditionally plays a significant role in the regions [4, p. 271].

The municipality's governing bodies are the municipalities (the highest self-governing body, which performs the most important powers in the area of self-government), the municipal council (executive body) and the municipal administration. 
Thus, local self-government in the Czech Republic is one of the main constitutional institutions that allows the population of self-governing territories, regardless of the state authorities, to resolve certain issues of local importance within the limits of their own and delegated competence, stipulated by the law of the republic.

An analysis of the Czech experience will allow Ukraine to avoid the standard political risks and negative consequences that may arise as a result of the imbalance between the forms of government and the failure to take into account the general trends in the establishment of democracy. At the same time, it will contribute to the borrowing of positive institutional changes, mechanisms for the implementation of the reform processes and the establishment of a functional civil society. It should also be taken into account that the reform of the local self-government system is a complex and long-term process, the effectiveness of which depends on the legislative provision of administrative reform and skilled administration.

In EU countries there are two-level (eg, municipality, district) or threelevel (village or parish, municipality, district) self-government model. In Ukraine, the situation is similar. There are three levels: village, town and city councils - district councils - regional councils. Plus, regional centers are also territorial communities.

To prove local self-government to the absolute, that is, to one level, does not seem expedient. The multi-level system, on the one hand, can bring power closer to specific citizens at the village or village level, and on the other hand, accumulate funds and staffing capacities at the district and oblast level (district, region) to provide more complex services to the population. It is clear that the rural community (or commune), especially in Ukraine, is not able to receive a significant amount of funds and attract high-quality specialists to implement complex infrastructure projects - the construction of a hospital, school, gas pipeline, etc.

\section{Conclusions}

After analyzing the current state of local self-government in such post-socialist countries as Slovenia and the Czech Republic, and after examining the latter, on the whole, positive conclusions, European experts, in particular representatives of the Congress of Local and Regional Authorities, we can state that the organization of local self-government in the Czech Republic meets the standards of the European Charter of Local Self-Government. 
Thus, foreign municipality knows various models and types of organization of local self-government. Differences in the construction of local self-government systems depend on many factors: the country's dominant political regime, the ideas of the organization of power and local governance, the state structure and the administrative-territorial division of the state, national traditions, etc. The analysis of the basic systems and models of local self-government, the characteristics of local governments of foreign countries allows us to borrow useful foreign experience for the modern Ukrainian reality, and also take into account the negative experience of the organization and functioning of the principles, functions and bodies of local self-government of the respective countries. Changes in the economy, politics and ideology of modern states call for the adaptation of existing systems of local self-government to new realities. In addition, the practice of municipality is constantly being improved, producing new models, forms, types of organization of local self-government. The process of reforming of local self-government is one of the most noticeable phenomena in the world community. Its general tendency is the development of self-governing principles and the decentralization of power, which simultaneously coincides with the statement of the growing inability of the state to resolve some of the issues of public life in centralized forms.

The achievement of the desired state of local self-government is impossible without the implementation of a number of legislative and institutional reforms. Such are the transformations concerning the administrative-territorial system, the election of local deputies, the formation of executive bodies of local self-government, the delegation of powers and control over their implementation, the collection of local taxes, the maintenance of unprofitable enterprises, etc. At the same time, the orientation of foreign experience in solving such problems and the fundamental values in the field of local self-government of the European Union countries should not be avoided.

The development of the system of local self-government through the reform can be considered as such that is ensured not only by external factors but also by internal mechanisms, as the development through the processes of self-organization. This development is primarily provided by the activity of the officials of local self-government. This happens in cases when, for example, an official, taking part in managerial decision-making, offers new and effective methods for their implementation. In this case, the official of local self-government is implementing an innovative type of behavior. In 
real conditions in the system of local self-government there are the processes of the development through the self-managed development and managed development.

The scientific literature on the management of innovations, deals with the problems of the development of the new qualitative approaches to the decision-making of innovative solutions, the creation of the strategic management systems. As for the historical perspective, it is necessary to point out that initially the problem of the development of systems have been studied in the connection with the problem of the development of enterprises, when developing the methodology of strategic management and planning. Ineffective functioning of enterprises in a dynamic, competitive environment that was associated with the inability to determine adequately the parameters of the environment and the immutability of functional structures of enterprises, was the beginning of the transition to the development and usage of methods of the strategic management.

Strategic planning includes the specific steps associated with the identification of the problems, strategic goals, the criterion of effectiveness of implementation of the strategy, and others. In this case, with the aim of expediting the system response on the external influence factors, some of the strategic powers, as a rule, should be referred to the heads of the main technological process (the managerial decision-making and service delivery). As you know, today advanced industrial corporations use flexible, organic structures to govern innovation processes. In the first stage of the innovation process (ideas, analysis and assessment, calculation of the budget) employees gather in informal, poorly regulated project teams (creative teams). And in the second stage (implementation of innovations) rigid, formalized organizational structures are used.

To improve the innovative climate in the system of local self-government, should be implemented the mechanisms of the innovation policy. It means that one of the directions of the development of the mechanisms of the management of the innovations (reforms) may be the creation of research groups on the development of policy of local self-government reform, the strategy of its development.

So, the main success factors for increasing the effectiveness of the development not only separate social institutions, but states, today, despite of the global crisis, become the paces of transition to the sustainable development and the usage of new knowledge in the system of local self-government, 
which includes the introduction of modern technologies and administrative methods, the development of modern competences of the officials of local self-government and so on.

It is necessary to open the way to a local initiative, to involve in the management of the affairs of their cities their inhabitants more actively - that is, to fill the real meaning of the concept of self-government. Local authorities, like the authorities of all other levels, should become open, transparent and understandable.

\section{References:}

1. Vidlakova O. (2001.) Polityko-administratyvni vidnosyny v Cheskii Respublitsi [Political-administrative relations in the Czech Republic] O. Vidlakov, Polityko-administratyvni vidnosyny: khto stoit u vlady? [Poditico-administrative relations: who is in power?] (ed). T. Verheine M., pp. 17-128.

2. Latsina K. (2000) Mistseve samovriaduvannia v Cheskii Respublitsi [Local Government in the Czech Republic], K. Latsina, Z. Vaidova, (Detsentralizatsiia: eksperymenty i reformy) [Decentralization: Experiments and Reforms] (ed) Tamasha M. Croat. - T.1. - Budapest, pp. 295-340.

3. Lemak V. (2003) Pravova reforma v Chekhii i Slovachchyni v umovakh postsotsialistychnoi modernizatsii: teoretychni i praktychni problemy [Legal reform in the Czech Republic and Slovakia in post-socialist modernization: theoretical and practical problems.] Dis ... doc. Jurid Science - K., pp. 414 - Mode of access: www.nbuv.gov.ua.

4. A.S. Prudnikov, L.A. Larina, M.V Maksutin (2007), Mistseve samovriaduvannia v zarubizhnykh krainakh: navch. posibnyk dlia studentiv BNZ, yaki navchaiutsia za spetsialnistiu "Yurisprudentsiia" [Local government in foreign countries: teach. A guide for undergraduate students studying in the jurisprudence] / under ed. AS Prudnikova - M.: UNIT1-DANA: the law of law, pp. 271.

5. Czech Republic [Electronic resource] // Wikipedia. URL: ttpi//ru.wikipedia. org/wiki/\%D7\%E5\%F5\%E8\%FF (revision date: 02.02.2018).

6. RozhodnutH bstavnHho soudu IleskG republic 35/1994 Sb. (PI 16 5/93; Svazekc 1; N61ezc 4; 35-40) - 19.1.1994*).

7. Usta Ceske republiky. Listina zakladnich prav a svobod // Uplne Zneni. $2003-138 .-$ s. $1-192$.

8. Zakoii “o obcich (obecni zrizeni)" ze dne 12. dubna 2000 roku, 1128 // Sbirka zakoiiu CR. - 2000 - 138-S. 1737-1764.

9. Zakon "o kiajich (krajske zrizeni)" ze dne 12. dubna 2000 roku, 1129 / / Sbirka zakonu CR. - 2000 - 138 - S. 1765-1782.

10. European Charter of Local Self-Government dated 15.10.1985, ratified dated July 15, 1997, No. 452/97 RP [Electronic resource]. - Mode of access: http://zakon2.rada.gov.ua/laws/show/994_036. 
The problem of correlationship between European principles of law...

THE PROBLEM OF CORRELATIONSHIP

BETWEEN EUROPEAN PRINCIPLES OF LAW

AND CHISTIAN VALUES IN THE CONTEXT

OF CURRENT CHALLENGES

\section{Nesprava Mykola ${ }^{1}$}

DOI: http://dx.doi.org/10.30525/978-9934-571-29-9_9

Abstract. The article deals with the problem of correlationship between European principles of law and Christian values. The author analyses the causes of current European legal system's axiological crisis. Practice has shown that the secularist principles enshrined in the Treaty of Lisbon have led not to the dreamed multiculturalism, but to the erosion of European identity as the basis of cultural-civilizational association. The historical and philosophical methods allow to reveal the role of Christian values in the creating of European law. The Christian spirit permeates the constituent documents and basic legal acts of the EU and the Council of Europe. European principles of law are based on humanistic values such as human dignity, freedom, equality and solidarity. These European values have their own sources in the Biblical commandments. Love, charity and right to life are the fundamental principles of the Christian humanism. Human dignity as an ethical category acts as an axiological and teleological core of law principles. Such axiological pillars as freedom, justice and responsibility are the connecting links in the relation between European principles of law and Christian values. The author shows the need for the legal state as a guarantor of the balance of human rights and freedoms with duties and responsibilities as higher Christian virtues. Divine origin of law and its subjective perception as justice explain the spiritual foundation of the Rule of Law principle. The Rule of Law establishes the supremacy of truth and justice, over formal legacy and political ideology; the priority of human rights over the interests of the state; non-interference of the state with private life, especially in matters of faith, and self-government of civil society structures, including religious organizations. Thus, it can be considered proven

\footnotetext{
${ }^{1}$ Candidate of Philosophic Sciences, Associate Professor, Associate Professor of the Department of Social Sciences, Dnipropetrivsk State University of Internal Affairs, Ukraine 
that the Christian values constitute the axiological basis of European law. The author argues that these values have to be implemented in the legal norms and must remain a powerful factor that regulates social relations, even in a secularized Europe, especially in such sensitive areas as family, the birth and education of children, and the care for those in need. Europe should abandon any moral permissiveness. Europeans have to recall the Gospel commandments and the principles of self-restraint, responsibility and solidarity inherent in the Christian values and to consolidate them at the legislative level.

\section{Introduction}

At the end of the XX and early XXI centuries, the European Union experienced a period of creative inspiration and unprecedented expansion. However, in the second decade of the new millennium, this unique international association has plunged into a deep crisis. Financial, economic and socio-political problems intertwined in one club. These negative processes led to an increase in the positions of euroskeptics, which puts hopes for solving these problems faster at national institutes than at pan-European ones. As a result, practically in all EU member states, the centrifugal forces began to overcome their integration intentions, and Britain even decided to withdraw from the European Union. Thus, there is a real threat of EU disintegration. This threat put on the agenda the need for a systematic update of the European Union. Obviously, the restoration of the building of the European Union must begin from its basic structure - the legal system. But for this, first of all, it is necessary to recall the value fundament that this construction holds. Thus, the research problem is stated as follows: how can Christian values affect the reform of the European legal system? The current paper aims to reveal the role of Christianity values for the design of EU integration's legal framework and to substantiate the importance of the Christian interpretation of such fundamental principles of European justice as humanity and the Rule of Law in the context of modern challenges. The definition of the axiological basis of European law has fundamental importance for the scientific analysis of its moral content in order to propose the prospects for further development, and practical improvement of EU law basic provisions. Understanding the moral basis of European law will also help to direct law-making activity in Ukraine towards approximation of Ukrainian law with the standards of the European Union more efficiently. 


\section{European identity and the Christian spirit of the EU Constituent Acts}

In a broad general sense, European law is a complex of legal systems, united by the common cultural and civilization tradition of Europe. In a narrower concrete sense, European law means, in the first, as the supranational legal basis of the European Union, and as the acts of the Council of Europe too. Last year the European Union celebrated three commemorative anniversaries. On March 25, 1957 the Treaty establishing the European Economic Community was signed. This organizational structure ensures the social and economic integration of Europe for 60 years. The quarter-century since the signing of the Maastricht Treaty, which laid the foundation for the European Union itself as a unique international establishment, was marked on February 7, 2017. The 10th anniversary of the signing of the Lisbon Treaty, which is still called the EU's small Constitution, and launched a qualitatively new stage in the functioning of the Union, was celebrated on December 13, 2017. These acts are of enormous importance, because they have created the framework of the modern European legal system. However, the jubilee year turned out to be a 'celebration with tears in the eyes' for the EU - so many cardinal problems fell on Europeans at the same time.

George Soros, who is known for his ability to look into the future, evaluates the crisis in the European Union more disturbingly. "The European Union really broke. It has ceased to meet the needs and aspirations of its citizens. It is moving to a chaotic disintegration that will leave Europe in a worse condition than what we would have if the European Union had not been created at all, - the authoritative analyst stresses. - Yes, it must be admitted that the EU is built incorrectly. But we should not give up. After Brexit, all those who believe in the values and principles on which the EU was founded should unite in order to preserve it, but in a substantially updated form" [1]. Under pressure from a number of challenges faced by the EU, the President of the European Commission, Jean-Claude Juncker, recognized the need to discuss the further model for the integration of countries on the continent. The leaders of the major European institutions aim to improve governance to the extent possible under the current EU treaties, extending the steps taken since the financial crisis. However, fundamental policies involving substantial sovereignty sharing remain vague. Since they require a meaningful EU treaty change, they have been put on the back burner, ostensibly to be brought forward after the UK referendum and the elections in France and Germany. But, as Themis Themistocleous 
and Ricardo Garcia note, given the time required to effect a meaningful treaty change, the current institutional framework will remain in limbo for the foreseeable future, leaving Europe vulnerable to shocks [2, p. 22]. In an attempt to present a new format for integration in which the European Union would be able to overcome the existing crisis, the European Commission on March 1, 2017 presented a White Paper on the future of Europe by 2025 . However, instead of the expected single model for the future of the $\mathrm{EU}$, the document offers five separate scenarios for the integration process [3]. This fact testifies to the inability of European officials to outline clear prospects for a united Europe. In our opinion, such confusion is explained by the issue that the EU's value foundation, laid down at its genesis, has been thoroughly washed up over the past decade.

While defending the importance of this foundation of the European Union, Kadri Kaan Renda revealed the content of ideological disputes. which unfolded during this period among the Europeans. He draws attention to the existence of two interconnected debate platforms that relate to the content of the current stage of European integration. The first outlines the debate between supporters of a liberal market economy (whose ideology usually has Protestant roots) and their opponents - advocates of a social market economy (whose ideas are based on the Catholic principles of solidarity). The second is the debate between those who believe that the basis of European integration should be the values of freedom, including multiculturalism, on the one hand, and those who defend the position of the need to protect traditional values - on the other [4]. In this sense, he opposes the concept of secular and multicultural Europe, on the one hand of the dichotomy, to the concept of Christian and anti-multicultural Europe, on the other hand.

It should be noted that the Lisbon Treaty, which was signed by the leaders of the EU member states in 2007 and came into force in 2009, enshrines the basic principles such as pluralism, tolerance, solidarity, non-discrimination both within member states and outside of them [5]. Although the Christian parties demanded the inclusion in this document, which defines the main directions of the restructuring of the European Union, also a provision on the prominent role of Christian values in ensuring European unity. In this sense, they emphasized the Christian roots of Europe and advocated that European identity and ideals can not ignore the role of Christianity in their formation. For them, the European idea must be in line with Christi- 
anity. In this regard, Kenneth Houston points out that even before the controversy over the Invocatio Dei, proposed for inclusion in the preamble to the European Union's defunct Draft Constitution, the role of religion in European integration had moved toward the centre of political consciousness [6]. However, the signatories of the document contrary to the recommendations of the clerics refused to include the provisions on Christian values as the basis of European integration, although they mentioned the significance of religion as a whole. According to Sergey Mudrov, the text of the Lisbon Treaty reflects the struggle between religious and secular actors [7]. So, as a result 10 years ago the position of secular multiculturalism has overcame. However, dramatic events unfolding recently in the European Union - the onslaught of migrants from the Muslim countries of the Middle East, a surge in Islamist terrorist attacks, which in turn resulted in the strengthening of ultra-right parties and, finally, led to Brexit - have shown that the rebuilding of the European palace on the principles of secularism led to the it cracking.

And in this regard, it is important to emphasize that the consideration of the European integration is based on the fact that an identity is the leading motive of some socio-political association. Speaking about self-identification as a core of civilization, Samuel Huntington wrote: "Throughout history, civilization represented the highest level of identification for people. Civilization is the highest cultural integrity. Civilizations are the largest "we", within which each feels himself culturally at home and distinguishes from all other "they" [8, p. 43]. Obviously, in the second decade of the twenty-first century the Europeans began to lose sentiment of a cultural home coziness on their own continent. The British are hoping to escape from someone else's influence over the Channel, more and more Frenchmen in search of salvation of what Madame de Stal called 'penser a l'europeenne' (to think as European), hope for Marin Le Pen, voices of revenge seeker, who got the motto 'Germany for Germans!' from the Nazi grave, became louder in in Germany, the position of the euro-skeptics is intensifying in Hungary and Poland. These facts indicate that the existing secular EU multicultural project has created ambivalent and controversial feelings about the establishment of a European identity.

And so, it should be reminded that the European project was conceived as a value-oriented civilization association from its beginning. Robert Schumann, one of this project's developers, believed that European reunion 


\section{Nesprava Mykola}

would not be possible without "inspiration coming from its Christian origins", and Europe is "the embodiment of universal democracy, in the Christian sense of the word" [9, p. 50]. The idea of a united Europe, which was embodied in the Treaty of Rome on the establishment of European Communities 60 years ago, has deep roots based on Christianity. Most scholars agree that organized Christianity appears as a unifying force on the continent since the Middle Ages. Describing the historical process of forming the concept of Europe as a holistic entity, Norman Davis points out that in the absence of common political structures, European civilization could only be determined by the criteria of culture, the special significance of which usually gives the underlying role of Christianity [10, p. 7]. In addition, the English historian underlines the role of Islam as a controversial factor in European integration. "The emergence of Islam has defined the boundaries of that new and compact entity, which was called the Christian world, - he writes. - This world was the stronghold that allowed Europe to self-determination" [10, p. 189]. Consequently, the historical lessons and realities of today lead to the conclusion that the need to preserve European identity puts on the agenda of current EU policy the task of changing the principles of the integration model. Challenges coming back to Europe by the Muslim world in the form of mass migration and radical terrorist groups, require the return of traditional Christian values not only to the consciousness of Europeans, but also to the rules of setting up a common European home.

Those who really care about the future of the European Union should remember the Jacques Delors's prophecy, which in 1992 declared that "if in the next twenty years we will not give our soul to Europe, taking into account its spirituality and meaning, then the game will be lost". According to K. Houston, during the decade of J. Delors's tenure as European Commission President (1985-1995), the involvement of religion played a more prominent role in strategic and affective considerations for further European integration [6]. The basic documents developed under his leadership allowed the European communities to transform into the European Union. So, Christian Democrates' ideas provided a powerful impetus to the process of creating the European Union.

Reflecting on the challenges and perspectives of the EU, Charles Taylor notes that no matter how anyone expresses their convictions and their position vis-à-vis the church, the roots of Europe are Christian, and there is no way to get rid of it. The scholar concludes that the first general point is 
the obvious fact that religion has often been and continues to be an important component of many political identities. This is clearly visible, in some cases, when it acts as the most important marker recognized as insiders and outsiders. But religious identity also plays a different role - as the basis of general, ethical, constitutional principles [11, p. 20-22].

\section{Human Rights and Christian Humanism}

In the context of this study, particular attention should be paid to the fact that European humanistic values define the formation of the European law principles. In general, references to these values are contained in the Charter of the Council of Europe (1949), reaffirming the devotion to the spiritual and moral values which are the common heritage of their peoples and the true source of individual freedom, political liberty and the Rule of Law, principles which form the basis of all genuine democracy [12]. In the more elaborated form, the designated values were enshrined in the Maastricht Treaty (1997) and specified in the Lisbon Treaty (2007) on the European Union as follows: "The Union is based on the values of respect for human dignity, freedom, democracy, equality, the rule of law and respect for human rights, including the rights belonging to minorities. These values are common to the Member States in a society in which pluralism, non-discrimination, tolerance, justice, solidarity and equality between women and men prevail" [13]. A broad interpretation of the axiological foundations of the EU provides the Charter of Fundamental Freedoms of the European Union (2000): "Conscious of its spiritual and moral heritage, the Union is founded on the indivisible, universal values of human dignity, freedom, equality and solidarity; it is based on the principles of democracy and the rule of law. It places the individual at the heart of its activities, by establishing the citizenship of the Union and by creating an area of freedom, security and justice" [14].

The analysis of basic legal acts shows that European values are complex spiritual and moral formation based on the principles of humanism. But in order to preserve these principles from destruction, it is necessary to find their roots and strengthen it. Some scholars, and no such few, especially in Europe, argue that this is rooted in secularism. Speaking about the humanist foundations of human rights and freedoms, they oppose anthropocentric worldview to theocentric. Considering rationalism as the driving force of development, including the system of law, secularists consider religious 
beliefs as obstacles to progress. They value the Rule of Law from the point of view of the existence of secular laws, and human rights in their understanding - is such a universal law, which is developed by people for people [15]. However, in our opinion, such an approach is superficial and does not reflect the depth of the valuable understanding of the concept of "human rights and freedoms".

And although, indeed, humanistic principles were first obtained by legal consolidation only at the end of the XVIII century, it is safe to assert that they were formed for centuries in the framework of Christian ethics. In this context, it is interesting to mention the statements of Alcide de Gasperi on the content of Christian heritage in European civilization: "When I say that Christianity stands at the origins of European civilization, I do not intend to pick up any exclusively confessional criterion for assessing our history. I point to a common European heritage only, to the moral that emphasizes human and his responsibilities" [16, p. 112]. There is no doubt that philanthropy is a distinctive feature of Christianity. In the Gospel, we find not only a clear commandment: "Love your neighbor as yourself" (Matt. 22:39), but also a more complicated cognitive model: "Love your enemies, bless those who curse you, who hate you, and pray for those who offend you and lead you, so that you may be the sons of your Father in heaven" (Matt. 5: 43-46). In a special way, Christian humanity and solidarity are expressed in the words of St. Paul: “... Does one member suffer, all members suffer from it? and when one member rejoices, all members rejoice with him" (Rom. 3: 37-38). All these are the laws of Christian life. This content of Christian ethics - charity, love and respect for the dignity of every human being as the creation of God - was the identifying marker of Europe and determined the further humanist orientation of European law for centuries.

The right to life is the basis of the human rights system. The secular statement in this regard is quite simple: the individual's right to life is conditioned only by the fact that he is a human. But it is noticeable that this formula lacks the evidence base. A more persuasive approach is that based on the Christian conception of man as God's creation. "Christians do not speak of human rights as 'natural rights', for this phrase suggests that human rights are merely self-evident characteristics of the natural order. - Robert Terer emphasizes. - Christians affirm that human beings have rights not because they are part of the natural order, but because they are loved by God" [17]. 


\section{The problem of correlationship between European principles of law...}

From the Christian faith in the creation of human like the image of God to participate in the fulfillment of the Divine plan of human and the world logically derived another basis for understanding the concept of human rights concept - the dignity of the human person. Human dignity is conditioned by the existential self, the desire to safeguard which gives impetus to the genesis of human rights. This concept is the key to all Christian denominations, because it is through it that its interpretation of the humanistic content of the Gospel finds its interpretation. "Therefore Christ, God and man, is the deepest source and guarantee for the dignity of the human person, Baas de Gaay Fortman stresses. - The Christian Faith is seen as the deepest foundation of all human rights. It illustrates how Faith-based approaches to human rights may even lead to a complete synthesis of two missions that are separate in origin and principle" [18].

Christian axiology of human rights distinguishes the value of life from human dignity. Life is given by God, and dignity is acquired by human. The person becomes dignified by doing good. Principles of good are given in the biblical commandments. Hence, there are two types of freedom: internal freedom from evil and freedom of moral choice. Freedom from evil is invaluable. Freedom of choice is of value, and personality - dignity only when a person chooses the good. On the contrary, when an individual chooses evil, freedom of choice leads to self-destruction and harms the dignity of man and social morality. Consequently, immoral dignity does not occur, and therefore the separation of the concept of human rights and freedoms from morality means its continuous profanation. Thus, human rights can only be said if one or another doctrine recognizes human dignity as a result of free choice in favor of good before the temptation of evil. Contrary to the groundless accusations of anti-clericals, it is Christianity that carries such a primitive humanistic assertion, arguing that God not only created man, but also became a man in the image of the Savior, without dissolving man in Himself. In the words of Richard Neuhaus, Christians affirm that only a transcendent understanding of the dignity of the person will provide a foundation for a Christian doctrine of human rights [19].

As a subject of moral consciousness, which is radically different from the environment by being able to know God, human in his behavior must be guided by the orders of the moral law, which is the embodiment of Divine Providence. Accordingly, this law, which Immanuel Kant calls 'categorical imperative', has an unconditional and a priori nature, it is not conditioned 
by external factors and forms the inner essence of human. The categorical imperative proclaims: "Act so that the maxim of your behavior could be at the same time the principle of general legislation" [20, p. 234]. In fact, this imperative is the philosophical formalized commandment of Christ, who proclaimed in the Sermon on the Mount: "All that you want that men do to you, then you also do them" (Matt. 7:12).

And here we are faced with the dilemma of freedom, which consists in the fact that the freedom of one person ends where the freedom of another begins, so it is impossible to live in society and to be free from it. "A human receives from God his essential dignity and, with it, the ability to exalted himself above any social order in search of truth and goodness, - Pope John Paul II noted. - However, it is due by the social structure in which he lives, also by the education and the environment" [21]. Freedom allows a person to succeed in ascending to spiritual perfection, but at the same time includes the danger of disobedience, the failure to subordinate to God, and through that - the fall, the tragic consequence of which is the existence of evil in the world. "All is allowed to me, but not everything is useful. Everything is allowed to me, but not everything is coming", - Apostle Paul proclaimed. Let nobody seek his own, but each one [benefits] of another ... for what would my will be judged by another's conscience?" (1 Corinth. 10: 23-24, 29). Freedom without responsibility and love leads in the end to the loss of freedom. Considering this dilemma, I. Kant relied on Christian postulates and emphasizes that duty is the highest form of moral behavior [20, p. 342].

The relationship between morality and law, which is reflected in the existential dilemma of the corelationship between human rights and freedoms, on the one hand, and duties and responsibilities, on the another hand, is a central theme in the debate that unfolds around the values of European law. "Such themes are found in current debates - crucial debates in which the requirement for truth and integrity (meaning) sometimes collides with the idea of liberty, - Zaki Laïdy asserts. - The Christian European movement has in effect not made up its mind whether to accept the idea that the invasive market principles can dispense with any form of transcendence. It shows a reluctance to accept that liberty might become the absolute that would be the basis for founding Europe to the detriment of a search for a certain truth" [22, p. 69].

The controversy around the concept of freedom in the Christian discourse on human rights is closely linked to the philosophical dilemma 
'human and society'. "In the name of a universally defined 'human person' it is always possible to consider itself as exempt from any obligation to a particular community, - Alain de Benoit shows. - Absolute of humankind faces then with the absolute of individual person" [23]. At the same time, it is important to put attention to the fact that while the liberal philosophy of human rights finds its starting point precisely in a separate personality and in its individual choices, the Christian conception of human rights, formulates the human dignity as a priority of duties towards his neighbors in compare with their own rights. Analyzing the features of the Christian tradition, Lyudmila Ivanova argues that law thinking in Christianity does not begin where a person finds the presence or absence (limitation) of his/ her own rights, but where he/she respects the rights of another person and is humbled before them, is humbled before his/her freedom, allows it to be different [24].

Current discourse on human rights and freedoms involves such pressing issues as abortion, euthanasia, biomedical reproductive technologies, same-sex marriages. It should be noted that Christian morality in such cases clearly requires the restriction of freedom in favor of responsibility. Alessandra Nucci notes that many Eastern European countries are facing increasing pressure from Western nations to abandon their traditional Christian values and religious heritage. The ethical issue that causes the most universal outrage, in both the East and the West, is the rampant financial corruption in political circles, an evil that no one questions. Instead, there are deep disagreements in the areas of 'life issues', the family, and education. There is no lack of examples of what the assault on traditional principles in these areas can look like in the West. The attacks are repeated and progressive. What we do know is that the people underwent a vicious and determined undermining of tradition, and particularly of the principles which, in recent years among Catholics, have come to be known as 'non-negotiable': life, the family, and education [25].

This is particularly marked in relation to the right to a family and freedom of marriage. Pope Francis I and Patriarch Kirill declare in their Joint statement: "We regret that other forms of cohabitation today are compared with a family based on marriage as an act of free and faithful love between man and woman, while the consecrated biblical tradition of the idea of paternity and motherhood as a special vocation of men and women married out of public consciousness" [26]. And in this connection, 
it should be emphasized that the biblical notions of marriage were the basis of Article 16 of the Universal Declaration of Human Rights [27] and Article 10 of the International Covenant on Economic, Social and Cultural Rights [28]. "The intensity of the struggle can be judged by the fact that almost all the countries now sandwiched between a coercive new West and a coercive old East are dashing to lock the definition of marriage into their laws, - A. Nucci stresses. - More and more countries are taking action to include bans on same-sex marriage into their constitutions, including Belarus, Bulgaria, Finland, Hungary, Latvia, Lithuania, Moldavia, Montenegro, Poland, Serbia, Slovakia, and Ukraine. An amendment of this kind is currently pending before Parliament in Macedonia" [25]. Defending the Christian axiom of life as the sacred gift of God, the Church regards abortion and artificial insemination as a great sin. It is important to emphasize that the Christian interpretation of human rights insists on denying any nihilism. The Christian tradition stands for the right to life and against the 'right' to death, for the right to creation and against "right" to destruction, for the right to love and against same-sex marriages, for freedom of speech and against slander and insult.

The dilemma of freedom arises also in the process of assessing the principle of freedom of conscience and religion. From the standpoint of understanding the axiological essence of the concept of human rights and freedoms, it is important to emphasize that its approval at the initial stage is connected with the recognition of the right to freedom of religion within the framework of Christianity. But secularism in its radical form - anticlericalism, taking over the right to own the truth in the last instance, acts as a malicious violator of human rights and deploys democratic societies towards totalitarianism in the end. "The process of European integration, which began after centuries of bloody conflicts, has been perceived by many with hope as a pledge of peace and security, - Pope Francis I and Patriarch Kirill note. - At the same time, we warn against such integration that does not respect religious identity. In particular, we see that the transformation of some countries into secularized societies, alien to any memory of God and His truth, entails a serious danger to religious freedom. We are concerned about the current restrictions on the rights of Christians, not to mention their discrimination, when some political forces, guided by the ideology of secularism, which so often becomes aggressive, seeks to push them to the brink of social life" [26]. It should be defined that under this term secularism must 


\section{The problem of correlationship between European principles of law...}

be understood as anticlericalism, because freedom of religion is not one and the same thing as freedom from religion.

The anticlerical model sooner or later degenerates into aggressive atheism, which undermines the spiritual foundations of society. The metastases of this destructive process are manifested in many EU countries, and it causes the Union's valuable crisis. A. Nucci disturbs that people in many European countries are embarrassed or afraid to talk about their religious affiliations. Holidays are abolished or even called something different; their essence is hidden away, as is their moral foundation. And people are aggressively trying to export this model all over the world. I am convinced that this opens a direct path to degradation and primitivism, resulting in a profound demographic and moral crisis [25]. So, the question arises: will the modern European concept of human rights develop towards developing principles that balance the various freedoms in society, or it will give privileges for certain groups to impose their understanding of human nature and human relations with others?

The aspiration to solve the dilemma of the relation of freedom and responsibility leads to the necessity of substantiating the cardinal virtue justice. In this context, it is important to note that in the Christian tradition, the notion of freedom and responsibility necessarily correlates with the notion of justice. It should be stressed that justice is relational, so it is manifested through the relations between actors. "The human person does not have rights as an individual, but in relation to others in community and ultimately in relation to God. Thus, Christians affirm that human rights are derived from faith and involve duties to God and one's neighbor, $-\mathrm{R}$. Traer emphasizes. - Human rights are not only derived from divine rights but also constitute duties toward others. Christians assert that because God loves all people, all people have rights and the corresponding duties to respect the rights of all others". [17]. The Christian demands of limiting individual freedom in favor of responsibility come from here. And so, human must again and again comprehend the difficult art of earthly human coexistence as a ministry, purpose, duty, including legal.

Expanding the content of the assessment of social relations, based on the criterion of justice, Thomas Aquinas pointed out that an act is 'just' or 'legal', if it is coordinated with another person by means of some equality [29]. So, the concept of equality logically comes from the category of justice. This notion of justice is a distinctive feature of European principles of 
law that interpret justice in terms of social equality and economic solidarity. Christian tradition requires not only to build the economy on a moral basis, but also through its active service to man, following the teachings of Apostle Paul: "By working, we must support the weak and remember the words of the Lord Jesus, for He Himself said: "It is more blessed to give than brothers" (Acts 20:35). Solidarity and subsidiarity are fundamental principles of European law. Unfortunately, these principles are only declared, but not implemented in Ukraine.

Other fundamental principle of European law - non-discrimination comes from moral values too. On this subject, the Christian tradition has a clear position. Christians believe that "God from the same blood has formed the whole human race for living all over the face of the earth (Acts 17:26) and that in Christ "there is no Jew or Greek, there is no slave, nor free, no man, nor woman because you are all one in Christ Jesus" (Gal. 3:28). This fruitful source has to continue to nourish the value content of the human rights concept that is the bar of European international and national legal systems. Thus, Christian values do not accept the so-called 'positive' discrimination that creeps up across Europe.

\section{The Rule of Law and Justice}

Europeans mean justice as mutual responsibility of a citizen ('responsible individualism') and of a state ('responsible sovereignty'). However, the correlation between the basic principle of human rights, on the one hand, and principle of state sovereignty, on the another hand, is very contradictory on practice. "Unquestionably then, the fellowship that human beings are called upon to establish is not just a matter of envisioning the others as free and equal creatures but also of doing justice and living together in peace, - B. G. Fortman states. - Naturally, the acceptance of that responsibility for protection of the human dignity of everyone requires more than just a legal basis, no matter what sorts of legal mechanisms for its realization may have been created. Indeed, the ratification of treaties, the establishment of international courts of human rights - access to which, and hence compliance, is entirely voluntary for states to enter into - and the development of human rights jurisprudence are not enough. The moral grounds for a conviction upon which responsible behaviour rests have to be constantly nurtured on the basis of a worldview shared by those concerned" [18]. And here the problem of the correlation between the Rule of Law and the institution of Legal State rises topically. 


\section{The problem of correlationship between European principles of law...}

The categories 'Rule of Law' and 'Legal State' are cornerstones of the modern European legal system, the corelationship between which has a dialectical character. Sergey Maksimov puts the attention on the internal contradiction of an ideal based on these categories. He shows that the emphasis of different ideological platforms on its various sides (enlightened absolutism sought full rationalization of social life, and liberalism through the idea of inalienable rights of the individual substantially restricted the scope of state intervention) created two different models of the Rule of Law, which are theoretically substantiated and practically applied. There are the so-called Gobbs model, or the formal concept of the Rule of Law, and the Lokk model, or the substantive concept of the Rule of Law. If the first model constrained the arbitrariness of power by the existence of laws binding on all persons and the same for all their application, then the second requires the certain quality of these laws - they must protect human rights. That is, restrictions are imposed not only on the executive and judicial branches of power, but also on legislative power [30, p. 31]. It should be noted that in the process of further development of philosophical and law thought, the first model was found in the German-continental concept of a Legal State (Rechtsstaat), where the law merges with the legal normes issued by this state in fact, and the second model was justified by the Anglo-Saxon concept of the Rule of Law in which law goes ahead of the state.

The collision between these models has not only the nature of scientific discussion, but also a dramatic historical manifestation. "All Christians agree that human rights laws are not authoritative merely because they are laws passed by the state. The Nazi regime is a vivid example of the injustice that can be done through the lawful edicts of a state. Moreover, the death of Jesus, though unjust, was lawful, - R. Traer notes. - The law is to be obeyed because it is right, not simply because it is the law. The standard for the law must be sought outside the law" [17]. So, the Rule of Law implies that the legal norm must be enforced because it is morally justified, and not simply because it is a law. Thus, the spiritual and moral origins determine the assertion of the Rule of Law over formal normative and legal acts of state authority.

However, the diligent pursuit for the benchmarks of secularism and positivism, which were put forward by liberal Rule of Law theories at the time of Enlightenment, led the philosophers to a standstill. After all, references to natural law and social contract as the primary sources can not be accepted 
as logical arguments in favor of substantiation of the Rule of Law principle, because they send us to the same conventional roots, which, according to these theories, has the state. In this way, liberalism recognizes the right and the state to be equal in origin, and, therefore, the priority of law can not be considered proven.

In the idealistic-critical dimension the Rule of Law is an idea that encompasses a particular type of interaction between human and power and, in general, focuses on the fact that the authority must be limited by certain principles and norms, and could not go beyond these limits [30, p. 28]. Convincing arguments in favor of understanding the Rule of Law are found in Kantianism. I. Kant defined the state as an association of the "plurality of people subordinated to the legal laws" [20]. At the same time, the thinker distinguished the concept of 'law' and 'legacy'. Law as a social phenomenon is a cumulative product of individual ethos, which have a categorical imperative for a rod. Thus, the realization of the principle of the Rule of Law is due to the peculiar man's sense of justice, which should be understood as the subjective human perception of the supreme God's law. The legacy is a formal act of the state, which is intended to give the law the force of coercion. This content I. Kant put in the notion of Legal State, and in this sense, this concept is used as a criterion for membership in the European Union.

Thus, the Rule of Law means that state power must be limited by just law in its supreme Divine sense, in the sense that such spiritual values as good, truth, morality, conscience and justice were origin by God. Such perception of the Rule of Law is a born European social tradition, which, unfortunately corroded by anticlericalism. Thus, in the updated model of the Rule of Law, both responsible individualism and responsible sovereignty must be formed not only by legal levers, but also by the moral guidelines contained in the Gospel commandments. Spiritual responsibility is based not on fears of condemnation and sanctions, but on faith in God's law and His higher judgment, which alone guarantees both the inevitability of punishment and eternal grace. In F. Dostoyevsky's word warned by the lips of his hero: "If there is no God, then everything is allowed!" [31, p. 79].

It is important to emphasize that in the European democratic paradigm the concept of human rights was formed as a counterweight to the authoritarian state power. The separation of a certain spectrum of social relations from state intervention is the basis of civil society. Ideologies that deny the fundamental value of human dignity, at least in favor of something else, 


\section{The problem of correlationship between European principles of law...}

'higher' (nation, state, social or professional group, party, sects, etc.) - are not legal because they are immoral. Supremacy above an 'image and likeness of God' can only be God who judges, punishes, but above all shows charity to human. Therefore, for the Christian ethics, the content of human rights and freedoms exceeds any political ideologies.

Such Rule of Law interpretation, which relies on justice, not on the legal norms, is inherent for the Ukrainian social tradition. It has been confirmed, in particular, by the Orange Revolution (2004-2005) and the Revolution of Dignity (2013-2014). It should be noted that, on the contrary, in Russia, historically prone to authoritarianism, public opinion does not perceive the tradition of the Rule of Law, but the tradition of a strong state. The diametrically opposite attitude to understanding the concept of human rights and freedoms is one of the reasons for the value conflict between Ukraine and Russia.

But this does not mean that Ukrainian authorities do not try to justify the violation of human rights by so-called political expediency, which is often camouflaged for national interest and security. Attempts by some officials to regulate the order of sending church sacraments, to determine the availability of apostolic succession to the churches, as well as to close their eyes to forcibly seizing the premises of religious communities, being justified by the will of a some passionate minorities, are examples of the impolite atavism of the Bolshevik practice of violating human rights and freedoms. The principle of conscience's freedom, constituting the state's non-interference with private spiritual life, at the same time implies the individual responsibility for choosing his own path to God (in relation to children, such responsibility is borne by the parents). Collisions that have re-emerged in this area and stirred up public opinion in European countries, especially in Ukraine, raised the question: will the modern concept of Rule of Law develop in the direction to balance the different freedoms in society, or it will grant privileges for nationalistic authorities or marginal minorities to impose the understanding of human rights? The developing of European law principles on the basis of Christian moral values will answer this question and help to cope with the new challenges faced by Europe.

\section{Conclusions}

This study confirmed that Christianity is a marker of European civilizational identity and the spiritual core of its integration. Christian ethics 
fills the constituent acts of the EU with moral content. By ignoring the Christian "spirit of laws", the existing secular multicultural project of the EU has created ambivalent and controversial feelings about the establishment of European identity and the implementation of the European legal norms into the humanitarian sphere. Because the principles of European law are fed from the source of Christian humanism, having as a moral basis such values as the right to life, human dignity, freedom, equality and solidarity. The Christian spirit lies in the constituent documents and the main legal acts of the EU and the Council of Europe, even if they declare freedom of religion. Thus, it can be considered proven that the Christian values constitutes the axiological basis of European law. But in recent years these basic values have begun to erupt in Europe. It means that the soil leaves the underlying foundation of the European law system. Losing support, the entire building of the European Union began to shake. In order to relieve tension in society and revive the attractive energy of the legal system, first of all, the Lisbon Treaty as a small constitution of the EU, it is necessary to return the axiological basis - the Christian values - to its legal area. The theological and philosophical concepts of Thomism and Kantianism, substantiating the fundamental values of natural law, justice, equality, human dignity, freedom and responsibility, laid the foundation for the understanding of human rights as objective inalienable entities. This concept of human rights is a cornerstone of European legal system. Justice, as a human's reflection of the supreme God's law, serves as a criterion for the Rule of Law in Europe. Consequently, the principles of the Rule of Law, confessing freedom of conscience and establishing secularism as separation of the Church from the state, should not neglect Christian moral norms. These norms, even in a secularized Europe, must remain a powerful factor regulating social relations, especially in such sensitive areas as family, the birth and education of children, and the care for those in need. The aspiration for the revival of Christian values should cease to be a speculative slogan of nationalists and right-wing conservatives, and have to become a daily law-making mission of European authorities. Under the conditions of democracy, the embodiment of Christian priorities in the legal system does not repel others to the marginal periphery, but, on the contrary, consolidate society. Using the positive experience of combining the principles of European law and Christian values will contribute to the improvement of Ukrainian legal system. 


\section{The problem of correlationship between European principles of law...}

\section{References:}

1. Soros, J. (2016) Brexit and the Future of Europe. Project Syndicate. The Word's Opinion Page, 25 June. Retrieved from: https://www.projectsyndicate.org/commentary/brexit-eu-disintegration-inevitable-by-george-soros2016-06? barrier=true (accessed 21 February 2018).

2. Themistocleous, Th., \& Garcia, R. (2016) The future of Europe. UBC AG. Retrieved from: https://www.fundresearch.de/sites/default/files/partnercenter/UBS/ News/news_2016/European\%20economy_en_1217027.pdf (accessed 22 February 2018).

3. White Paper on the Future of Europe. (2017). European Commission, 01 March. Retrieved from: https://ec.europa.eu/commission/sites/beta-political/ files/white_paper_on the future of europe en.pdf (accessed 25 February 2018).

4. Renda, K. K. (2012) Understanding the European Integration through the Ideational Factors. Cezran International, 08 Sept. Retrieved from: http://cesran.org/index.php?option $=$ com content \&view $=$ article $\&$ id $=403 \% 3$ Aunderstanding-the-european-integration-through-the-ideational-factors \& Itemid=75\&lang=en (accessed 28 February 2018).

5. Treaty of Lisbon. Amending the Treaty of European Union and the Treaty Establishing the European Community (2007). EUR-Lex. Access to European Union law, 01 Dec. Retrieved from: http://eur-lex.europa.eu/legal-content/EN/ TXT/?uri=celex\%3A12007L\%2FTXT (accessed 28 February 2018).

6. Houston, K. (2011) Religion and European Integration: Predominant Themes and Emerging Research Priorities. Religion Compass, vol. 5, is. 8, pp. 462-476. Retrieved from: http://onlinelibrary.wiley.com/doi/10.1111/j.1749-8171.2011. 00291.x/abstract (accessed 01 March 2018).

7. Mudrov, S. (2016) Religion in the Lisbon Treaty: Aspects and Evaluation. Journal of Contemporary Religion, vol. 31, is. 1, pp. 1-16. Retrieved from: http://www.tandfonline.com/doi/full/10.1080/13537903.2016.1109863 (accessed 01 March 2018).

8. Huntington, S. (2003) Stolknovyeniye tzivilizatziy [The Clash of Civilizations]. Moskow: AST. (in Russian).

9. Vanheeswijck, G. (1997) How can we overcome a policy of inarticulacy? More Europe? A critical Christian inquiry into the process of European integration. Kampen: Pharos, pp. 49-58.

10. Norman, D. (2006) Istoriya Yevropy [History of Europe]. Moscow: Khranitel'. (in Russian).

11. Taylor, Ch. (2013) Religion and European Integration. Religion in the New Europe. K. Michalski (ed.) Central European University Press, pp. 1-22. Retrieved from: http://books.openedition.org/ceup/1271 (accessed 02 March 2018).

12. Statute of the Council of Europe (1949). London, 05 May. Official site of the Council of Europe. Retrieved from: https://rm.coe.int/1680716109 (accessed 03 March 2018).

13. Treaty on European Union (1992). Maastricht, 7 February. Official Journal of the European Union, C 326, 26/10/2012, pp. 0001 - 0390. Retrieved from: http://eur-lex.europa.eu/legal-content/EN/TXT/?uri=celex\%3A12012M\%2FTXT (accessed 03 March 2018). 


\section{Nesprava Mykola}

14. Charter of Fundamental Rights of the European Union (2000). Nice, Dec. 7. Official Journal of the European Union, C 326, 26.10.2012, pp. 391-407. Retrieved from: http://eur-lex.europa.eu/legal-content/EN/TXT/?uri=CELEX:12012P/TXT (accessed 03 March 2018).

15. Definition of the most basic European Values (2016). Creative Commons by EuropeanValues.info. Retrieved from: http://europaeischewerte.info/fileadmin/ templates/Documents/ewdef_en.pdf (accessed 03 March 2018).

16. Venner, G., \& Ferrara, O. R. (2009) Alcide De Gasperi and Antonio Messineo: A Spiritual Conception of Politics and a Pragmatic Idea of Religion? Religion, State and Society, vol. 37, no. 1 \& 2, (Special Issues), pp. 108-123.

17. Traer, R. (2015) Christian Support for Human Rights. Religion and Human Rights, vol. 3, no. 1. Retrieved from: http://religionhumanrights.com/Religion/ Christian/christian.fhr.htm (accessed 04 March 2018).

18. Fortman, B. (2011) Religion and Human Rights: A Dialectical Relationship. e-International Relations. 05 Dec. Retrieved from: http://www.e-ir.info/2011/12/05/ religion-and-human-rights-a-dialectical-relationship/ (accessed 04 March 2018).

19. Neuhaus, R. J. (1978) What do we mean by Human Rights, and Why? Christian Century, vol. 95. pp. 1180-1192. Retrieved from: http:/www.religion-online.org/ blog/article/what-we-mean-by-human-rights-and-why/ (accessed 05 March 2018).

20. Kant, I. (1995) Kritika prakticheskogo razuma [Critique of Practical Reason]. St. Petersburg: Nauka. (in Russian).

21. John Paul II (1991) Encyclical Centesimus annus. Ukrainian Catholic University: Institute of Religion and Society. (in Ukrainian). Retrieved from: http://irs.ucu.edu.ua/dzherela/sotsialni-entsikliki/ivan-pavlo-ii-centesimusannus-1991/ (accessed 05 March 2018).

22. Laïdi Zaki. (1998). A world without meaning: the crisis of meaning in international politics. Tansl by J. Burnham, J. Coulon. New York: Routlege.

23. Benoit, A. Religiya prav chelovyeka [The Religion of Human Rights]. Al'ternetivy printsipu ravenstva [The Alternatives to the Principle of Equality]. P. Krebs (ed.). (in Russian). pp. 3-28. Retrieved from: https://s3-eu-west-1.amazonaws.com/ alaindebenoist/pdf/religiya_prav_cheloveka.pdf (accessed 23 February 2018).

24. Ivanova, L. O. Religiya I prava chelovyeka [Religion and Human Rights]. Library nauchnoy i uchyebnoy lityeratury [The Library of Scientific and Educational Literature]. (in Russian). Retrieved from: http://sbiblio.com/biblio/ archive/ivanova_religipravachel/ (accessed 23 February 2018).

25. Nucci, A. (2015) Europe's War on Christian Ethics. The Catholic World Report, 28 May. Retrieved from: http:/www.catholicworldreport.com/2015/05/28/ europes-war-on-christian-ethics/ (accessed 03 March 2018).

26. Sovmestnoye zayavlienie Papy Rimskogo Franciska I Svyatyeyshego Patriarch Kirilla [The Joint Statement of the Pope Francis and His Holiness Patriarch Kirill] (2016). Habana, 13 Febr. Official site of Russian Orthodox Church. (in Russian). Retrieved from: http://www.patriarchia.ru/db/text/4372074.html (accessed 04 March 2018).

27. The Universal Declaration of Human Rights (1948). The United Nations General Assembly. Paris, 10 Dec. Retrieved from: http://www.un.org/en/universaldeclaration-human-rights/ (accessed 05 March 2018). 
28. International covenant on economic, social and cultural rights (1966). The United Nations General Assembly, 16 Dec. Retrieved from: http://www.ohchr. org/EN/ProfessionalInterest/Pages/CESCR.aspx (accessed 05 March 2018).

29. Foma Akvinskiy [Thomas Aquinas] (2010). O spravedlivosti, vopros 91. Summa teologiyi [About a Justice, question 58. Summa Theologiae]: in $12 \mathrm{t}$. S. I. Yeremeyev (ed.). Kyiv: Nika-Centre, t. VI. (in Russian). Retrieved from: https://azbyka.ru/otechnik/konfessii/summa-teologii-tom-6/ (accessed 02 March 2018).

30. Maksimov, S. I. (2016) Verkhovenstvo prava: svitohlyadno-metodolohichni zasady [The Rule of Law: Worldview Methodological Foundations]. Visnyk Natzional'noho Universytetu 'Yurydychna Akademiya smeni Yaroslava Mudroho' [Bulletin of the National University 'Yaroslav Mudryi Law Academy of Ukraine'] (in Ukrainian), no. 4 (31). pp. 27-36. Kharkiv: Pravo.

31. Dostoevsky, F. M. (2011) Bratya Karamazovy [Karamazov Brothers]. Moskow: Azbuka. 


\title{
JURISDICTIONAL POWERS OF PUBLIC ADMINISTRATION AUTHORITIES IN UKRAINE AND FOREIGN COUNTRIES: PROBLEMS OF EXECUTION
}

\section{Riabchenko Yaroslava ${ }^{1}$ \\ Zuj Valentina ${ }^{2}$}

DOI: http://dx.doi.org/10.30525/978-9934-571-29-9_10

\begin{abstract}
The article is devoted to the implementation of jurisdiction of public ad-ministrative authorities in Ukraine and foreign countries. The article defines administrative jurisdiction, its features and types in exercising jurisdiction by public administrative authorities in Ukraine and foreign countries. It is determined that the powers of the public administration are realized respectively to the types of administrative jurisdiction. Today, in order to tackle pressing problems of jurisdictional powers exercised by public administration authorities in Ukraine and foreign countries it is of paramount importance to carry comprehensive research. In this respect, the peculiarities of exercise of different administrative jurisdiction types, status of public administration authorities, criteria for division of administrative jurisdiction into types, conditions of exercise of powers should be brought to the forefront. On the theory of Administrative law and analysis of legal acts, academic publications and other sources, the research is aimed at describing legal regulation of jurisdictional powers exercised by public administration authorities. It should be emphasized that modern scientific legal publications tend to the following characteristics of administrative and jurisdictional activities: 1) a wide range of social relations protected by administrative and jurisdictional means; 2) a significant number of powers to impose administrative penalties, in comparison to other jurisdictional bodies; 3) a wide range of officials authorized to impose administrative sanctions; 4) the specialization provided by the laws to consider administrative and jurisdictional cases; 5) power to impose administrative penalties
\end{abstract}

\footnotetext{
${ }^{1}$ Candidate of Jurisprudence Sciences,

Assistant Professor of the Administrative Law Department,

Yaroslav Mudryi National Law University, Ukraine

${ }^{2}$ Candidate of Jurisprudence Sciences,

Assistant Professor of the Administrative Law Department,

Yaroslav Mudryi National Law University, Ukraine
} 
at the scene of the offense. The concept of administrative jurisdiction is considered from different points of view, provided in some legislative acts or studied by administrative law experts in relation to the role of those who are authorized to perform public administration jurisdiction. A key role is played by those who implement jurisdic-tional powers. They must act within law boundaries and in compliance with law to ensure effective protection of human rights and citizens. Thus, it should be noted that administrative jurisdiction is a totality of statutory provisions of public administration powers, including jurisdictional powers to deal with citizens' applications, to the relevant authority determined by the administrative acts, following the administrative procedural; individual administrative cases where administrative (disciplinary) coercion is imposed.

\section{Introduction}

Today, in order to tackle pressing problems of jurisdictional powers exercised by public administration authorities in Ukraine and foreign countries it is of paramount importance to carry comprehensive research. In this respect, the peculiarities of exercise of different administrative jurisdiction types, status of public administration authorities, criteria for division of administrative jurisdiction into types, conditions of exercise of powers should be brought to the forefront. The solution of the major issues would enable better development of an optimal model for proper exercise of the jurisdictional powers by public administration authorities in Ukraine as well as removal of final obstacles to public administration reform, also dependent on the updating of procedure legislation.

Executive authorities exercise their powers every day that is not part of administrative and executive activities, but their independent function. First, their powers are delegated to them by the legislator in order to "unload" the courts and to settle certain legal conflicts promptly. Second, jurisdictional powers of public administration authorities are becoming increasingly urgent to protect human rights and rights of citizens.

Thus, the executive authorities exercise jurisdictional powers every day, and this activity does not act as part of discharge-executive activity, but as an independent function of these authorities. Firstly, it is delegated to them by the legislative power to "unload" the judicial branch of power and to deal promptly with certain legal conflicts. Secondly, the realization of jurisdictional powers exercised by public administration authorities becomes 
extremely relevant, since the latter should be an instrument for the protection of human rights and citizen.

\section{Problem statement}

We will add that in connection with the process of intensive integration of our state into the European community, the cooperation with different structures of foreign countries in the process of implementation of jurisdictional powers exercised by public administration authorities for Ukraine becomes more extensive in the European community. Let us turn to history, and for the first time the notion of "public administration" in 1887 was introduced by the future 28th President of the United States, Woodrow Wilson, in an essay called "The Study of Administration", through which a separate scientific and educational direction received its further development. In this paper, Wilson wrote: "The purpose of administrative science is to determine, firstly, what the government is doing, and secondly, how it should carry out this activity effectively and with the lowest financial and energy costs". The emergence of a new form of governance in the public sphere has been driven by the need to modernize the organizational structures and procedures that they use to make all public sector institutions work better. Public administration refers to the effective functioning of the whole system of political institutions [1, p. 5-6].

\section{Survey methodology}

In narrow sense of the very notion of administrative jurisdiction, the reference sources define administrative jurisdiction (from Latin jus, jur- 'law' + dictio 'saying') as the set of legal powers of the relevant state bodies established by law or other regulatory acts to resolve legal disputes as well as to decide cases of offenses, that is, to determine legitimacy of the actions of a person or other objects, and consequently to impose sanctions on offenders [2, p.16]. Some legal scholars identify administrative jurisdiction with legal proceedings, justice, judicial proceedings, with court jurisdiction or judicial cognizance, the competence of a judicial body, as well as with powers to decide cases and impose penalties [3, p. 414]. Others classify it as the totality of powers of the relevant state bodies to settle legal disputes and cases of offenses or as administrative and procedural activity of the authorized executive bodies, that is, legal powers of government bodies and officials to make decision in individual cases and impose appropriate legal 


\section{Jurisdictional powers of public administration authorities in Ukraine...}

administrative sanctions [4, p. 409]. Moreover, as far as a public authority concerns, "jurisdiction" is defined as the legal power limits within which a certain public body is authorized to act [5, p. 32].

Given the foregoing, it may be noted that the understanding of jurisdiction has undergone some changes, and today it is defined as a set of powers of the relevant state authorities to resolve legal disputes and cases of offenses $[5$, p. 26] or as an administrative-procedural activity of authorized of executive power, that is, established by the legislative acts the activities of state administration and officials on the resolution of individual cases and the application of appropriate legal sanctions in an administrative manner [6, p. 409]. Therefore, the jurisdiction has a certain state-power direction, because it acts on behalf of the state. These functions are carried out and local governments are formed and their structures have certain rules of administrative law competence - competence, rights and duties (powers) are responsible for the acts or omissions within their own or delegated competencies involved in the administrative relationship regulatory or security nature, perform public, executive, regulatory, licensing, registration and control functions. It is noteworthy that the administrative entity is manifested in the local self-government in the exercise of functions performed on the basis of the powers delegated to them. This is stated in clause 5 of Art. 3 of the World Declaration of Local Self-Government, paragraph 5 of Art. 4 of the European Charter of Local Self-Government and has its reproduction in the norms of the Constitution of Ukraine (Part 3 of Article 143), the laws of Ukraine on local self-government and on local state administrations. The administrative and legal status of local self-government bodies is guaranteed by the state and is protected by state government that can take measures to protect the rights of local self-government bodies, for example, when these bodies refer to the Cabinet of Ministers of Ukraine, the President of Ukraine.

A significant place among the means of administrative legal protection of rights and legitimate interests of citizens is given to a lawsuit on administrative acts, which is considered in the order of administrative justice - special justice, aimed at resolving a dispute about administrative (public) law.

Consequently, one should agree with L. S. Anokhin, who claims that the "jurisdiction" covers the powers of law enforcement and law enforcement actors. These powers do not provide for the possibility of developing and adopting new rules of law, they are aimed at implementing the rules in 
force. Jurisdiction is inextricably linked with the functioning of the institution of legal liability, since the latter can only be realized within the jurisdictional process [7, p. 72-75].

In its turn, administrative jurisdiction is not only a type of jurisdiction in general, but also an integral part of executive and regulatory activity of state administration bodies, namely a specific type of law enforcement activity. With its help, the subject of public administration gives a legal assessment of the conformity of the object's behavior with the established legal requirements [8, p. 72-75].

V.B. Averyanov insists that the content of the institute of "administrative jurisdiction" must be legally consolidate in the relevant legal act accordingly to combine jurisdictional activity: a) executive authorized to hear complaints of citizens and legal entities for illegally taken decisions, both lower power and subordinates, that is, the scope of administrative appeal (administrative "quasi-nationality"); b) executive authorized to apply measures of administrative liability (administrative extrajudicial justice); c) administrative courts (administrative judicial justice) [9, p. 193-195]. Guided by the sectoral affiliation of legal relationships that arise in this case, one can distinguish criminal, civil, legal, disciplinary, administrative jurisdiction. Thus, administrative jurisdiction is part of the jurisdiction of the state as a whole. In this administrative jurisdiction inherent features of the general concept of "jurisdiction", also has a number of specific features [7, p. 492]. Since the system of constitutional guarantees of human rights and citizens' specific role for judicial control of public administration is a significant factor with regard to the activities of government agencies operating in the field of public administration is taking into account the specific administrative proceedings. The subject of the dispute is the decision, action or inaction of the public authority, therefore it would be important to establish that not only a certain state authority or its official, but also Ukraine as the state as a whole, can be involved as a defendant (party) in a case. This follows from the practice of the European Court of Human Rights. Under present conditions, this is quite possible, since in the national court a substantive jurisdiction is provided for in disputes involving violations of citizens' voting rights, the right to participate in a referendum, the granting of citizenship and residence permits, in disputes concerning the recognition of a citizen as a disabled person, a participant in hostilities for the protection of the Fatherland, the granting of retirement benefits, the seizure of property for state needs, etc. 


\section{Jurisdictional powers of public administration authorities in Ukraine...}

Therefore, the emergence of administrative justice in a court (judges), appellate court and the Supreme Administrative Court of Ukraine provided the rules of administrative justice and this kind of judicial control of public authorities strongly developed. However, one of the main problems in this process is the formation of a judicial corps from authoritative, independent judges who would have special knowledge, proper theoretical and practical training in the sphere of application of the law in resolving disputes related to administrative-legal relations. It is obvious that the realization of a citizen's rights depends in part not so much on the law as on the discretion of the official, and only the court is able to terminate administrative arbitrariness.

Therefore, in the process of carrying out administrative and jurisdictional activities, public authorities, their officials and officers are called to ensure the protection of public relations, which are formed in the field of public administration, to fight administrative offenses, which are the most numerous variety among other types of offenses.

In the legal literature of foreign countries, it is believed that the jurisdiction of the authorities is to implement functions for the practical maintenance of personal security of citizens, for the protection of public order and public security, which has its components, i.e., is divided into administrative-supervisory, administrative and administrative-jurisdictional [10, with. 7; 9, p. 84].

It should be noted that for a more convenient conducting of the research one should take into account the division of legal systems of foreign countries into the general and continental. This division is caused by several reasons: the main one is that in the countries of continental law there are "written rules", that is, adopted by the highest legislative authorities, criminal, criminal procedure and other codes that regulate the activities of law enforcement agencies and the process of detection and prevention of offenses and punishment of offenders. And in the countries of the general (statutory) law they are detailed in systematic codes and no law enforcement bodies are governed by statutes (acts of Parliament) but by judicial precedents [11, p. 143].

As an example, the United States law enforcement system is one of the most complex in the world. There are three main legislative and enforcement levels of jurisdiction exist in this country - federal, regular and local. Each of these levels has different police structures for the application and protection of relevant laws. So historically there are many differences 
between different levels of jurisdiction in the names, as well as in the functions and powers of authority. The issue is even more complicated with the rapid increase in the number of private security and detective offices that perform many functions traditionally owned by the police. In turn, the statistical analysis conducted by the author shows that the types of jurisdictional authority of police forces of the United States are classified as: municipal police departments; departments of sheriffs and ordinary police departments in the counties; specialized police organizations such as the Police National Park (Rangers), port police, traffic police and police management in the areas of university campuses; Staff Police Departments.

\section{Purpose}

Based on the theory of Administrative law and analysis of legal acts, academic publications and other sources, the research is aimed at describing legal regulation of jurisdictional powers exercised by public administration authorities.

\section{Discussion of the main issues}

With regard to administrative jurisdiction in Ukraine, today the legal phenomenon is characterized by execution of the established powers in jurisdiction exercise, and at the same time, it is as an integral part of executive and regulatory activity of the relevant public executive authorities. So, Panova I. V. describes four main approaches to interpretation of administrative jurisdiction and suggests the fifth concept of the phenomenon. According to her definition, "being part, predominantly, of public executive bodies, including judicial ones and local authorities, administrative jurisdiction is of sub-law and law-enforcement nature in administrative jurisdictional proceedings established by law as: a) handling disputes; b) administrative law enforcement; c) execution of public coercive penalty; d) performing security, educational, and regulatory functions" [12, p. 47].

It should be noted that objectively, public administration is divided into two forms of enforcement: operative-executive and jurisdictional. Under the subjective criterion, two main approaches are distinguished in the theoretical interpretations of administrative jurisdiction, which can be conventionally labeled as "managerial" (narrow approach) and "multisubject" (broad approach). The "managerial" approach reduces administrative jurisdiction merely to the out of court activities of executive authorities. On the one 
hand, administrative jurisdiction can be described as activity established by the laws for the public authorities and officials to deal with administrative cases and impose respective administrative sanctions. On the other hand, it can be regarded as a set of cases within the competence of administrative agencies, unlike cases that fall within jurisdiction of courts. Also, the notion of administrative jurisdiction can be associated with a certain kind or type of executive and administrative efforts to resolve individual cases that are disputes in the field of public administration. This activity is carried out by implementing the relevant legal norms and require-ments through extra-judicial measures (administrative enforcement). Jurisdiction takes place when it comes to resolving disputes about rights. However, it should not be downgraded to jurisdiction only to settle disputes about rights, and the significance of this is that jurisdiction may be qualified as the actions of special authorities performing punitive administrative jurisdiction. Under the multidisciplinary approach administrative jurisdiction covers specific cases involving rights and obligations or legal interests of individuals and legal entities that the governing bodies consider. In this respect it is important to note that a number of legal scholars support a multisubject approach and refer administrative jurisdiction to as a totality of static and dynamic powers of a respective body. Bevzenko V.M. is certainly correct in defining jurisdiction in the administrative process as the procedure, regulated by the current legislation, to consider and resolve cases concerning citizens' complaints, administrative vio-lations and disciplinary misconduct of civil servants and by the authorized bodies. Actually, the concept of administrative justice, based on its philological content, means a certain management competence of a relevant authority [13, p. 42].

In this respect, Kolpakov V.K. is right to say that administrative jurisdiction is divided into administrative regulatory (i.e., positive activity), administrative judicial (i.e., resolution of public legal disputes) and administrative delictual, in other words that is, the competence to resolve cases of administrative offenses, for which administrative penalties are imposed [14, p. 257]. Having its roots in Administrative law the cited classification exists in the form of three codes: 1) Administrative Procedure code; 2) Code of Administrative Justice; 3) Code of Administrative Offenses. The validity of the approach is demonstrated by the fact that these three sources have long been the legal basis in EU member-states, unlike Ukraine, where the administrative procedure code has not yet been adopted. 
It is important to add that a type of administrative delictual proceedings is disciplinary proceedings. Particularly, the procedure of considering disciplinary cases contributes to an expeditious output in the cases and quick address to failures of civil servants as well as mobilization of the latter to do their work with high quality. To make an argument for the above, Kolpakov V.K. marks out administrative judicial proceedings, a component of administrative procedure, as the activity of public executive authorities aimed at resolving disputes between different entities, including administrative and disciplinary enforcement carried out in the administrative procedural manner [14, p. 284]. Furthermore, there are various approaches to the disciplinary proceedings. According to Bandurka O. M. and Tyshchenko M., disciplinary proceedings are a set of legal norms regulating social relations in law enforcement for imposing and executing disciplinary sanctions [15, p. 284]. Bahrrah D.M. believes that the division of the administrative procedure into the proceedings necessitates the formation of administrative procedure law institutions (disciplinary privatization proceedings institution) $[16$, p. 15].

In general, disciplinary liability is one of the types of legal liability. It is the duty of the person who violated the discipline to be responsible for his wrongful acts. Such person is subject to disciplinary penalties prescribed by law. The reason for bringing a civil servant to disciplinary liability is the commission of a disciplinary offense, which means the violation of discipline, wrongful guilty action or inaction, or a decision to be taken, consisting in the failure to perform or improper performance by the civil servant of his official duties, violation of the requirements established 8, 62 of the Law of Ukraine "On Civil Service". The direct manager of a civil servant has the right to file a petition to the head of the civil service to bring a civil servant to disciplinary responsibility for committing a disciplinary offense. The head of the civil service who, in accordance with the procedure established by the Law of Ukraine "On Civil Service", did not take measures to bring the civil servant subordinated to him to disciplinary responsibility for the committed disciplinary offenses, non did he submit any information regarding the commission of an administrative offense, corruption or related with corruption of an offense, a crime against an authority authorized to consider cases of such offenses, is liable in accordance with the law of Ukraine "On Civil services «. Disciplinary offenses are: 1) violation of the oath of a civil servant; 2) violation of the rules of ethical behavior of civil servants; 
3) disrespect for the state, state symbols of Ukraine, the Ukrainian people; 4) actions that harm the authority of the civil service; 5) failure or improper performance of official duties, acts of state authorities, orders (orders) and orders of directors, taken within the limits of their authority; 6) non-compliance with the rules of internal service regulations; 7) exceeding of official authority, if it does not contain the composition of a crime or an administrative offense; 8) non-compliance with the requirements of political impartiality of a civil servant; 9) use of powers in the private interests or in the unlawful personal interests of other persons; 10) submission of inaccurate information about the circumstances that impede the realization of the right to the civil service during the entry into the civil service, as well as failure to provide necessary information about such circumstances that arose during the service; 11) failure to report to the head of the civil service on the occurrence of relations of direct subordination between a civil servant and his or her relatives within 15 days from the date of their occurrence; 12) absenteeism of the civil servant (including lack of service for more than three hours during the working day) without good reason; 13) the appearance of a civil servant in service in a state of drunkenness, in a state of narcotic or toxic intoxication; 14) the acceptance by an official of an unreasonable decision that caused the violation of the integrity of the state or communal property, their illegal use or other damage to state or communal property, if such actions do not include a crime or an administrative offense.

A civil servant can not be brought to disciplinary responsibility: if 6 months have elapsed since the day when the head of the civil service learned or should have learned about the commission of a disciplinary offense, not taking into account time of temporary incapacity of a civil servant or his stay on a holiday; if one year has passed since its commission.

Taking about account the provisions of the Law of Ukraine "On Civil Service", the procedure for bringing a civil servant to disciplinary liability has the following mandatory stages: 1) initiation of disciplinary proceedings by the subject of appointment (part 1 Article 68); 2) formation of a disciplinary commission disciplinary case, in accordance with the requirements of Part 2 of Article 73; 3) consideration of the properly disciplined case at the meeting of the disciplinary commission and making, following the results of this consideration, the proposals of the Commission on the issues of the higher civil service or submission of the disciplinary commission to the subject of appointment (Part 9, Article 10, Article 69 ); 4) 
consideration of a disciplinary case by the subject of the appointment taking into account the proposal of the Commission or submission to the disciplinary commission within 10 calendar days from the day of receipt of the submission, which must include the removal of a written explanation from a public servant or recording the fact of refusal to provide such an explanation (Part 11 Article 69, Article 75, Part 5, Article 77); 5) acceptance by the subject of the appointment of the reasoned decision on the results of consideration of the proposal of the Commission or filing a disciplinary commission and disciplinary case (Part 1, 2, Article 77) [17].

Please note that the service discipline in a state body is based on the following principles: diligent and professional performance of the civil servant's duties; creation of proper conditions for effective work, their logistical support; promotion by results of work.

To sum up, theoretical research is expedient and makes it possible to examine disciplinary proceedings, regardless of the sphere of the relevant legal relations, as a structural element of the administrative and delictual procedure, and to classify it as a kind of administrative jurisdiction of the public administration authorities to exercise their jurisdictional powers.

\section{Findings}

However, it is worth noting that the classification of the public administration authorities vested with jurisdictional powers is diverse. So, concerning the public administration bodies which jurisdictional powers depend on the kind of proceedings, then the following classification can be proposed: 1) handling applications of citizens and providing administrative services by public administration bodies, in particular public authorities, local self-government, their officials, heads and officials of enterprises, institutions, organizations irrespectively of the forms of ownership, citizens' associations entrusted to consider applications (complaints), and administrative service centers (in accordance with Article 1 of the Law of Ukraine "On Administrative Services"); 2) administrative and delictual proceedings where the legal status of the parties is regulated by Article 213 of the Code of Ukraine "On Administrative Offenses" and relevant provisions of the CUPA; and 3) administrative and delictual pro-ceedings, where the executive authorities empowered with settling disputes between different entities and imposing disciplinary sanctions in administrative procedural manner, are regulated by the disciplinary stat- 
utes, regulations, provisions of the Labor Code of Ukraine and the law of Ukraine "On Public Service"; and 4) administrative judicial jurisdiction refers to the competence of administrative courts to try relevant cases (Article 19 of the Administrative Proceedings Code of Ukraine).

It should be added that certain principles are also characteristic of administrative jurisdiction. In this context, there is a sign that each principle must meet:

1) principles are always a normative and guiding basis, that is, enshrined in the norms of law [18, p. 23]. If they are not enshrined in legal norms, they are not the principles of law, since they are not legal, but remain political or supervisory, in connection with which they do not and can not perform the tasks entrusted to the administrative-procedural principles in the law and proceedings, in particular;

2) only those normative and guiding fundamental ideas that envisage the most general and important aspects of the jurisdiction of the inspection body, which directly determine its character, content and orientation, can be considered as one of the principles. They characterize the nature of this activity in general, all its parties and institutions. There can be no general attitude to the principles of the right to completeness and speed of the chosen measure of influence, immediate response to the offense, freedom of appeal, as it is - functional duties, subjective rights and general provisions of the law;

3 ) the principles of administrative and jurisdictional activity should proceed from the general principles of law, and also be appropriately correlated with the principles of administrative law, criminal procedure and civil procedural law;

4) the concept of the principles of proceedings conducted by officials of the inspection body, provides for their interconnection and mutual conditionality.

All procedural principles are closely linked. To identify their features, they can be grouped by type: 1) depending on the nature of the normative acts, in which their content is expressed on:- constitutional; - are enshrined in other normative-legal acts; 2) depending on the subject of regulation on: - organizational; - functional; 3 ) depending on their actions in the system of law: - general legal; - interbranch; - industry.

Add that also highlight the system-wide principles of administrative and jurisdictional activity, include the following: - legality; - priority of human 
and civil rights and freedoms; - individuality;- a combination of interests of citizens and the state; - objectivity, combination of publicity and professional secrecy; - publicity; - independence and independence in decision making, e.t.c.

With regard to the latter, we can note the following, that the fundamental principle of administrative jurisdiction is, of course, the legality which provides for and is embodied in the strict implementation, observance of legal norms (material and procedural) by all subjects of administrative proceedings, regardless of whether it is a question of the competent authorities, or about individuals or legal entities.

The principle of objectivity is aimed at the most complete exclusion from the administrative activities of manifestations of subjectivity, one-sidedness and bias on the part of officials as the central apparatus and territorial bodies. Also, the principle of objectivity should be considered obligatory for all authorized officials to deeply and thoroughly explore all the circumstances that determine those or other variants of their behavior and decisions in the process of administrative and jurisdictional activity.

The essence of the principle of humanism is respect for the dignity and rights of the individual. Such a requirement is addressed to everyone around this entity of law. Since this principle reflects the relationship between a person and a society, it is natural that the ideas of humanism are embodied in the content of the basic ideas of the laws of social management.

The principle of the combination of publicity and professional secrecy should ensure open consideration of administrative cases, the right to publicize the course and outcome of the case, the content of the decision adopted on it.

The principle of justice is based on the formally-determined in the rules of law the arguments about equity in various life circumstances. The main guarantor of the affirmation of justice and the elimination of the unfair treatment is the implementation of a full-fledged jurisdictional proceeding, which corresponds to the letter of the law.

Justice is a prerequisite for jurisdictional proceedings, as well, because without the determination of the object of control, the law-enforcement act will not be fair. Legal regulation is subject to the volitional behavior of the subject. Therefore, without ascertaining the will, which is the most significant for law enforcement, it is impossible to assert with certainty that the situation is fully in line with the requirements of procedural law. 


\section{Jurisdictional powers of public administration authorities in Ukraine...}

The principle of independence and independence in decision-making is closely interlinked with the principle of justice. The essence of the principle above all is that any interference of other state bodies and their officials in administrative and jurisdictional activities.

Of importance is the principle of equality of the parties, which in practice provides for the unimpeded opportunity for each party to participate in all stages of consideration of an individual case. Important is not only the provisions of Article 24 of the Constitution of Ukraine, which stipulates that citizens of Ukraine have equal constitutional rights and freedoms and are equal before the law. Every individual and any legal entity must be recognized as equal and they must be given a real opportunity to truly exercise their rights. The complainant is a citizen exercising his constitutional right, which corresponds to the constitutional duty imposed on certain officials, from which, in turn, depends on the adoption of the appropriate decision on this complaint or the reasoned deviation of it. The principle of equality before the law is that there can be no privileges or restrictions based on race, color, political, religious or other beliefs, sex, ethnic or social origin, property status, place of residence, language or other grounds [19].

The principle of protecting the interests of the state and the individual means the necessity of proper use by the parties of the administrative and jurisdictional process of their rights, taking into account the interests of the state, ensuring the implementation of guarantees of rights and legitimate interests of the person. Thus, the interests of an individual citizen can not be recognized solely as a priority for other citizens taken together (as citizens of the country as a whole). At the same time, modern political and legal thought continues to focus on the extent to which the rights and freedoms of an individual can be of decisive importance, may be sufficient reason for them, for example, to justify (temporary, for example) restriction.

Finally, administrative jurisdiction is characterized by certain features: 1 . authority of public bodies and their officials to carry out their public administration functions in accordance with the current legislation in order to resolve legal disputes, to apply coercive penalties, to restore the rights violated, and to make decisions in individual administrative cases. 2. presence of a legal dispute, a dispute about a right, violation of the established legal norms, individual administrative cases, disputable interest, which are considered administratively, i.e., out of court. 3. proper, full and comprehensive procedural regulation of the activities of public authorities, parties and all concerned, as 
well as conditions for competition in the decision-making and establishment of special procedural forms binding on jurisdiction. For example, it is compulsory to draft a protocol, an act, and other procedural documents or appeal to a court in accordance with the procedure established by law. 4. obligation to take proper decisions or undertake appropriate legal acts for applying law to a particular case, in other words to consider a dispute about a right, a legal dispute or an individual administrative matter in fact. For example, it includes issuance of a certificate of registration, an administrative penalty order, or a decision to impose coercive penalty, etc. [20, p. 74].

\section{Conclusions}

All things considered are evident that it is a matter of priority to introduce effective administrative jurisdiction under current administrative and judicial reforms in Ukraine. Refocusing of government policy on the human being as the highest social value necessitates strengthening the protection of human rights against possible arbitrariness of the authorities. It should be achieved by means of: further development of specialized justice for more effective implementation of the provisions on fair trial rights of the Constitution of Ukraine and the Convention on the Protection of Human Rights and Fundamental Freedoms; eliminating groundless obstacles and restrictions on access to justice and simplifying the judicial procedure, increase of availability of legal aid to all citizens; acceleration of the case processing; and implementation of the certainty principle in legal relations; reinforcement of the independence of judges as well as the role of the judiciary in the state system.

Finally, the concept of administrative jurisdiction is considered from different points of view, provided in some legislative acts or studied by administrative law experts in relation to the role of those who are authorized to perform public administration jurisdiction. A key role is played by those who implement jurisdictional powers. They must act within law boundaries and in compliance with law to ensure effective protection of human rights and citizens. Thus, it should be noted that administrative jurisdiction is a totality of statutory provisions of public administration powers, including jurisdictional powers to deal with citizens' applications, to the relevant authority determined by the administrative acts, following the administrative procedural; individual administrative cases where administrative (disciplinary) coercion is imposed. 


\section{Jurisdictional powers of public administration authorities in Ukraine...}

\section{References:}

1. Yastremska O. M. (2015) Publichne administruvannia [Public administration]. Kharkov.: KhNEU them. S. Kuznets (in Ukrainian)

2. Yurydycheskyi entsyklopedycheskyi slovar (1984) [Encyclopedic dictionary], Moskow: Soviet Encyclopedia.

3. Bolshaia sovetskaia эntsyklopedyia (1957) [The Great Soviet Encyclopedia], Moskow.

4. Pylypenko A. (2004) Administratyvno-iurysdyktsiina diialnist orhaniv vykonavchoi vlady: pytannia teorii [The administrative and legal department of the authorities of the Wikonavia authorities: the drinking of theories]. The Law of Ukraine, vol. 2, no 2, pp. 26-31.

5. Yu. M. Kozlov, L. L. Popov (1999) Admynystratyvnoe pravo [Administrative Law]. Moskow (in Russian)

6. Slovar admynystratyvnoho prava (1999) [Dictionary of Administrative Law], Moskow: The Legal Culture Foundation.

7. Anokhina L.S. (2006) Administratyvna yurysdyktsiia: poniattia, sutnist, zmist [Administrative jurisdiction: concept, essence, content] Scientific Notes of the series "Legal Sciences", Kherson: Taurian National University named after V.I. Vernadsky, pp. 172-175.

8. Pedko Yu. (2001) Administratyvna yustytsiia i administratyvna yurysdyktsiia: deiaki teoretychni ta praktychni pytannia spivvidnoshennia [Administrative Justice and Administrative Jurisdiction: Some Theoretical and Practical Questions of Relationship]. The Law of Ukraine, vol. 10, no 10, pp. 72-75.

9. Aver'ianov V.B. (1997) Pytannia administratyvnoi reformy u zmisti. Zahalnoi kontseptsii derzhavno-pravovoi reformy [The issue of administrative reform in content. The general concept of state-legal reform], Kyiv: State-legal reform in Ukraine, pp. 193-195.

10. A.P. Korenev (1997) Admynystratyvnaia deiatelnost orhanov vnutrennykh del [Administrative activity of the bodies of the internal affairs]. Moscow: Legal Institute of the Ministry of Internal Affairs of Russia (in Russian)

11. Yunin O.S. (2013) Osoblyvosti administratyvnoi diialnosti politsii Velykobrytanii ta Frantsii [Features of the administrative activities of the UK and France police]. Bulletin of the Academy of Labor and Social Relations of the Federation of Trade Unions of Ukraine. Series "Law and Public Administration", vol. 1, no 1, pp. 143-147.

12. Panova Y.V. (2001) Admynystratyvno-protsessualnaia deiatelnost v Rossyiskoi Federatsyy [Administrative and procedural activities in the Russian Federation]. Saratov (in Russian)

13. A. T. Komziuk, V. M. Bevzenko, R. S. Melnyk (2007) Administratyvnyi protses Ukrainy [Administrative processes in Ukraine] - Kyiv: Precedent (in Ukrainian)

14. Kolpakov V. K. (2003) Administratyvna yurysdyktsiia: sutnist poniatt ia [Administrative jurisdiction: the essence of the understanding]. Power and Law: $\mathrm{zb}$. sciences, vol. 19, no 19, pp. 256-258.

15. Tyshchenko N.M. (1998) Admynystratyvno-protsesualnui status hrazhdanyna Ukraynы: problemы teoryy y puty sovershenstvovanyia [The administrative 
and procedural status of a citizen of Ukraine: problems of theory and ways of improvement]. Kharkov (in Ukrainian)

16. Bakhrakh D. N. (1989) Proyzvodstvo po delam ob admynystratyvnykh pravonarushenyiakh (Posobye dlia slushatelei narodnokh unyversytetov) [Production in cases of administrative offenses (Manual for students of national universities)]. Moskow: Knowledge (in Russian)

17. Zakon Ukrainy pro derzhavnu sluzhbu (1993) [On the Civil Service: The Law of Ukraine]

18. Nakaz Minahropolityky ta prodovolstva Ukrainy pro zatverdzhennia Polozhennia pro kolehiiu Ministerstva ahrarnoi polityky ta prodovolstva Ukrainy (2011) [On Approval of the Regulation on the Collegium of the Ministry of Agrarian Policy and Food of Ukraine: Order of the Ministry of Agrarian Policy and Food of Ukraine]

19. Aver'ianov V. (2003) Reformuvannia ukrainskoho administratyvnoho prava: gruntovnyi pryvid dlia teoretychnoi dyskusii [Reform of the Ukrainian administrative law: a thorough ground for theoretical discussion]. The Law of Ukraine, vol. 5, no 5, pp. 23.

20. Demskyi E. F. (2008) Administratyvno protsesualne pravo Ukrainy [Administically procedural law of Ukraine]. Kyiv: Urincom Inter (in Ukrainian) 
History of credit legal relationship in Ukraine and its regulation in foreign...

HISTORY OF CREDIT LEGAL RELATIONSHIP IN UKRAINE AND ITS REGULATION IN FOREIGN JURISDICTIONS

\section{Tupitska Yevgenia ${ }^{1}$ \\ Tymoshevska Iryna ${ }^{2}$}

DOI: http://dx.doi.org/10.30525/978-9934-571-29-9_11

Abstract. The article is devoted to the genesis of credit legal relationship as the notion in Civil law as well as historical transformations of its legal regulation at the different stages of Ukraine's development. The analysis deals compliance of Ukrainian laws with international crediting standards. The theoretical and practical recommendations on the improvement of law implementation and legal credit regulation are made. The article argues that the domestic legislation regulates the relations of consumer lending are more perfect in the field of consumer rights protection in comparison with other countries of the post-Soviet area. As for the EU countries, the legal regulation and practical application of the credit institution used by the participants in civilian circulation to meet their economic needs is deprived of those gaps existing in the domestic legal system. In particular, it is a question of the uncertainty in the Ukrainian legislation of issues related to the use of misleading advertising by banks concerning lending conditions, incomplete disclosure of information, difficulties encountered in assessing the borrower's creditworthiness, the status of a credit intermediary, establishing unfair terms of consumer credit agreements, imposing by banks and other institutions of additional and related services, lack of equal requirements to creditors, etc. The authors conclude that the change in the political and economic situation in our country directly influenced the legislator's approach to the legal regulation of credit relations. The transition of social relations to the market economy has led to increased acquisition by the subjects of the civilian turnover of goods and services on credit. However, the current legal credit regulation does not always meet the requirements of

\footnotetext{
${ }^{1}$ Candidate of Law Sciences,

Assistant Professor at Department No. 2 of Civil Law,

Yaroslav Mudryi National Law University, Ukraine

${ }^{2}$ Candidate of Law Sciences,

Assistant of the Department No. 2 of Civil Law,

Yaroslav Mudryi National Law University, Ukraine

(C) Tupitska Yevgenia, Tymoshevska Iryna
} 
practice. To date, Ukrainian legislation has legal acts that regulate lending relations, while in the EU countries, credit agreements have been regulated at the level of separate legislative acts since the previous century. Therefore, the foreign practice of the separate credit institution has already deprived of those gaps that Ukrainian legal system still need to fill up. In order to eliminate the problems of legal consumer credit regulation it is necessary to bring the legislation of Ukraine into conformity with the best international practice.

\section{Introduction}

Economy of the developed countries is characterized by the domination of credit relationships. Embracing the total system of social reproduction, including production, distribution, exchange and consumption, they have penetrated deeply into international economic relations. The proper legal regulation of debt liabilities and the financial and credit system on the whole is a guarantee of the stability of the market economy as well as commodity-money circulation of any developed country in the world. Today there is a rapid development of lending, its volume increase and distribution in society. The said factors require a comprehensive research of the genesis of credit legal relations in Ukraine and the development of scientific recommendations for the improvement of domestic legislation in this area. The development of legal credit regulation in Ukraine is an integral part of the world historical transformation of credit relations; therefore, it is logical to begin studying the issue under discussion with the origin of this legal institution in the world ancient systems.

\section{The genesis of credit relations in recent times}

A prerequisite for the development of credit relations in their modern legal sense can be considered the origin of borrowing relations (mutuum) in Roman private law. Banks currently engaged in providing financial services did not initially perform such functions. For example, it is known that in ancient Rome there were argentarii, i.e. a union of trading owners who set off mutual debt liabilities between customers and kept records of deposits and cash provided on loan [1, p. 408]. The transformation of banks directly into lending institutions dates back to the Middle Ages, in particular to the opening of the Amsterdam Bank in 1609. Consequently a real and unilateral loan agreement no longer met the purpose of banking service 
to administer credit relations. It resulted in development of a complicated bilateral obligation, which involves not only the borrower's obligation to return the loan amount, but also the obligation of the bank to grant a loan. G. Dernburg commented thereupon, "loans are often preceded by contracts for loan transfer - pacta de mutuo dando and pacta de mutuo accipiendo. Both transactions are usually united in the one, but each of them has its own peculiarities. Pactum de mutuo dando - a contract for the transfer of things on loan - is based on the silently acknowledged condition that a borrower must be creditworthy when receiving it. Thus, this condition was provided for by the contractor, who promised to conclude a loan agreement, since the latter intended to grant a money loan, rather than lose it at all" [2, p. 277].

As for the promise of loan issuing, it should be noted that this transaction was eventually transformed into a loan agreement. The credit opening (sui generic), in the narrow sense of the word, is a promise to transfer, upon request and at the disposal of the counterparty, the funds specified in the agreement. So, the credit opening should be considered as an agreement on the implementation of a loan in the future, or a grant of loan on the specified terms [1, p. 449].

Over time, in 1922 the Central Committee of the Ukrainian SSR adopted Article 218 stipulating a preliminary loan agreement. The credit reform of 1930-1931 led to introduction of the concept of a credit contract as an independent transaction in the civilian turnover, which differed from the loan agreement. Thus, Article 382 of the Central Committee of the Ukrainian SSR (hereinafter referred to as CC, USSR), 1964 regulated the lending to state organizations, collective farms and other cooperative and public organizations. This activity was carried out in accordance with the approved plans and by issuing purpose term loans by the State Bank of the USSR and other banks of the USSR as provided for by the legislation of the USSR. And in this, mutual lending to organizations in kind or in cash, including the issuance of advances, was allowed only in cases established by the legislation of the USSR. The conditions and procedure for lending by one collective farm of another for providing production assistance were authorized by the Council of Ministers of the Ukrainian SSR.

As we see, not excluding entirely the construction of a loan agreement for regulating credit relations, the legislation of the Soviet period compiled the disposition of Independent legal institutions, Art. 382, CC, USSR, 1964. As for lending to individuals, the relevant relations were regulated by Bank 
loans to citizens, Art. 383, CC, USSR, 1964 with a reference provision prescribing that loans granted to citizens are issued by banks of the USSR in compliance with the laws of the Union of Soviet Socialist Republics.

Significant changes in the development of the legal regulation of credit relations was significantly changed due to the adoption of [3] the Fundamentals of Civil legislation of the USSR and the republics [4]. Accordingly, Art. 113 of the Fundamentals stated that under the loan agreement (credit contract), the lender (creditor) transfers possession of money or things determined by generic features (full economic management or operational management) to the borrower (debtor), and the latter undertakes to return the same amount of money or the same number of things of the same kind and the same quality in due time.

In the case of business loan the interest was charged as agreed upon by the parties. In the absence of the agreement, it was determined by the average interest rate of the bank at the location of the creditor. The loan to individuals was interest-free. All of this points to the fact that the terms of loan and credit were used as synonyms in the Soviet period. Over time, however, the independent legal nature of the credit contract and its distinction from the loan agreement has been increasingly supported in scientific legal publications. In particular, there are the following distinctive features of a credit contract: a special entity; the presumption of payment of credit services; the moment of occurrence of the parties' rights and obligations under the contract. Furthermore, a credit contract does not lose its generic relation to a loan agreement that allows of applying the general provisions on the loan agreement to the credit relations. Gradually, the approach was implemented for drafting the relevant chapters of the Civil Code of Ukraine in 2004 [5]. In this regard, it seems logical that Chapter 71 lacks for provisions on financial services.

Also, the Soviet period can be marked by the development of consumer lending [6]. The vast majority of loans were granted directly in kind owing to the instable financial system. The payment by installment for the purchase of housing was a common practice. One of the most common types of consumer lending was the sale and purchase of durable goods under the payment by installment. By contracting, citizens acquired household items, professional devices, agricultural equipment, and houses, cooperative and small enterprises.

Consumer cooperatives played a significant role in satisfying the lending needs of the population. There were two types of credit: small and long- 
term ones. Small consumer credit was granted for the purchase of food products and necessities, for a period not exceeding one month and at a rate not exceeding fifty percent of the salary. The responsibility for timely repayment of credit indebtedness was relied on the administration of the enterprise under the relevant agreement with the consumer cooperative. Accordingly, the debt repayment was at the expense of payments deducted from the borrower's wages and transferred to the consumer cooperative. Long-term credit was intended for persons who had shares in consumer cooperatives. At the expense of their funds, individuals satisfied their needs in consumer goods and household goods. Long-term consumer credits were issued by banks as well as by state-owned industrial enterprises. The latter provided a credit in commodity. The credit amount did not exceed one and a half months' earnings and six months of the repayment term [7].

The cash credit was not common in the socialist period. In fact, the funds were granted for the construction and major repairs of individual dwellings, houses, cottages and improvement of individual holdings, for the purchase of livestock, etc. Banks lent at the expense of their available credit resources. It is important that the size of credits was approved in the annual long-term lending plans by the Council of Ministers of the USSR. However, the main resource of bank consumer lending was the return of previously granted credits. Accordingly, the Council plans provided for the terms and amounts of credit repayments.

As we noted, the classic contractual loan scheme was used for the legal registration of consumer loan in Soviet times. Banks, mutual funds and pawn shops act as the lender in this agreement. For example, if a citizen want to buy a certain product on the basis of a sale contract, he was entitled to pay part of his value by cash, and the rest of the debt could be converted into a loan obligation. Thus, the sale agreement changed to the loan agreement. This transformation arose as a result of the absence of the design of a loan agreement in the text of the Civil Code of the Ukrainian SSR in 1922. Individuals had the opportunity to conclude a preliminary loan agreement, the terms of such contract were considered legal keeping the written form, regardless the amount of money. At the same time, the lender had the right to request the cancellation of the prelimiary contract, if the property situation of the counterparty will significantly deteriorate in the future, in particular, if become insolvent, or will stop paying. In the latter case it was assumed that the creditor is entitled to charge interest on interest (so-called compound interest). 
In the sixties of the XX century, with the adoption of the Decree of the Council of Ministers of the USSR "On the sale of durable goods to employees and servants on credit", consumer credit relations became more poular. It was given the opportunity to define a special list of goods for sale on credit, that, in turn, could be changed or supplemented by other durable goods available in sufficient assortment. When a product was selling on credit, at least twenty percent of the purchase price was paid by the buyer by cash, the rest, as a rule, was repaid from six to twelve months. At the same time the loan charge (amounting to one - two percent of the retail value of the goods) was paid by buyers in favor of trading companies. In order to simplify settlements, repayment of the granted loan was carried out by means of retention of funds from the salary of the employee or servant at the place of their main work and its corresponding inclusion in accounts of trade organizations.

In addition to the sale of durable goods for loans in the Soviet period, there were other forms of consumer lending. For example, loans to citizens were provided for participation in housing and building cooperatives (Decree of the Council of Ministers of the Ukrainian SSR "On housing construction and cottage construction cooperatives", "On housing construction cooperation", the Decree of the Central Committee of the Communist Party of Ukraine and the Council of Ministers of the Ukrainian SSR "On Individual and cooperative housing construction"), for purchasing the livestock, the development of a household in the case of a resettlement in the less populated regions of the country (Ordinance of the Presidium of the Verhovna Rada of the USSR "On the Measures to Strengthen the State Aid to Families with a Child «), for purchasing, repairing and reconstruction of houses that are empty, for the development of self-employment, for the construction of individual houses and so on.

It should be noted that consumer lending by banks was of a slightly different nature, since they rarely independently issued loans to citizens. There were always three parties where intermediaries were trade organizations, collective farms, state agricultural enterprises, and others. Savings banks were authorized to issue credits to citizens at the expense of available deposits. Nevertheless, under their agreements, the borrower did not obtain the funds in cash, but in the check of standard sample, that entitled the consumer to buy goods allowed for sale on credit within the credit limits. 


\section{Legal regulation of credit relations in modern Ukraine}

As a result of independence of Ukraine and its transition to the market economy along with reforming of the banking system legal regulation of lending relations have undergone radical changes. At present, Ukraine has a developed banking system, including the National Bank of Ukraine; other banks (residents and non-residents, registered in accordance with the law of Ukraine); non-bank financial institutions exclusively authorized to accept deposits, make loans or keep customer accounts; Deposit Guarantee Fund; banking infrastructure, as well as relationships and agreements between them. It was the law of the USSR on banks and banking, 1991 that launched legislative support for the functioning of the Ukrainian banking system, although commercial banking institutions at the territory of Ukraine had operated even before that.

The essential point is that the Ukrainian legislation, in comparison with other post-Soviet countries, is characterized by regulation and development of the relations at issue. In particular, credit relations are regulated by the provisions of the Civil Code of Ukraine [5] and the Laws of Ukraine "On Banks and Banking", "On Credit Unions", "On Financial Services and State Regulation of Financial Services Markets" [8], and "On Protection of Consumer Rights" [9], by the resolutions of the National Bank of Ukraine "On Approval of the Rules of Providing by Banks of Ukraine Information to the Consumer on the Conditions of Credit and Total Credit Value", to name a few. A special achievement of domestic legislation is the Law of Ukraine on Consumer Lending, November 15, 2016 [10] aimed at establishing a mechanism of protecting the rights and legitimate interests of the participants in the relevant relations, creating proper competitive environment at the financial market, increasing the level of public confidence in it, and providing favorable conditions for the development of Ukrainian economy. This means that Ukraine is attempting to bring national legislation on consumer lending in line with the provisions of European law and consolidate the effective mechanism of protecting the rights of the borrower as the weaker party in these contractual relations.

\section{Legal regulation of credit relations in foreign countries}

The formation and development of legal science in Ukraine is integral and essential part of the world experience in the establishment of the rule of law. Today, there is an objective tendency for international cooperation to 
intensify and deepen in economic, political, cultural and other spheres. This necessitates mutual study of the experience of legal credit relations regulation taking into account the peculiarities of social development in certain states. In this regard, it is considered necessary to analyze the procedure of consumer credit regulation in the legislation and law practice of foreign jurisdictions.

First of all, it should be emphasized that at the current stage of the legislation development the world leading states have already regulated the lending relations by separate normative legal acts on credit for several decades. So, the Council of Europe adopted the resolution on Preliminary program of the European Economic Community for a consumer protection and information policy in 1975. This document inaugurates the priority of economic consumer interests on the principles of their protection against unfair contract terms and losses arising as a result of improper services. The resolution also stipulates that presentation of goods and services, including financial ones, and methods of their selling should not mislead, directly or indirectly, the persons to whom they are offered.

In 1987, the special EU directive on consumer credit came into force, which sets requirements for the content of the credit agreement. So, in order to protect the rights of participants in these relationships, the contract must contain conditions for the actual amount of interest per annum, the conditions for their change, the terms of the amount, the number and frequency of payments, other costs that may be incurred in connection with the conclusion and performance of the contract, the information on the total amount of all specified payments, the terms of the elements of expenditure not taken into account when calculating the actual annual percentage, but subject to compensation by the consumer in the event of certain circumstances, and a list of such circumstances. Annex 1 of the Directive details the standard terms of various credit contracts as recommended for application in the national legislation of the EU Member States. For example, the indispensible terms of a credit contract concluded for acquiring goods and services are: the description of the goods and services being the subject matter, the price, the amount of the first payment, the total cost of the credit, number, frequency and amount of subsequent payments, indications that entitle the consumer to discharge the obligations before the date of expiry and therefore, obtain a proportional reduction in the cost of the credit, the name of the person who posses the goods, on the conditions and the term when 
the consumer becomes the owner of the goods, the detailed methods of securing the credit obligation, the time limits for the consumer's withdrawal of the contract, etc. The overdraft credit agreements must also specify the maximum amount of the credit or the procedure for its determining, the conditions for its using and repayment, the time limits for the agreement withdrawal, etc. The Directive focuses on credit agreements aimed at purchasing goods, works and services by consumers. The detail regulation is provided for the case when the consumer obtains a credit under a pre-existing agreement between the creditor and the seller (supplier) of the goods (services) that prescribes granting credits to the consumers of the specified seller (supplier) in order to acquire the goods (services) of the latter. If the contractual goods (services) are not supplied to the consumer or their quantity or quality is not in compliance the contract terms, the consumer is entitled to apply to the creditor for redress (Article 11 of the Directive) [11].

Subsequently, many EU member states have implemented the Directive in national legislation by adopting special laws or amendments to the current regulations. Nevertheless, it should be noted that to date, the consumer lending market in most European states has some pronounced domestic peculiarities owing to the national lending culture.

A pan-European feature of the consumer credit regulation is that special legal acts embrace contractual obligations under mortgage credits. Moreover, it is common practice to formulate so-called general conditions of the contract, which become the key instrument for regulating the consumer services supplied by both financial institutions and non-financial organizations. The EU Directive and national laws set forth the requirements for the "general conditions".

The theory of general credit conditions dominates mostly in Germany, where the relevant law (Allgemeine Geschäftsbedingungen der Banken) was adopted in 1974. The law contributed to generalizing the established court practice of resolving credit-related disputes as well as established the standard wording of void contract terms. It is the Federal Union of German Banks, a non-profit organization uniting various credit institutions that develops general conditions of credit agreements in Germany. Most German banks apply the general conditions as their own local legal acts.

Consumer loan relations in Germany are regulated by the Law "On General Terms and Conditions of Credit Agreements", by the Civil Code, the Law "On Consumer Lending," as well as by the Special Law "On the 


\section{Tupitska Yevgenia, Tymoshevska Iryna}

reneging on a deal "in front of the Entrance Door". Let consider these legal acts in more detail.

The Law "On Consumer Lending" was adopted in Germany in 1990 and contains rules on bank lending, on contracts with a clause on payment installments, on contracts aimed at financing production, sales of goods, provision of services, employment contracts. Paragraph 3 of the specified normative act carries out a special distinction - establishhes the types of credit or intermediary agreements (concluded during consumer lending), and the cases when its provisions apply. At the same time, it is noted that the provisions of the Law "On Consumer Lending" have priority over other legal acts regulating the mentioned relations. The Law defines an agreement on consumer lending as an agreement under which a business entity (the creditor) provides or undertakes to provide a consumer (a borrower) with a payable credit in the form of a loan, it include an arrangement for the installments of the payment or other financial assistance. At the same time, the law establishes a minimum amount of consumer lending. So, if a loan is provided for less than $€ 200$, it is not considered as consumer loan. Also, contractual relationship between worker and employer couldn't be considered as consumer credit relations, if the interest rate for such loan is less than adopted in the market turnover. The contract concluded within the framework of housing construction, carried out on the basis of public-law decisions on the allocation or on the basis of a budget subsidy also couldn't be considered as consumer loan relations, if the contract is concluded directly between the consumer and a public entity allocating construction costs with an interest rate less than adopted in the market turnover. The law regulates in detail the issues related to the execution of an application for a loan, the liability of the borrower for late payment, the order of execution and the order of debt repayment, the procedure for termination of the loan agreement, etc. Also German law establish the concept of an agreement on credit intermediation, whereby a special person - a credit intermediary (for a fee) takes appropriate actions from mediation in the interests of the consumer or is looking for the possibility of concluding a loan agreement.

Sufficiently useful for the regulation of Ukrainian property turnover are the rules established in German legislation on "interrelated transactions". In accordance with paragraph 9 of the German Law "On Consumer Lending", if goods (works, services) are acquired at the expense of credit funds, the relevant contract (sale contract, etc.) together with the loan agreement form 
the interrelated transaction, therefore, such transactions should be considered as a whole, in their economic unity. The expression of the consumer's willingness aimed at concluding such an interrelated transaction that becomes effective only if the consumer does not declare the refusal from it, in accordance with the established procedure. If, at the time of the consumer's refusal, the amount of the loan has already been transferred to the seller (the performer of works and services), in the relations with the consumer (in terms of the legal consequences of such refusal), the creditor enters into the rights and obligations of the seller (executor) under the relevant agreement.

Exploring the concept of interrelated transactions in German law, we should pay attention to the provisions of the Law "Reneging on a Deal" on 1986 , that regulate issues relating to the protection of consumers' interests against a possible kind of damage arising in the so-called "direct trade". These are cases where the client is not well-informed about the quality and other characteristics of the goods or services offered to him. In this connection, the consumer may not always correctly decide on the appropriateness of acquiring the corresponding goods (works, services), to establish correctly whether they meet his real requirements or not. For example, in the case of purchasing a product in the catalog, the consumer often has no opportunity to compare its quality and price with the similar characteristics of other goods of this type or doesn't aware the risks associated with the purchase of such goods. Thus, the consumer has the right to refuse to repay the loan (transferred to the seller in order to pay for the purchased goods) in the presence of circumstances that give him the right to refuse the fulfillment of the obligation arising from the sale contract.

In German law enforcement practice there is a problem of competition between the norms of the Law "On Consumer Loans" and the Law "Reneging on a Deal". In short, it is decided by such a rule: if in a specific situation the provisions of the Law "On Consumer Credit" should be applied, then in accordance with part 2 of paragraph 5 of the Law "On waiving of transactions" the provisions of the latter shouldn't be applied.

Having significant features of legal credit agreements regulation English law differs from respective legal acts in other jurisdictions. The law of 1974 thoroughly and sufficiently regulates every detail of a credit transaction. To take an illustration, it stipulates the title of the document, the print size, the degree of contrast between the print and the paper on which a contract is printed. In accordance with English law, a credit agreement must 
contain the conditions of the total credit amount, annual interest rate, credit repayment schedule, etc. Moreover, the specified items cannot be "mixed" with others, but should be located next to the document field intended for its signature by the debtor. In certain cases violations by the creditor of the legal requirements for the form and content of the contract entails the inability to enforce the credit agreement.

In English law, the rights and obligations of the parties to the loan agreement are regulated in detail. An essential condition is the obligation of the creditor to provide the borrower with information related to obtaining a loan and the fulfillment of the terms of this transaction. The law states that the creditor must inform the borrower within seven days from the moment of his claim about the credit agencies he has addressed in order to obtain information about the borrower. In this case, the borrower also has the right to obtain a copy of the file with information that has been transferred to its future lender from the relevant reference credit agency. Due to the fact that the borrower has the right to return the received loan ahead of schedule, the creditor has the obligation to provide information on the amount of loan debt within twelve days. In case of delay by the debtor of repayment of a credit obligation, the creditor should request a payment of the debt to the borrower, and the latter has the right to fulfill its obligation within seven days.

It is worth paying attention to the provisions of English law that prohibit the inclusion in the text of the loan agreement the deliberately bonded (for the debtor) conditions. For example, in accordance with the 1974 Act, a loan agreement may be declared void as imposing a person in an extremely disadvantageous position if it is proved that the loan payment, established by the contract, is too large or if the loan agreement contains other conditions that contradict the notion of "honest trade".

The essential thing about the law of United States of America (hereinafter referred to as USA) is that it has its own peculiar features of the legal credit regulation. The US banking regulation has a special sub-sector, Consumer Protection law, including four primary laws: the Uniform Consumer Credit Code (UCCC ), The Truth in Lending Act (TILA), the Fair Credit Reporting Act (FCRA), and the Law on Equal Credit Opportunities (Equal Credit Opportunity Act (ECOA) [12; 13; 14]. The laws establish "fair" rules for granting a credit and the maximum amount of credit payments as well as the sale of goods rules of installment and deferred payment, and special 
contract clauses, etc. A particular focus is on the methods of judicial protection of the creditor, and the cases where the court is empowered to discharge foreclosure and distress. The laws also secure the consumer rights of the advanced credit repayment without any extra charges or penalties; whereas, if all contractual charges have already been paid, they are subject to corresponding reduction. The US laws guarantee the right of the consumer to receive complete and accurate information on the credit terms. Specifically, the text of the contract must be clear and unambiguous.

Thus, the creditor is obliged to inform the consumer about the annual interest rate, the total amount of payments on the loan, the amount of taxes and other mandatory payments that should be paid in connection with the loan, to disclose to the consumer the terms of the insurance contract, that is entered in order to ensure fulfillment of the credit obligation, as well as to indicate the amount of any other additional costs and penalties related to the conclusion of a consumer lending agreement.

The Law "On Provision of True Information at the Time of Loans Providing" regulates in detail the guarantees of consumer's rights in the course of lending. The most important of these is the obligation of the creditor to provide in writing the information about the "the true coast of credit"), that is determined by the contract, expressed in percentages per annum. The consumer should be informed how such interest has been calculated. Thus, before the bank gives the consumer a so-called credit line, he is obliged to provide the latter with the following information: the full name of the creditor; the amount financed; the financed fee; the annual percentage rates, except the cases when the loan amount does not exceed seventy five dollars and the payment for the loan is no more than five dollars or the amount of the loan exceeds seventy five dollars and the fee for its delivery is no more than seven and a half dollars; total of payment; the amount and period of payments; in case of sale of real estate - total sale price; detailed explanation of all the above conditions of the contract; an indication that the stipulated payment for a pledge (guarantee, suretyship) will be charged in the event of the provision of the said methods of provision; the amount of fines, penalties that may be imposed on the debtor in the event of late payment; the condition whether the consumer has the right to reduce the amount of the loan fee in case of his early repayment or not.

The practice of applying the provisions of the Law "On Providing Reliable Information in Providing Loans" in the American legal system allows 
to identify the most typical violations committed by banks in the field of consumer lending, that, in turn, can be taken into account in order to prevent their occurrence in domestic law enforcement practice. For example, there are frequent cases when in the text of the loan agreement the mandatory for the consumer information is posted in such a way that it is difficult for a professionally unprepared person to separate it from general information; missing the indication of the amount of the provided loan; it is difficult to understand specific terminology; the indication of the amount of the loan is not distinguished from other information that is subject to mandatory notification; there are no indications of the amount of the loan fee and the real interest rate (or it is indicated in the form of annual interest); does not specify a schedule for making payments for repayment of a loan obligation.

It should also be noted that one of the peculiarities of American legislation governing consumer credit relations is the detailed regulation of so-called "consumer credit reports". This special agencies providing creditors certain information about the creditworthiness of the consumer, his personality, reputation, life style, his possibility to non-return the loan and other information collected and used for making decisions about capacity of consumer to meet the demands made within the concluded loan (and, together with it, the insurance) obligation. In addition, US Law "On reliable credit reports" ban discrimination in every sphere of lending activities including advertising, filing and consideration of loan applications, assessment of creditworthiness, accounting and repayment of the loan. The law also prohibits discrimination based on sex, marital status, age, race, color, religion, national origin, or state aid. Some provisions of this law are quite interesting, for example, creditors are not entitled to demand information about the spouse of consumer except when the latter resides in the municipal building and the other spouse is responsible for the debt or the consumer relies on the income of the other spouse during the repayment. Under the provisions of US law, creditors can not require from the consumer the information about his marital status, ability and attitude to having children, shall not to be interested in information about the source of income of the consumer, if the income is formed by support payments or similar sources of financial assistance. An exception are the cases when the creditor properly clarifies to the consumer that he is not obliged to report such data, if he does not want the creditor to take into account such information during the establishment of creditworthiness. 
The US Law "On Equal Lending Opportunities" sets requirements that also should be observed during implementing consumer lending. It is allowed to use the system of selective provision of a loan, if it is statistically substantiated, does not contradict the legislative requirements and does not allow discrimination on the grounds of age, marital status, sex of the applicant; during assessing the creditworthiness a creditor may not take into account the information contained in telephone directories; if a person submits an application for the provision of an unsecured loan and for confirmation of his creditworthiness indicates that he has certain property, the creditor is entitled to demand the signature of the spouse of the applicant or other person on a document certifying the possession of such property in case of non-repayment of the loan; creditors are obliged to inform consumers about their decision to grant a loan within thirty days; the message is allowed verbally, however, at the request of the applicant, must be made in writing and so on.

The US Law "On Equal Lending Opportunities" sets requirements that also should be observed during implementing consumer lending. It is allowed to use the system of selective provision of a loan, if it is statistically substantiated, does not contradict the legislative requirements and does not allow discrimination on the grounds of age, marital status, sex of the applicant; during assessing the creditworthiness a creditor may not take into account the information contained in telephone directories; if a person submits an application for the provision of an unsecured loan and for confirmation of his creditworthiness indicates that he has certain property, the creditor is entitled to demand the signature of the spouse of the applicant or other person on a document certifying the possession of such property in case of non-repayment of the loan; creditors are obliged to inform consumers about their decision to grant a loan within thirty days; the message is allowed verbally, however, at the request of the applicant, must be made in writing and so on.

\section{Conclusions}

Thus, we can conclude that the legislation of Ukraine in the field of providing banking services to the population lags behind the leading countries of the world for several decades. It is quite clear that the desire of domestic legislators to bring legal regulation of the studied relations closer to the European level, especially today, when the implementation of the national 
strategy of European integration takes place. It is absolutely necessary to take measures to ensure the rights of consumers in the use of consumer lending, the formation of mechanisms for the protection of these rights in case of violation. At the legislative level, it is necessary to consolidate the creditor's duty to provide the consumer with complete information, as well as to determine the liability of creditors for providing incorrect or incomplete information on lending. It's important to regulate the provision of a wide range of banking services in the field of retail consumer lending and mortgages; to ensure the protection of the rights of citizens during using such loans; to simplify procedures for foreclosure by lending institutions; to expand the list of means of securing an obligation; unify the procedures for satisfying collateral-secured claims of creditors, including the cases not related to the liquidation and bankruptcy of the debtor.

The analysis above proves that the legislation of Ukraine regulating bank services is decades behind the leading countries of the world. All of this explains an appropriate desire of domestic legislators to bring legal regulation of the relations at issue in line with the European standards that is essential for implementing the national EU-integration policy.

On the basis of the foregoing, it should be noted that in the pre-revolutionary period of rule-making for the regulation of relations that arose in connection with the time-limit, paid transfer of money or things determined by the generic features to the ownership used traditional, known from the time of Roman private law, civil-law construction of the contract loans. The first mention of the credit transaction in the scientific legal literature is related to the provision of a sign of consensus to the real loan relationship. It was assumed that individuals could agree on a promise to provide a loan qualifying as a preliminary loan agreement. In connection with the further development of the banking system, this promise was transformed into a loan agreement that eventually turned into an independent civil law institute. So, in Soviet times, already in the process of financial reform of 1930-1931 years the credit was introduced in the civilian turnover as an independent type of contract. Further development of this legal institute established in Art. 382 of the Civil Code of the Ukrainian SSR in 1964, that established lending to state organizations, collective farms and other cooperative and non-governmental organizations in accordance with approved plans by issuing targeted fixed-term loans. With the adoption of the Fundamentals of Civil Legislation of the USSR and the republics the 
loan was granted the status of an independent civil-law agreement (Article 114), which, having acquired a consensus character, did not lose its clan belonging to the loan agreement. This led to the possibility to regulate such relationships by applying general provisions on a loan agreement to them. Subsequently, such an approach was used by the legislator in preparing the relevant sections of the Civil Code of Ukraine in 2004, that explains the absence in the contents of the said legal act of separate provisions dealing with relations of, for example, consumer lending. As for the latter, it should be noted that they have become widespread in the society during the Soviet period, however, at that time, consumer lending was mostly identified with a commercial loan (relations that arose in connection with the provision of an advance, prepayment, deferral or installment payment) It is worth pointing out that, in general, during the period of socialism, credit relations were used in the sphere of "planned" economies and served as a way of distributing public credit resources not only to legal entities, but also to citizens.

Currently, the domestic legislation regulates the relations of consumer lending are more perfect in the field of consumer rights protection in comparison with other countries of the post-Soviet area. As for the EU countries, the legal regulation and practical application of the credit institution used by the participants in civilian circulation to meet their economic needs is deprived of those gaps existing in the domestic legal system. In particular, it is a question of the uncertainty in the Ukrainian legislation of issues related to the use of misleading advertising by banks concerning lending conditions, incomplete disclosure of information, difficulties encountered in assessing the borrower's creditworthiness, the status of a credit intermediary, establishing unfair terms of consumer credit agreements, imposing by banks and other institutions of additional and related services, lack of equal requirements to creditors, etc.

All things considered are evident that the change in the political and economic situation in our country directly influenced the legislator's approach to the legal regulation of credit relations. The transition of social relations to the market economy has led to increased acquisition by the subjects of the civilian turnover of goods and services on credit. However, the current legal credit regulation does not always meet the requirements of practice. To date, Ukrainian legislation has legal acts that regulate lending relations, while in the EU countries, credit agreements have been regulated at the level of separate legislative acts since the previous century. Therefore, the 
foreign practice of the separate credit institution has already deprived of those gaps that Ukrainian legal system still need to fill up. In order to eliminate the problems of legal consumer credit regulation it is necessary to bring the legislation of Ukraine into conformity with the best international practice.

\section{References:}

1. Shirshenevich G. (2003) Kurs torgovogo prava: tovar, torgovyje sdelki [Course of commercial law: goods, trade transactions] T 2, Moscow: Statut. (in Russian)

2. Denburg G.( 1904) Pandecty : Objazatelstvennoje parvo [Pandekty: Liability Law] T. 3. (eds. P. Sokolovskogo; trans.: A. G. Gojbarg, B. I. Elkin), Moscow : Univ. tip. (in Russian)

3. Postanova pro vvedennja v diju Osnov zcivilnogo zakanadelstva Sojuza RSR i respublik (1991) [Decree on the enactment of the Fundamentals of Civil Legislation of the Union of Soviet Socialist Republics and the Republics]. Vidomosti Zjezdu narodnyh deputativ SRSR s Verhovnoi Rady SRSR [Information from the Congress of People's Deputies of the USSR and the Supreme Soviet of the USSR], no. 26, st. 734 .

4. Osnovy zcivilnogo zakanadelstva Sojuza RSR i respublik (1991) [Fundamentals of civil legislation of the Union of Soviet Socialist Republics and the republics]. Vidomosti Zjezdu narodnyh deputativ SRSR s Verhovnoi Rady SRSR [Information from the Congress of People's Deputies of the USSR and the Supreme Soviet of the USSR], no. 26, st. 733.

5. Zcivilny kodeks Ukrainy: ofitsiyne vydannya (2004) [Civil Code of Ukraine: official publication]. Kyiv: Atika. (in Ukranian)

6. Postanova pro prodazh gromadjanam tovariv tryvalogo korystuvanja $\mathrm{v}$ kredit (1954) [Resolution on sale to citizens of durable goods on credit]. Retrieved from: http://zakon4.rada.gov.ua/laws/show/299-85-\%D0\%BF. (viewed 21 February 2018).

7. Postanova Rady Ministriv URSR Pro zhytlovo-budivelnu i dachno-budivelnu kooperazcii (1958) [The resolution of the Council of Ministers of the Ukrainian SSR On housing and construction and cottage-building cooperatives]. Zibrannya postanov Uryadu URSR [Collection of resolutions of the Government of the USSR]. no. 7, st. 132 .

8. Zakon Ukrainy Pro finansovi poslugi ta derzhavne reguluvannja rynkiv finansovyh poslug (2002) [Law of Ukraine On Financial Services and State Regulation of Financial Services Markets]. Vidomosti Verhovnoi Rady Ukrainy [Information from the Verkhovna Rada of Ukraine]. no. 1, st. 1.

9. Zakon Ukrainy Pro zahyst prav spozhyvachiv (1991) [Law of Ukraine on consumer protection]. Vidomosti Verhovnoi Rady URSR [Information from the Verkhovna Rada URSR ]. no. 30, st. 379.

10. Zakon Ukrainy Pro spozhyvche kredytuvannja (2017) [Law of Ukraine on consumer lending]. Vidomosti Verhovnoi Rady Ukrainy [Information from the Verkhovna Rada of Ukraine]. no. 1. st. 2. 
11. Direktiva Evropejskogo Parlamenta i Soveta EC o dogovorah potrebytelskogo kredytovania (2008) [Directive of the European Parliament and the Council of the European Union on consumer credit agreements]. Retrieved from: http://zakon3.rada.gov.ua/laws/show/994_b19. (viewed 21 February 2018).

12. Consumer Credit Protection Act, United States Code (USC). Retrieved from: http://www.access.gpo.gov/uscode/title15/chapter41_html (viewed on 20 February 2018).

13. Report on the Implementation of the Consumer Credit Directive 2008/48/ EC / Committee on the Internal Market and Consumer Protectione (2012) Retrieved from: http://www.europarl.europa.eu. (viewed on 20 February 2018). - Title from the screen.

14. Study on the Calculation of the Annual Percentage Rate of Charge for Consumer Credit Agreements: Final Report / European Commission Directorate General (2009) Retrieved from: http://www.ec.europa.eu. (viewed on 20 February 2018). 
LAW \& MANAGEMENT: A NEW APPROACH FOR SCIENTIFIC RESEARCHES AND THE MANAGERIAL PRACTICE

\title{
LAW \& MANAGEMENT: НОВИЙ НАПРЯМ НАУКОВИХ ДОСЛІДЖЕНЬ ТА УПРАВЛІНСЬКОЇ ПРАКТИКИ
}

\section{Shevchenko Liudmyla ${ }^{1}$}

DOI: http://dx.doi.org/10.30525/978-9934-571-29-9_12

\begin{abstract}
The purpose of this article is to disclose the sense of the Law \& Management conception and to reveal opportunities of its practical implementation in Ukraine. The methodological basis of the study is the systematic and logical analysis of the scientific approaches of foreign scientists to development of the Law \& Management conception and a model of the interrelation between law and management. The author proposes an own explanation of the essence of the question, having separated notions of "legal management" and "law practice management".

Legal management is referred to as a system of managerial relations and ac-tions, which are based on awareness of managers and their adherence to law norms and regulated by the current legislation and job descriptions (at an organization) with strict defining and optimal division of juridical rights and obligations of managers. That is to say, it is the legally standardized managerial activity in any field of economic operations. Legal regulation of managerial relations enables to organize actions of managers strictly. Moreover, application of instruments of legal streamlining the economic activity is a component of management of organizations that qualitatively changes its content. Many firms tend to develop special legal strategies. The author means an algorithm calculated from the standpoint of the current legislation. This algorithm provides making legally significant decisions at each stage of business development, determining prospects of licit generation of incomes, emergence of entrepreneurial risks, their legal consequences for a firm, and legal mechanisms of business protection. Legal procedures and instruments such as due diligence, compliance, forensic, government rela-
\end{abstract}

${ }^{1}$ Doctor of Economic Sciences, Full Professor,

Head of Economic Theory Department,

Yaroslav Mudryi National Law University, Ukraine 
tions, and investment relations are used for managing a firm. Nevertheless, neither legal norm stipulates economic relation on its own. This requires management and managers. Managers with knowledge of law, lawyers with knowledge of management, legal advisers, and business advisers are the main subjects of legal management. University education programs in legal management in many countries of the world propose such variety of jobs. Realizing peculiarities of legal management, foreign scientists use a notion of "legally astute manager".

Law practice management contemplates performing functions of management directly in the field of law, namely at law firms. A legal manager is its subject. Functions of the latter encompass planning and development of a strategy for law firm development, organizing and coordination of practical legal activity, estimation of quality of work and stimulation of lawyers' work, application of professional skills for work with legislation, internal normative documents, and business documentation of a firm, settlement of internal conflicts at a law firm, etc. Actions of legal managers have own specificity. They are stipulated by peculiarities of a law firm as an economic entity, specificity of the industry of legal services business, legal practices, and rendering legal services, as well as national traditions of managing law firms in some countries. In Ukraine, law firms gradually master directions of management being new for them, particularly strategic, operational, situational, and anti-crisis management. Being innovative and combining with principles of effective management of human resources, law practice management more and more actively orients towards the legal services market. Development of professional partnership occurs in the global market of legal services. The law firms become members of international managerial associations.

The modern business requires specialists with fundamentally new competencies. It puts new challenges before the legal education of managers and managerial education of lawyers.

The theoretical conception of Law \& Management may be the basis for im-provement of the practical managerial activity through application of instruments for legal regulation of the economic activity and development of special legal strategies. Simultaneously, achievements of management enable to thoroughly understand specificity of managing and managed systems, scopes of legal regulation, actions of certain administrative acts, opportunities and consequences of the influence of law on the economy and management. 


\section{Shevchenko Liudmyla}

\section{1. Вступ}

Традиційним напрямом міждисциплінарних наукових досліджень для економістів і юристів $\epsilon$ Law \& Economics, або «економічний аналіз права» (інколи «правова економіка»). Його прибічники, визнаючи право одним із найвпливовіших інститутів економічної діяльності, намагаються показати можливості економічної теорії в аналізі правової реальності, виявленні суперечностей конкретних норм права та можливостей їх корекції, обгрунтуванні напрямів реформування правовідносин. Однак не менш важливою для теорії та практики $\epsilon$ спрямованість наукового пошуку на формування концепції Law \& Management, або «управлінського аналізу права», «юридичного менеджменту». При цьому йдеться саме про менеджмент, тобто управління соціально-економічними процесами на рівні організації, основною фігурою якого є менеджер. Якщо ж дослідження і практика зосереджуються на поведінці економічних суб'єктів безпосередньо у сфері права, говорять про «менеджмент юридичної практики (фірми)».

Мета статті - розкрити теоретичні основи концепції Law \& Management, особливості правової регламентації управлінських дій менеджерів, зміст понять «юридичний менеджмент» і «менеджмент юридичної практики (фірми)» та можливості їх практичної реалізації в Україні.

\section{2. Право і менеджмент}

Як методологічний підхід, Law \& Management започаткували A. Masson i H. Bouthinon-Dumas. Своє завдання вони вбачали в тому, аби обгрунтувати роль права як ключового фактору успіху компанії, пояснити високу ефективність окремих бізнес-організацій, які перебувають в одному правовому полі (середовищі) з іншими, використанням переваг права та закону для досягнення своїх господарських (економічних) цілей, розробкою та реалізацією правових стратегій [1].

Зараз Law \& Management розвивають переважно американські, сканди-навські та французькі вчені. Так, С. E. Bagley та D. W. Savage аналізують інтеграцію ділового законодавства з етикою та ефективним управлінням, бачать майбутнє за менеджерами 3 юридичними знаннями та володінням методиками управління ризиками в глобаль- 
ному правовому середовищі [2]. В інших своїх працях С. Е. Bagley розробляє проблеми інтегрування права та стратегії, використання правових інструментів для створення конкурентоспроможного бізнесу [3], активного управління юридичними аспектами бізнесу [4]. R. C. Bird з'ясовує взаємозв'язок права, стратегії та конкурентних переваг фірми [5]. R. C. Bird, P. Borochin та J. Knopf досліджують роль головного юрисконсульта в питаннях корпоративного управління [6].

Слід відзначити також численні публікації G. Siedel. Наприклад, G. Siedel i H. Наaрiо у книзі «Проактивне право для менеджерів: приховане джерело конкурентної переваги» стверджують, що ефективні менеджери використовують знання права для мінімізації витрат і ризиків, утримання в організації ключових талантів, співробітництва в галузі інновацій, захисту інтелектуальної власності, створення цінностей для клієнтів. Автори розрізняють реактивний підхід менеджерів, коли вони вже стикнулися 3 правовими проблемами (законом) і змушені на них реагувати, та активний, який дозволяє використовувати право (закон) для упередження проблем, що сприяє успішному бізнесу та досягненню конкурентних переваг. Проактивне право передбачає розроблення юридичного плану дій менеджера [7]. Ідеям проактивного права присвячено ще спільну статтю G. Siedel i H. Haаpio [8]. В інших своїх публікаціях G. Siedel аналізує зв'язок стратегічного менеджменту, права та етики [9], роль права у створенні конкурентних переваг фірми [10].

В Україні до цього часу аналогічні дослідження концентруються переважно навколо питань взаємозв'язку права та управління у широкому розумінні слова. Для юристів традиційним є вивчення насамперед соціального управління людьми та їх колективами у формі державного управління, суб'єктом якого є держава, та громадського управління, суб'єктом якого є недержавні організації. Право при цьому визначає правові основи управління, компетенцію його органів, зміст, форми й методи їхньої діяльності, і водночас регулює управлінську діяльність. Прихильники нормативістської концепції права загалом визнають управління лише інструментом застосування правових норм, а «управлінське право» трактують як «адміністративне право». Однак $є$ й ті, хто, навпаки, відстоює незалежність управління від права. 


\section{Shevchenko Liudmyla}

Розгляд взаємозалежності права і менеджменту здійснюється в іншій площині і має більш прикладний характер. Суспільствознавці відзначають спільні риси права та менеджменту: спрямованість управлінського та правового впливу на організацію, координацію, упорядкування спільної діяльності людей; на досягнення бажаної поведінки та загального стану керованої системи (підсистеми). При цьому юристи-практики доводять, що кожне управлінське рішення менеджерів повинно базуватися на знанні права, бути юридично оформленим у вигляді наказу, розпорядження, доручення адміністрації фірми (підприємства) та узгоджене з чинним законодавством. Натомість фахівці 3 менеджменту висувають нові вимоги до підготовки юристів у вищій школі: майбутні юристи повинні не тільки мати глибокі управлінські знання, а й сформувати вміння та навички юридичного управління організаціями на різних рівнях та посадах. А також ставлять питання про запровадження принципів менеджменту в юридичному бізнесі [11]. У такому контексті працюють учені-економісти Національного юридичного університету імені Ярослава Мудрого [12; 13; 14; 15$]$.

Аналіз співвідношення права та менеджменту виявляє їх прямі та зворотні зв'язки. 3 одного боку, розвиток правової науки залежить від напрацювань менеджменту: останні дають змогу глибше зрозуміти специфіку керуючих та керованих систем, рух інформаційних потоків на рівні суб’єкта господарювання, межі правового регулювання та дії конкретних адміністративних актів, які приймаються в процесі управління, можливості й наслідки впливу права на економіку та управління. Слід зважати й на те, що теорія і особливо практика менеджменту динамічно розвиваються. 3'являються не тільки нові концепції управління, а й види діяльності, зміст яких потрібно опановувати юристам.

3 другого боку, право багато в чому визначає цілі, завдання, принципи менеджменту, встановлює юридичну відповідальність суб'єктів управління за правопорушення в економічній та управлінській сферах. Проблема полягає у тому, що управлінські відносини на рівні організації є доволі складними, перебувають під впливом економічних, політичних, ідеологічних, морально-етичних та інших суспільних відносин. Їх потрібно розглядати як цілісну управлінські систему, з чітким виокремленням суб'єкта, об'єкту управління та керуючих впливів 3 метою досягнення бажаного стану всієї системи. 
За своїм змістом управлінські відносини є організаційними, такими, що:

- формують, узгоджують і впорядковують спільні дії людей та їх колективів із метою реалізації цілей і завдань, що стоять перед ними;

- мають суб'єктно-об'єктний характер. Одна сторона управлінських відносин є керуючою підсистемою управління (його суб'єктом): наділена певними повноваженнями, впливає на інших, використовуючи свою владу, але й несе відповідальність за організацію. Друга сторона утворює керовану підсистему управління (його об'єкт), відчуває на собі керуючий (регулюючий) вплив і підкоряється йому. Саме в керуючому впливі суб'єкта на об'єкт виражаються суть управлінської діяльності, свідомо-вольові зв'язки людей;

- виявляють себе через відносини субординації та координації. Якщо субординація означає підпорядкування підлеглих керівнику і виконання його управлінських рішень, то відносини координації - взаємне погодження цілей та дій членів організації, що знаходяться на одному ієрархічному рівні управління;

- можуть бути формальними (офіційними) і неформальними.

Правова регламентація управлінських відносин дає змогу більш чітко організувати дії менеджерів. Фахівці у сфері юридичної практики взагалі вважають, що розвиток управлінських відносин на різних рівнях господарювання не можливий без правових форм, які б їх закріплювали, підтримували та убезпечували. Більш того, такі функції менеджменту, як організація, мотивація (особливо примушування як форма негативної мотивації) та контроль, неодмінно мають бути підкріпленими посадовими інструкціями з визначенням юридичних прав та обов'язків сторін. Інакше будь-які відхилення від вимог менеджменту матимуть заперечні наслідки для організації.

\section{3. Юридичний менеджмент}

У закордонному англомовному середовищі вживаються терміни "legal management" та "law practice management". Вони відбивають різні аспекти та рівні практичної реалізації ідей Law \& Management.

"Legal management" (LM), або юридичний менеджмент, означає систему управлінських відносин і дій, які базуються на знанні та дотриманні управителями норм права, регламентуються чинним законодавством, а в середині організації - посадовими інструкціями 


\section{Shevchenko Liudmyla}

3 чітким визначенням та оптимальним розподілом юридичних прав та обов'язків менеджерів. Тобто це юридично внормована управлінська діяльність у будь-якій сфері господарювання.

Використання інструментів правового впорядкування господарської діяльності вже стало складовою менеджменту організацій і якісно змінює його зміст. Так, багато бізнес-організацій удаються до розроблення спеціальних правових стратегій. Їх необхідність пояснюють тим, що на поведінському рівні дії суб'єктів господарювання можуть мати різні юридичні наслідки в різних їх комбінаціях. Правова стратегія, як і будь-яка інша стратегія, спирається на перспективне прогнозування і планування, виявлення довгострокових трендів розвитку організації, для якої вона розробляється, знання цілей і завдань, можливостей і обмежень діяльності. Це не діяльність як така, а особливий тип комунікації, в якому суб'єкт права вступає у взаємодію в ситуації невизначеності. Об'єктом спостереження є не факти, а очікування, відповідно дії партнерів оцінюються не так за наслідками, як за можливістю, яка лише вгадується [16, с. 77-78]. У практичному плані правова стратегія бізнесу - це прорахований із точки зору чинного законодавства алгоритм прийняття юридично значущих рішень на кожному з етапів розвитку бізнесу, з визначенням перспектив законного отримання доходів, виникнення підприємницьких ризиків та їх можливих правових наслідків для фірми, а також правових механізмів захисту бізнесу.

Однак юристи слушно ставлять питання про юридичну (правову) стратегію у широкому розумінні, яка включає питання перспективного планування і прогнозування, концептуальні і довгострокові проблеми розвитку самого законодавства. Як підкреслює А. Н. Міронов, цілі в праві мають велике значення. Заради них приймаються нормативні правові акти. Для того, щоб регулювання суспільних відносин було результативним, потрібно враховувати інтереси учасників даних суспільних відносин. Юридична стратегія нормативного правового акту дозволяе створити ефективні нормативні правові акти, не допустити в майбутньому помилок у правотворчості та правозастосуванні, вести мову про ефективність нормативних правових актів на більш ранній стадії, ніж на стадії їх реалізації [17].

Для управління фірмою застосовують різні юридичні процедури та ін-струменти - залежно від загальної стратегії фірми, іiі зовніш- 
нього середовища та динаміки розвитку бізнесу. Наприклад, головною метою due diligence, який ще називають юридичним аудитом, $\epsilon$ встановлення незалежними експертами достовірності фінансової, податкової та статистичної звітності, правильності оформлення всіх документів компанії, їх відповідності законодавству та внутрішнім вимогам, оцінки підприємницьких ризиків. Практика compliance тісно пов'язана з ризик-менеджментом і передбачає напрацювання рекомендацій з управління небезпеками, які виникають через недотримання вимог законодавства, правил і стандартів наглядових органів, галузевих асоціацій та самоврядних організацій, кодексів корпоративної поведінки (етики), політики конфіденційності даних, правил використання інсайдерської інформації тощо. Антикорупційний compliance спрямовується на розроблення кодексу етики організації, розслідування порушень антикорупційного законодавства та корпоративних політик компанії, виявлення джерел корупційних ризиків у діяльності фірми та їі клієнтів та напрацювання рекомендацій щодо їх усунення. Набуває актуальності й практика forensic - діяльність із виявлення ключових ризиків, а також аналізу та врегулювання конфліктних ситуацій, які виникають між діловими партнерами. Суперечності можуть бути спричиненими як різними поглядами на ведення бізнесу та діями, пов'язаними зі значними економічними ризиками, так і підозрами у скоєнні злочинів окремими співробітниками чи навіть організаціями (корупції, шахрайстві, зловживаннях службовим становищем, розкраданні активів компанії тощо). Причинами цього часто є відсутність антикорупційної нормативно-правової бази, систем внутрішнього контролю зловживань на підприємстві, практики проведення регулярного фінансового аудиту; а також низький рівень зарплат та інших заохочувальних виплат на підприємстві.

Останнім часом актуальними стають практики, пов'язані з супроводом інвестиційних проектів: government relations - встановлення взаємодії з органами державної влади з метою успішної діяльності фірми та реалізації підприємницьких проектів, особливо інвестиційних; investment relations - правової підтримки взаємодії з інвесторами; упередження недружнього збагачення учасників інвестиційного проекту.

Утім жодна правова норма, регламентуючи певні господарські відносини, сама по собі їх не реалізує. Для цього потрібен менеджмент і менеджери. 


\section{Shevchenko Liudmyla}

Основними суб'єктами LM є менеджери зі знаннями права, юристи зі знаннями менеджменту, юрисконсульти, бізнес-консультанти. Такий розбіг професійних посад пропонують університетські освітні програми з юридичного менеджменту у багатьох країнах світу. У США, скажімо, випускники Університету Каліфорнії у Берклі стають висококваліфікованими професіоналами як у сфері права (адміністративного, цивільного, кримінального, трудового, конституційного, комерційного фінансового тощо), так і в сфері бізнесу (бухгалтерського обліку, економіки, фінансів, маркетингу, управління персоналом, стратегічного менеджменту, управління якістю тощо).

Залежно від юридичної школи, випускникам можуть присвоюватися ступені Juris Doctor (JD) або бакалавра права (Ll.B.), а також: бакалавр наук у галузі юридичного менеджменту; бакалавр мистецтв в юридичному управлінні (АВ Legal Management); бакалавр мистецтв у галузі правових досліджень (AB Legal Studies); бакалавр мистецтв у паралегальних дослідженнях (АВ Paralegal Studies); бакалавр наук у галузі ділового адміністрування, магістр юридичного менеджменту та ін. [18]. Деякі випускники визнають себе паралегалами (помічниками юристів або керівників із правових питань, середнім юридичним персоналом), адвокатами, політичними аналітиками, політиками, державними адмі-ністраторами, підприємцями, керівниками бізнесу.

Усвідомлюючи особливості юридичного менеджменту, С. E. Bagley та D. W. Savage ввели поняття "legally astute manager" - «юридично обізнаний (обачний) менеджер», який розуміє правові аспекти бізнесу, може використати закон та правову систему, щоб збільшити загальну вартість фірми, захистити власність акціонерів.

Юридично обізнані (обачні) менеджери:

1) мають не тільки управлінські, а й спеціальні правові знання, уміють застосовувати правові інструменти, творчий потенціал юридичної мови. Такі менеджери краще підготовлені до спілкування з юристами та адвокатами;

2) спираються на юридичні міркування на кожному етапі розроблення та впровадження стратегії. Вони завчасно приймають поради й вимагають юридичної консультації, орієнтованої на бізнес, не чекаючи, поки виникла якась проблема або загрози розвитку фірми; 
3) розуміють, що юридичний аналіз часто неоднозначний, і для управління правовими аспектами бізнесу потрібне обгрунтоване судження. Навіть найбільш кваліфіковані та досвідчені радники, у тому числі юристи, іноді помиляються. Висновок юриста може бути затьмареним особистими інтересами, такими як збільшення оплачуваних годин, кількості повноважень в рамках фірми тощо;

4) можуть вести переговори щодо укладення контрактів, використовувати методи зменшення трансакційних витрат, підвищення вартості фірми та управління ризиками;

5) беруть на себе відповідальність за управління правовими аспектами бізнесу, юридичними суперечками, які вимагають свого розв'язання [2, с. 10-12].

На практиці співвідношення «право - менеджмент» не є простим. Право спрямовує менеджера на діяльність у рамках законності, але менеджер має можливість вибору й інших способів і методів розв'язання проблем в організації. Наприклад, економічні методи менеджменту передбачають вплив на виконавців за допомогою вимірювання затрат і результатів праці. Основним важелем є система оплати праці, яка має бути максимально пов'язана з результатами діяльності виконавця. Соціально-психологічні методи реалізуються у формі морального заохочення, переконання, повчання, творчого розв'язання конфліктів, створення і підтримки атмосфери дружби та довіри в колективі. Більш того, органі-заційно-технічні, соціально-психологічні та психолого-педагогічні управлінські відносини правом взагалі не регулюються.

\section{4. Менеджмент юридичної практики}

Термін "law practice management” (LPM), або менеджмент юридичної практики, уживають, коли говорять про здійснення функцій менеджменту в юридичних фірмах (далі - ЮФ). Суб'єктом LPM є «юридичний менеджер».

Чи має він якусь специфіку порівняно з менеджером? У західних країнах менеджером є управитель, який: 1) обіймає постійну посаду в організації; 2) має чітко встановлені повноваження та межі відповідальності за прийняття рішень по конкретних напрямах діяльності; 3) організує ті чи інші роботи за допомогою підпорядкованих йому працівників; 4) має спеціальну менеджерську 


\section{Shevchenko Liudmyla}

підготовку, управлінські знання, уміння та навички; 5) має здібності до роботи з людьми. Кінцевою метою діяльності менеджера $є$ забезпечення сталого розвитку організації, зростання іiі конкурентоспроможності.

Усі ці риси притаманні й юридичному менеджеру. До його функцій належать планування та розроблення стратегії розвитку ЮФ; організація та координація практичної юридичної діяльності; оцінка якості роботи та стимулювання праці юристів; використання професійних знань для роботи з законодавством, внутрішніми нормативними документами та діловою документацією фірми; врегулювання внутрішньофірмових конфліктів у самій ЮФ та інше.

Утім, дії юридичних менеджерів обумовлені особливостями ЮФ як суб'єктів господарювання. ЮФ - це «відокремлений індивідуальний суб'єкт господарювання ринку юридичних послуг, який здійснює підприємницьку діяльність, спрямовану на задоволення суспільних та індивідуальних потреб у правовій допомозі з метою досягнення певного правового результату та одержання прибутку» $[14$, с. 78$]$. Юридичний менеджер повинен розумітися на індустріях юридичного бізнесу як певних сферах суспільної життєдіяльності, а також на юридичних практиках - галузях права і певних видах юридичних послуг.

Крім того, юридичний менеджер має зважати на специфіку надання юридичних послуг. Дії фахівців із права за своєю природою є професійними, спрямованими на задоволення потреб чи забезпечення вигод фізичних та юридичних осіб у процесі надання їм юридичної допомоги. Водночас робота юриста є інтелектуальною, потребує спеціальної підготовки й знань, а їі змістом є правові знання, які виступають продуктом осмислення і використання правової інформації. Самі юридичні послуги при цьому стають спеціальним каналом поширення правових знань та інформації [12, с. 89-92].

Юридичний менеджер повинен розуміти також, що діяльність ЮФ має орієнтуватися не на одну угоду купівлі-продажу, а на тривалу взаємодію, близькі й часті контакти 3 клієнтами, створення для них цінності. Між ЮФ і клієнтами в ідеалі мають формуватися не тільки економічні, а й соціальні відносини, засновані на особистій прихильності, лояльності і партнерстві. Саме партнерські відносини забезпечують фірмам бажану високу дохідність і стійкі конкурентні переваги. Кон- 
куренти можуть мати схожі ресурси, але запізнитися зі встановленням партнерських відносин із клієнтами (споживачами). У зв'язку з цим велике значення має репутація ЮФ та історія взаємовідносин юристів із клієнтами. Найбільш надійним інструментом залучення клієнтів в юридичному бізнесі є рекомендації, надання яких тотожне довірі до ЮФ. Для створення потоку рекомендацій потрібна мережа людей, які знають, чим займається ЮФ, та високий рівень довіри до юристів фірми. Така мережа повинна бути стабільною, передбачуваною і такою, яку можна відтворити в іншому місті або навіть країні. Усе це завдання репутаційного менеджменту, вкрай важливого для розвитку юридичного бізнесу.

Нарешті, існують і національні традиції управління ЮФ. У більшості країн світу юридичний менеджер, як правило, суміщає виконання своїх обов'язків із роботою юриста фірми. Однак якщо у США Модельні правила Американської асоціації юристів прямо забороняють власникам ЮФ залучати до складу засновників сторонніх інвесторів, а до управління - професійних менеджерів, то в країнах англо-саксонського права спостерігається тенденція до лібералізації законодавства. У Великій Британії керувати юридичними фірмами вже можуть люди без юридичної освіти. Причому очікується, що тенденція поділу працівників сектору юридичних послуг на професійних юристів і працівників без юридичної освіти, які обслуговуватимуть бізнес чи навіть безпосередньо керуватимуть фірмою, буде тільки посилюватися [19].

LPM в Україні постійно розвивається і набуває нових рис.

По-перше, вітчизняні ЮФ поступово опановують нові для них напрями менеджменту - стратегічний, оперативний, ситуаційний, антикризовий тощо. Стратегічний LPM спрямовується на вибір тих індустрій, юридичних практик і ринків юридичних послуг, на яких ЮФ має явні конкурентні переваги, а також на напрацювання стратегій і програм діяльності на кожному з таких ринків. Оперативний LPM означає практичну діяльність управлінців із реалізації обраної ЮФ стратегії. Ситуаційний LPM вимагає від юридичного менеджера правильного розуміння причин та оцінювання наслідків тих конкретних обставин, які в даний момент найбільше впливають на ЮФ та досягнення нею своїх цілей. Антикризовий LPM ураховує циклічність розвитку ЮФ, а також імовірність виникнення в ЮФ кризових станів 
під впливом змін внутрішніх і зовнішніх факторів господарювання. Як свідчить практика, навіть в успішних ЮФ із певною періодичністю виникають кризи, більшість із яких є управлінськими.

По-друге, LPM дедалі активніше застосовує концепцію маркетингового менеджменту та орієнтується на ринок юридичних послуг. Юридичний маркетинг визначають як дії професійних юристів із використанням маркетингових інструментів, що спрямовані на формування ринку юридичних послуг, побудову оптимальних відносин iз замовниками та задоволення їх потреб, і водночас на одержання прибутку компанії за рахунок високого конкурентного статусу. Так, компанія "LMS" спеціалізується на стратегічному консалтингу 3 питань юридичного маркетингу та юридичного менеджменту. ЮФ “AEQUO” на своєму офіційному сайті пропонує виявлення потреб бізнесу в зміні законодавства, правовий аналіз законодавчих ініціатив, їх можливих наслідків для бізнес-клієнтів та інших зацікавлених сторін, підготовку законопроектів і норматив-них актів шляхом взаємодії з державними органами й членами парламенту. У світі існують навіть випадки створення віртуальних юридичних фірм, коли команда фахівців підбирається спеціально під конкретний проект чи справу та працює дистанційно. Ця практика дозволяє максимально ефективно застосувати професіоналізм юридичного персоналу для виконання своїх прямих обов'язків і задоволення попиту на ринку юридичних послуг.

По-третє, сучасний LPM є інноваційним, а ЮФ активно цікавляться біз-нес-моделлю «внутрішнього підприємництва». ЮФ продукують насамперед юридичні інновації: нові правові знання; нові або вдосконалені технології на-дання юридичних послуг; нові юридичні послуги й практики тощо. Однак надання сучасних юридичних послуг неможливе без застосування новітніх технологій (упровадження корпоративного програмного забезпечення для роботи 3 юридичною інформацією і документообігом, електронного білінгування, виставлення рахунків, керівництва процесом прийняття рішень тощо). Технологічні інновації, у свою чергу, зумовлюють організаційні зміни (вдосконалення форм і структур управління ЮФ, формування проектних команд, створення альтернативних провайдерів юридичних послуг та ін.), а ті потребують змін в економіці ЮФ (нових форм роботи з клієнтами на ринку юридичних послуг, актив- 
ного маркетингу в соціальних мережах тощо) та закріплення у нормативно-законодавчих актах.

По-четверте, практика LPM поєднується з принципами ефективного кадрового менеджменту. ЮФ є організацією, що навчається: іiі відзначають високий рівень кваліфікації та професійної відповідальності персоналу, когнітивізація діяльності й нові підходи до управління. Мотиваторами праці юристів стають можливість навчання на робочому місці, з опануванням специфіки роботи фірми та вихованням важливих якостей членів команди; характерні лише для ЮФ форми й методи оплати праці (дисконтовані й усереднені погодинні ставки, фіксовані та граничні тарифи, гонорари успіху тощо), використання систем білінгу та грейдингу. Для молодих фахівців важливе значення має розроблення індивідуального плану розвитку. У західних компаніях такий план $\epsilon$ інструментом прогнозування особистої перспективи юриста в ЮФ, а також напрямів розвитку та конкурентоспроможності самої ЮФ.

В українських ЮФ стали традиційними постійне підвищення рівня про-фесійної підготовки і кваліфікації своїх юристів, організація професійних тре-нінгів. Але в більшості випадків роблять ставку на найм юристів із досвідом роботи. Існують аналоги й грейдингових систем із використанням показників KPI (Key Performance Indicators) залежно від рівня кваліфікації, якості роботи та активності юриста.

По-п'яте, в юридичному бізнесі впроваджується концепція конкурентного менеджменту. Відомо, що ринок юридичних послуг в Україні стає дедалі більш конкурентним. Його загальна ємкість оцінюється приблизно в 12 млрд грн (\$500-700 млн), при цьому на топ-10 найбільших ЮФ України припадає близько 20-30\% ринку, а на топ-50 найбільших ЮФ - 33\% (приблизно 4 млрд грн доходів) [20]. Причому прогнози розвитку конкуренції в юридичному бізнесу є неоднозначними: одні аналітики називають більш стійкими локальні ЮФ; інші поділяють думку, що згодом закордонні міжнародні компанії поглинатимуть українські ЮФ; є й очікування гігантів бізнесу, які будуть конкурувати в своєму середовищі, а решта ринку буде представлена великою кількістю компаній із регіональними практиками.

Конкурентне управління - це менеджмент організації в умовах конкуренції, що зростає. У такому аспекті повинні сприйматися всі напрями функціонального менеджменту ЮФ - менеджмент марке- 
тингу, менеджмент персоналу, виробничий, інноваційний, фінансовий менеджмент тощо. Орієнтуватися на конкурентну боротьбу має і весь цикл управління - процеси планування, організовування, мотивування і контролю. У більш вузькому значенні йдеться про менеджмент конкурентоспроможності ЮФ, призначення якого полягає у виявленні небезпек конкуренції, аналізі інтенсивності конкуренції та типології конкурентних ситуацій в юридичній галузі й на ринку юридичних послуг, оцінках ринкового становища фірми та їі конкурентів, розробці заходів зі зменшення негативних наслідків конкурентної боротьби та використанні механізму конкуренції для сталого економічного розвитку ЮФ.

Динаміка конкурентного управління ЮФ відповідає етапам життєвого циклу фірми. Так, на стадіях створення і становлення ЮФ створює свої конкурентні переваги. Основними завданнями конкурентного управління є: оцінка початкового конкурентного потенціалу ЮФ; обгрунтування конкурентних цілей ЮФ; розроблення конкурентної стратегії та методів іiі реалізації. На стадії піднесення ЮФ стає конкурентоспроможною, здатною випереджати своїх суперників у досягненні поставлених цілей на юридичному ринку. До завдань менеджерів додається розроблення ефективних заходів з якості юридичних послуг та захисту конкурентних позицій ЮФ. На стадії зрілості ЮФ досягає стану конкурентної стійкості. Вона займає стабільне становище в галузі й на ринку, має очевидні конкурентні переваги, які практично не повторюються і не руйнуються, а зберігаються протягом тривалого часу. При цьому ЮФ сама проводить агресивну конкурентну політику. На стадії спаду ЮФ втрачає динамізм свого розвитку, а ії конкуренти захоплюють більшу частку юридичного ринку. Виникає необхідність конкурентного перетворення ЮФ - реорганізації (закриття неприбуткових практик, а інколи, навпаки, приєднання бізнесу менш успішних конкурентів); пошуку нових підходів до управління, зокрема перехід до надання комплексних послуг, які вбирають у себе не тільки юридичні, а й аудиторські, бухгалтерські, консалтингові та інші послуги.

По-шосте, відбувається розвиток професійного партнерства на глобальному ринку юридичних послуг. ЮФ стають членами багатьох міжнародних управлінських асоціацій. Серед них: Американська асоціація адвокатів (Секція управління юридичною практикою) (ABA LPMS); Асоціація юридичних адміністраторів (ALA); Асоціа- 
ція управління юридичною практикою Австралії (ALPMA); Асоціація юридичного менеджменту Британської Колумбії (ВСМА); Міжнародна асоціація правових технологій (ILTA); Міжнародна асоціація управління паралегалами (IPMA); Асоціація юридичного маркетингу (LMA); Форум партнерів (MFP); Асоціація професіоналів юридичної кар'єри (NALP); Асоціація управління адвокатськими бюро (TLOMA) та інші [21].

\section{Law \& Management: освітній аспект}

Постійні динамічні зміни в сфері юридичної практики висувають нові вимоги до підготовки юристів у вищій школі. Майбутні правники повинні не тільки мати глибокі економічні та управлінські знання, а й усвідомити необхідність запровадження концепції менеджменту в сфері юридичного обслуговування бізнесу, сформувати вміння та навички управління юридичною фірмою на різних рівнях та посадах. Цьому сприяє компетентнісний підхід до організації навчального процесу з вихованням у майбутніх юристів:

a) системного мислення, інноваційності, орієнтованості на клієнта, знань, умінь і навичок ефективної роботи на ринку юридичних послуг. Їх формують нові навчальні дисципліни: юридичний маркетинг, юридичний менеджмент, юридичний консалтинг, юридична інноватика, стратегічне управління юридичним бізнесом тощо. Однак такі дисципліни не викладають ні в юридичних, ні в економічних закладах вищої освіти (3ВО). Або викладають тільки як навчальні дисципліни за вибором студентів чи в межах платних сертифікатних освітніх професійних програм, як це робиться у Національному юридичному університеті імені Ярослава Мудрого («Юридичний бізнес» та «Бізнес менеджмент»). У більшості випадків студенти-юристи змушені здобувати другу вищу освіту у ЗВО економічного та управлінського профілю;

б) здібностей здійснювати професійну експертизу бізнес-проектів своїх клієнтів, застосовувати комплексний підхід до їх обслуговування. За версією журналу "Legal success", юрист також повинен бути фінансистом (зі знаннями антикризового управління), маркетологом, менеджером і HR [22]. Але в навчальних планах українських юридичних 3ВО і факультетів відсутні економічні та управлінські дисципліни; їх не знайти навіть серед дисциплін, які вивчаються за вибором самих студентів; 


\section{Shevchenko Liudmyla}

в) умінь надавати online-послуги як мережевий юрист чи віртуальний адвокат, який потребує технічних знань. У розвинених країнах при прийманні на роботу юристів обов'язково тестують на навички роботи в Інтернет-мережах. Однак у жодному з українських юридичних 3ВО не викладається ні віртуальна (цифрова) економіка, ні віртуальне право. Тільки в Національному юридичному університеті імені Ярослава Мудрого відкрита магістерська програма «Право та технології» спільно зі Школою права Талліннського технічного університету. Натомість фахівців із мережевого права уже зараз готують технічні університети: НТУ «Київський політехнічний інститут», НТУ «Харківський політехнічний інститут», НУ «Львівська політехніка», Дніпровський національний університет імені Олеся Гончара, Одеський національний політехнічний університет;

г) майстерності опановувати нові або суміжні професії. Як приклад: зараз в Україні створюється Служба фінансових розслідувань, яка повинна реалізовувати три місії: попереджувати порушення в економічній сфері, розкривати вже здійснені злочини та наповнювати бюджет. А фінансовий детектив має бути юристом-процесуалістом (знати, як зібрати доказову базу для суду); аудитором (уміти аналізувати бухгалтерські документи) та інформаційним аналітиком (володіти знаннями 3 комп'ютерних технологій та оперувати сучасними інформаційними базами) [23]. Ні юристи, ні економісти таких знань не мають. Тому в Університеті державної фіскальної служби України розроблено нові навчальні плани, які ввібрали в себе найкращий досвід підготовки юристів, фінансистів і IT-аналітиків.

Разом із тим і майбутні менеджери повинні мати професійну юридичну підготовку. Цим почали опікуватися в Національному юридичному університеті імені Ярослава Мудрого при розробленні нових навчальних планів для студентів економічної та управлінських спеціальностей (табл. 1).

Зрозуміло, що можливість для всебічної юридичної освіти економістів і менеджерів мають насамперед потужні юридичні університети. В інших випадках свої послуги пропонують численні комерційні тренінги, бізнес-школи і семінари. Вони дають відповіді на актуальні питання щодо правового забезпечення та супроводу бізнесу, однак системних знань не формують. 
Таблиця 1

Юридична підготовка студентів економічної

та управлінських спеціальностей в Національному юридичному

університеті імені Ярослава Мудрого

\begin{tabular}{|c|c|c|c|c|}
\hline & $\begin{array}{l}\text { Рівень } \\
\text { іідготовки }\end{array}$ & 051 «Економіка» & $\begin{array}{c}072 \text { «Фінанси, } \\
\text { банківська } \\
\text { справа та }\end{array}$ & $\begin{array}{c}073 \\
\text { «Менеджмент» }\end{array}$ \\
\hline & $\begin{array}{l}\text { Обов’язкові } \\
\text { навчальні } \\
\text { дисципліни }\end{array}$ & $\begin{array}{l}\text { - Фінансове та подат- } \\
\text { кове право } \\
\text { - Інвестиційне право } \\
\text { - Економічне право }\end{array}$ & $\begin{array}{l}\text { Фінансове право } \\
\text { Банківське право } \\
\text { Страхове право }\end{array}$ & $\begin{array}{l}\text { - Публічне адміні- } \\
\text { стрування } \\
\text { - Трудове право } \\
\text { - Господарське } \\
\text { право }\end{array}$ \\
\hline & $\begin{array}{l}\text { Навчальні } \\
\text { дисципліни } \\
\text { за вибором } \\
\text { студентів }\end{array}$ & $\begin{array}{l}\text { - Антикорупційний } \\
\text { комплаєнс } \\
\text { - Трудове право } \\
\text { - Корпоративне право } \\
\text { - Правовий захист } \\
\text { економічної конку- } \\
\text { ренції }\end{array}$ & - & $\begin{array}{l}\text { - Медіація } \\
\text { - Адміністративне } \\
\text { право та адміні- } \\
\text { стративна відпові- } \\
\text { дальність } \\
\text { - Адміністрування } \\
\text { місцевого само- } \\
\text { врядування }\end{array}$ \\
\hline & $\begin{array}{l}\text { Обов'язкові } \\
\text { навчальні } \\
\text { дисципліни }\end{array}$ & - & Немає підготовки & - \\
\hline : & $\begin{array}{l}\text { Навчальні } \\
\text { дисципліни } \\
\text { за вибором } \\
\text { студентів }\end{array}$ & $\begin{array}{l}\text { - Право та економіка } \\
\text { - Міжнародне еконо- } \\
\text { мічне право } \\
\text { - Право внутрішнього } \\
\text { ринку СС } \\
\text { - Корпоративне право } \\
\text { ЄС } \\
\text { - Транснаціональне } \\
\text { банкрутство } \\
\text { - Міжнародний } \\
\text { комерційний арбітраж } \\
\text { та медіація }\end{array}$ & & $\begin{array}{l}\text { - Підприємницьке } \\
\text { право }\end{array}$ \\
\hline
\end{tabular}

Джерело: Освітньо-професійні програми Національного юридичного

університету імені Ярослава Мудрого 


\section{6. Висновки та перспективи подальших досліджень}

1. Теоретична концепція Law \& Management може бути основою для вдосконалення практичної управлінської діяльності шляхом використання інструментів правового впорядкування господарської діяльності та розроблення спеціальних правових стратегій. Водночас напрацювання менеджменту дають змогу глибше зрозуміти специфіку керуючих та керованих систем, межі правового регулювання та дії конкретних адміністративних актів, можливості й наслідки впливу права на економіку та управління.

2. Подальші дослідження слід вести в напрямах обгрунтування сутності юридичного менеджменту та менеджменту юридичної практики (фірми).

Юридичний менеджмент є юридично внормованою управлінською діяльністю у будь-якій сфері господарювання. Це система управлінських відносин і дій, які базуються на знанні та дотриманні управителями (юридично обізнаними менеджерами) норм права, регламентуються чинним законодавством, а в середині організації - посадовими інструкціями з чітким визначенням і оптимальним розподілом юридичних прав та обов'язків менеджерів.

Менеджмент юридичної практики передбачає здійснення функцій мене-джменту в юридичних фірмах. Ефективність менеджменту вітчизняних ЮФ багато в чому визначається можливостями упровадження принципів стратегічного, оперативного, ситуаційного, антикризового менеджментів; орієнтацією на динаміку ринку юридичних послуг, використанням прийомів інноваційного та кадрового менеджменту.

3. Сучасна юридична практика висуває нові вимоги до підготовки юристів у вищій школі. В юридичних ЗВО (факультетах) мають викладатися економічні та управлінські навчальні дисципліни, які б сприяли формуванню принципово нових компетенцій: знань, умінь та навичок ефективного менеджменту на різних рівнях та посадах в юридичному бізнесі. У той же час підготовка менеджерів має бути наповнена опануванням знань правових механізмів регулювання підприємницької діяльності.

\section{Список літератури:}

1. Bouthinon-Dumas H., Masson A. Stratégies juridiques des acteurs économiques. Louvain-la-Neuve: Larcier, 2012. 544 p.

2. Bagley C. E., Savage D. W. Managers and the Legal Environment: Strategies for the 21st Century. Mason: South-Western, Cengage Learning, 2010. 1033 p. 
3. Bagley C. E. Winning Legally: the Value of Legal Astuteness. Academy of Management Review. 2008. Vol. 33. No. 2. Pp. 378-390. URL: http://cbagleyhbs. edu.tripod.com/cases/winninglegallyamr.pdf.

4. Bagley C. E. What's Law Got to Do with It: Integrating Law and Strategy. American Business Law Journal. 2010. Vol. 47. Issue 4. Pp. 587-639. URL: http://lawgip.usc.edu/assets/docs/contribute/BagleyIntegratingLawandStrategy.pdf.

5. Bird R. C. Law, Strategy, and Competitive Advantage. Connecticut Law Review. 2011. № 44(1). C. 61-97. doi: http://dx.doi.org/10.2139/ssrn.1327795.

6. Bird R. C., Borochin, P., Knop J. The Role of the Chief Legal Officer in Corporate Governance. Journal of Corporate Finance. 2015. № 34. Pp. 1-22. URL: https://pdfs.semanticscholar.org/ae8e/aab075b92a60cfdbbc725994b753f7 52126a.pdf.

7. Seidel G., Haapio H. Proactive Law for Managers - A Hidden Source of Competitive Advantage. Aldershot: Gower Publishing, Ltd, 2011. 192 p.

8. Siedel G., Haapio H. Using Proactive Law for Competitive Advantage. Ross School of Business Paper. 2010. August 1. No. 1148. doi: http://dx.doi.org/10.2139/ ssrn. 1664561.

9. Seidel G. The Three Pillar Model for Business Decisions: Strategy, Law \& Ethics. Ann Arbor: Van Rye Publishing, LLC, 2016. 252 p.

10. Seidel G. Using the Law for Competitive Advantage (J-B-UMBS Series). Hoboken: Jossey-Bass, 2002. 224 p.

11. Атепалихін A. Post Scriptum: Виклики юридичного менеджменту чи тренди сьогодення? Украӥнський юрист. 2017. № 5. URL: http://jurist.ua/ ?article/1319.

12. Юридична фірма: пошук моделі ефективного менеджменту: наук.-практ. вид. / Л. С. Шевченко, С. М. Макуха, О. С. Марченко та ін. Харків: Право, 2014. $204 \mathrm{c}$.

13. Менеджмент юридичної фірми: конспект лекцій / Л. С. Шевченко, С. М. Макуха, О. С. Марченко, І. А. Вовк, О. В. Овсієнко. Харків: НУ «Юридична акад. України імені Ярослава Мудрого», 2013. 135 с. URL: http://dspace.nlu.edu.ua/bitstream/123456789/1718/1/Pr_39.pdf

14. Марченко О. С. Юридичний консалтинг: сутність та роль у правовій економіці: монографія / О. С. Марченко, О. В. Ярмак. Харків: ФОП Данилко H.C., 2016. 238 c.

15. Марченко О. С. Ринок послуг юридичного консалтингу в умовах інноваційного розвитку економіки: монографія / О. С. Марченко. Харків: Кортес-2001, 2007. 132 с.

16. Пермяков Ю. Е. Правовые стратегии как коммуникативные модели: проблема описания. Правоведение. 2014. № 5(316). С. 73-80.

17. Миронов А. Н. Юридическая стратегия в правотворческой деятельности. URL: https://iteam.ru/publications/legal/section_102/article_4255.

18. Legal management. From Wikipedia, the free encyclopedia. URL: https://en.wikipedia.org/wiki/Legal management.

19. Лахуті Н. Портрет юриста. Закон $i$ бізнес. 2013. № 41(1131). 12.10-18.10. URL: http://zib.com.ua/ua/print/42815-portret_suchasnogo_yurista rozumie_tehnichniy_bik_spravi_spr.html 


\section{Shevchenko Liudmyla}

20. Огляд ринку юридичних послуг України. URL: http:/www.kuluar.com.ua/ 2016/03/31/ohlyad-rynku-yurydychnyh-posluh-ukrajiny

21. Kane S. Legal Management Associations. URL: https://www.thebalance.com/ legal-management-associations-2164614.

22. Кравченко А. Юристы и ІТ-технологии: отчет о проведении в Киеве I Международной конференции юридических инноваций LEGAL TECH KYIV 2016. URL: http://bca.education/yuristy-i-it-tehnologii-otchet-o-provedeniiv-kieve-i-mezhdunarodnoj-konferentsii-yuridicheskih-innovatsij-legal-techkyiv-2016/.

23. Чепурко В. Как стать финансовым детективом. КП Украина. 2017. 28 апреля. № 76. С. 7.

\section{References:}

1. Bouthinon-Dumas, H., \& Masson, A. (2012). Stratégies juridiques des acteurs économiques. Louvain-la-Neuve: Larcier.

2. Bagley, C. E., \& Savage, D. W. (2010). Managers and the Legal Environment: Strategies for the 21st Century. Mason: South-Western, Cengage Learning.

3. Bagley, C. E. (2008). Winning Legally: the Value of Legal Astuteness. Academy of Management Review, 33(2), 378-390. Retrieved from http://cbagleyhbs.edu.tripod.com/cases/winninglegallyamr.pdf.

4. Bagley, C. E. (2010, March 28). What's Law Got to Do with It: Integrating Law and Strategy. American Business Law Journal, 47(4). Retrieved from http://awgip.usc.edu/assets/docs/contribute/BagleyIntegratingLawandStrategy.pdf.

5. Bird, R. C. (2011, February 7). Law, Strategy, and Competitive Advantage. Connecticut Law Review, 44(1), 61-97. doi: http://dx.doi.org/10.2139/ssrn.1327795.

6. Bird, R. C., Borochin, P., \& Knopf J. (2015). The Role of the Chief Legal Officer in Corporate Governance. Journal of Corporate Finance, 34, 1-22. Retrieved from https://pdfs.semanticscholar.org/ae8e/aab075b92a60cfdbbc 725994 b753f752126a.pdf.

7. Seidel, G., \& Haapio, H. (2011). Proactive Law for Managers - A Hidden Source of Competitive Advantage. Aldershot: Gower Publishing, Ltd.

8. Siedel, G. J., \& Haapio, H. (2010, August 1). Using Proactive Law for Competitive Advantage. Ross School of Business Paper, 1148. doi: http://dx.doi.org/10.2139/ssrn.1664561.

9. Seidel, G. (2016). The Three Pillar Model for Business Decisions: Strategy, Law \& Ethics. Ann Arbor: Van Rye Publishing, LLC.

10. Seidel, G. (2002). Using the Law for Competitive Advantage (J-B-UMBS Series). Hoboken: Jossey-Bass.

11. Atepalykhin, A. (2017). Post Scriptum: Vyklyky yurydychnoho menedzhmentu chy trendy sohodennia? [Challenges of Legal Management or Current Trends?]. Ukrainskyi yuryst - Ukrainian Lawyer, 5. Retrieved from http://jurist.ua/?article/1319 (in Ukrainian).

12. Shevchenko, L. S., Makukha, S. M., Marchenko, O. S., Vovk, I. A., Ovsiienko, O. V., \& Chupryna, O. O. (2014). Yurydychna firma: poshuk modeli efektyvnoho menedzhmentu [Law Firm: Search for a Model of Effective Management]. Kharkiv: Pravo (in Ukrainian). 
13. Shevchenko, L. S., Makukha, S. M., Marchenko, O. S., Vovk, I. A., \& Ovsiienko, O. V. (2013). Menedzhment yurydychnoi firmy: konspekt lektsii [Man-agement of a Law Firm: Lecture Notes]. Kharkiv: NU "Yurydychna akad. Ukrainy imeni Yaroslava Mudroho". Retrieved from http://dspace.nlu.edu.ua/ bitstream/123456789/1718/1/Pr_39.pdf (in Ukrainian).

14. Marchenko, O. S., \& Yarmak, O. V. (2016). Yurydychnyi konsaltynh: sutnist ta rol u pravovii ekonomitsi [Legal Consulting: Essence and Role in the Legal Economy]. Kharkiv: FOP Danylko N.S. (in Ukrainian).

15. Marchenko, O. S. (2007). Rynok posluh yurydychnoho konsaltynhu v umovakh innovatsiinoho rozvytku ekonomiky [The Market of Legal Consulting Services in the Conditions of Innovative Development of the Economy]. Kharkiv: Kortes-2001 (in Ukrainian).

16. Permyakov, Yu. E. (2014). Pravovyie strategii kak kommunikativnyie modeli: problema opisaniya [Legal Strategies as Communicative Models: the Problem of Description]. Pravovedeniye - Jurisprudence, 5 (316), 73-80 (in Russian).

17. Mironov A. N. Yuridicheskaya strategiya v pravotvorcheskoy deyatelnosti [Legal strategy in law-making activities]. Retrieved from https://iteam.ru/ publications/legal/section_102/article_4255 (in Russian).

18. Legal management. From Wikipedia, the free encyclopedia. Retrieved from https://en.wikipedia.org/wiki/Legal_management.

19. Lakhuti, N. (2013, October 12-18). Portret yurysta [Portrait of a Lawyer]. Zakon i biznes - Law and Business, 41(1131). Retrieved from http://zib.com.ua/ua/ print/42815-portret_suchasnogo_yurista_rozumie_tehnichniy_bik_spravi_spr.html (in Ukrainian).

20. Ohliad rynku yurydychnykh posluh Ukrainy [Overview of the legal ser-vices market in Ukraine] (2016). Retrieved from http://www.kuluar.com.ua/2016/03/31/ ohlyad-rynku-yurydychnyh-posluh-ukrajiny (in Ukrainian).

21. Kane, S. (2010, April 10). Legal Management Associations. Retrieved from https://www.thebalance.com/legal-management-associations-2164614.

22. Kravchenko, A. (2016). Yuristy i IT-tehnologii: otchet o provedenii v Kieve I Mejdunarodnoy konferentsii yuridicheskih innovatsiy LEGAL TECH KYIV 2016 [Lawyers and IT-technologies: report on the holding of the 1st International Conference of Legal Innovations in Kyiv LEGAL TECH KYIV 2016]. Retrieved from http://bca.education/yuristy-i-it-tehnologii-otchet-o-provedenii-v-kievei-mezhdunarodnoj-konferentsii-yuridicheskih-innovatsij-legal-tech-kyiv-2016/ (in Russian).

23. Chepurko, V. (2017, April 28). Kak stat finansovym detektivom [How to become a financial detective]. KP Ukraina - KP Ukraine, 76, 7 (in Russian). 
Izdevniecība "Baltija Publishing"

Valdeķu iela 62 - 156, Rīga, LV-1058

Iespiests tipogrāfijā SIA "Izdevniecība "Baltija Publishing"

Parakstīts iespiešanai: 2018. gada 29. Aprīlis

Tirāža 300 eks. 